\title{
RESEDIMENTATION OF THE LATE HOLOCENE WHITE RIVER ASH, YUKON TERRITORY, CANADA AND ALASKA, USA
}

\author{
by Kim D. West
}

\author{
A thesis submitted to \\ The Faculty of Graduate Studies and Research \\ in partial fulfillment of \\ the requirements for the degree of
}

Doctor of Philosophy

Department of Earth Sciences

Carleton University

Ottawa, Ontario

May 16, 2007

(C) 2007, Kim D. West 


$\begin{array}{ll}\begin{array}{l}\text { Library and } \\ \text { Archives Canada }\end{array} & \begin{array}{l}\text { Bibliothèque et } \\ \text { Archives Canada }\end{array} \\ \begin{array}{l}\text { Published Heritage } \\ \text { Branch }\end{array} & \begin{array}{l}\text { Direction du } \\ \text { Patrimoine de l'édition }\end{array} \\ \begin{array}{l}\text { 395 Wellington Street } \\ \text { Ottawa ON K1A ON4 }\end{array} & \begin{array}{l}\text { 395, rue Wellington } \\ \text { Ottawa ON K1A ON4 } \\ \text { Canada }\end{array}\end{array}$

Your file Votre référence ISBN: 978-0-494-33516-1 Our file Notre référence ISBN: 978-0-494-33516-1

NOTICE:

The author has granted a nonexclusive license allowing Library and Archives Canada to reproduce, publish, archive, preserve, conserve, communicate to the public by telecommunication or on the Internet, loan, distribute and sell theses worldwide, for commercial or noncommercial purposes, in microform, paper, electronic and/or any other formats.

The author retains copyright ownership and moral rights in this thesis. Neither the thesis nor substantial extracts from it may be printed or otherwise reproduced without the author's permission.
AVIS:

L'auteur a accordé une licence non exclusive permettant à la Bibliothèque et Archives Canada de reproduire, publier, archiver, sauvegarder, conserver, transmettre au public par télécommunication ou par l'Internet, prêter, distribuer et vendre des thèses partout dans le monde, à des fins commerciales ou autres, sur support microforme, papier, électronique et/ou autres formats.

L'auteur conserve la propriété du droit d'auteur et des droits moraux qui protège cette thèse. $\mathrm{Ni}$ la thèse ni des extraits substantiels de celle-ci ne doivent être imprimés ou autrement reproduits sans son autorisation.
In compliance with the Canadian

Privacy Act some supporting forms may have been removed from this thesis.

While these forms may be included in the document page count, their removal does not represent any loss of content from the thesis.
Conformément à la loi canadienne sur la protection de la vie privée, quelques formulaires secondaires ont été enlevés de cette thèse.

Bien que ces formulaires aient inclus dans la pagination, il n'y aura aucun contenu manquant.

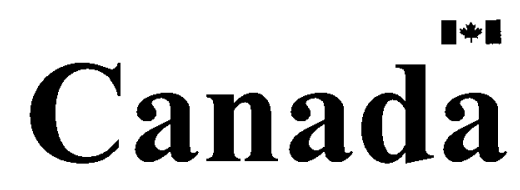




\begin{abstract}
The White River ash is one of the most distinct and widely dispersed pyroclastic deposits in Yukon-Alaska. It was produced from volcanic eruptions ca. 1887 (north lobe; Lerbekmo et al. 1975) and 1147 years B.P. (east lobe; Clague et al. 1995). The source of the deposit, Mount Churchill, is an ice-covered stratovolcano located $25 \mathrm{~km}$ west of the Yukon-Alaska border $\left(61^{\circ} 25^{\prime} \mathrm{N}, 141^{\circ} 70^{\prime} \mathrm{W}\right)$. Distal deposits of ash occur as primary airfall over much of Alaska, Yukon, and Northwest Territories. Locally resedimented deposits of ash are common closer to the volcanic source and occur in highly glaciated regions.
\end{abstract}

Distal deposits of White River ash provide important chronostratigraphic control and are used herein to interpret the cultural and environmental impact of ancient largemagnitude eruptions. Sedimentological observations of distal deposits of ash (preserved in fluvially deposited beds) indicates that emplacement of the east lobe of ash occurred during the late fall or early winter. Knowledge of the timing of the east lobe ash is significant to archaeological studies since deposition is associated with the massive migration and expansion of Athapaskan peoples.

ii 
Locally resedimented deposits of White River ash formed near Mount Churchill when hot volcanic material mixed with snow, ice, and volcanic debris at the summit and descended down surrounding valley glaciers. Large volumes of water and volcaniclastic sediment led to catastrophic thickening of the Russell and Klutlan Glaciers and possibly, temporary lakes from which terraces of ash, up to 20 metres thick, accumulated. Pyroclastic-rich fans formed downstream from resedimented material.

Eruptions of Mount Churchill are infrequent events that produce severe volcanic hazards, most notably ashfall and lahars. Future large-scale eruptions would significantly impact tourism, industry, housing and infrastructure and may devastate human and animal populations. Renewed efforts are urgently needed to advance geohazard mitigation in northern Canada and Alaska.

iii 


\section{Acknowledgements}

Several people have been instrumental in helping to complete this project. I want to thank my family and friends for their support, specifically, each of my parents, who inspired me to learn about so many things as a child. Without their love and encouragement of my rockhounding interests, I would not be where I am today. To my brother, for having confidence in me, and believing that I can do anything I put my mind to. To my husband, my best friend and soul mate, who made me laugh along the way, and Scout, who kept me company. I also want to thank all of the teachers who mentored me during my time working on this project.

There have been several colleagues at Carleton University and in Yukon Territory and Alaska whom I'd specifically like to thank. L. Ray and H. E rickson provided excellent assistance during several field seasons in Yukon Territory and Alaska; T. Glazier and H. Peterschein provided excellent guidance in the field. I'd also like to thank my supervisor, J.A. Donaldson, for believing in a Ph.D. student who loves to teach. Thanks also to B. Cousens, who provided assistance in some of the initial geochemical work that was undertaken.

T. Reinchardt provided assistance with some of the maps generated for this study. G. McGimsey provided comments and feedback on parts of the manuscript. This study would not have been completed without the logistical support provided by the Alaska

iv 
Volcano Observatory, and the generous assistance of G. McGimsey and D. Richter during the field season of 2003. During the course of this study, I was also supported in part by research grants from the Northern Scientific Training Program (1999-2001). 


\section{Table of Contents}

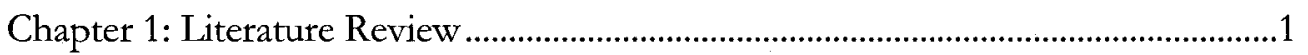

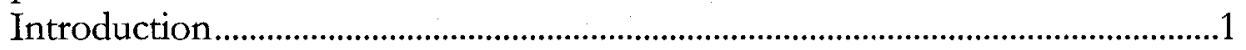

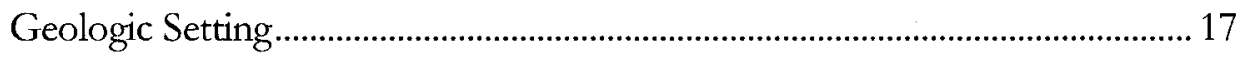

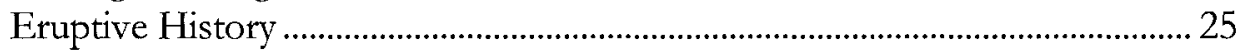

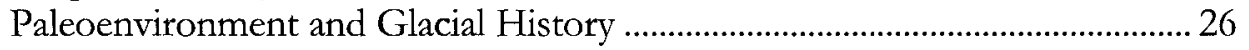

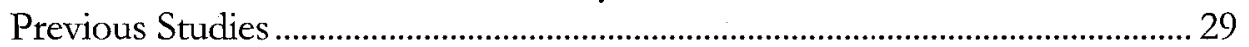

Chapter 2: Evidence for a Late Fall or Early Winter Emplacement

of East Lobe White River Ash .................................................................................. 40

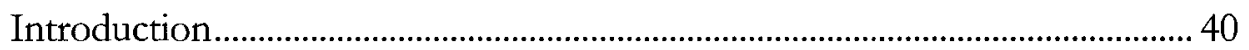

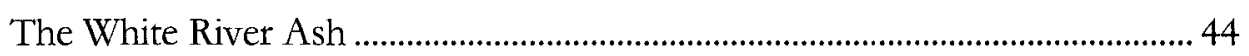

Evidence for Late Fall- Early Winter Emplacement ......................................... 53

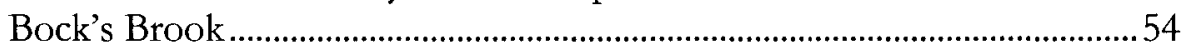

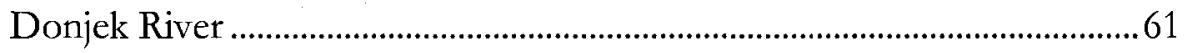

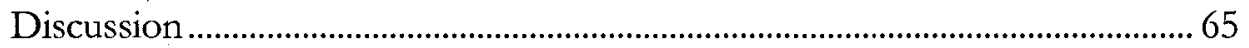

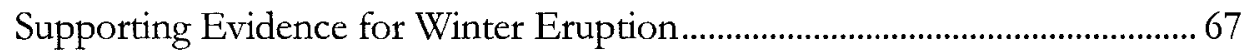

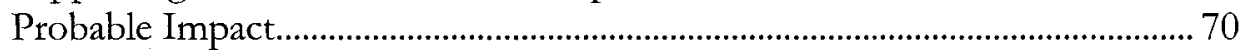

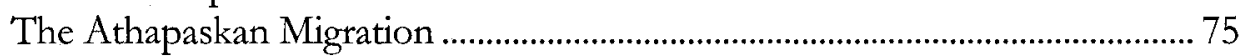

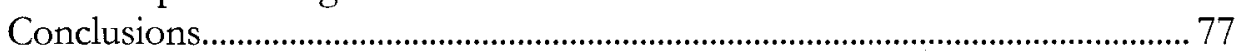

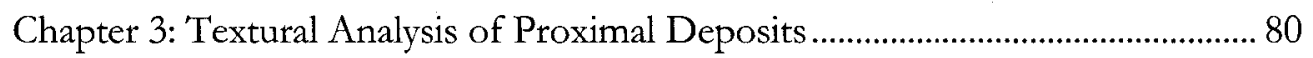

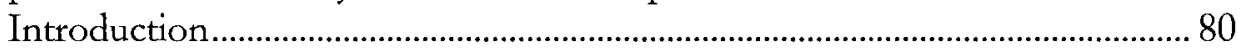

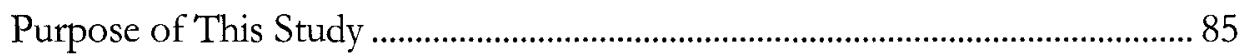

Sample Collection ................................................................................................ 85

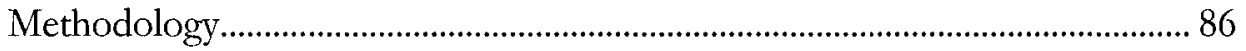

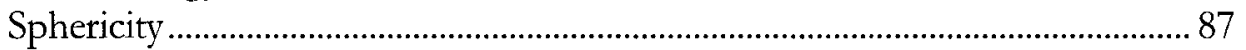

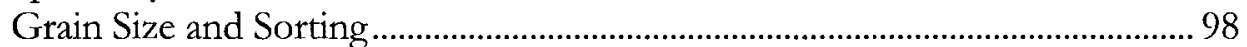

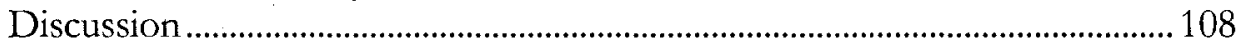

Chapter 4: Facies Analysis of Proximal Deposits.................................................. 111

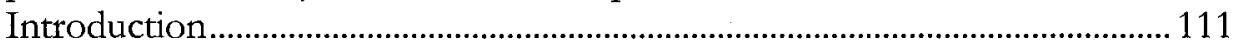

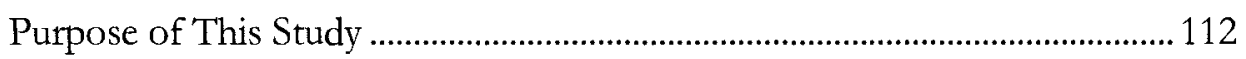

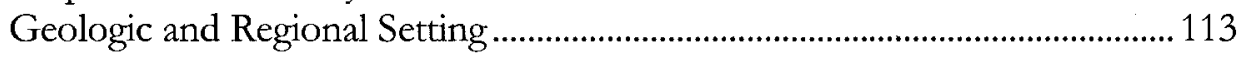

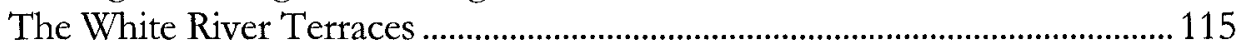

The White River Fan....................................................................................116

Terminology and Methodology …................................................................ 119

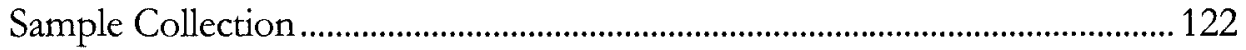

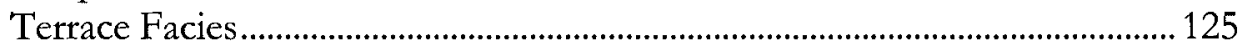

(1) Massive to Normal-Graded Vitric Cohesive Silt (S-1) ........................125

vi 
(2) Ripple Cross-Laminated and Horizontally-Laminated Ash (A-2) .....131

(3) Well-Sorted Ash (A-3) ...........................................................................134

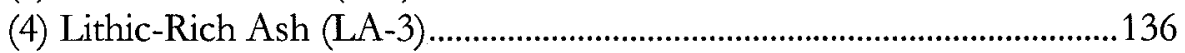

(5) Well-sorted Lapilli (L-3) ...........................................................................139

(6) Laminated, Ungraded to Inverse-Graded Ash (A-4) ...............................141

(7) Faintly Laminated, Normal-Graded Ash (A-5) ......................................142

(8) Grain-Supported, Normal-Graded Lapilli Ash (LA-5) ........................143

(9) Cross-Bedded Lapilli Ash (LA-6) .............................................................145

(10) Ungraded to Inverse-Graded Lapilli Ash (LA-7) .................................147

(11) Ungraded to Inverse-Graded Agglomerate (AG-7) ............................150

(12) Disorganized Lithic-rich Lapilli Ash (LA-8) .......................................151

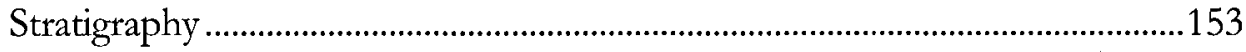

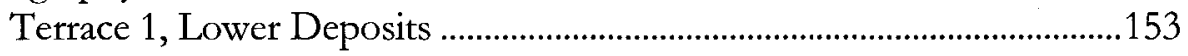

Terrace 1, Middle Deposits .............................................................................155

Terrace 1, Upper Deposits.........................................................................156

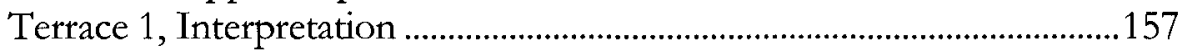

Terrace 2, Lower Deposits ........................................................................158

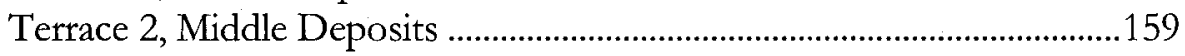

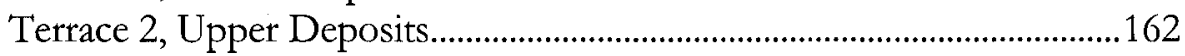

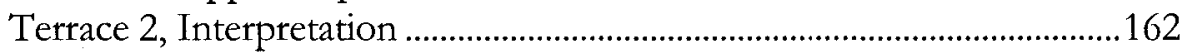

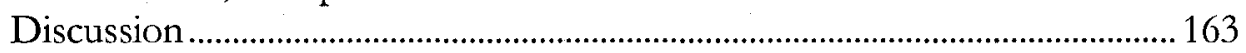

Volcaniclastic Fan Facies.............................................................................. 168

Other Considerations............................................................................................. 169

Chapter 5: Potential Hazards from Future Eruptions of

Mount Churchill, Alaska........................................................................................ 172

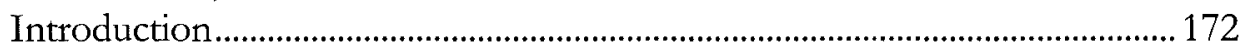

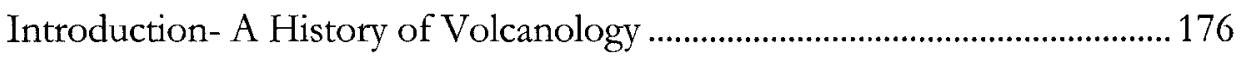

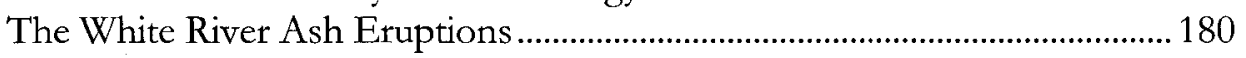

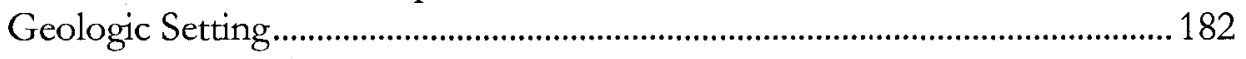

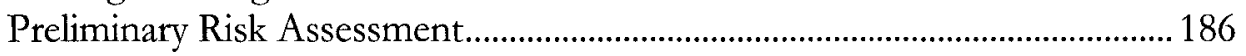

Potential Impacts of Volcanic Hazards ............................................................ 189

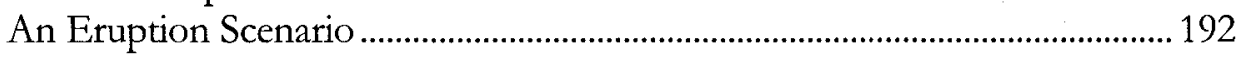

Tephra Fall ............................................................................................195

Aviation and Air Travel Concerns ...........................................................206

Lahars and Flooding ...........................................................................207

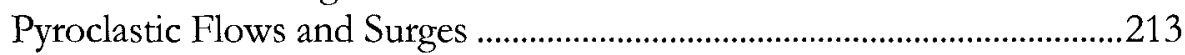

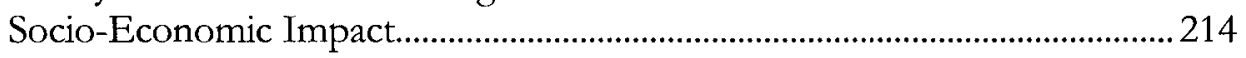

Affected Areas and Populations .............................................................214

Natural Resources, Trade, and Industry....................................................217

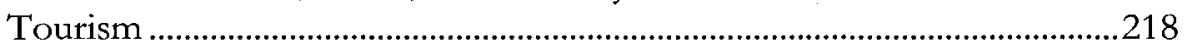

Impact on Yukon Economy .....................................................................219

Impact on Aviation Economies...................................................................220

vii 


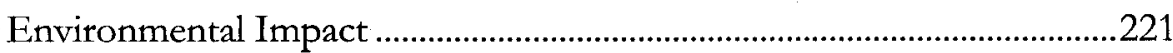

Ecological Impact in National Park Regions ..................................................... 223

Kluane National Park and Reserve, Yukon Territory ..................................223

Physiography ...............................................................................................224

Flora and Fauna ..........................................................................................225

Wrangell-St. Elias National Park and Preserve, Alaska..............................226

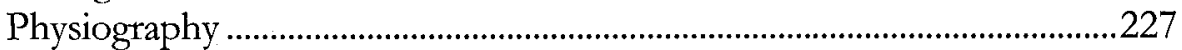

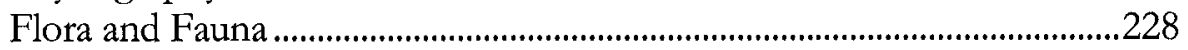

Biodiversity in the St. Elias Region ..........................................................231

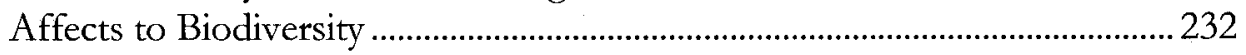

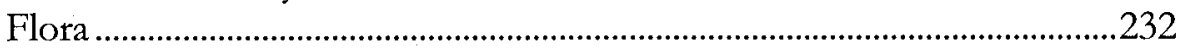

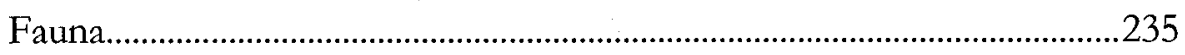

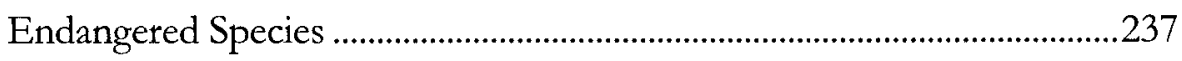

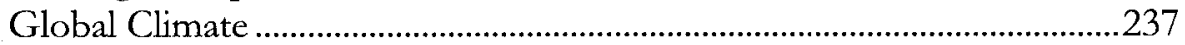

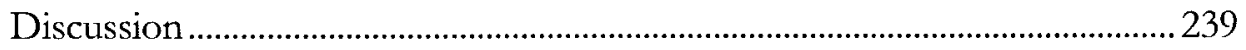

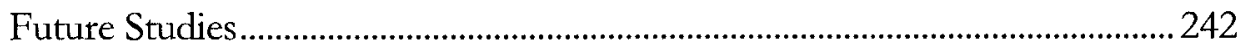

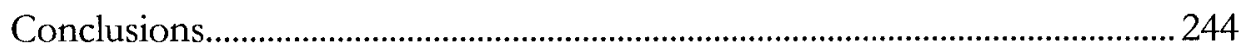

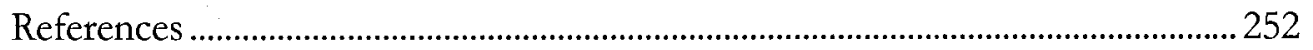




\section{List of Figures}

Figure

Page

1. Map of Yukon and Alaska, displaying extent and distribution of the

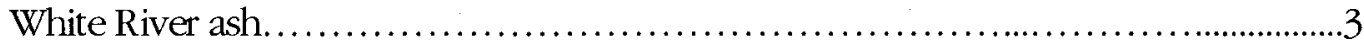

2. Source of the White River ash, the Bona-Churchill complex...........................4

3. Long tube vesicles from the east and north lobes of White River ash.............8

4. Distal deposits of east and north lobe White River ash..................................10

5. Proximal deposits of White River ash near Mount Natazhat........................11

6. Proximal tephra displaying various degrees of angularity ...........................12

7. Resedimented terrace of proximal White River ash and pumice....................13

8. Rounded White River lapilli in a volcaniclastic fan...............................14

9. Kluane, Wrangell-St. Elias National Park and surrounding regional

protected areas.......................................................... 16

10. Range in size and thickness of distal deposits of White River ash .................18

11. Distal deposits of ash along roadsides and riverbanks in Yukon Territory........41

12. The White River ash as a chronostratigraphic marker.........................45

13. Maximum thickness of east lobe White River ash, near Koidern, Yukon..........47

14. Irregular upper gradational contact in distal White River ash.....................49

15. Charcoal seams in distal White River ash...................................51

16. Resedimented deposits of distal White River ash...........................552

17. Map of Bock's Brook and Donjek River sites................................55

18. Overview of the ash layer at Bock's Brook....................................56

19. Gravel layer directly above ash layer at Bock's Brook........................58

20. Stratigraphic section at Bock's Brook.......................................59

21. Gravel-filled scour evident in ash layer at Bock's Brook ......................60

22. Overview of the ash clasts at Donjek River..............................62

23. Stratigraphic section at Donjek River ..................................63

24. Close-up of angular ice-cemented ash clasts at Donjek River...................64

25. Multiple airfall layers preserved along the Alaska Highway................... 71

26. Locally resedimented terraces along the margins of Klutlan Glacier.............83

27. Map of samples selected for textural analysis.............................88

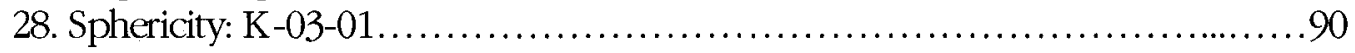

29. Sphericity: K-5f-01.............................................91

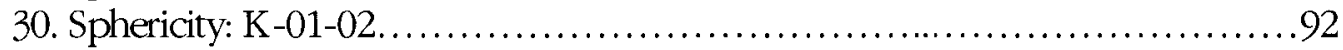

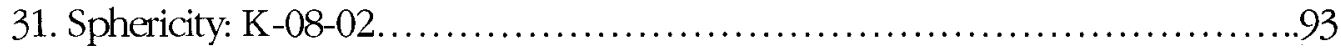

32. Sphericity: K-10-02 ..............................................94

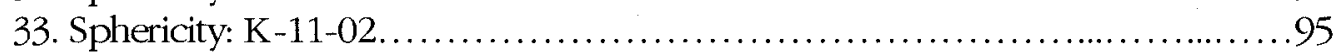

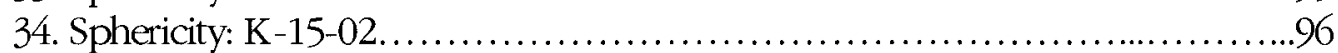

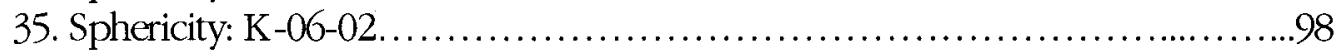

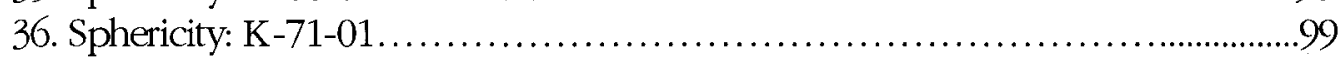

37. Sphericity: K-62-01...........................................100

38. Size distribution of samples collected ................................ 102

ix 
39. Cumulative weight curve of samples collected........................103

40. Medium-grained ash with silt interlayers, near Russell Glacier..............104

41. Airfall ash collected from the top of a 22 metre thick terrace...............106

42. Overview of volcaniclastic fan......................................117

43. Vertical section of pyroclastic fan.................................118

44. Proximal terrace deposit on the south side of Klutlan

Glacier (Terrace 1) .............................................. 120

45. Proximal terrace deposit on the north side of the Klutlan

Glacier (Terrace 2) ................................................. 121

46. Granulometric classification of White River ash deposits.....................123

47. Thickness of units as defined by Ingram (1954) ......................124

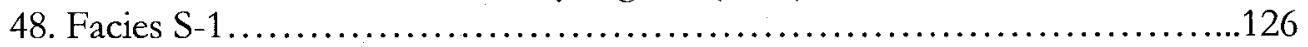

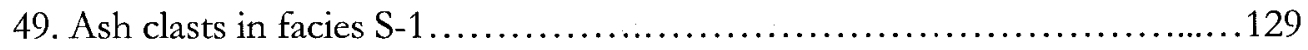

50. Internally laminated ash clast from proximal

terrace along Klutlan Glacier..............................................130

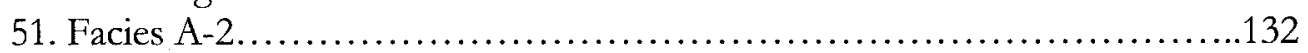

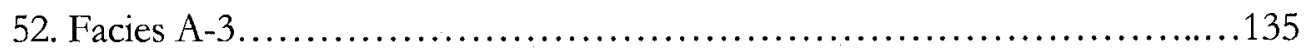

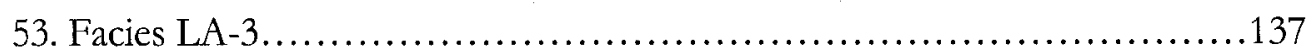

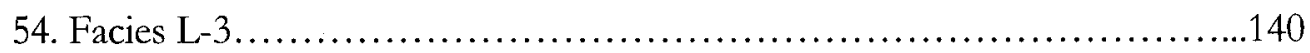

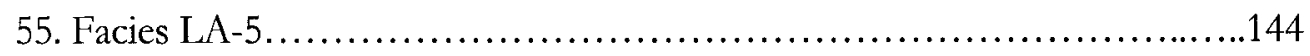

56. Facies LA-6.......................................................

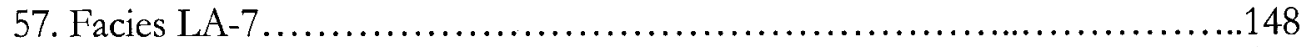

58. Facies AG-7 ................................................ 151

59. Stratigraphy of Terrace 1, south side of Klutlan Glacier....................154

60. Stratigraphy of Terrace 2, north side of Klutlan Glacier.....................160

61. Stratigraphy of Terrace 2, north side of Klutlan Glacier....................161

62. Airfall ash layer capping proximal terraces............................ 164

63. Pumice along the banks of the White River, near the Alaska Highway........182

64. Hazard map for Mount Churchill region...............................193 


\section{List of Tables}

Number

Page

1. World's most famous historic eruptions.

.6

2. Chemical composition of the White River ash...............................7

3. Characteristics of eruptive centres in the

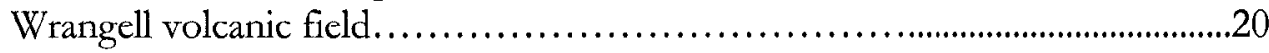

4. Terrace facies and interpretations................................. 127

5. Major potential hazards associated with future

eruptions of Mount Churchill............................................194

6. Population statistics, Yukon Territory, Canada and Alaska, U.S.A.. .........199

7. Communities most at risk from future eruptions of Mount Churchill..........201

8. Endangered, threatened, special concern, and potentially at risk species in Yukon Territory.........................................238 


\section{Chapter 1: Literature Review}

\section{Introduction}

In the past few decades, the study of volcaniclastic rocks has greatly contributed to our understanding of volcanic processes and eruptions. The study of volcaniclastic rocks provides the opportunity for interdisciplinary collaboration, merging the skills of petrologists, volcanologists, and sedimentologists. For example, the petrology of volcaniclastic deposits provides critical information on the composition, zoning, and character of magma chambers, on the internal plumbing systems and release mechanisms of magma chambers, and on mixing and output rates (Walker 1981). In addition, the eruptive history, including the style, frequency, geochemistry, and magnitude of eruptive events may be deduced from volcaniclastic deposits. These characteristics can provide a basis for assessing future volcanic behavior, and are particularly important when estimating hazards associated with future eruptions (Begét and Nye 1994). The distribution, grain size characteristics, and sedimentary structures of volcaniclastic deposits may also reflect processes of resedimentation, including the fragmentation, transport and dynamics of explosive eruptions (Gardner 1993). Volcaniclastic deposits have also been used in chronological studies as marker horizons, as measures of infill in sedimentary basins or alluvial fans, and in tectonic studies. Although volcaniclastic deposits have received increased attention in recent years, there still is a paucity of studies that document and interpret physical processes, and the relationships among volcaniclastic deposits (Cas and Wright 1987). This thesis helps to fill this void by addressing 
the physical parameters and depositional settings of volcaniclastic sediments, using the White River ash of Arctic North America as an example.

The White River ash is one of the most distinct and widely dispersed primary fall deposits $\left(540,000 \mathrm{~km}^{2}\right.$; Robinson 2001) in the Yukon-Alaska region. It is preserved in two elongate lobes (east and north) related to prevailing wind directions during two distinct explosive eruptions ca. 1887 years B.P. (north lobe; Lerbekmo et al. 1975) and 1147 years B.P. (east lobe; Clague et al. 1995; Figure 1). Recent work by Jensen and Froese (2006) has expanded the distribution of the White River deposits, suggesting that the northern lobe of ash covered approximately $100,000 \mathrm{~km}^{2}$ and the eastern lobe covered approximately $500,000 \mathrm{~km}^{2}$. The

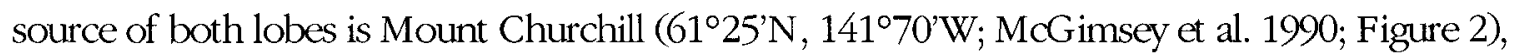
which is one of the few volcanoes that have been active in the Wrangell volcanic field of Yukon-Alaska during the Holocene. The youngest eruption of White River ash is associated with high sulphate peaks around 703 A.D. in the Greenland (GISP2) ice core (Zielinski 1995).

The White River deposit has an estimated bulk volume of $25-50 \mathrm{~km}^{3}$, with the east lobe containing the greater volume of ash (15-30 km³; Berger 1960; Bostock 1952). Based on the recent discovery of thin layers of ash at least $1300 \mathrm{~km}$ east of the vent (Robinson 2001), the volume of eruptive materials (25-50 km³; Bostock 1952; Berger 1960), and the new distribution estimates from Jensen and Froese (2006), it can safely be said that the White River eruptions are comparable in magnitude and size to some of the largest eruptions in history, including the 


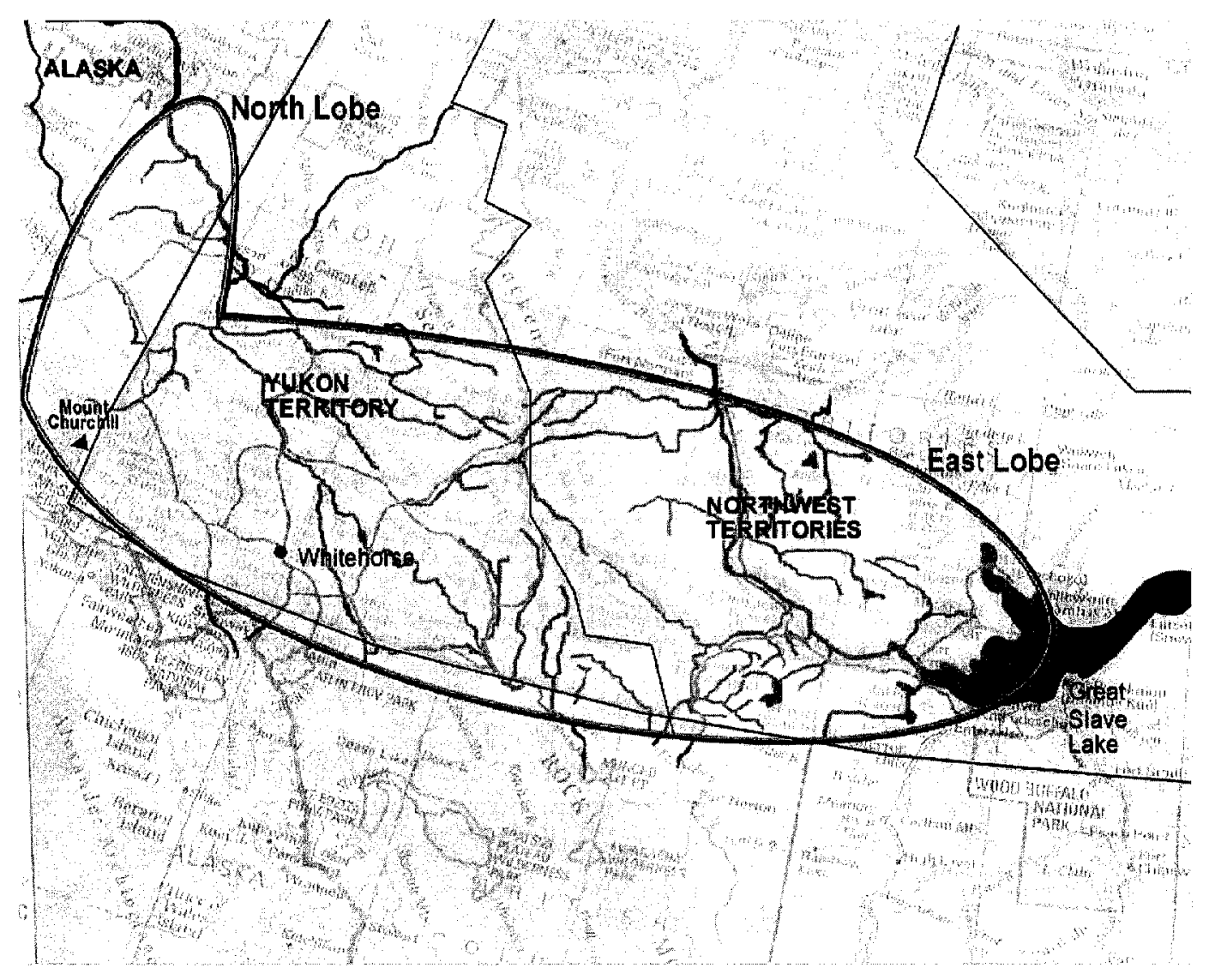

Figure 1: Map of Yukon Territory, and Alaska, USA, displaying the extent and distribution of the eruptions of White River ash ca. 1887 (northern; Lerbekmo et al. 1975 ) and 1147 years ago (eastern lobe; Clague et al. 1995). Modified after Robinson (2001). The base map is published annually by the American Automobile Association (1999). 


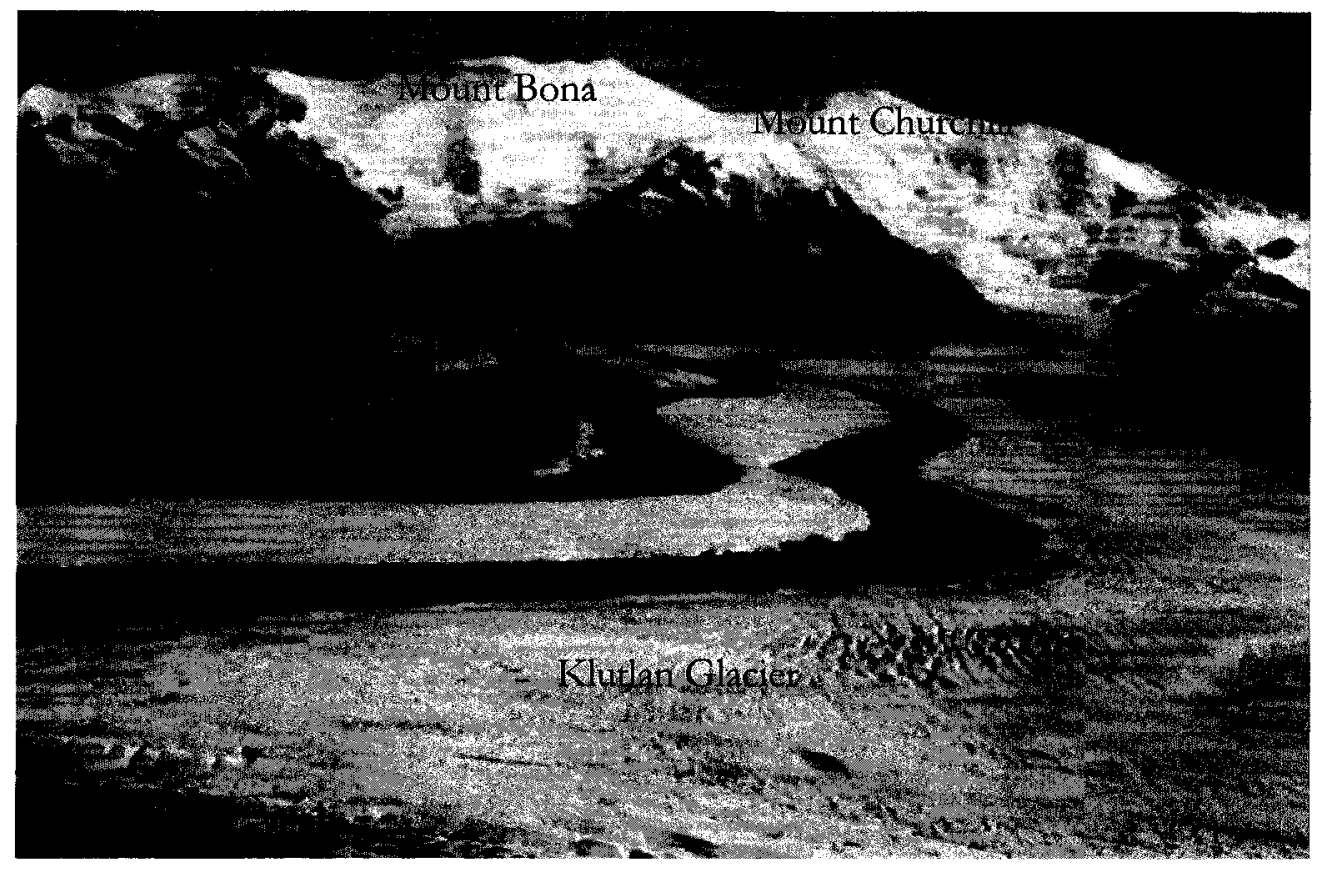

Figure 2: Source of the White River ash, the Bona-Churchill complex. This is a view looking west, with Mount Bona on the left $(5,005 \mathrm{~m} ; 16,421 \mathrm{ft})$ and Mount Churchill on the right $(4,766 \mathrm{~m} ; 15,636 \mathrm{ft})$. Klutlan Glacier is in the foreground. 
1883 eruption of Krakatau, Indonesia, and the 1912 eruption of Katmai, Alaska (Downes 1979; Table 1).

Radiocarbon dating, based on numerous peat and wood samples at several sites distal and proximal to the vent, indicates that the north lobe ash was deposited ca. 1887 years B.P. (Lerbekmo et al. 1975). A radiocarbon estimate for the east lobe ash (ca. 1147 years B.P.) is based on a sample taken from a stump killed in growth position during the latest eruption (Clague et al. 1995). Recent work by Jensen and Froese (2006) also suggests that the north lobe was deposited between 150-500 AD (based on dating of floodplain exposures along the Yukon River) and the east lobe at approximately $800 \mathrm{AD}$. Deposition of east lobe ash took place in response to prevailing winds from the west; the north lobe was deposited by prevailing winds from the south (Figure 1). Based on present-day wind patterns in Yukon and Alaska, the north lobe ash may have been deposited during the summer and the east lobe ash during the winter (Hanson 1965). Stratigraphic evidence presented in Chapter 2 indicates that the younger lobe of ash was deposited during the late fall or early winter.

The White River ash is primarily composed of glass, plagioclase, hornblende, hypersthene, and magnetite (Lerbekmo and Campbell 1969) with minor amounts of biotite (Table 2) and is highly vesicular (Figure 3). Secondary resedimented ash occurs near the source, whereas 


\begin{tabular}{|c|c|c|c|c|c|}
\hline Name & Location & Date & $\begin{array}{l}\text { Volume } \\
\left(\mathrm{km}^{3}\right)\end{array}$ & VEI & ${ }^{1}$ Fatalities \\
\hline Tambora & Indonesia & 1815 & $T: 160$ & 7 & 60,000 \\
\hline Taupo & New Zealand & 180 & $T: 65-105$ & $6+$ & - \\
\hline Novarupta & U.S.A. & 1912 & $\begin{array}{l}T: 24-32 ; L: \\
0.01\end{array}$ & 6 & 2 \\
\hline $\begin{array}{l}\text { Bona- } \\
\text { Churchill }\end{array}$ & U.S.A. & $\begin{array}{l}1200 \mathrm{yr} \\
\text { B.P. }\end{array}$ & ${ }^{2} T: 27 / 25$ & 6 & - \\
\hline Krakatau & Indonesia & 1883 & $T: 18-22$ & 6 & 36,417 \\
\hline $\begin{array}{l}\text { Bona- } \\
\text { Churchill }\end{array}$ & U.S.A. & & ${ }^{3} T: 20$ & 6 & - \\
\hline Santa Maria & Guatemala & 1902 & $T: 12$ & 6 & $>5,000$ \\
\hline Pinatubo & Philippines & 1991 & $T: 8.5-10.3$ & $5+$ & $>740$ \\
\hline $\begin{array}{l}\text { Quizapa } \\
\text { (Azul) }\end{array}$ & Chile & 1932 & $T: 9.5$ & $5+$ & 0 \\
\hline Hudson & Chile & 1991 & $T: 7.6$ & $5+$ & 0 \\
\hline $\begin{array}{l}\text { Somma- } \\
\text { Vesurvius }\end{array}$ & Italy & 79 A.D. & $T: 2.8-3.8$ & 5 & 3,360 \\
\hline El Chichon & México & 1982 & $T: 2.5$ & 5 & $>2,000$ \\
\hline Tarawera & New Zealand & 1886 & $T: 2$ & 5 & 153 \\
\hline St. Helen's & U.S.A. & 1980 & $\begin{array}{l}T: 1.2 \\
L: 0.074 \\
\end{array}$ & 5 & 57 \\
\hline Pelée & West Indies & 1902 & $\begin{array}{l}T:>0.2 \\
L:>0.1\end{array}$ & 4 & ${ }^{4} 29,000$ \\
\hline $\begin{array}{l}\text { Nevado del } \\
\text { Ruiz }\end{array}$ & Colombia & 1985 & ${ }^{5} T: 0.03$ & 3 & 623,080 \\
\hline
\end{tabular}

Table 1: World's most famous historic eruptions, compared to the east and north lobe eruptions of White River ash. $T$ refers to total volume of tephra erupted; $L$ refers to total volume of lava erupted. Data compiled from Venzke et al. (2002-) with the exception of ${ }^{1}$ Simkin and Siebert (2000); ${ }^{2}$ Robinson (2001); ${ }^{3}$ Robinson (2001); ${ }^{4}$ Tanguy (1994); ${ }^{5}$ Pierson et al. (1990) and ${ }^{6}$ Melson et al. (1990). 


\begin{tabular}{|c|c|c|c|c|c|}
\hline & $\begin{array}{l}\text { Dacite } \\
\text { Pumice } \\
\text { Lapillus, } \\
\text { Mt } \\
\text { Churchill } \\
\text { (McGimsey } \\
\text { et al. 1992) }\end{array}$ & $\begin{array}{l}\text { Mean of } 66 \\
\text { samples, } \\
\text { WRA } \\
\text { (Lerbekmo } \\
\text { and } \\
\text { Campbell, } \\
\text { 1969) }\end{array}$ & $\begin{array}{l}\text { Distal } \\
\text { Northem- } \\
\text { Lobe WRA } \\
\text { (Domaldson } \\
\text { et al. 1996) }\end{array}$ & $\begin{array}{l}\text { Distal } \\
\text { Eastem- } \\
\text { Lobe WRA } \\
\text { (Domaldson } \\
\text { et al. 1996) }\end{array}$ & $\begin{array}{l}\text { Mean of } 3 \\
\text { samples, } \\
\text { Klutlan } \\
\text { Glacier } \\
\text { (Donaldson } \\
\text { et al. 1996) }\end{array}$ \\
\hline $\begin{array}{l}\mathrm{SiO}_{2} \text { (wt. } \\
\%)\end{array}$ & 66.10 & 67.40 & 66.33 & 63.04 & 65.90 \\
\hline $\mathrm{TiO}_{2}$ & 0.42 & 0.50 & 0.37 & 0.35 & 0.42 \\
\hline $\mathrm{Al}_{2} \mathrm{O}_{3}$ & 16.20 & 15.10 & 14.67 & 18.08 & 15.58 \\
\hline $\mathrm{Fe}_{2} \mathrm{O}_{3}$ & 2.95 & 4.20 & 2.78 & 2.78 & 3.35 \\
\hline MnO & 0.05 & - & 0.06 & 0.05 & 0.06 \\
\hline MgO & 1.36 & 2.00 & 0.86 & 1.24 & 1.43 \\
\hline $\mathrm{CaO}$ & 4.18 & 4.10 & 2.95 & 5.22 & 3.96 \\
\hline $\mathrm{Na}_{2} \mathrm{O}$ & 4.16 & 4.10 & 4.03 & 4.32 & 4.03 \\
\hline $\mathbf{K}_{2} \mathbf{O}$ & 2.51 & 2.50 & 2.71 & 1.96 & 2.45 \\
\hline $\mathbf{P}_{2} \mathbf{O}_{5}$ & 0.14 & - & 0.12 & 0.10 & 0.13 \\
\hline $\mathrm{CO}_{2}$ & 0.04 & - & - & - & - \\
\hline Total & 98.73 & 99.99 & 95.09 & 97.39 & 97.53 \\
\hline $\begin{array}{l}\mathbf{R b} \\
\text { (ppm) }\end{array}$ & - & 36 & 56 & 37 & 46 \\
\hline Sr & - & 771 & 575 & 1135 & 748 \\
\hline
\end{tabular}

Table 2: Chemical composition of proximal deposits of White River ash. Note the higher concentration of $\mathrm{SiO}_{2}$ in north lobe White River ash. Reprinted with permission from Donaldson et al. (1996). 


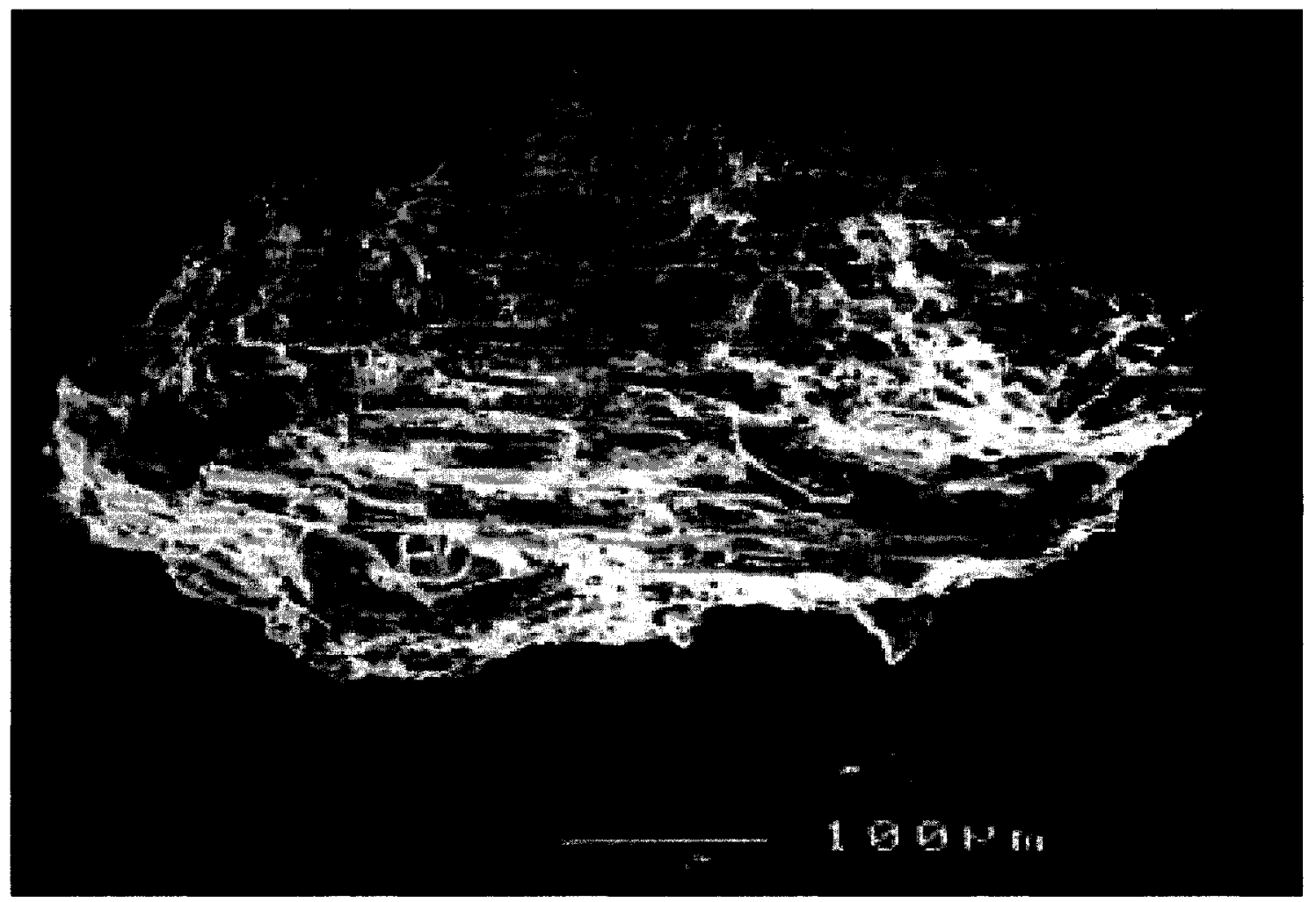

Figure 3: Long-tube vesicles are present in White River ash from the east and north lobes. Both eruptions were incredibly violent; each is classified with a VEI of 6 (Newhall and Self 1982). 
primary fall deposits are common in distal regions. Fall deposits range from 3 to $60 \mathrm{~cm}$ in thickness and decrease in size from granule to silt-sized particles with increased distance from Mount Churchill. Most distal deposits comprise moderately sorted angular to subround fragments of ash and pumice lapilli. In the zone of overlap, the east lobe ash $(0.125-0.25 \mathrm{~mm})$ is several centimeters above the finer-grained north lobe ash (0.25- $0.5 \mathrm{~mm}$; Figure 4). Differences in the Fe-Ti composition of hematite-ilmenite minerals in the north and east lobes are the most useful geochemical means for distinguishing between the ash deposits (Jensen and Froese 2007; Lerbekmo et al. 1975).

The White River ash occurs as coarse beds of pumice-rich material, up to $50 \mathrm{~m}$ in thickness, at the summit of Mount Churchill (McGimsey et al. 1990). Proximal deposits of lapilli and ash are approximately 0.6-1.5 m thick near the Klutlan and Natazhat glaciers (Rampton 1970; Figure 5). Most of these proximal deposits are reworked, displaying less angular grains and an improvement in sorting compared to their distal equivalents (Figure 6). In some places, resedimented terraces of ash and pumice occur along Klutlan Glacier for several kilometers (Figure 7). These terraces were deposited when hot volcanic material mobilized snow, ice, and volcanic debris at the summit of Mount Churchill, descending down well-defined valleys to the north, and contributing large volumes of volcaniclastic sediment in the Klutlan glacial valley to form terraces up to 20 metres thick (discussed in Chapters 3 and 4; Figure 8). In addition, 


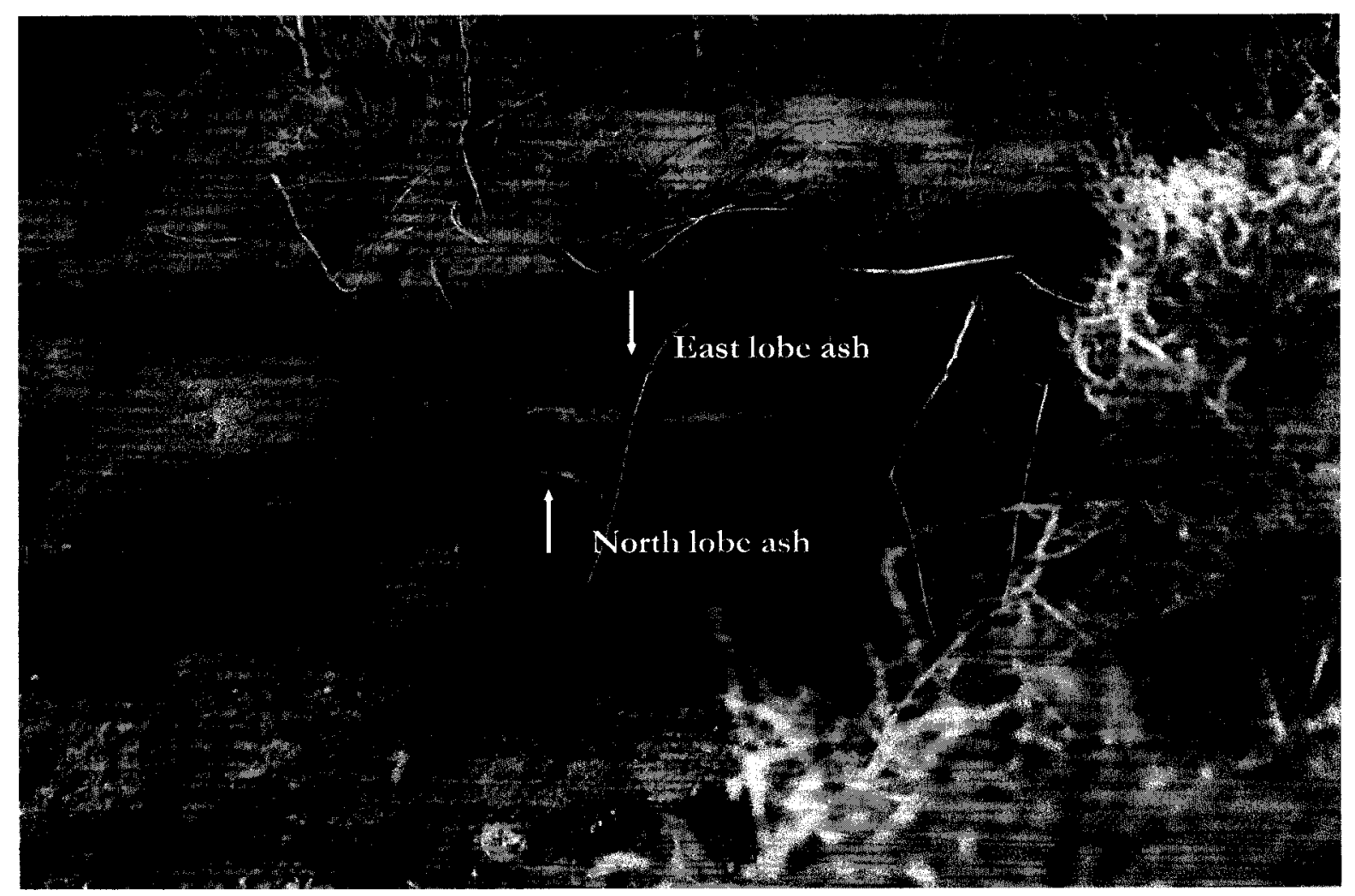

Figure 4: Distal deposits of east and north lobe ash located near the junction of Duke River with the Alaska Highway. The ash layers vary in thickness according to distance from Mount Churchill. Here, the east lobe ash is laterally continuous, thicker, and coarser-grained than the north lobe ash, which sits stratigraphically below. 


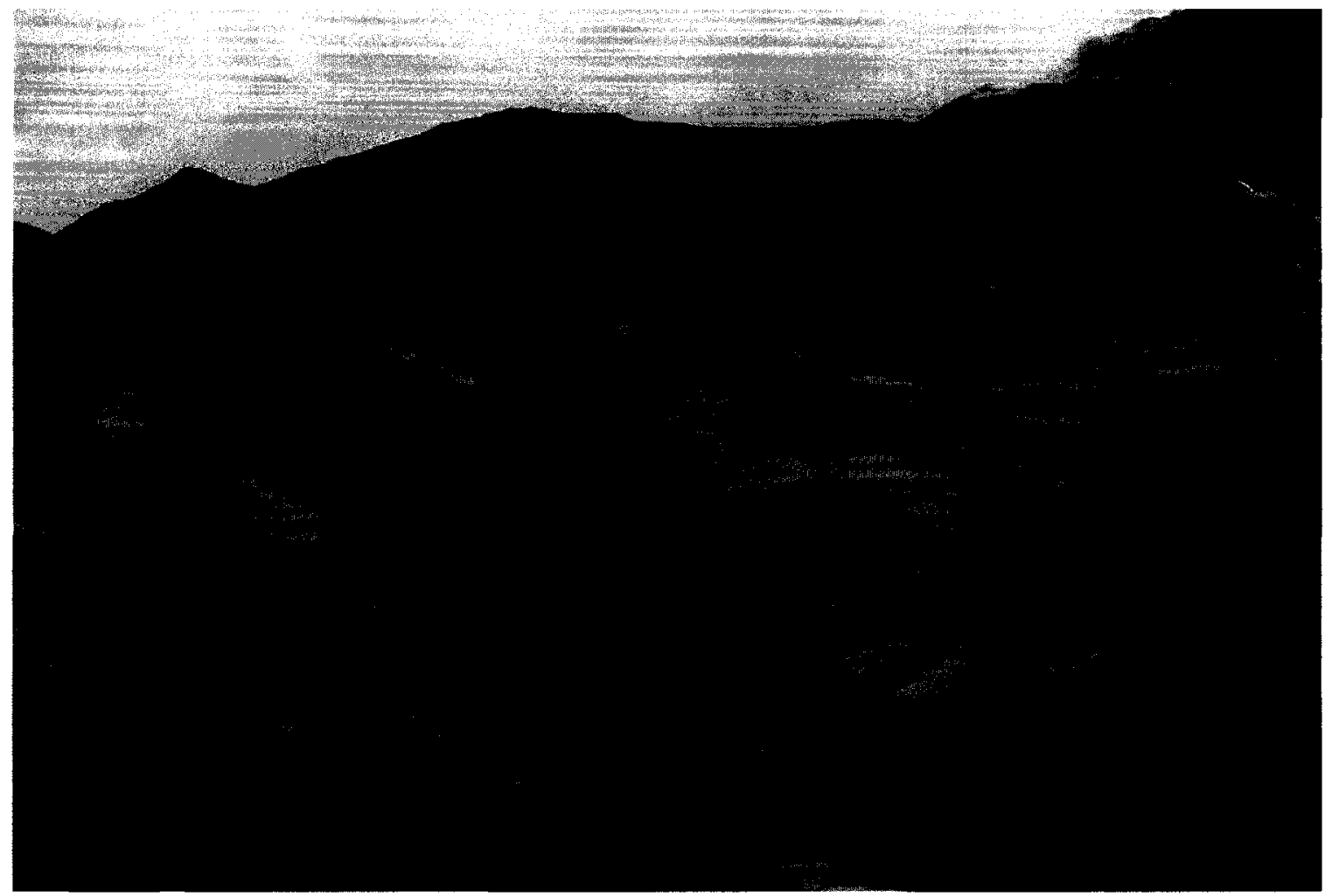

Figure 5: Proximal deposits of White River ash near Mount Natazhat. White areas depict ash, not snow. Deposits in this region are mostly reworked, and approximately $0.6-1.5 \mathrm{~m}$ thick (Rampton 1970). 


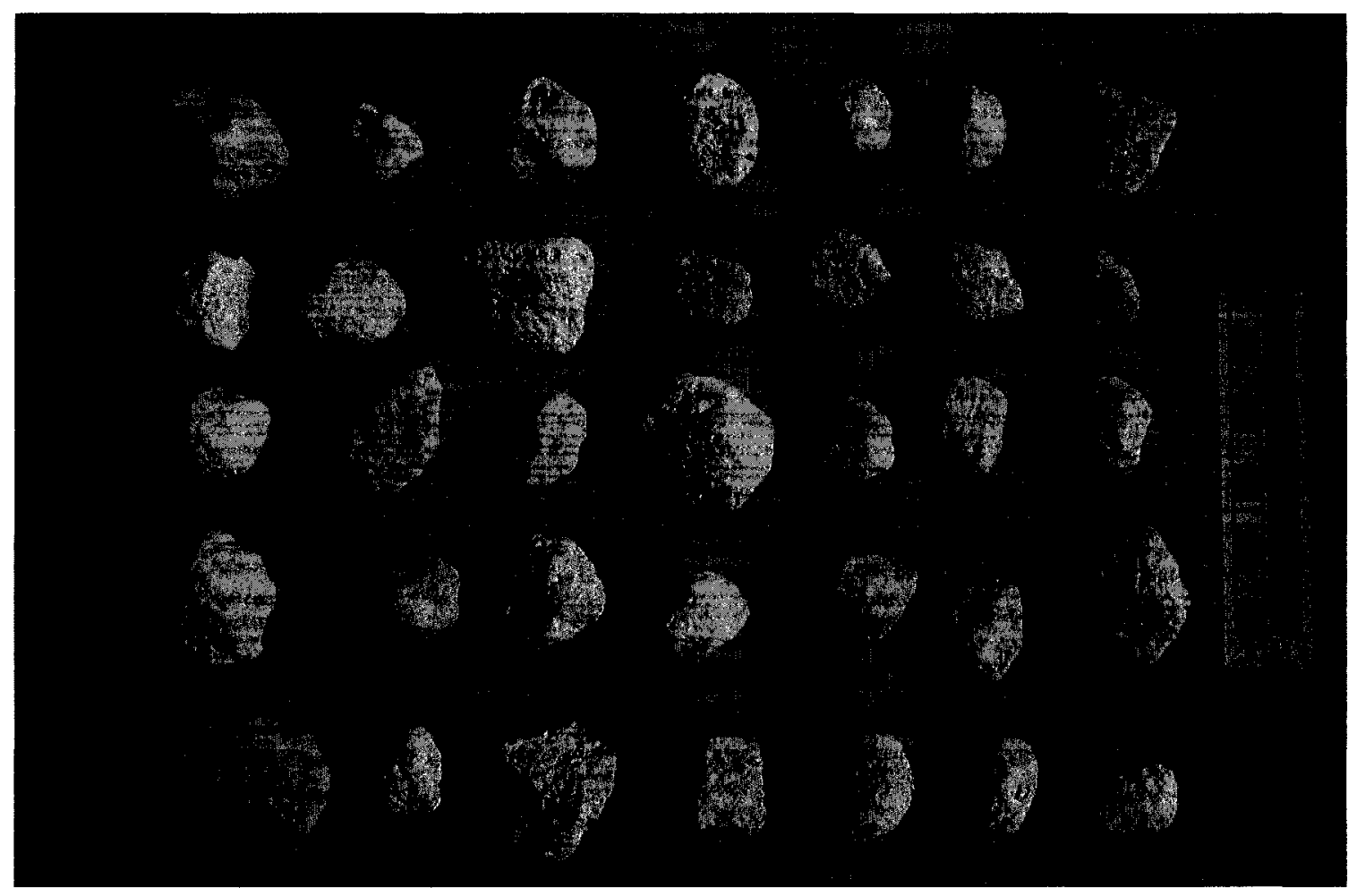

Figure 6: Samples of proximal White River lapilli displaying various degrees of angularity. 
Figure 7: Resedimented terrace of White River ash and lapilli, along the Klutlan glacial valley. Most terraces along the Klutlan" valley have steep $\left(>30^{\circ}\right)$ angle of repose margins and flat tops. This terrace is nearly $20 \mathrm{~m}$ in thickness and is composed of interlayers of ash and lapilli along with clay that formed when hot pyroclastic debris from eruptions of Mount Churchill mixed with snow and ice, forming floods along the Klutlan glacial valley. View looking north. 


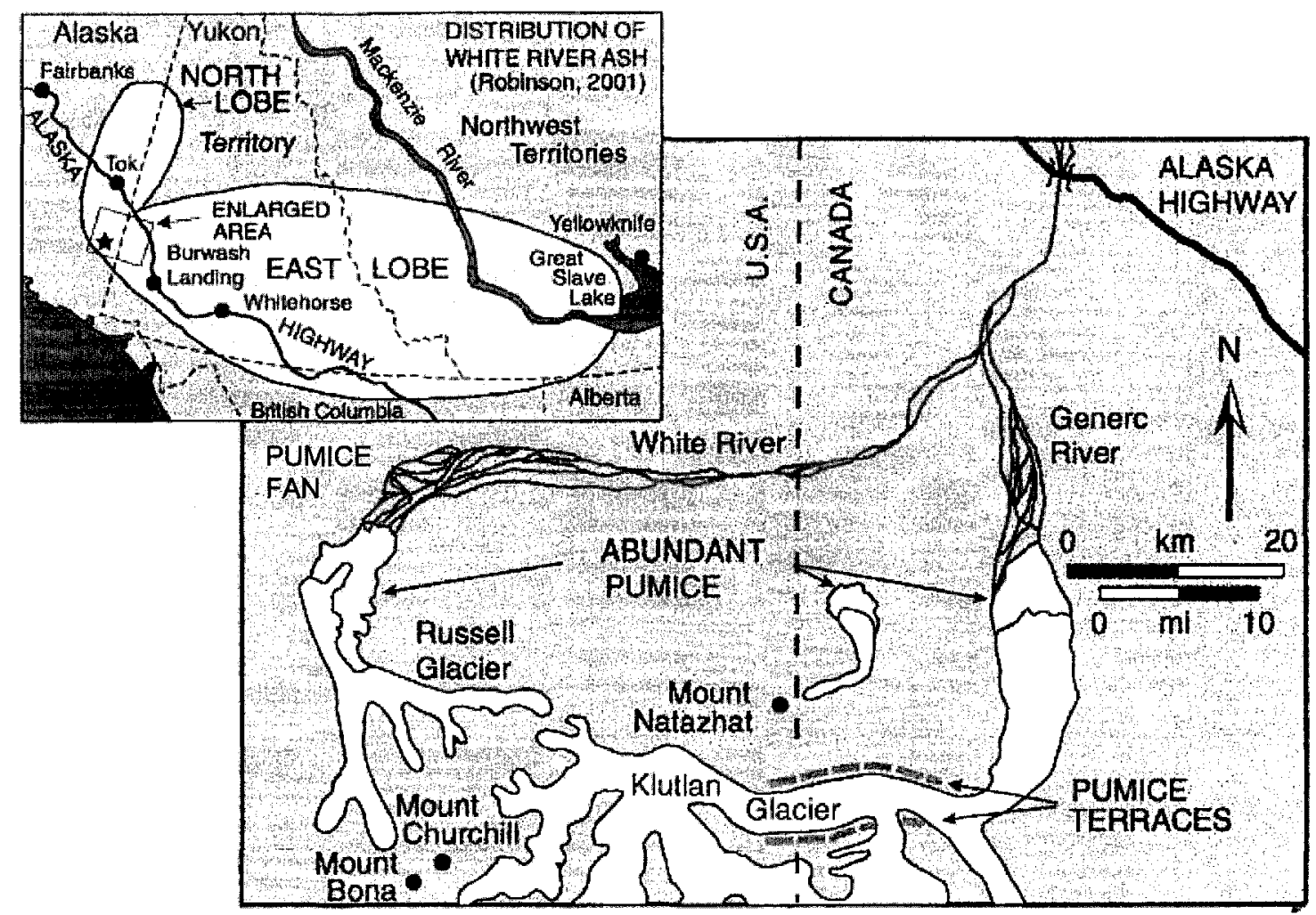

Figure 8: Distribution of proximal White River ash, and location of terrace and fan deposits. The upper inset displays the regional distribution of distal deposits of White River ash (after Robinson 2001). 
mountainous terrain on both sides of this valley was inundated with ash and volcaniclastic debris, providing the source of subsequently formed pumice-rich fans more than $35 \mathrm{~km}$ east of the vent (Figure 9). Geochemical analyses indicate that ash and lapilli from proximal terrace deposits are similar in composition to distal deposits of White River ash (Donaldson et al. 1996; Table 2).

Farther from the volcano, the east lobe ash is more widely dispersed, suggesting that the younger White River eruption (ca. 1147 years B.P.; Clague et al. 1995) was more violent than its predecessor ca. 1887 years B.P. (Lerbekmo et al. 1975). A higher temperature estimate for the east lobe magma $\left(995-1030^{\circ}\right.$ Celsius) than for north lobe magma $\left(950-990^{\circ}\right.$ Celsius) fits with this observation (Downes 1985). However, according to Siebert and Simkin (2002-), the north and east lobe eruptions are classified with a VEI of 6 (Newhall and Self 1982; Table 1). The VEI index, based on a combination of known characteristics, takes into account the historical description of the eruption (non-explosive to very large), the volume of tephra, cloud column height, qualitative description (gentle to cataclysmic), as well as eruption type (Hawaiian to ultra-Plinian). The VEI scale represents a very broad categorization and therefore does not reflect subtle differences when comparing specific volcanic events such as the White River eruptions. Nonetheless, eruptions of VEI 6 are rare events, producing on average 39 to $100 \%$ fatalities in proximal geographic regions, and occurring only once every 100 to 1,000 years (Siebert and Simkin 2002-). 


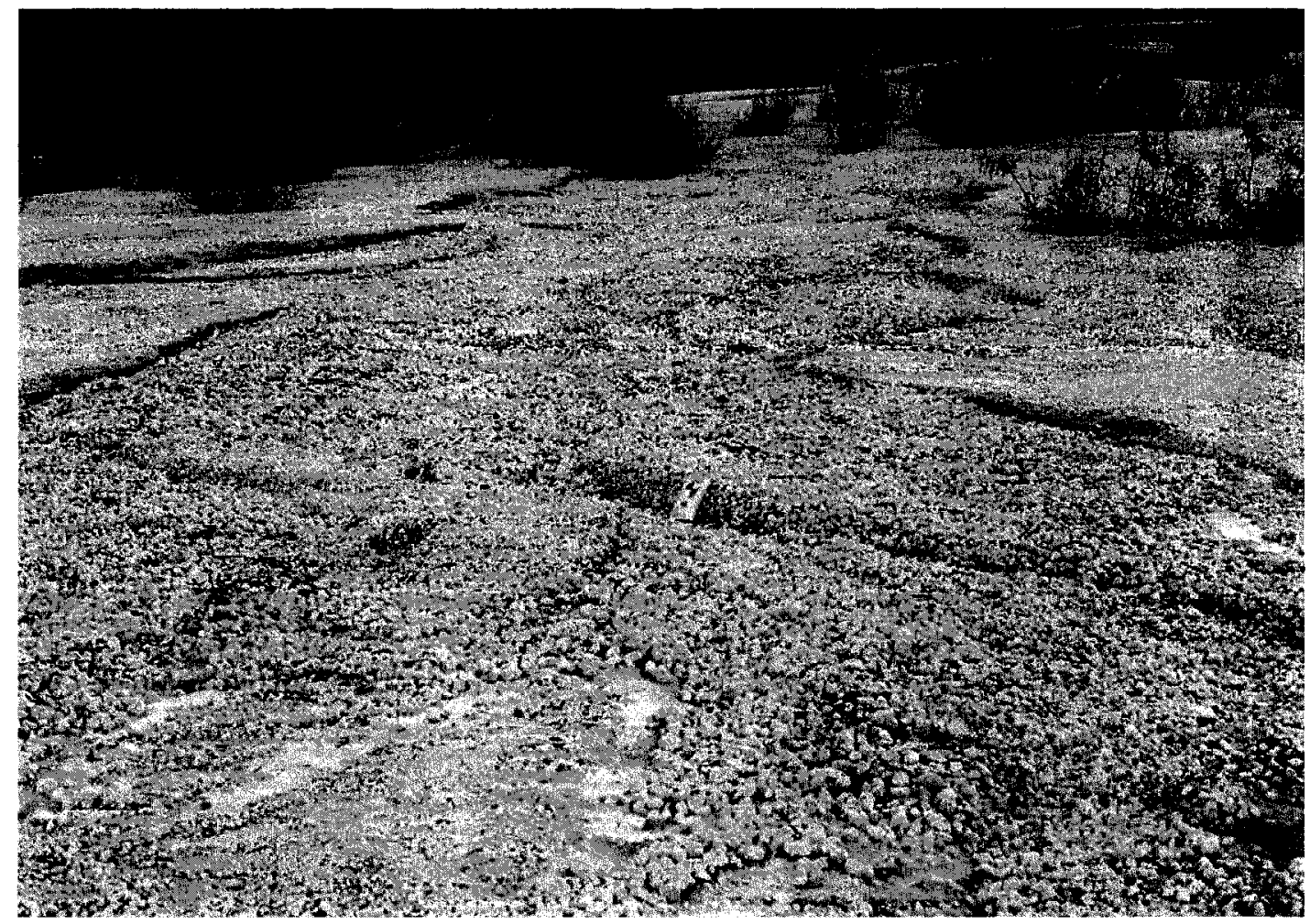

Figure 9: Resedimented clasts of rounded White River lapilli located in a fan deposit at the terminus of Klutlan Glacier (N61'36.516', W140³9.522'). 
If an explosive eruption of similar magnitude to either White River event were to occur today, areas within a $100 \mathrm{~km}(\sim 62$ mile) radius of Mount Churchill would be inundated with enough ash to collapse buildings and put regional air travel at risk. Drainages surrounding the volcano would be susceptible to the possible development of pyroclastic flows, surges, and hyperconcentrated flood flows. The impact of future eruptions on growing communities in Alaska and the Yukon, the topic of Chapter 5, would be widespread, bearing a substantial impact on the infrastructure and regional economies of Yukon and Alaska. Indeed, the impact of the east lobe White River ash still resonates in over a thousand years of oral tradition (Cruikshank 1981; Moodie et al. 1992) and is considered by some authors to have caused the permanent migration of Athapaskan peoples from the region (Workman 1974; Derry 1975; Workman 1979).

\section{Geologic Setting}

Mount Churchill, the source of White River ash, is a Holocene stratovolcano located approximately $25 \mathrm{~km}$ west of the Yukon-Alaska border $\left(61^{\circ} 25^{\prime} \mathrm{N}, 141^{\circ} 70^{\prime} \mathrm{W}\right)$ in Wrangell-St. Elias National Park and Preserve (Figure 2). Mount Churchill belongs to one of five mountain ranges in the park, the St. Elias Mountains, which extend eastward into Yukon Territory (Figure 10). Other mountain ranges in the park include the Wrangell Mountains to the northeast, the Chugach Mountains along the Gulf of Alaska, and the Mentasta and Nutzotin Mountains along the north border of the park. These ranges are not geographically distinct 


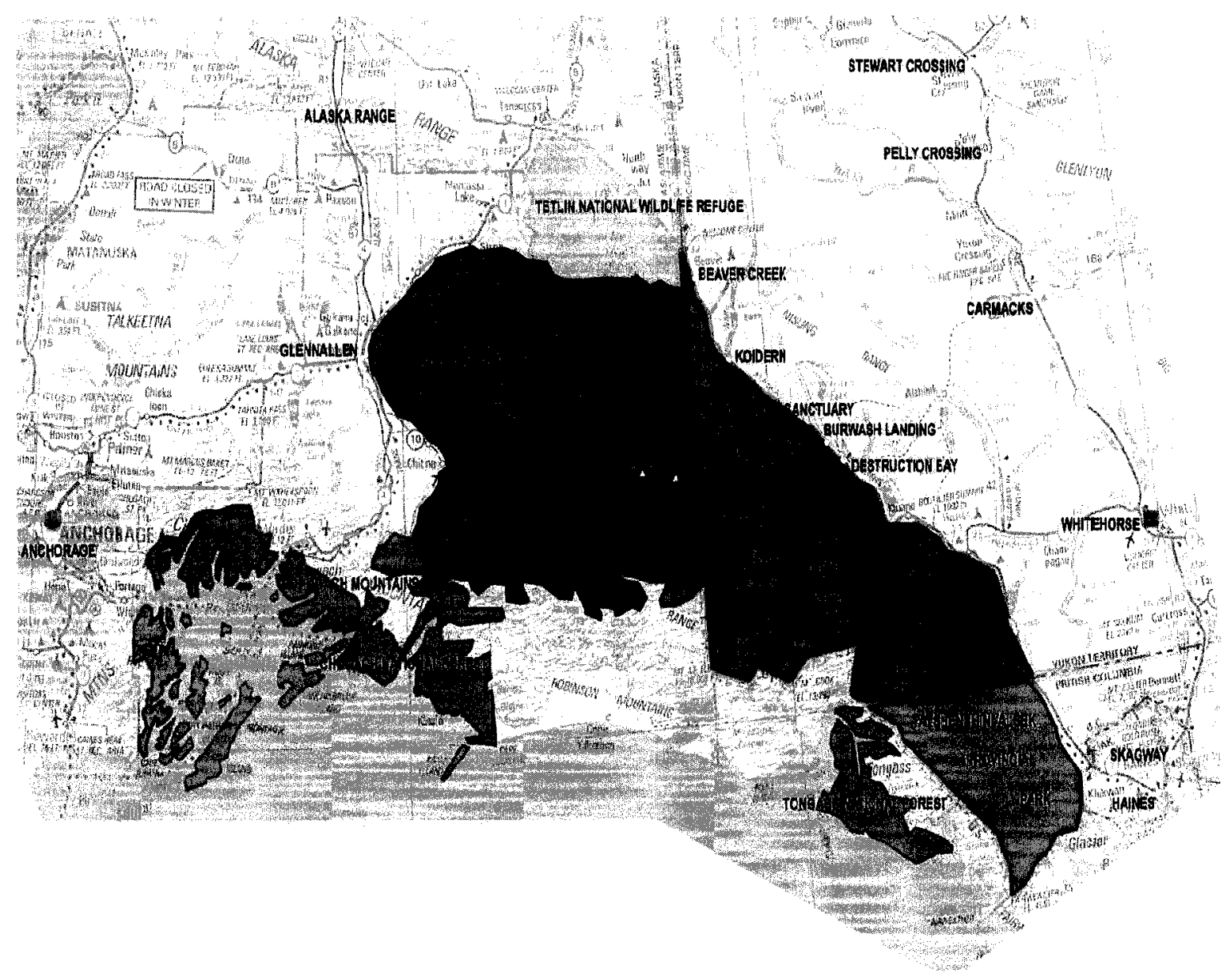

Figure 10: Kluane and Wrangell-St. Elias National Park areas. Note the four major mountain ranges in the park regions: the St. Elias Mountains, Wrangell Mountains, Chugach Mountains, and Alaska Range. Associated protected regions include Tatshenshini-Alsek Provincial Park and Tongass National Forest in British Columbia, Tetlin National Refuge (which is visited by thousands of migratory birds each spring and fall) and the Chugach National Forest in Alaska, and Kluane Game Sanctuary in Yukon Territory. The base map is published annually by the American Automobile Association (1999). 
from each other; the Mentasta and Nutzotin Mountains are part of the Alaska Range which merge with the Kluane Mountains in Canada, the Chugach Mountains are part of the St. Elias Mountains, and the Wrangell and St. Elias Mountains represent the same range (with similar rock types and formations) that is divided arbitrarily at Skolai Pass (Capps 1916).

The Wrangell and St. Elias Ranges, and parts of the eastern Alaska Range, comprise the 10,000 $\mathrm{km}^{2}$ Wrangell Volcanic Field (WVF; Miller and Richter 1994), which extends from the AlaskaYukon border into south-central Alaska. The WVF contains some of the largest and most voluminous andesitic shield volcanoes in the world (Richter et al. 1995b; Table 3). Most of the WVF is under ice; the Wrangell Mountains host the Kluane ice cap that supports numerous valley glaciers in the region (Capps 1916). Volcanic activity progressed northwestward in the field in response to subduction from 26-0.25 Ma (Richter et al. 1990). The northwestern portion of the WVF is therefore dominated by a double chain of closely spaced $(20-25 \mathrm{~km})$ shield volcanoes, partially separated by interior mesas, that are overlapping in age: Mts. Blackburn (3-4.5 Ma), Sanford (0.3-1.9 Ma), Drum (0.2-0.5 Ma), Wrangell (0-0.5 Ma), Jarvis (1.0-1.7 Ma), the Skookum Creek volcanic complex (2-3.2 Ma), and Tanada Peak (0.9- 1.6 Ma; Preece 1997; Richter et al. 1995b). A 0.9 Ma sub-linear array of cinder cones has been constructed on top of the interior mesas (Preece 1997). To the southeast, the eruptive centres are progressively older in age and include Castle (8-10 ma), Solo Creek (3-10 ma), and Sonya Creek (18-20 ma) among several others (Richter et al. 1995b). Most of the volcanoes in WVF have been dormant throughout the Holocene with the exception of Mounts Drum $(3,661 \mathrm{~m})$, Churchill (4,766 m), and Wrangell (4,317 m) (Richter et al. 1995b). 


\begin{tabular}{|c|c|c|c|c|c|c|}
\hline $\begin{array}{l}\text { Name of } \\
\text { Volcano }\end{array}$ & $\begin{array}{l}\text { Type of } \\
\text { Volcano }\end{array}$ & Location & $\begin{array}{l}\text { Altitude } \\
\text { (m) }\end{array}$ & $\begin{array}{l}\text { Snow/ } \\
\text { Ice } \\
\text { Cover } \\
(\%)\end{array}$ & $\begin{array}{l}\text { Age } \\
(\mathrm{my})\end{array}$ & $\begin{array}{l}\text { Latest } \\
\text { E ruptive } \\
\text { H istory (mya) }\end{array}$ \\
\hline $\begin{array}{l}\text { Mt. } \\
\text { Wrangell }\end{array}$ & Shield & $\begin{array}{l}62^{\circ} 00^{\prime} \mathrm{N} \\
144^{\circ} 00^{\prime} \mathrm{W}\end{array}$ & 4,317 & $98 \%$ & $0-0.75$ & Historic \\
\hline Mt. Drum & $\begin{array}{l}\text { Unknown/ } \\
\text { Modified by } \\
\text { explosive } \\
\text { / glacial } \\
\text { activity }\end{array}$ & $\begin{array}{l}62^{\circ} 07^{\prime} \mathrm{N} \\
144^{\circ} 38^{\prime} \mathrm{W}\end{array}$ & 3,661 & $98 \%$ & $0.1-0.7$ & 0.1 \\
\hline $\begin{array}{l}\text { Mt. } \\
\text { Sanford }\end{array}$ & Shield & $\begin{array}{l}62^{\circ} 13^{\prime} \mathrm{N} \\
144^{\circ} 08^{\prime} \mathrm{W}\end{array}$ & 4,949 & $90 \%$ & $0.1-0.9$ & $0.1-0.3$ \\
\hline $\begin{array}{l}\text { Capitol } \\
\text { Mountain }\end{array}$ & Shield & $\begin{array}{l}62^{\circ} 25^{\prime} \mathrm{N} \\
144^{\circ} 07^{\prime} \mathrm{W}\end{array}$ & 2,356 & $0 \%$ & 1 & 1 \\
\hline $\begin{array}{l}\text { Tanada } \\
\text { Peak }\end{array}$ & Shield & $\begin{array}{l}62^{\circ} 18^{\prime} \mathrm{N} \\
143^{\circ} 31^{\prime} \mathrm{W}\end{array}$ & 2,852 & $98 \%$ & $1.1-1.5$ & 1.1 \\
\hline Mt. Jarvis & Shield & $\begin{array}{l}62^{\circ} 01^{\prime} \mathrm{N} \\
143^{\circ} 37^{\prime} \mathrm{W}\end{array}$ & 4,091 & $98 \%$ & $1-1.7$ & 1 \\
\hline $\begin{array}{l}\text { Skookum } \\
\text { Creek } \\
\text { Volcano }\end{array}$ & Shield & $\begin{array}{l}62^{\circ} 24^{\prime} \mathrm{N} ; \\
143^{\circ} 08^{\prime} \mathrm{W}\end{array}$ & 2,172 & $0 \%$ & $2-3.2$ & 2 \\
\hline $\begin{array}{l}\text { Mt. } \\
\text { Blackburm }\end{array}$ & Shield & $\begin{array}{l}61^{\circ} 44^{\prime} \mathrm{N} ; \\
143^{\circ} 26^{\prime} \mathrm{W}\end{array}$ & 4,996 & $98 \%$ & $3.4-5$ & 3.4 \\
\hline $\begin{array}{l}\text { Boomerang } \\
\text { Volcano }\end{array}$ & Shield & $\begin{array}{l}62^{\circ} 31^{\prime} \mathrm{N} ; \\
143^{\circ} 55^{\prime} \mathrm{W}\end{array}$ & 1,204 & $0 \%$ & $>1$ & \\
\hline $\begin{array}{l}\text { Mt. } \\
\text { Gordon }\end{array}$ & Cinder Cone & $\begin{array}{l}62^{\circ} 08^{\prime} \mathrm{N} \\
143^{\circ} 05^{\prime} \mathrm{W}\end{array}$ & 2,755 & $90 \%$ & $<1$ & \\
\hline $\begin{array}{l}\text { Mt. } \\
\text { Churchill }\end{array}$ & Stratovolcano & $\begin{array}{l}61^{\circ} 25^{\prime} \mathrm{N} \\
141^{\circ} 70^{\prime} \mathrm{W}\end{array}$ & 4,766 & $98 \%$ & & $<0.001$ \\
\hline
\end{tabular}

Table 3: Volcanoes of the Wrangell Volcanic Field, their ages, location, and eruptive history. Data for the Wrangell volcanoes is compiled from Richter et al. 1995, with the exception of column 5 (Winker et al. 2000). 
Volcanic activity in the Wrangell field is related to the subduction of a composite plate (composed of Yakutat terrane and Pacific plate) underneath continental North America over the past 26 Ma (Hickson 1984; Stephens et al. 1984; Skulski 1988; Richter et al. 1990; Skulski et al. 1992; Miller and Richter 1994; Richter et al. 1995b; Winkler 2000). The WVF is bounded by numerous transform fault systems and active plate boundaries, with the Denali-Chatham Strait- Queen Charlotte Islands transform fault system to the east and northeast and the Aleutian megathrust to the west (Richter et al. 1990). The transform fault system to the east forms the Pacific and North American plate boundary and the Aleutian megathrust to the west represents a zone of active plate subduction (Richter et al. 1990). A Wrangell-Wadati Benioff zone extends to a depth of $100 \mathrm{~km}$, dipping to the northeast beneath the western, most recently active, portion of the WVF (Stephens et al. 1984; Skulski et al. 1991). The Wrangell and Aleutian Wadati Benioff zones appear to be continuous and are linked by a cuspidal buckle fold (Page et al. 1989; Preece 1997).

The Yakutat terrane originally moved northward to its present position approximately $30 \mathrm{Ma}$ ago as a result of dextral strike-slip motion along the Queen Charlotte Islands-Fairweather fault (Bruns 1983; Richter et al. 1990). From 30 to $25 \mathrm{Ma}$ ago, $225 \mathrm{~km}$ of Yakutat and Pacific terrane was subducted beneath the North American plate (Richter et al. 1990). Calcalkaline volcanism in the west end of the Wrangell volcanic field began at $26 \mathrm{Ma}$, shortly after subduction of the Yakutat and Pacific plate began, progressing in a northwesterly direction until 0.2 mya (Richter et al. 1990). Initial volcanic activity in the WVF (from 25-15 Ma) was 
sporadic, likely due to a low angle of convergence and a reduced down-dip velocity of the subducting slab (Richter et al. 1990). The earliest lavas erupted during this time may have erupted in response to regional dextral transpression (rather than subduction), as suggested by their alkaline character (Richter et al. 1990). Later eruptive products from Wrangell volcanoes exhibit medium-K calc-alkaline affinities that are more consistent with the tectonic setting (Richter et al. 1990).

Volcanism in the WVF progressed to the northwest from 26-0.2 Ma as the trench-transform junction (along the Queen Charlotte fault system) moved northwest, gradually decoupling the Yakutat terrane from North America (Richter et al. 1990). Due to a change in direction and rate of Pacific plate convergence, half of the northwesterly migration occurred in the last $5 \mathrm{Ma}$ (Richter et al. 1990). This resulted in maximum underthrusting at the northwest end of the Yakutat terrane, and as the Yakutat terrane moved northward at a faster rate with more direct convergence, magma production may also have increased, leading to the production of larger shield volcanoes instead of smaller stratocones (Richter et al. 1990). This is in agreement with several $\mathrm{K}$-Ar ages, which indicate a general progression of eruptive activity from east to west across the field (Miller and Richter 1994).

In the west end of the Wrangell volcanic field, eruptive products are $1 \mathrm{Ma}$ or younger; in the east they range from 8 to $20 \mathrm{Ma}$, with the exception of the White River ash produced by Mount Churchill (Miller and Richter 1994). Several age estimates from the southeastern region 
in Yukon Territory range from 11 to $25 \mathrm{Ma}$, which suggests that the progression of volcanism increased from approximately $0.8 \mathrm{~km} / \mathrm{Ma}$ at $25 \mathrm{Ma}$ to more than $20 \mathrm{~km} / \mathrm{Ma}$ during the past 2 Ma (Richter et al. 1990). This increased rate of volcanic progression over time is in agreement with changes in the rate and angle of Pacific plate convergence, and with the decoupling of the Yakutat terrane from North America over time (Richter et al. 1990).

By $0.2 \mathrm{Ma}$, the Yakutat terrane was decoupled from North America and Pacific plate motion was taken up by both dextral slip along the Fairweather and Totschunda faults and by compression on the Chugach fault system (Richter et al. 1990). Subduction waned, a transform regime became dominant and volcanic activity in the WVF ceased. Based on marine seismic data, there has been no subduction of Pacific oceanic crust under the Alaskan continental margin since the late Cenozoic (Bruns 1979; von Huene et al. 1979; Miller and Richter 1994). Only limited motion has occurred, reflected in weak seismicity between the Yakutat terrane and the Pacific plate (Lahr and Plafker 1980).

Vents within the Wrangell Volcanic Field are aligned with eruptive centers in the Aleutian volcanic arc, over $400 \mathrm{~km}$ to the west. The reason for this gap is not clear; it may be due to low-angle subduction of relatively buoyant lithosphere, following subduction of an intraplate island-seamount chain (Cross and Pilger 1982). However, some researchers believe that the WVF is part of the Aleutian arc (Hickson 1984) perhaps because of the seismicity and codeformation associated with the 1964 Alaska earthquake in the area south of the $400 \mathrm{~km}$ gap, 
and because of similarities in composition and age between the Aleutian and Wrangell volcanoes (Richter et al. 1990).

On a broader scale, eruptive centres within the Wrangell field belong to the much larger 500$\mathrm{km}$ long Wrangell volcanic belt (WVB) that extends southeast from Alaska into northwestern British Columbia (Skulski et al. 1991). The WVB is composed of four small volcanic fields including, from southeast to northwest, the St. Clare Creek field (18-10 Ma), Nines Creek field (15.5-13.0 Ma), Alsek field (13.5-10.8 Ma), and Stanley Creek field, in addition to the larger WVF (26 Ma to present) (Skulski et al. 1991).

The Wrangell volcanic field is constructed on Wrangellia terrane, an assemblage of allochthonous tectonostratigraphic terranes of Paleozoic and Mesozoic age including island arcs and related sediments, Mesozoic flood basalts, igneous intrusions, and limestones (Bruns 1983; Pflaker et al. 1989; Plafker and Berg 1994; Preece 1997). A small portion of the southeastern part of the field overlies the Alexander terrane (Miller and Richter 1994). The Wrangellia terrane comprises sedimentary and volcanic rocks ranging in age from Pennsylvanian to Cretaceous; the Alexander terrane is composed of similarly aged middle to late Paleozoic sedimentary rocks (Miller and Richter 1994). The St. Elias Mountains are primarily composed of Wrangell lava, Nikolai greenstone, and marine sedimentary rocks, whereas in southern portions of the Wrangell Mountains, exposures of Chitistone and Nizina limestone, Nikolai greenstone, and metamorphosed sedimentary rocks are common (Richter 
1976; MacKevett 1978; Cook and Rowlands 2002). Volcanic rocks within the WVF are almost always referred to collectively as the Wrangell Lava (Mendelhall 1905; Miller and Richter 1994), and span the range from basalt to rhyolite, with andesitic lavas dominating (Hickson 1984). The WVF also contains a variety of other related volcanic products, including rhyolite domes, lahars, tephra and volcaniclastic deposits, cinder cones, dikes, and small subvolcanic intrusions (Richter et al. 1990; Miller and Richter 1994; Richter et al. 1995a).

\section{Eruptive History}

Although the eruptive histories of many volcanic centers in the Wrangell volcanic field have been reasonably well documented (Nye 1983; Richter et al. 1990; Richter et al. 1995a; Richter et al. 1995b; Miller and Richter 1994), the eruptive history of Mount Churchill is not well known. There are few volcanic deposits near Mount Churchill, other than ash from the two White River events and a flow-banded hornblende dacite found at Churchill's summit (K-Ar date: $119 \pm 17 \mathrm{ka}$; Richter et al. 1995a). Rock outcrops are rare near Mount Churchill because of extensive glacial cover, and access to the summit is limited due to its high altitude. If it exists, it is likely that any evidence of previous effusive or explosive activity (from Mount Churchill or any of the surrounding Wrangell volcanoes) is hidden beneath the regional snow and ice cover or has been obscured by glacial action.

Historic and present-day eruptive activity in the Wrangell volcanic field is limited to sporadic phreatic eruptions of Mount Wrangell, $160 \mathrm{~km}$ northeast of Mount Churchill (Richter et al. 
1995b). In the WVF, explosive catadysmic-style eruptions similar to the White River events are rare. Most eruptive centres are andesitic shield volcanoes, with calderas that formed passively in response to subvolcanic removal of magma (Preece 1997). The one exception is Mount Drum (or possibly, Mount Wrangell) that produced plinian-style eruptions and lahar deposits in the Chitina region approximately 100,000 years ago (Richter et al. 1995b; Waythomas and Wallace 2002). Mounts Drum and Churchill occur at opposite ends of the WVF. Their chemical signatures (adakites) are distinct from the rest of the Wrangell volcanic field and appear to be related to partial melting of young underplated basalt or of the downgoing slab (Preece 1997).

\section{Paleoenvironment and Glacial History}

\section{Pleistocene}

Quaternary glaciations of the St. Elias Mountains (where Mount Churchill is located) have been studied in detail in many areas in southwest Yukon, including the Shakwak trench, near Kluane Lake (Denton and Stuiver 1966; 1967), the Snag-Klutlan area near the Alaska-Yukon border (Rampton 1969, 1971a), the White River in Alaska (Denton 1974), and to a lesser extent, the Kaskawalsh and Donjek glaciers (Borns and Goldthwait 1969), as well as the Steele glacier (Sharp 1951). A general mid-continental glacial sequence for the St. Elias Mountains defines the Icefield, Mirror Creek, and the Macauley-Kluane glaciations during the Wisconsin (Denton 1974). During the Macauley-Kluane glaciation, the Klutlan and Natazhat Glaciers were part of the Macauley-Kluane piedmont glacier that reached $80 \mathrm{~km}$ down the White River 
from the mouth of the Generc River. At this time, the ice at Klutlan Glacier's terminus was approximately $150 \mathrm{~m}$ thicker than at present. The Macauley-Kluane glacier reached its maximum extent approximately 14,000 years B.P. and rapidly disintegrated in 2,700 to 1,500 years as a result of worldwide climate change.

\section{Early Hypsithermal (10,000- 4,000 years B.P.)}

Climate conditions were warming nearly 10,000 years ago, resulting in the retreat of many mountain glaciers in the northwest Cordillera and the subsequent deposition of the Kluane loess and Slims soil in the southern periphery of the St. Elias Mountains (Borns and Goldthwait 1969; Denton and Stuiver 1969; Johnson and Raup 1964). During this time, widespread aeolian working of loess and silt occurred in the Kluane basin and Shakwak/ Dezadeash valleys (Denton and Stuiver 1969; Workman 1974). An ice dam on the Alsek river was also removed during this time, allowing drainage of a large impounded lake and the opening of much more dry land (Johnson and Raup 1964; Workman 1974).

Records of vegetation during the Hypsithermal are deduced from studies in the Snag-Klutlan area in Yukon Territory (Rampton 1971b), the White River valley in Alaska (Denton and Karlén 1977), and the Kluane-Dezadeash-Shakwak areas in Yukon Territory (Johnson and Raup 1964). Rampton (1971b) suggests that spruce forests in the Snag-Klutlan area have been around since 5700 B.P., while Denton and Karlén (1977) suggest that spruce may have been present in the White River valley longer (i.e. 8020 B.P.). Johnson and Raup (1964) suggested that the Kluane-Dezadeash-Shakwak areas were predominantly open grassland throughout the 
Hypsithermal; the spruce forests characteristic of the Snag-Klutlan and White River valley regions did not invade this area (except along stream courses and lake shores) until after deposition of the ash (Johnson and Raup 1964; Workman 1974). Bison were present in the area around Fort Selkirk and southwest Yukon, as evidenced by archaeological investigations by Workman (unpublished) and MacNeish (1964).

\section{Neoglaciation (4,000 years B.P. to present)}

A major glacial advance has been noted in western North America and around the world from c. 2600-2800 B.P. (Workman 1974). Neoglacial advances in non-glaciated regions in southwestern Yukon were accompanied by deposition of Slims River loess beginning approximately 2640 B.P., after a long Hypsithermal interval of non-deposition and soil development (Denton and Stuiver 1969; Workman 1974). The end of the Hypsithermal is fixed along the southern Alaskan coast between c. 4000 years ago (Gulf of Alaska) and 3500 years ago (southeast Alaska; Porter and Denton 1967; Workman 1974). Neoglaciation began in the St. Elias Mountains c.3310 \pm 100 BP (Workman 1974).

In southwestern Yukon, the Slims River loess was deposited over at least 10,000 square miles (Borns and Goldthwaite 1969). In soil profiles across the region, the loess lies beneath the White River ash, indicating that deposition occurred prior to the eruptive events (Johnson and Raup 1964). Widespread evidence also exists for high stands of Kluane Lake prior to the deposition of east lobe ash (Bostock 1969; Johnson and Raup 1964, Neish 1964, Workman 1974). During the Neoglacial, several lakes in eastern Yukon were ice-dammed 
due to the reblockage of the Alsek River (Workman 1974). Elevated water levels due to this blockage may have produced inhospitable land in most of the Shakwak and Dezadeash valleys and a decrease in food supply in this area (produced by the blockage of salmon runs from the Pacific; Workman 1974). It is entirely possible that these areas, which house the majority of residents currently living in the Yukon, may not have been occupied by indigneous peoples around 1147 years B.P. (Workman 1974).

Many glaciers in the North American Cordillera seem to have begun their Neoglacial activity prior to 2800 B.P., reaching their peak during the last 250 years (Porter and Denton 1967; Viereck 1968). The earliest recorded advance of the Natazhat glacier dates from this interval and the earliest advances from the Klutlan Glacier, between 1520 B.P. and 800 B.P., coincide with advances by glaciers those along the southeastern coast of Alaska (Porter and Denton 1967). Klutlan Glacier did not reach its Neoglacial maximum until after the deposition of the east lobe White River ash (Rampton 1971a). Glaciers in the Alaska Range began their Neoglacial activity before 250 B.P. (Péwé 1965; Reger 1968). Since 1947, Klutlan and Natazhat Glaciers have been losing volume near their termini as have all other nearby glaciers (Rampton 1970).

\section{Previous Studies}

Given the scale and magnitude of the White River eruptions, it is not surprising that anecdotal evidence of what we suspect to be the east lobe eruption appears in the oral traditions of local 
Athapaskan peoples. Early explorers and surveyors in the late nineteenth century were the first to write reports on the ash. The first of these reports was written by F. Schwatka, who observed a "conspicuous" ash layer during an expedition along the Yukon River from Teslin Lake to Fort Selkirk (Schwatka 1885). Schwatka's expedition was followed shortly after in 1887 by another led by G.M. Dawson of the Geological Survey of Canada. In his report, Dawson was the first to map the distribution of the ash and to provide a volume estimate of the deposit $\left(1.87 \mathrm{~km}^{3}\right.$ or $1.16 \mathrm{mi}^{3}$; Dawson 1888). He also noted that the thickness of the White River tephra increased towards Alaska, and suggested that the source of the deposit was a volcano in the Wrangell Group.

In 1891, a third expedition to the Upper Yukon Basin from Fort Selkirk to the White River was made, this time by C.W. Hayes. During this expedition, Hayes recorded the thickness and distribution of the ash, and he recalculated the volume of the deposit to be $266 \mathrm{~km}^{3}$ (165 $\mathrm{mi}^{3}$; Hayes 1892). This calculation was exaggerated from Dawson's initial estimate because Hayes incorrectly assumed that the geometry of the deposit was conical. Hayes suggested Mount Natazhat, located approximately $11 \mathrm{~km}$ (7 miles) west of the Alaska/ Yukon border within the Wrangell group, to be the source of the White River ash.

In 1910, the first petrographic description of the White River ash was included in a report on the Nabesna and White River basins (Moffit and Knopf 1910). Several observations of the deposit were also made in the vicinity of the headwater regions of the White and Tanana 
Rivers (Brooks 1900). The first isopach map of the deposit was created by S.R. Capps (1915), who estimated the volume of the deposit to be approximately $41 \mathrm{~km}^{3}$ (10 cubic mi $\left.{ }^{3}\right)$. During construction of his isopach map, Capps made two incorrect assumptions, namely that the tephra distribution of the deposit was represented by one lobe of ash and that the source of the deposit was Mount Natazhat. He was, however, the first to refer to the deposit as the "White River ash" (Hanson 1965).

The true bilobate geometry of the White River deposit was not recognized until several decades later, in 1952. H.S. Bostock was the first to construct an isopach map based on this distinction. He also revised the total volume of the deposit to $20 \mathrm{~km}^{3}$ or $12.5 \mathrm{mi}^{3}$ based on thicknesses recorded by Hayes, and he was the first to devise a more accurate rock-equivalent volume for the deposit $\left(3.41 \mathrm{~km}^{3}\right.$ or $\left.2.12 \mathrm{mi}^{3}\right)$. In 1960, A.R. Berger recalculated the rockequivalent volume of the deposit to be 2.3 to $3.5 \mathrm{~km}^{3}$ or 1.4 and $2.15 \mathrm{mi}^{3}$, based on a much smaller estimate of maximum thickness $(3 \mathrm{~m}$ or $10 \mathrm{ft}$ ) and differences in porosity and interspace porosity corrections.

After Bostock and Berger's volume calculations, researchers focused their attention on determining the age of the deposit. Radiometric ages of the White River ash have mostly been acquired through ${ }^{14} \mathrm{C}$ dating of the peat layer directly overlying the ash. Capps (1915) originally estimated the age of the deposit to be 500 A.D. (1400 years B.P.) based on the rate of overlying peat accumulation in the area (Hanson 1965; Richter et al. 1995a). These 
observations were based on a bog exposed in the bank of the White River $40 \mathrm{~km}(25 \mathrm{mi})$ northwest of Mount Natazhat (Stuiver et al. 1964).

Later workers followed Capps' assumption and reported a range of radiocarbon ages for a single deposit of White River ash. Johnson (1944) reported an age of 430 A.D. $(1519 \pm 150$ years) that was based on charcoal samples derived from the tephra. Subsequent radiocarbon estimates derived in the 1960 s by a collaboration of authors (Fernald 1962; Stuiver et al. 1964; Lowdon and Blake 1968) yielded a wide range of ages from 1300 to 2000 years B.P. Fernald (1962) averaged two dates of ash from peat immediately above and below the layer of ash $(1520 \pm 100$ years B.P. and $1750 \pm 150$ years) in the Tanana River Valley to arrive at an estimate of $1635 \pm 80$ years. Stuiver, Borns, and Denton (1964) followed similar methodology, dating samples of peat from above the ash layer $(1460 \pm 70$ years B.P.) and below the ash layer ( $1390 \pm 70$ years B.P.). This study resulted in a suggested age of $1425 \pm 50$ years B.P.

Subsequent work on the White River ash led to identification of the true bilobate nature of the deposit, thus broadening the field of radiocarbon age estimates to two individual age estimates, one for each lobe. Lerbekmo et. al (1975) were the first to suggest two estimates for the individual lobes of the deposit, 1887 years B.P. for the north lobe, and 1250 years B.P. for the east lobe. Since then, further work with improved ${ }^{14} \mathrm{C}$ calibration has yielded a more precise assessment of 1140 B.P. for the east lobe ash (Clague et al. 1995). This estimate was based on 
a sample taken from a stump in growth position that was buried in White River lapilli at Little Boundary Creek, approximately $30 \mathrm{~km}(18 \mathrm{mi})$ from the vent. Although this estimate is consistent with several limiting ${ }^{14} \mathrm{C}$ ages from sediments above and below the tephra at sites distant from the volcano (Clague et al. 1995). Recent work by Jensen and Froese (2006) also suggests that the north lobe was deposited between 150-500 AD (based on dating of floodplain exposures along the Yukon River) and the east lobe at approximately $800 \mathrm{AD}$.

For more than half a century since the discovery of the White River ash, perennial snow and ice in Alaska and the Yukon have posed problems in the determination of its source. Consequently, many sources for the deposit have been considered, including Mount Natazhat (Hayes 1892; Capps 1915; Bostock 1952; Berger 1960), Mount Bona (Hanson 1965), and a pumice mound located on the upper reaches of the Klutlan Glacier (Lerbekmo and Campbell 1969; Downes 1979; Downes 1985). Mount Natazhat, $11 \mathrm{~km}$ (7 mi) west of the Alaska-Yukon border, was initially considered as the source of the White River ash because of the increase in thickness of ash towards Alaska (Hayes 1892; Capps 1915; Bostock 1952; Berger 1960). In 1965, Hanson derived the position of the White River vent from size distribution parameters of expelled tephra, and he suggested the source to be Mount Bona, $40 \mathrm{~km}$ southeast of Mount Natazhat. In 1969, a prominent pumice mound identified from aerial photographs was suggested to be the source of the deposit (Lerbekmo and Campbell 1969). This mound, in the upper region of the Klutlan Glacier, was discredited as the source when White River ash was discovered at the summit of Mount Churchill complex in 1990 (McGimsey et al. 1990). 
The summit expedition to Mount Churchill in 1990 by the United States Geological Survey revealed new information not only about the source of the White River ash, but also about the nature and areal extent of the vent and proximal deposits of ash. Proximal deposits consisted primarily of resedimented ash, lapilli, and blocks up to $50 \mathrm{~cm}$ in diameter, and were concentrated in embayments, valleys and elevated terraces, in which they were up to $50 \mathrm{~m}$ thick (McGimsey et al. 1990; Richter et al. 1995a). An elongate and ice-filled vent, approximately $2 \mathrm{~km}$ in diameter, was discovered with an opening towards the northeast (Richter et al. 1995a). Rarer lithic fragments of porphyritic andesitic lava, granite, chlorite-rich amygdaloidal lava, hydrothermally altered pumice and lithics, bedded tephra, and a flowbanded hornblende dacite dated at $119 \pm 17 \mathrm{ka}(\mathrm{K} / \mathrm{Ar})$ were also discovered in the summit region (Richter et al. 1995a).

The first petrologic and geochemical analyses of the White River deposit were obtained in the late 1960s. At this time, it was discovered that the ash is a dacitic to rhyodacitic deposit (Lerbekmo and Campbell 1969; Lerbekmo et al. 1975; Richter et al. 1995a), composed primarily of glass, plagioclase, hornblende, hypersthene, and magnetite in decreasing order of abundance (Lerbekmo and Campbell 1969; Table 2). The average chemical composition of the deposit is silicic, but $\mathrm{Al}, \mathrm{Ti}, \mathrm{Mg}, \mathrm{Fe}, \mathrm{Na}, \mathrm{K}$, and $\mathrm{Ca}$ also occur in significant proportions (Lerbekmo and Campbell 1969). The glass component of sampled ash increased significantly with respect to crystal components downwind, and was dominantly pumiceous with a 
refractive index of $\mathrm{n}=1.502$ (Lerbekmo et al. 1975). These initial analyses were made by electron microprobe in order to distinguish between the two lobes by their glass composition, to determine whether the glass composition varied with stratigraphic height in the deposits, to confirm whether the White River deposit was homogeneous, and to ascertain the petrologic characteristics of the deposit. Later geochemical investigations focused on determining the nature of zonation of the magma chamber, and on the conditions of pressure, temperature, water saturation, and melt composition which existed in the source during the eruptions (Downes 1979; Downes 1985).

Techniques such as microprobe, neutron activation, and $\mathrm{x}$-ray fluorescence (XRF) were traditionally used in the initial identification of the White River ash. These techniques measured the elemental concentrations in glass or selected mineral grains, using basic variations in major and trace-element compositions to differentiate between deposits. In 1969, Lerbekmo and Campbell's electron microprobe study of glass compositions revealed that the east and north lobe ash were both rhyodacites, identical in gross composition and mineralogy. The lobes were therefore impossible to tell apart using traditional methods of chemical identification. More recent work by Donaldson et al. (1996) revealed subtle differences in the $\mathrm{SiO}_{2}$ contents of the north and east lobes of ash (Table 2). In addition, Lerbekmo and Campbell (1975) revealed that the lobes could be distinguished from each other by compositional differences in the ilmenites of each deposit. Differences between the Ti and Fe contents are evident; less distinctive differences in $\mathrm{Mg}$ and $\mathrm{Mn}$ values were observed 
(Lerbekmo and Campbell 1975). The north lobe ash consistently displays higher $\mathrm{TiO}_{2} / \mathrm{MgO}$ and lower $\mathrm{FeO}$ hematite/ilmenite series minerals, whereas the east lobe ash displays the opposite (Lerbekmo et al. 1975). Additional studies of the variation in chemical composition of the volcanic glass and the iron-titanium oxides also revealed that the magma that produced the White River ash was chemically zoned prior to each volcanic eruption.

In 1964, Buddington and Lindsley provided the experimental basis for using the compositions of coexisting titaniferous magnetites and ferrian ilmenites as a geothermometer-barometer. This work has been used to more precisely determine the magma chamber conditions during eruption of the north and east lobes of ash. Additional studies by Lerbekmo et al. (1975) and Downes (1985) considered the $\mathrm{T}-\mathrm{fO}_{2}$ conditions of crystallization of co-existing magnetite and ilmenite. Lerbekmo et al. (1975) initially estimated a range of temperatures from 830 to $1005^{\circ} \mathrm{C}$ for the north lobe eruption and 1035 to $1125^{\circ} \mathrm{C}$ for the east lobe eruption. Downes (1985) later revised these estimates to a range of $950-990^{\circ} \mathrm{C}$ for eruption of the north lobe and $995-1030^{\circ} \mathrm{C}$ for the east lobe. Differences between $\log \mathrm{fO}_{2}$ values also were reported between the studies, ranging from 11.5 to 8 (north lobe) and 7.5 to 6.5 (east lobe) (Lerbekmo et al. 1975) from 9.3 to 8.3 (north lobe) and from 8.3 to 7.7 (east lobe) (Downes 1985). The results of both studies demonstrate differences in crystallization conditions that were suggested to be indicative of a more violent eruption for the east lobe than for the north lobe (Lerbekmo et al. 1975). To account for the variations in explosivity levels between the north and east lobe ash, it was suggested that the east lobe ash may have been produced by tapping of a deeper and 
consequently higher temperature level in the magma chamber (Lerbekmo et al. 1975), or alternatively, that the magma chamber was compositionally inhomogeneous prior to both eruptions (Downes 1985). Additional isotopic differences between the proximal and distal deposits of the east and north lobe ash may further support the notion of a stratified magma chamber.

Subsequent geochemical studies of the White River ash focused on comparisons of megascopically similar pumice from the slopes of Mount Churchill and pumice previously linked with the White River tephra in order to provide evidence for the source of the deposit (McGimsey et al. 1990). Samples of pumice from Mount Churchill and from more distant deposits of White River ash yielded variations in sample sets, but the average chemical compositions of the sources were observed to be similar (McGimsey et al. 1990). An important distinction noted by these researchers was the presence of biotite in the Churchill pumice and the relative absence of this phase in the White River pumice (McGimsey et al. 1990). The average chemical similarity of the Churchill and White River pumice provides evidence that both deposits likely originated from the same source, and that compositional differences may simply reflect chemical inhomogeneities (Downes 1985), or an insufficient database (McGimsey et al. 1990). Recent work by Richter, Preece, McGimsey, and Westgate (1995) indicates that samples analyzed from the summit of Mount Churchill yield Fe-Ti oxide compositions indicative of the east lobe ash. 
On a more regional scale, the volcanic complexes and major tephra layers of the Wrangell and St. Elias region of Alaska and the Yukon have been divided into several geochemical subdivisions based on their geographical distribution. According to this classification, the White River ash is part of the Trend $2 \mathrm{~b}$ magmatic system, from which all Type II tephra beds in Alaska and Yukon are inferred to have originated (Preece 1997). Recent research suggests that the magmatic system which produced the White River ash contains an adakite end member, commonly derived from melting of young underplated basalt in a continental arc setting (Preece 1997).

Sedimentological research on the White River ash has been largely investigated within, but not restricted to, proximal deposits of ash. One study by Robinson (2001) focused on the distribution of distal deposits by examining ash in peatlands, which preserve the tephra exceptionally well. His study concluded that distribution $\left(540,000 \mathrm{~km}^{2}\right)$ and volume $\left(27 \mathrm{~km}^{3}\right)$ of the deposit was much more extensive than previously thought. Other studies are limited to a facies analysis of a pumice terrace located $40 \mathrm{~km}$ east of Mount Churchill on the north side of Klutlan Glacier (Donaldson, Mueller, and Guerstein 1996). Proximal facies largely occur in the form of pumice terraces (Figure 7) and fans (Figure 9) close to the source vent, at the base of the Klutlan Glacier. Geochemical analyses of these proximal tephra deposits have revealed compositional similarities to samples of distal east lobe ash (Richter et al. 1995a). 
A detailed facies analysis of the pumice terrace indicates that beds composing the terrace were deposited under subaqueous depositional conditions (Donaldson et al. 1996). Provenance of tephra composing the terraces was attributed to a proximal source vent, and the terraces were suggested to have formed as the result of a hyper-concentrated glacial flow, over and along the margins of Klutlan Glacier (Donaldson et al. 1996).

Several anthropologists have suggested that the east lobe eruption was of sufficiently devastating stature to cause the migration of Athapaskan peoples from the Yukon-Alaska area to the southern United States (Workman 1974; Derry 1975; Workman 1979; Cruikshank 1981; Moodie et al. 1992; Harris 2000). Locally the White River eruptions may have produced flooding (associated with the melting of glaciers near the summit of the volcano), hyperconcentrated flood flows, and possibly, pyroclastic flows. The tephra fall over the area would have killed vegetation and most of the fauna in distal and surrounding areas, leaving little for human subsistence. Interestingly, the tale of a terrible volcanic eruption, similar in age and magnitude to the east lobe eruption of White River ash has been passed down from generation to generation via First Nation oral tradition (Harry Heinz, personal communication, 1998). 


\section{Chapter 2: Evidence for a Late Fall or Early Winter Emplacement of East Lobe White River Ash}

\section{Introduction}

In much of the southern Yukon Territory, the White River ash bears striking resemblance to fresh snow. The deposit is composed of unconsolidated ash and pumice and occurs as a thin layer atop gravel pits and along the sides of roadways and riverbanks (Figure 11). The ashfall rendered much of the southern Yukon Territory and portions of western Alaska uninhabitable during two cataclysmic eruptions ca. 1147 (Clague et al. 1995) and 1887 years B.P. (Lerbekmo et al. 1975; Figure 1). Recent work by Jensen and Froese (2006) suggests the northern lobe of ash covered approximately $100,000 \mathrm{~km}^{2}$ and the eastern lobe covered approximately 500,000 $\mathrm{km}^{2}$. The source of the ash is Mount Churchill (McGimsey et al. 1990; Figure 2), one of the few volcanoes in eastern Alaska that has been active during the Holocene. The sheer magnitude of the White River eruptive events is extraordinary; both are among the top ten percent of the world's most violent Holocene eruptions (Siebert and Simkin 2002-) and are classified as 'paroxysmal' volcanic events (VEI: 6; Table 1). The youngest eruption of White River ash is associated with high sulphate peaks around 703 A.D. in the Greenland (GISP2) ice core (Zielinski 1995). 


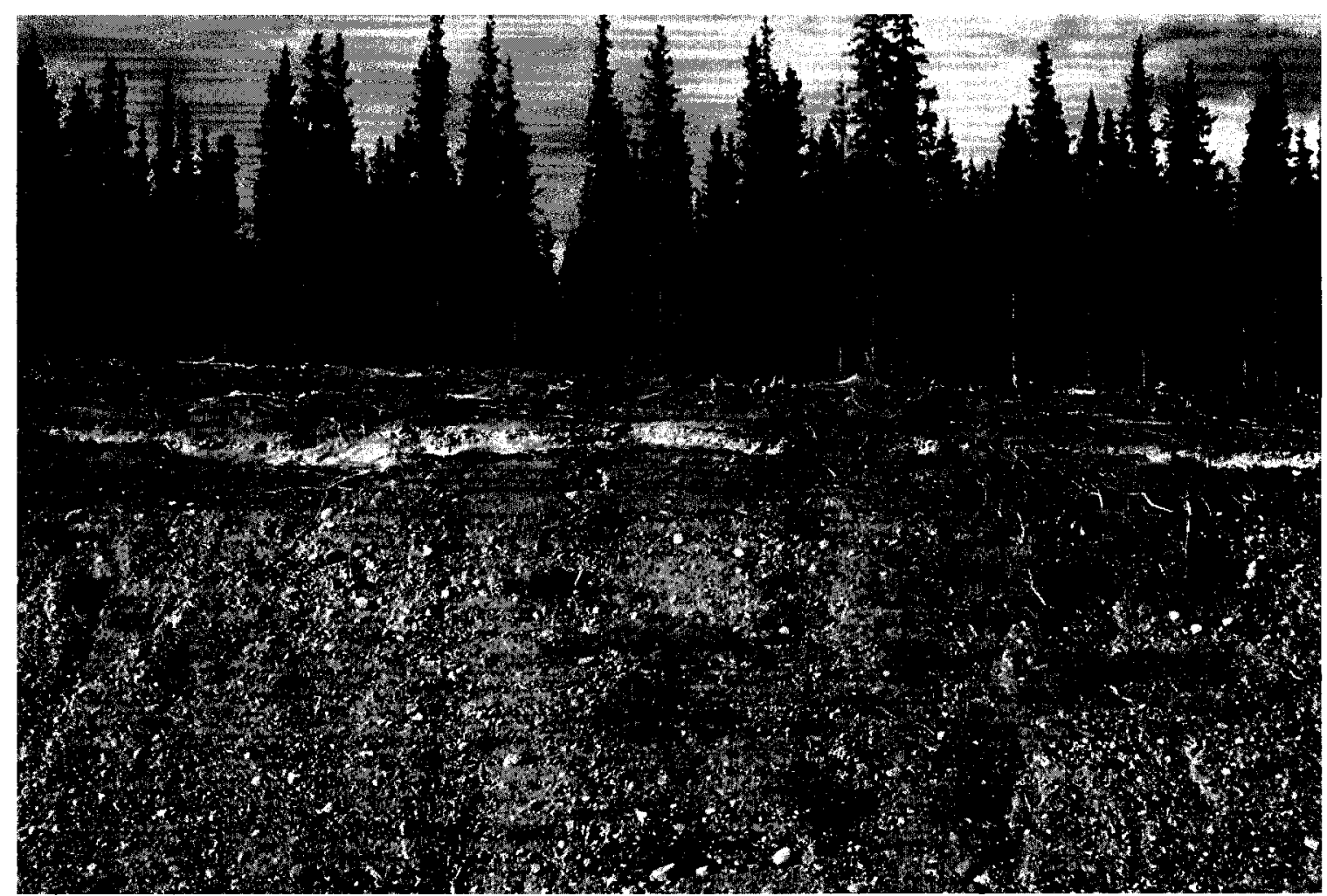

Figure 11: Distal deposits of ash, like this one along the Alaska Highway, range in size and thickness depending on distance from Mount Churchill. This is a layer of east lobe ash near Haines Junction (Yukon Territory). 
Given the scale and magnitude of the White River eruptions, it is reasonable to conclude that the ash falls would have significantly affected the way of life of ancient peoples (Workman 1974; 1979; Cruikshank 1981; Moodie et al. 1992; Harris 2000). Anecdotal evidence of what we suspect to be the east lobe eruption of ash is present in the oral traditions of Athapaskan peoples, who lived in the area during the time of the White River eruptions (Cruikshank 1981; Moodie et al. 1992; Harry Heinz, personal communication). Oral narrative represents an intelluctual tradition that is collective (representing the social thinking of a group) rather than individual, as are most scientific contributions (Cruikshank 1981). In some regions, oral traditions provide the only knowledge we have of prehistoric cultural or natural events (Spooner et al. 1996). This collection of 'social thinking' allows us an unique opportunity to gain insight about geological processes, and to assess more diversely (through human experience) the impact of past large-magnitude eruptions on the environment, climate, and perhaps most importantly, on humans, archaeology, and history. Many authors, including Laguna (1958; 1964; 1972) and more recently, Souther (1970), Blong (1982) and Moodie et al. (1992) have used oral traditions in confirming volcanic events and their timing (Spooner et al. 1996). For example, oral traditions in the Mount Edziza region of British Columbia have indicated that volcanic activity of Edziza may have occurred within the last millenium, a startling revelation that should result in re-evaluation of the eruptive history of Mount Edziza (Spooner et al. 1996).

Workman (1979) has suggested that large magnitude volcanic eruptions (like the White River 
events) which profoundly affect and change human civilizations should be classified as 'culturally significant' events. The younger eruption of White River ash (ca. 1147 years B.P.) may fall into this category, as many authors believe that the eruption triggered a massive migration of the Athapaskan peoples eastward into the Mackenzie valley (Workman 1974; Derry 1975; Workman 1979; Cruikshank 1981; Moodie et al. 1992; Harris 2000). Evidence for a change in population (i.e. migration) has been gathered from: 1) linguistic data indicating differentiation of the Athapaskan language during this period; 2) oral tradition (which blames a volcanic eruption for the differentiation of Athapaskan language); or 3) a change in tool construction at around the same time as the east lobe eruption (Cruikshank 1981; Moodie et al. 1992; Harris 2000; Hare et al. 2004). Furthermore, a migration may have been spurred on by the harsher conditions brought on by an eruption of ash during the winter (Workman 1974; 1979; Hanson 1965).

This chapter does not seek to substantiate all of the above claims, most of which require more archaeological evidence. However, it does attempt to substantiate the last claim by determining the season in which the east lobe ash was deposited and by elucidating and clarifying the cultural and environmental ramifications of this timing. If the east lobe ash triggered a massive migration, it must have had a significant impact on the land and its people. Furthermore, the impact of such a large-magnitude eruption on vegetation, fauna, and the Athapaskan peoples subsisting on the land would have had more severe consequences in winter than at different times of the year (Workman 1979; Moodie et al. 
1992).

This chapter presents a new approach, based on sedimentological observations of distal east lobe ash, that determine the season of deposition. Although pumice is a widespread product of many pyroclastic eruptions, its behaviour during post-eruptive processes has rarely been studied in detail. Recent evidence from a frozen layer of airfall ash near Bock's Brook, Yukon Territory indicates that the east lobe eruption of White River ash occurred during the late fall or early winter (West and Donaldson 2000, 2002). Similar evidence for emplacement is provided by ice-cemented pumice clasts discovered near Donjek River, Yukon Territory (West and Donaldson 2000, 2002). The approach is presented in three stages: first, the context of the evidence is presented by a description of typical features of the distal ash deposits; secondly, the evidence for winter emplacement is presented, and lastly, the implications of this new find (including the impact on Athapaskans) are discussed to conclude the chapter.

\section{The White River Ash}

The striking color of the White River ash, together with its widespread presence within the top few centimeters of the soil, has engendered lots of curiosity among residents and tourists. Few people know about the volcanic origin of the deposit, much less the cultural and environmental ramifications that would have been associated with the eruptions, even though it is often used as a chronostratigraphic marker within the region (Figure 12). 


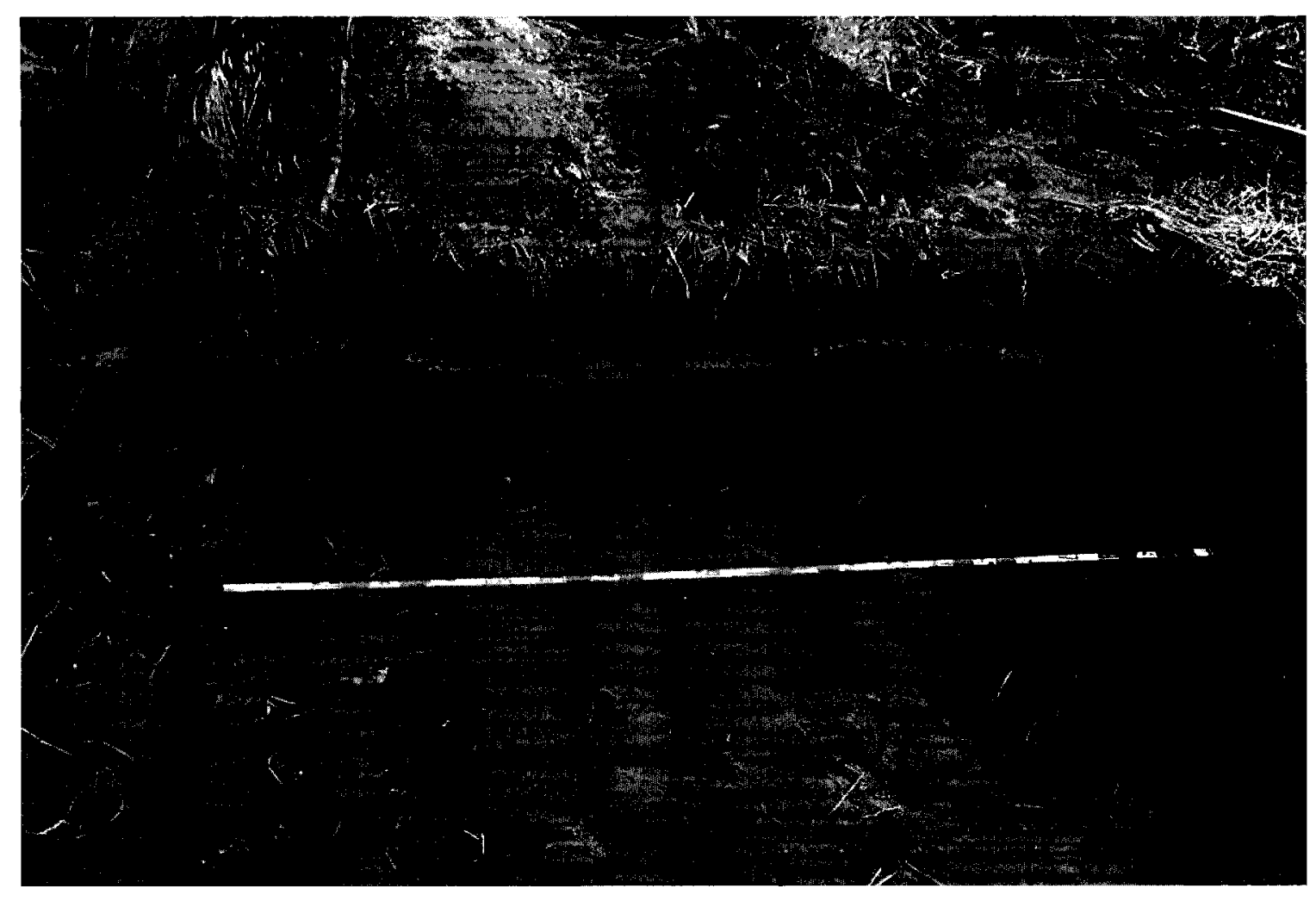

Figure 12: The striking white color of the White River ash aids in its recognition in soil profiles across the Yukon Territory. In this archaeological site near Beaver Creek, the east lobe ash is being used as a chronostratigraphic marker. 
Distal deposits of White River ash range in size from clay to granule-sized particles depending on distance from Mount Churchill. Most of the deposit is moderately sorted and composed of angular to subround fragments of ash or pumice lapilli. In the zone of overlap, the east lobe ash $(0.125-0.25 \mathrm{~mm})$ lies stratigraphically above the north lobe ash $(0.25-0.5 \mathrm{~mm}$; Figure 4$)$. On average, the east lobe ash is coarser-grained and more widely distributed than its north lobe equivalent, owing to the more intense magnitude of the younger eruptive event (Downes 1979).

The striking color of both lobes of White River ash is due to its silica-rich composition; a slight beige staining is often attributed to leaching of organics from surrounding soil horizons (Crampton 1982). Most deposits occur within centimeters of the soil surface as laminae in beds of glacial silt and sand. With increased distance from Mount Churchill, the ash becomes patchy and finer-grained, appearing as discontinuous lenses. Closer to the source, the ash occurs as tabular cm-thick beds that are laterally traceable for distances up to several kilometers. Thicknesses of the deposit range from 3 to $60 \mathrm{~cm}$ (1 to 25 inches) throughout most of the sampled region east of the Alaska Highway. Maximum thicknesses of the deposit have been observed approximately 88 kilometers west of Mount Churchill, where ashfall from the east lobe eruption is up to $0.6 \mathrm{~m}$ or $2 \mathrm{ft}$ thick along the highway outside of Koidern, Yukon Territory (Figure 13). 


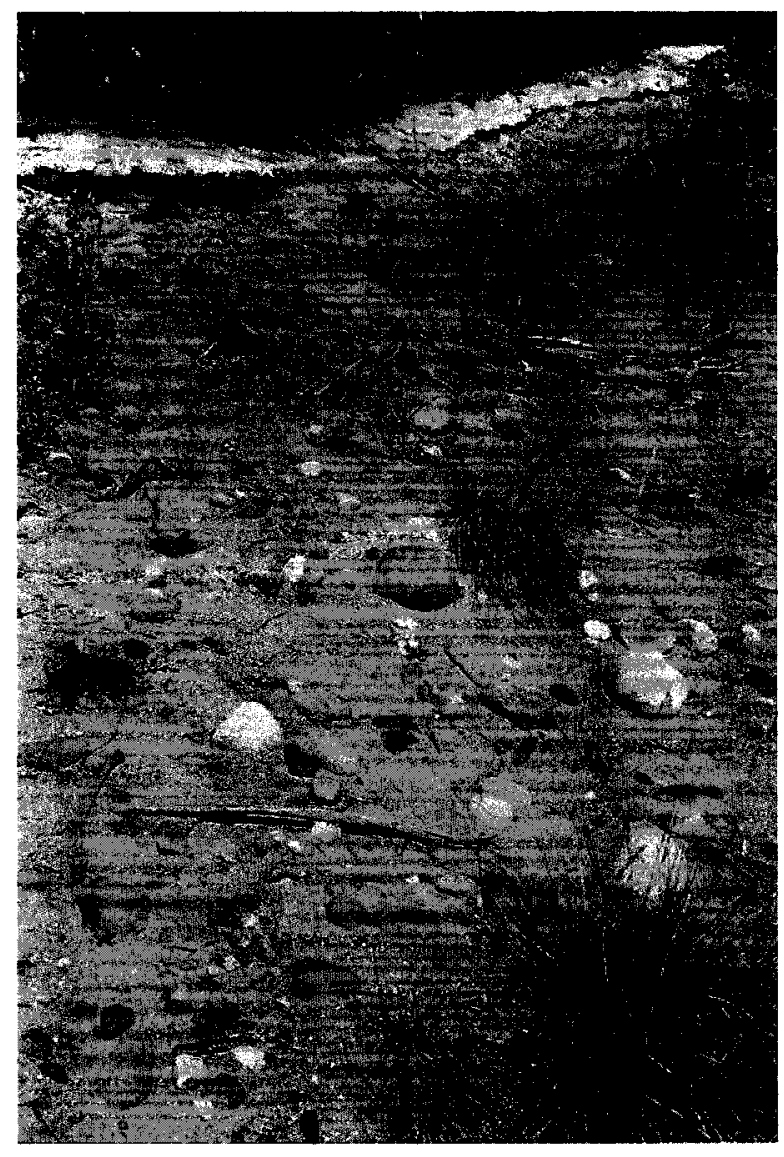

Figure 13: Maximum thickness of east lobe ash along the Alaska Highway near Koidern, Yukon Territory. Penknife, near bottom of photo, is approximately $8 \mathrm{~cm}$ in length. 
Characteristics of the White River ash are consistent with features of primary ashfall deposits, considered by Tucker (1991) to include good or moderate sorting of angular fragments in slightly graded or laminated beds, compositional homogeneity within layers, and a gradual decrease in bed thickness and particle size as distance increases from the site of eruption. In most cases, the ash layers display a sharp and prominent lower contact with the substrate; the upper contact tends to be more irregular and gradational (Figure 14). Irregularities along the upper contact may be due to cryoturbation or downslope solifluction, which produces truncations and nebulous transitions to silt or organics in response to cycles of freezing and thawing. Glaciated terrain occurs throughout much of Yukon Territory where the ash is widespread (Denton and Armstrong 1969) and provides the source of the fine-grained sediment.

Chemical alteration is extremely rare throughout the White River deposit; the lobes appeared as pristine and unweathered horizons almost everywhere features were noted or where samples were taken. Physical disruption of the ash layers has occurred to some extent in response to rootlets and vegetation in some ash layers. Recently uprooted spruce trees display ash intermixed with their root systems, implying some degrce of tolerance by the vegetative cover. Laterally extensive and discontinuous seams of charcoal with woody fragments were noted 


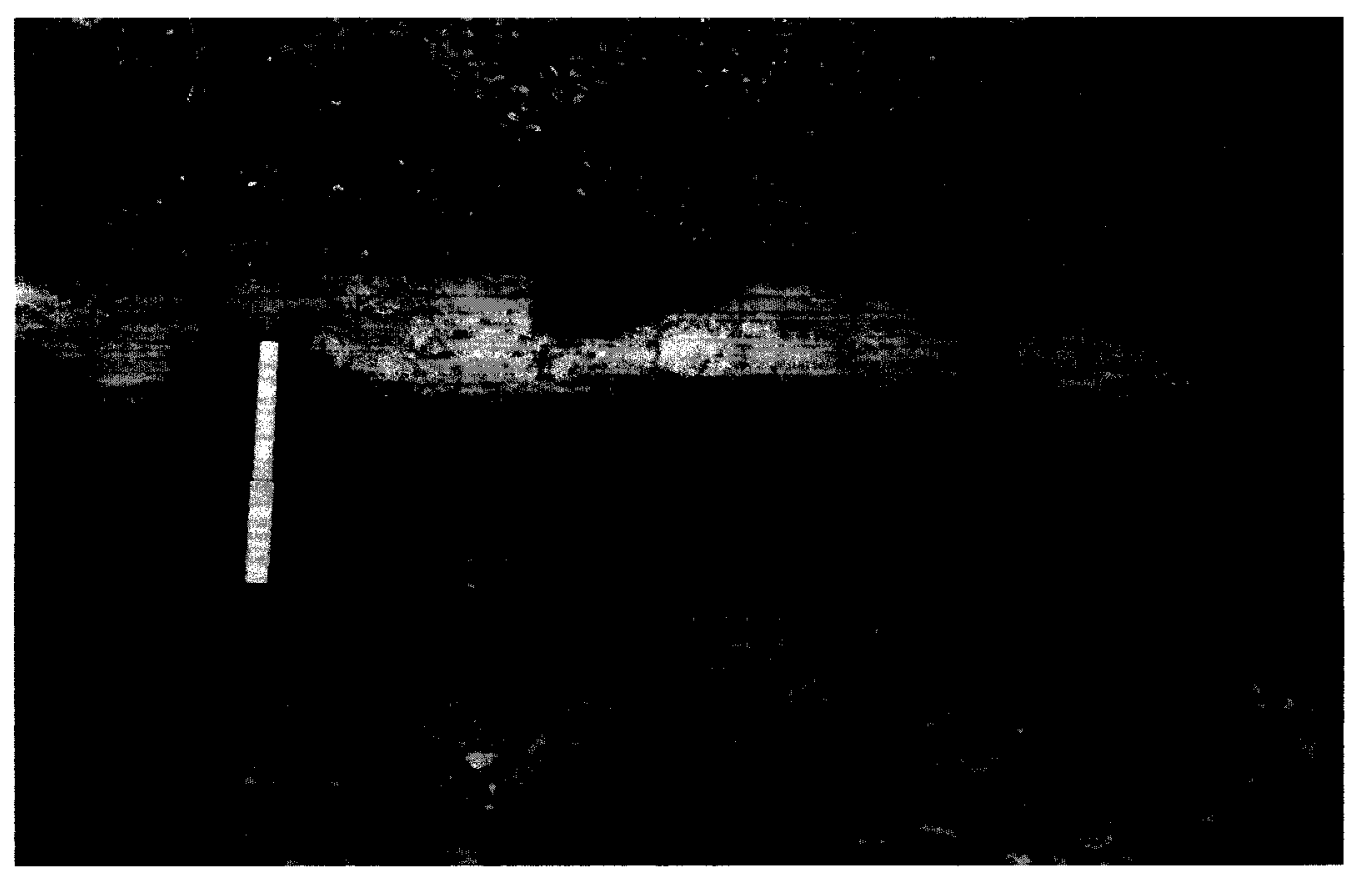

Figure 14: This distal layer of White River ash is located on an access road to Deadman Lake Campground in Tetlin National Refuge (Mile 26.2 or $\mathrm{km} 42.1$ on the Alaska Highway). Notice the irregular gradational upper contact, and the lower contact, which is sharp and prominent. 
above and within several deposits of east lobe ash (Figure 15). These layers are postulated to represent residue from vegetation burned by forest fires initiated by lightning during deposition of the east lobe ash or by prolonged dry spells the summer after the eruption was over. If the spruce forests that are characteristic of Alaska-Yukon did not invade the region until after the deposition of the east lobe ash, as Johnson and Raup (1964) and Workman (1974) suggest, then a large amount of dead underbrush coupled with a lack of moisture the following summer may have initiated forest fires throughout large portions of the open grasslands region. In some areas, the ash was redistributed through processes of water and wind erosion as well as slumping, and thus appeared to be much thicker than it would have been at the time of deposition (Figure 4). Resedimented ash is typically accompanied by ball and pillow structures, channel fill, and cross-bedding in addition to the usual grading and laminations (Figure 16).

Redistribution of the ash is consistent with the observation made by Crampton (1982) that the White River ash does not uniformly mantle the present regional topography, as would be expected from an ashfall deposit. The deposit geometry, akin to a topographically draped pyroclastic surge, is consistently thicker at lower elevations (i.e., valley bottoms and lower 


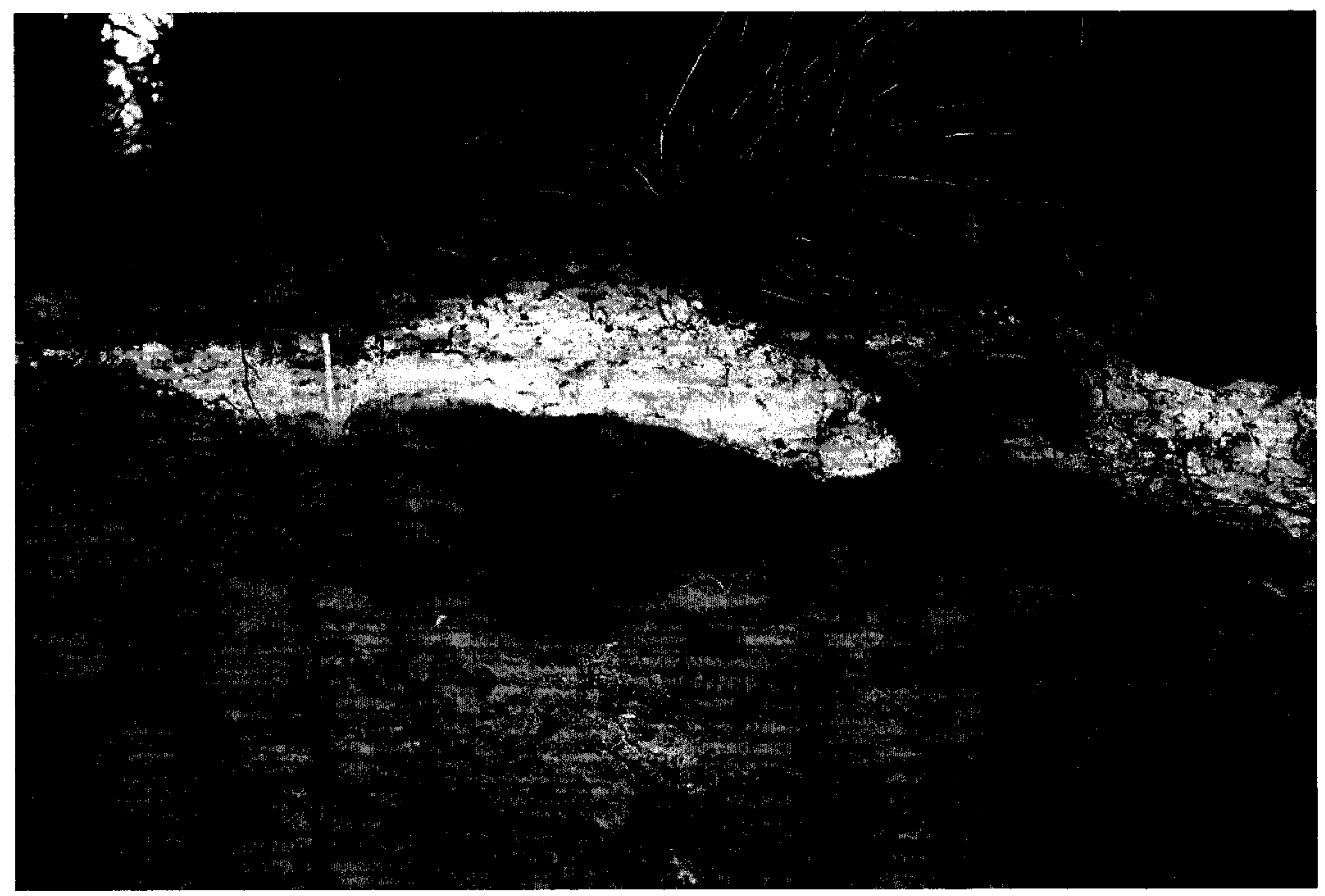

Figure 15: Thin discontinuous seams of charcoal, as seen along the bottom contact of this layer of east lobe White River ash, are common in deposits along the Alaska Highway. Pen for scale. 


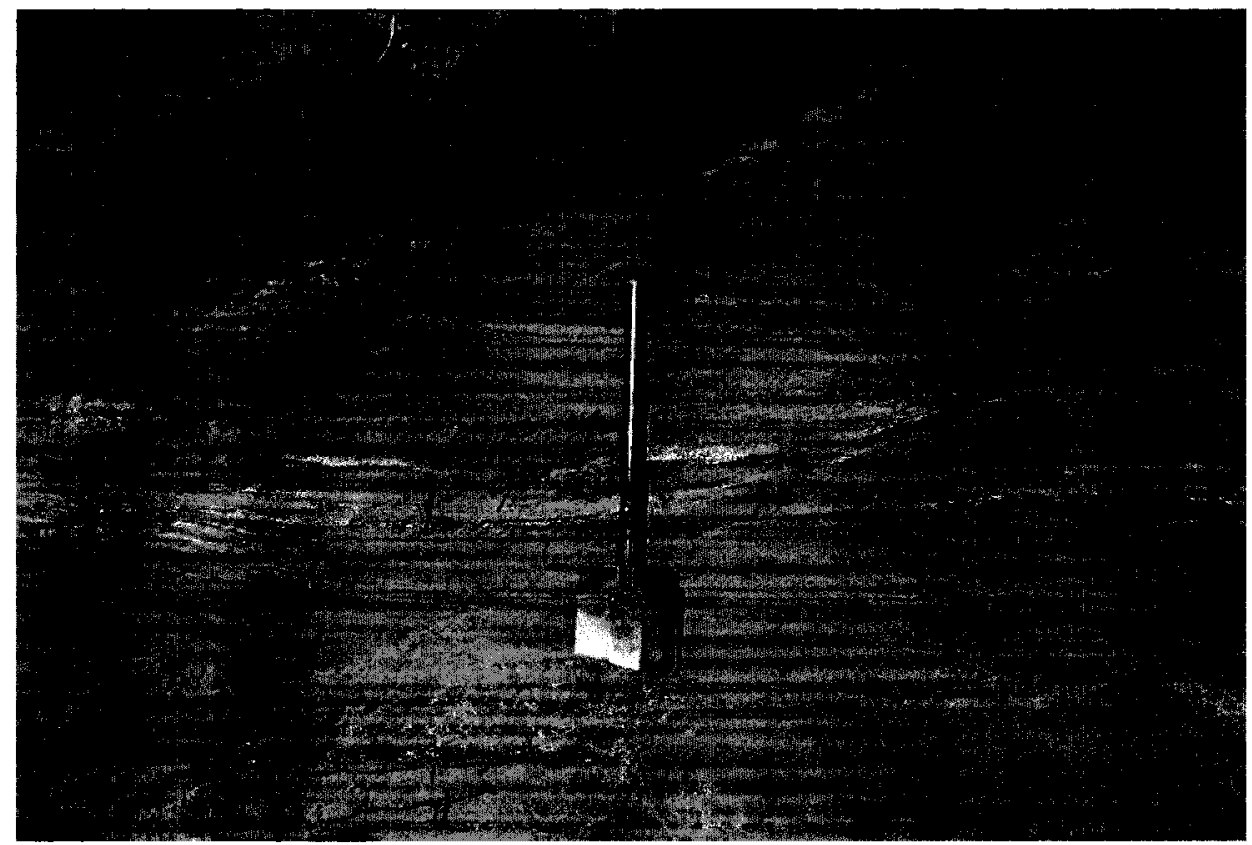

Figure 16: In some places, distal deposits of White River ash are redistributed through processes of water and/or wind erosion. These cross-beds are located along the Alaska Highway, near Johnston's Crossing, Yukon Territory. Shovel for scale. 
slopes) and thinner at higher elevations (i.e., hills and higher slopes). This concentration of ash in areas of lower elevation may have been augmented by water and wind erosion and redeposition after the ash was deposited. Crampton also noted that the concentration of ash is much thicker on west-facing slopes, indicating that initial distribution was greater on slopes facing Mount Churchill.

\section{Evidence for Late Fall- Early Winter Emplacement}

Understanding the timing of the east lobe ashfall has several important implications. First, the impact of such a large-magnitude eruption on vegetation, fauna, and the Athapaskan peoples subsisting on the land would had have more severe consequences in winter than at different times of the year (Workman 1979; Moodie et al. 1992). This is because the food supply at this time of year would have been limited, and the presence of snow during deposition of the east lobe ash would have rendered travel out of the region more difficult. Secondly, the eruption of east lobe White River ash is thought to coincide with the massive migration and expansion of the Athapaskan peoples. The timing of the eruption may support or dispute claims regarding ancient human history, the ecological impact of largemagnitude eruptions, and the differentiation of Athapaskan language. Lastly, this study provides a new approach and basis for studying the behaviour of ash and tephra during posteruptive processes. 
Sedimentological observations are herein described and interpreted from two deposits of distal ash located along the Alaska Highway in the Yukon Territory (Figure 17). The deposits are located within $100 \mathrm{~km}$ of each other, and are named for the regional water systems (Bock's Brook; Donjek River) they occur adjacent to. Interpretation of observations at both localities indicates that emplacement of the east lobe of White River ash occurred during the late fall or early winter.

\section{Bock's Brook}

Bock's Brook is a small gravel bed channel originating in the Kluane Range of southwest Yukon that drains into Kluane Lake, one of the largest and most beautiful lakes in the Yukon. The waterway crosses the Alaska Highway at the $1738 \mathrm{~km}$ highway marker, about $5 \mathrm{~km}$ south of Destruction Bay (Figure 17). This deposit was first noted during sampling of distal tephra along the Alaska Highway in 1999. Road construction in 2002-2003 has since modified the area originally examined. Current road construction may expose new deposits, but unfortunately, will cover or remove the deposit examined herein.

The Bock's Brook deposit is distinctive because it contains a prominent layer of pristine airfall ash which has been preserved in fluvially deposited beds (Figure 18). The ash layer is laterally 


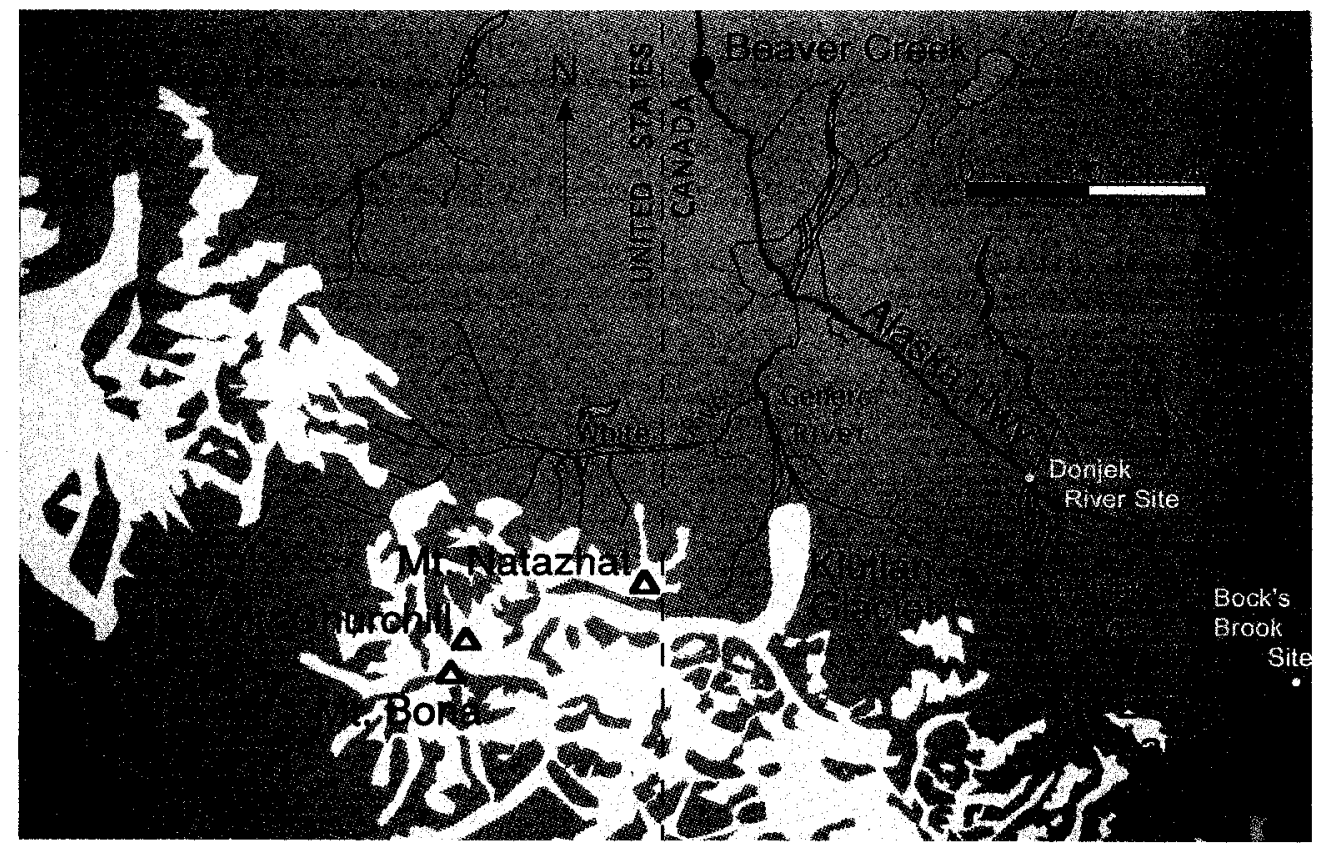

Figure 17: Evidence for late fall-early winter emplacement of east lobe White River ash was compiled from two sites, Bock's Brook, approximately $5 \mathrm{~km}$ south of Destruction Bay along the Alaska Highway, and Donjek River, approximately $200 \mathrm{~m}$ west of the Donjek River Bridge on the Alaska Highway. After Donaldson et al. (1996). 


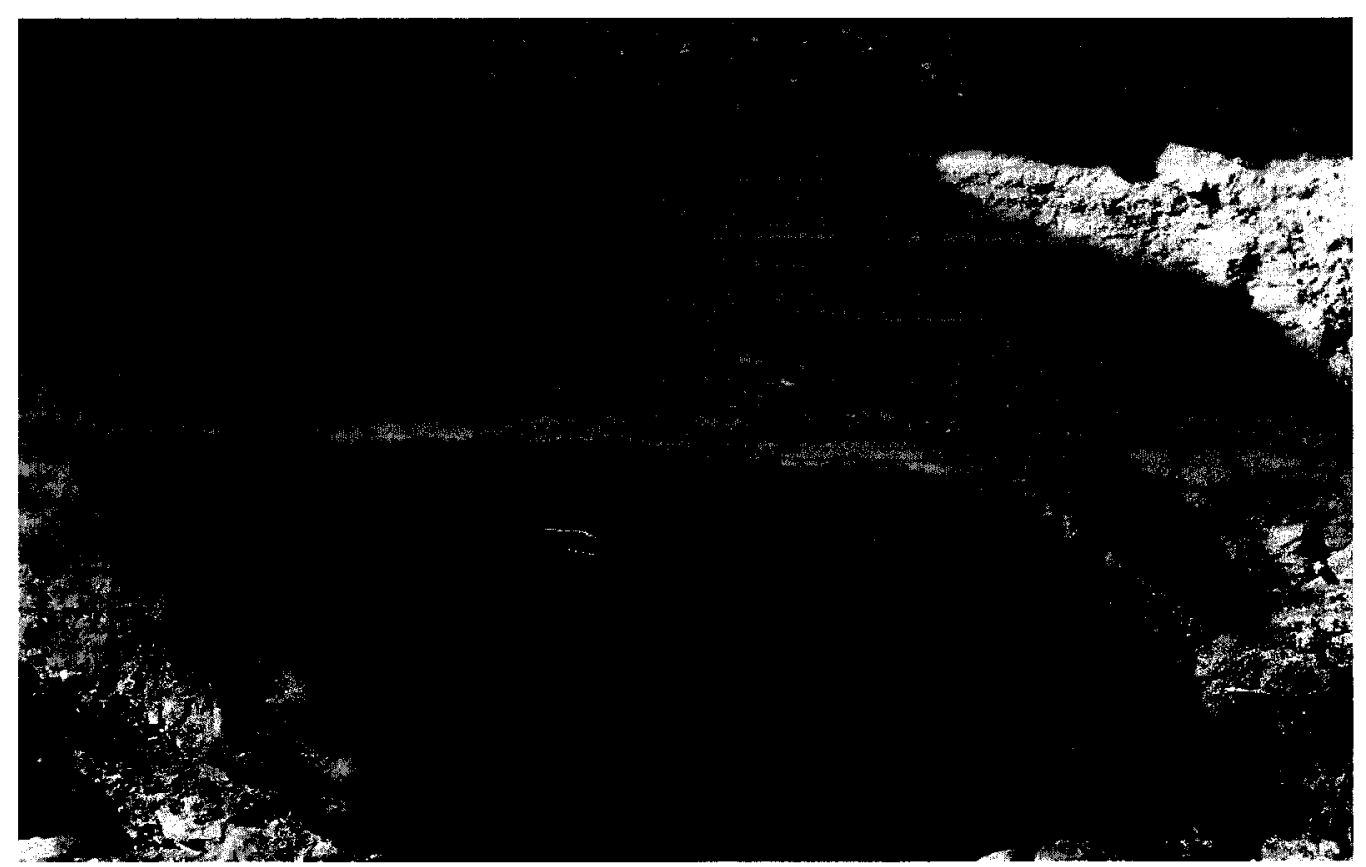

Figure 18: Overview of the ash layer, located in the south bank of Bock's Brook, Yukon Territory, $100 \mathrm{~m}$ west of the Alaska Highway, and approximately $100 \mathrm{~km}$ east of Mount Churchill, source of the ash. The unconsolidated ash layer in this section has an average thickness of $3.5 \mathrm{~cm}$, and is underlain and overlain by fluvially deposited sand and gravel. Swiss Army knife is $8 \mathrm{~cm}$ long. 
continuous for a distance of $8 \mathrm{~m}$ along the south bank of Bock's Brook, approximately $100 \mathrm{~m}$ west of the highway. It is also laterally continuous for 3-4 $\mathrm{m}$ in the same bank along the east side of the highway, at which point it become discontinuous and occasionally reappears downstream along both banks of the channel. Fluvial deposits above, below, and laterally adjacent to the tephra are predominantly composed of silt and gravel, with minor admixtures of sand and peat (Figure 19).

Four facies may be recognized in the Bock's Brook deposit according to the standard scheme initially suggested by Miall (1977; 1992; Figure 20). These include facies Gm, Ss, Flh, and C. Facies Gm is largely composed of clast-supported, crudely bedded sandy gravel. Clasts within this facies range from $3 \mathrm{~mm}$ to $4 \mathrm{~cm}$ in diameter and are crudely imbricated. A slight fining upward in facies Gm is locally apparent. Facies Ss consists of fine to very coarse sand that commonly contains pebbles. These sand layers typically occur as broad shallow scours within facies Gm and Flh. Facies Flh is composed of typical overbank sediments, including finely laminated sand and silt. Mud drapes over dropstones are common in facies Flh. Facies C occurs as thick deposits of peat, or as thin, discontinuous horizons in facies Flh. Channel scours filled with gravel (Figure 21), discontinuous layers of peat (indicating subaerial emergence), and the present geometry of the deposit next to a streambed, all point to these deposits originating in a fluvial environment (cf. Reading 1990). 


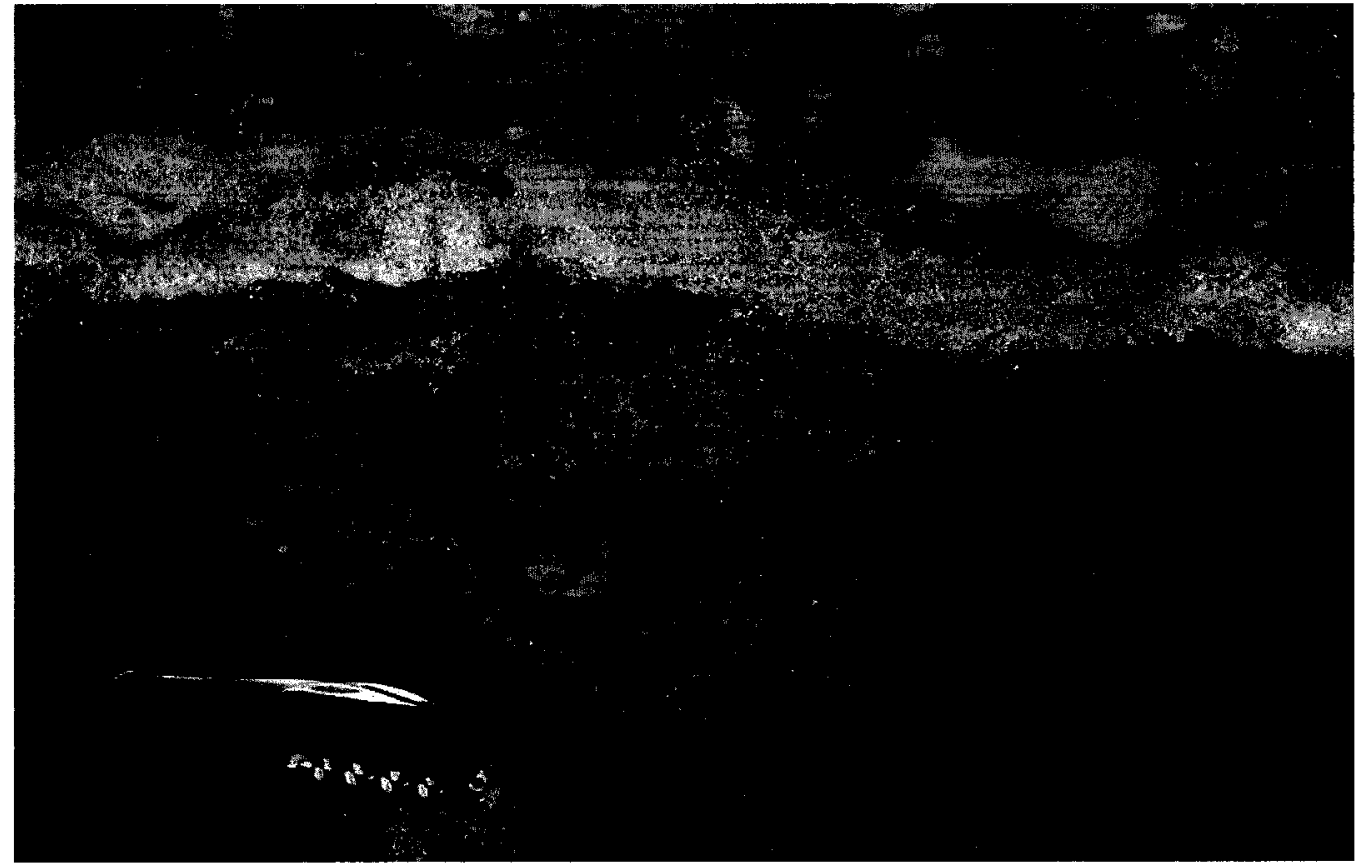

Figure 19: Close-up view illustrating compositionally homogeneous layer of ash at Bock's Brook between beds of fluvial gravel. The layer of fine-grained ash seen here must have been frozen before burial, in order to escape reworking by high-energy fluvial currents that were required to deposit the ash. Swiss Army knife is $8 \mathrm{~cm}$ long. 


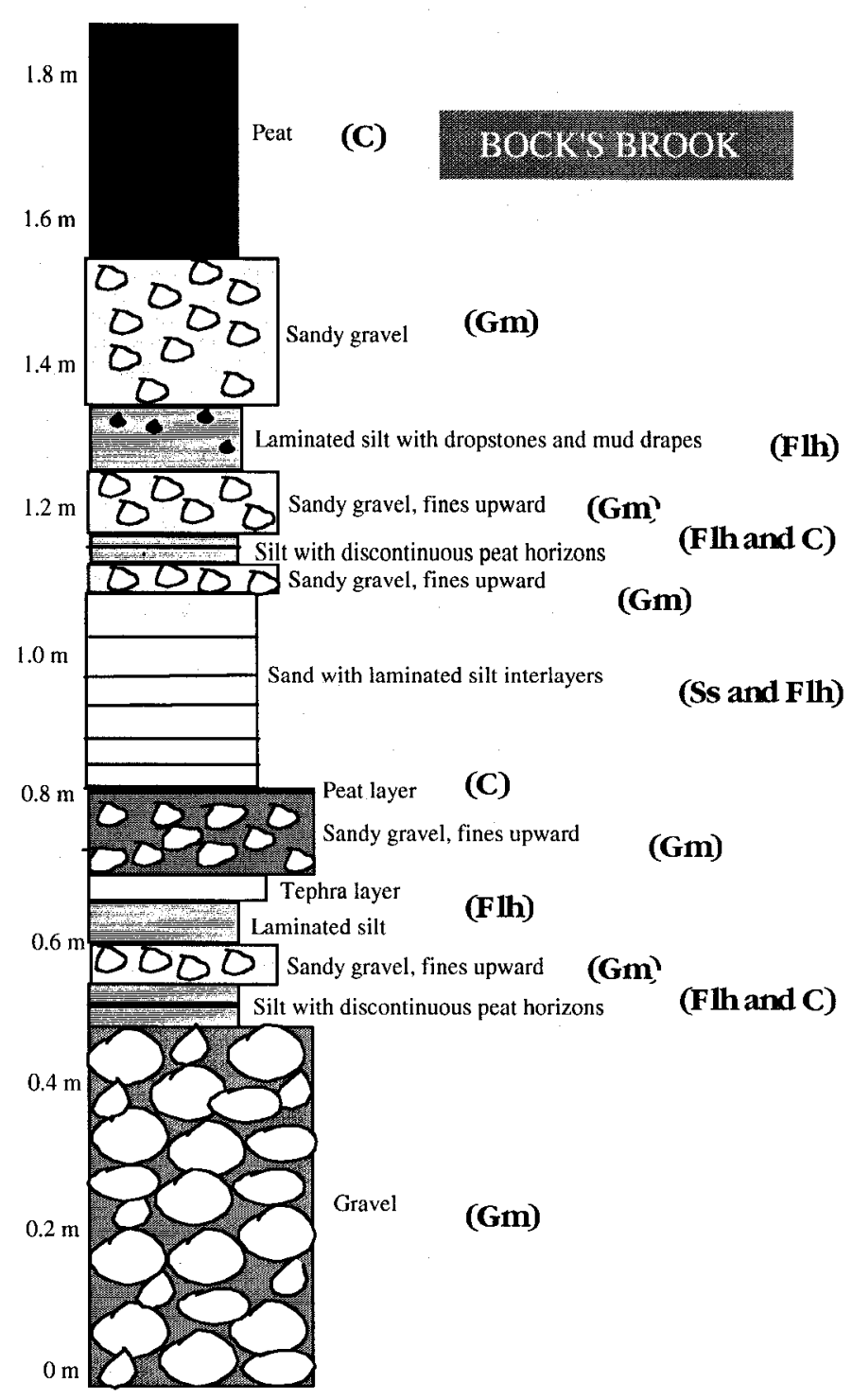

Figure 20. Stratigraphic section at Bock's Brook, Yukon Territory, along the Alaska Highway. The ash layer here has been preserved in fluvially deposited beds and is laterally continuous for a distance of 8 metres along the south bank of Bock's Brook. 


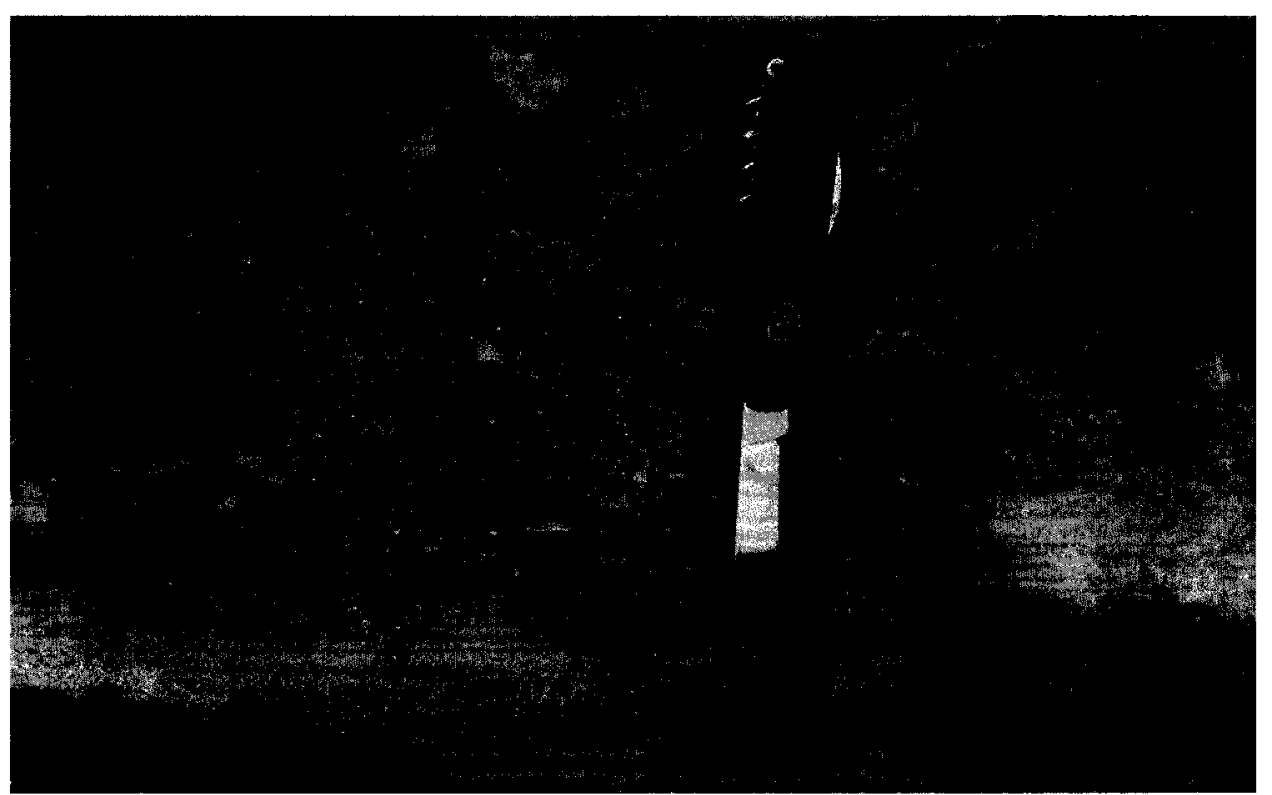

Figure 21: A gravel-filled scour, seen here at the tip of the Swiss Army knife, provides further proof that the Bock's Brook ash layer originated in a fluvial environment. 
The airfall tephra layer at this locality has a consistent thickness of $3.5 \mathrm{~cm}$ along its length and it occurs approximately $70 \mathrm{~cm}$ above the exposed base of the vertical section. It is composed of pristine white angular fragments of pumice, attesting to its origin as an airfall deposit. It is well defined and laterally traceable within this exposed succession of fluvial sediments (Figure 18). It also displays normal-graded bedding and faint horizontal laminations indicative of subaerial airfall origin. The largest particles within the tephra layer are granular, consisting of medium sand-sized pumiceous ash derived from the east lobe eruption.

\section{Donjek River}

Ice-cemented pumice clasts in the Donjek River section occur within a layer of fluvial silt in the north shore of the Donjek River, $200 \mathrm{~m}$ west of the Donjek River Bridge on the Alaska Highway (Figure 22). The Donjek River is a larger glacier-fed gravel bed channel system that drains the massive Donjek glacier and the smaller Spring and Steele Glaciers of the Kluane Range of southern Yukon. This site is less than $100 \mathrm{~km}$ north of Bock's Brook along the Alaska Highway.

The profile at Donjek River consists of glacial till which is overlain by fluvial silt (Facies Flh) and an upper unit of sandy to pebbly silt (Facies Ss; Figure 23). Ice-cemented pumice clasts are embedded within the upper $30 \mathrm{~cm}$ of the fluvial silt unit (Figure 24). These tephra clasts are presently consolidated by ice alone, consist almost entirely of medium sand-sized tephra 


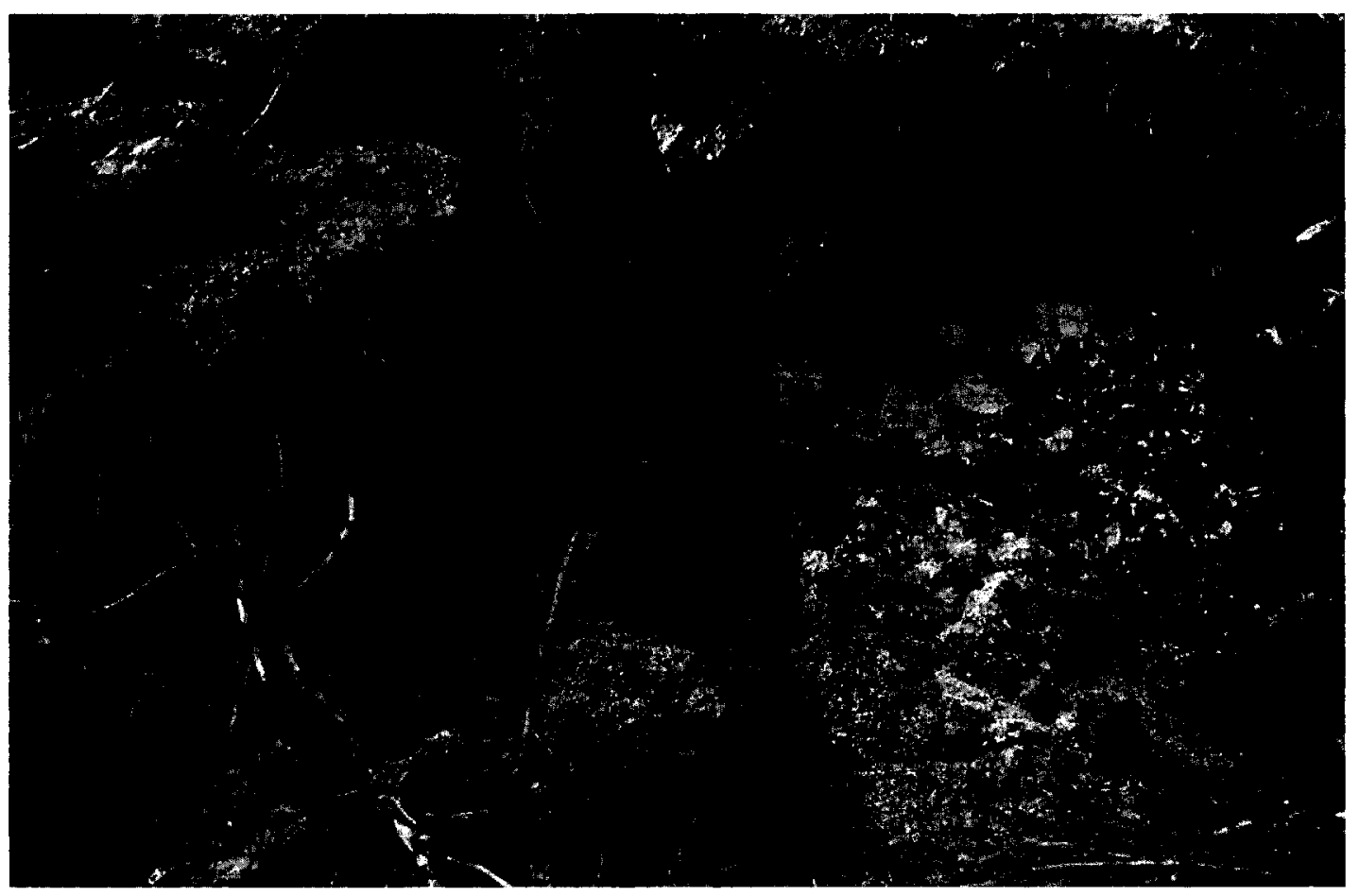

Figure 22: Overview of Donjek River section, Yukon Territory, located on the north side of Donjek River, Yukon Territory, $200 \mathrm{~m}$ west of the Donjek River Bridge on the Alaska Highway. Ice-cemented ash clasts occur within a bed of fluvial silt, seen here. A bed of sandy to pebbly silt overlies this unit. Shovel for scale. 


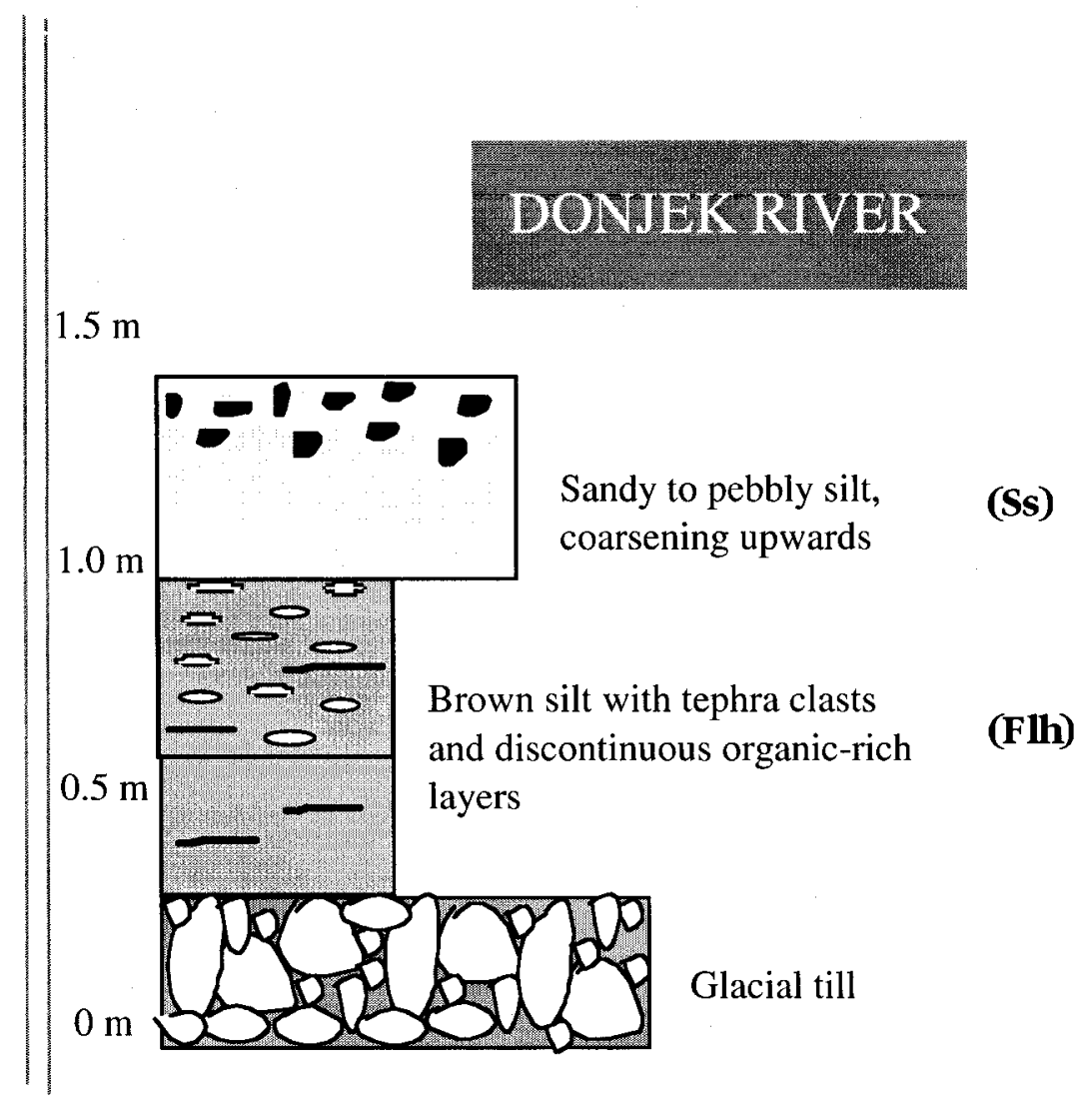

Figure 23: Stratigraphic section at Donjek River, Yukon Territory, along the Alaska Highway. Ash clasts are embedded in the fluvially deposited silt (Flh) layer. 


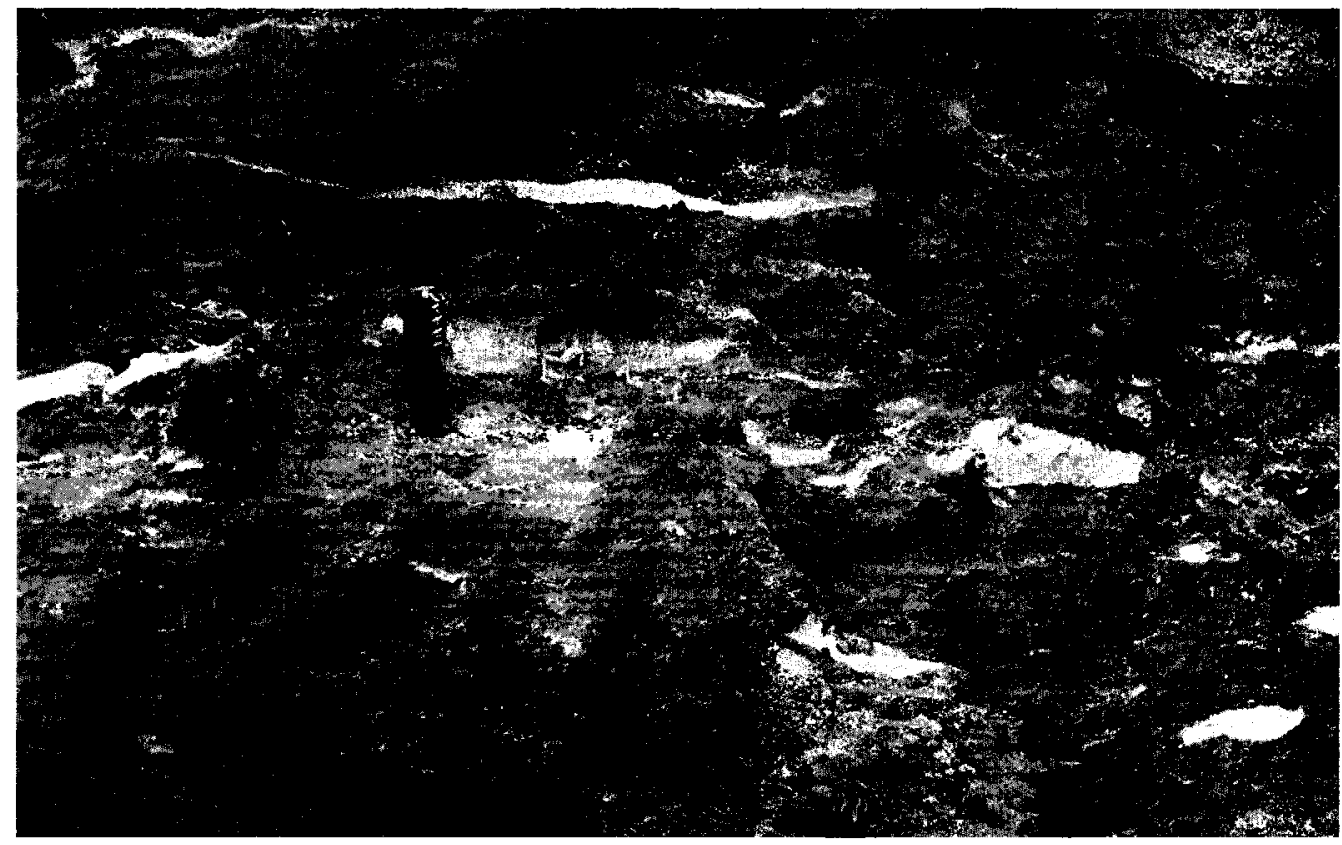

Figure 24: Angular ice-cemented clasts of unconsolidated ash are embedded in fluvial silt and sandy silt. The clasts of ash are compositionally homogeneous, granular, with faint parallel lamination, and are elongate subparallel to bedding shown by the silty matrix. Clasts are derived from frozen layers of airfall ash. Swiss Army knife is $8 \mathrm{~cm}$ long. 
particles, and are tabular, ovoid and irregular in shape. Internally the pumice clasts display faint horizontal lamination and are elongated subparallel to bedding. These clasts are inferred to have been originally deposited as a layer of airfall ash during the late fall or early winter.

\section{Discussion}

The Bock's Brook ash is inferred to have been deposited on a subaerially exposed overbank flood plain in the late fall or early winter, prior to the first major snowfall. Preservation of such a distinct layer of airfall ash directly below a gravel bed within a fluvial system requires that the ash had to have been frozen in order to escape reworking. Consequently, it follows that deposition of east lobe ash had to occur around the time of the fall-winter transition when it could be readily frozen, remaining so for the remainder of the winter season. In the spring, the still-frozen ash layer could have been subsequently buried by flood deposits of sand and gravel, sealing and protecting the layer against subsequent erosion. Interruptions in the lateral continuity of ash in the deposit may be due to cryoturbation or may represent areas where the ash was exposed on the surface and eroded away. Subsequent melting of ice in pore spaces of the ash layer also could produce postdepositional loading of epiclastic sediment along the boundaries of the ash layer.

The Donjek clasts were originally deposited as a layer of airfall ash during the late fall or early winter. Subsequent fragmentation of the layer and rounding of pumice clasts occurred during spring flooding when the layer was still ice-cemented. The compositional homogeneity and 
internal laminations of the Donjek River clasts indicate that they were originally deposited as an airfall layer of ash, comparable to the Bock's Brook layer. This ash layer was similarly deposited on a subaerially exposed overbank plain during the late fall or early winter, and was subsequently frozen over the remainder of the season. During spring flooding, fragmentation of the ice-cemented ash layer yielded the clasts now embedded in fluvial silt. To remain morphologically intact, the clasts had to have remained ice-cemented during fragmentation and transport, in order to survive abrasion before their subsequent burial in fluvial silt.

The preservation of ash as a laterally continuous layer (Bock's Brook) or as clasts embedded in fluvial silt (Donjek River) requires the formation of frost, or frozen water that condensed from some type of moisture. Water vapor in the ash layers could have arisen from humidity (e.g. a misty rain or wet snowfall that wetted the ground surface without significant runoff) or from condensation from the overlying snowpack or surrounding groundwater, as long as the surface ash layer was below freezing. It is more likely that moisture originated from condensation, as the typical Yukon climate in the Bock's Brook and Donjek River area is dry. Moisture exchange between snowpack and the underlying ash layer is inferred to have occurred during the formation of névé, during which melting occurs (Marsh 1987) or during a few sunny days after the eruption to cause surface melting and downward percolation of water. Alternatively, Zhang et al. (2001) have written that frozen soil may be thawed quickly after a consistent snow cover is established. This observation suggests that freeze-thaw cycles may have been responsible for moisture exchange between the snowpack and the White River ash layers. 
Stratigraphic evidence of ice-cemented ash from deposits at Donjek River and Bock's Brook therefore indicate that the east lobe eruption of ash must have occurred during the late fall or early winter, in order for the ash to be preserved as it is today. In some cases, sedimentological observations of layers like these can be used with confidence to determine the season of eruption. However, as with any interpretation, it is reasonable to seck reinforcement through other observations and methods. Further observations that support or dispute late fall or early winter emplacement for the east lobe of White River ash are discussed next.

\section{Supporting Evidence for Winter Eruption}

The White River ash is distributed within two petal-shaped lobes to the north and the east, suggesting that strong winds from the south and from the west were in effect respectively during the two eruptive events. Hanson (1965) previously suggested that the east lobe eruption occurred in winter, because of modern high-atmospheric winds that blow towards the east in winter (January) and towards the north in summer (July) in the Alaska-Yukon region (Hanson 1965; Workman 1979). Assuming that the same wind patterns prevailed in the past, one might suggest that the probabilities favored a winter emplacement of the east lobe ash and a summer emplacement of the north lobe ash. However, this depends very strongly on cyclical weather patterns, which are often tenuous and unpredictable at best. 
The exceptional preservation of White River tephra on steep slopes throughout the region may provide evidence that the east lobe ash was erupted during the winter season (Hanson 1965). In their 1969 publication, Lerbekmo and Campbell noted the anomalous occurrence of thick deposits of ash on slopes up to 40 degrees. This observation led the authors to suggest that it may have been snowing during the White River eruptions, with the ash compacting under a snow load rather than being washed off steep slopes in a torrential rain. Preservation of ash on steep slopes, then, might raise the possibility that the ash accompanied an early winter snowfall, ensuring maximum preservation of the deposit (which is exceptionally wellpreserved) during the spring thaw.

The distribution, volume, grain size, and composition of the White River deposit suggests that both lobes were deposited from incredibly powerful eruptions of Plinian magnitude. Events of this magnitude are extremely destructive, defined by Walker and Croasdale (1971) as "exceptionally [powerful] continuous gas blast eruption[s] which eject pumice copiously." Although the White River ash displays several characteristic features of a Plinian-style eruption (i.e. it is widely dispersed over a large geographical area, composed almost entirely of juvenile pumiceous material, and displays compositional homogeneity throughout the thickness of the deposit; Walker 1981), the absence of coarse pumice throughout the deposit, along with a low fragmentation index, is contrary to this type of eruption style (Downes 1979). This may mean that the White River eruptions were not Plinian events or that snow and/ or ice interaction at the summit of the volcano played an important role during eruption of the ash (Domnes 1979; 
Walker 1981).

Additional evidence for a winter emplacement is provided by the tremendous local thickening of east lobe ash in a roadside cut along a creek on the north side of the Alaska Highway, approximately $100 \mathrm{~km}$ from Ross River. The deposit is horizontally laminated and compositionally homogeneous, with only minor intermixing of silt. The deposit reaches a thickness of nearly $1.5 \mathrm{~m}$. It displays multiple layering with low-angle cross-beds, ripples, and channels, which collectively rule out thickening due to either road construction or wind resedimentation alone. The most probable way to produce such thickening of essentially pure ash would appear to be through spring runoff over snow cover, immediately after a winter eruption.

Recent evidence from Froese (2007) suggests that the east lobe ash was deposited during the summer, possibly in late July or early August of $797 \mathrm{AD}$, because of evidence in Greenland ice cores and in historical records from French astronomers and the Chronicles of Theophanes that coincides with a large eruption at approximately this time. Evidence from the Greenland ice cores suggests that the east lobe ash was responsible for carrying ash as far east as Greenland; the historical records indicate that sunsets were affected during the summer. It is possible that this event (represented in the Greenland ice cores) could have occurred prior to deposition of ash at Bock's Brook and Donjek River, particularly if there were multiple pulses of airfall. Evidence of multiple airfall layers are preserved within stratigraphically continuous 
units along the Alaska Highway, and in the thick ashfall accumulations along White River, just below the confluence with the Generc River (Figure 25).

It is possible that the ash at the Bock's Brook and Donjek River localities was deposited during the summer months and remained undisturbed until the late fall or early winter, at which point it froze until it was covered the following spring by post-depositional gravels. This would require conditions free of major rainstorms or windstorms between the time of summer deposition though to the time of freezing in late fall. A single rain or windstorm would have modified the thickness of the unfrozen ash layer when it was deposited on a vegetation-free floodplain. The lateral continuity of the ash layer, its uniform thickness, and lack of depositional irregularities suggests that it was not subjected to any modification by wind or rain storms. The present frequency of rain and wind in August and September in Yukon and Alaska suggests that significant post-depositional modification via wind or rain would have occurred during a comparable summer to fall transition (Environment Canada 2007a and 2007b).

\section{Probable Impact}

The region affected by deposition of the White River ash ca. 1147 years B.P. (Clague et al. 1995) is within the territory of several indigeneous groups including the Han, Northern Tutchone, Southern Tutchone, and Upper Tanana Athapaskans (Workman 1974). The most 


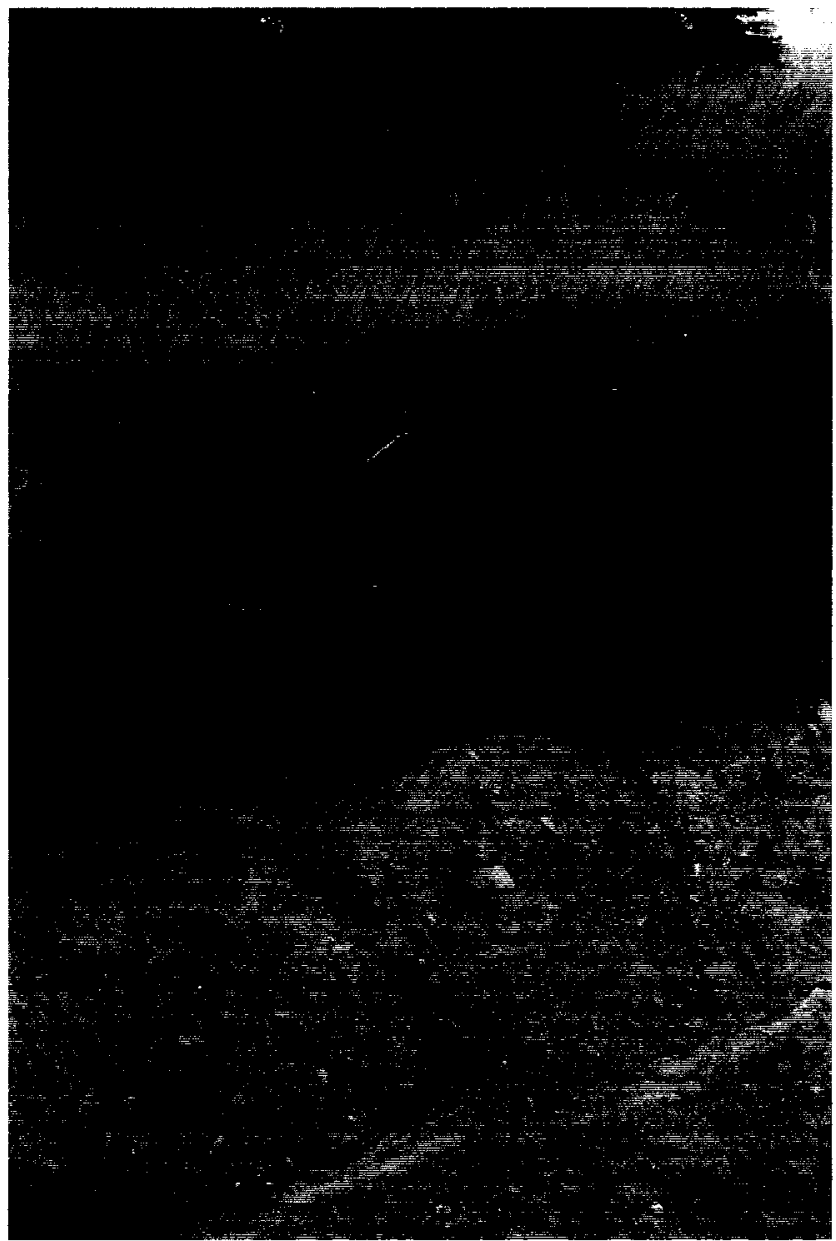

Figure 25: Multiple airfall layers are preserved within stratigraphically continuous units along the Alaska Highway, as seen here, as well in the thick ashfall accumulations along the White River just below the confluence with the Generc River. At least three distinct horizons of ash are present at this location. 
recent distribution of the ash (Robinson 2001) indicates that some of the territory occupied by the Tagish and the Kaska would also have been affected by fine amounts of ashfall. Deposition of the north lobe ash, ca. 1887 years B.P. (Lerbekmo et al. 1975) would primarily have affected the territory of the Upper Tanana, Han and Gwich'in Athapaskans to the north.

The Athapaskans are a widespread group of indigeneous peoples across Yukon and Alaska who are united by a closely related language. Workman (1974) has developed one of the few Athapaskan cultural sequences for the Aishihik-Kluane Lake area adjacent to the YukonAlaska border. During the time of the White River eruptions, it is likely that many Athapaskan groups and tribes were thinly scattered across southern Yukon and Alaska. Workman (1979) estimated that the population density within a much smaller area of ashfall (based on the isopach map produced by Lerbekmo et al. 1975) was one individual per 250 $\mathrm{km}^{2}$ to one individual per $100 \mathrm{~km}^{2}$. The Athapaskans traditionally moved from season to season to hunt, fish, trap, or trade with neighboring groups. Paleoenvironmental data indicates that much of the area was inhabited by moose, caribou, mountain sheep, and various other small mammals as well as birds and freshwater fish, although salmon was absent (Workman 1979). Vegetational data indicates that the area was dominated by grasslands and not by the spruce forests like those characterize the region today (Johnson and Raup 1964; Workman 1974; 1979). 
During the Neoglacial, there was a resurgence of ice-dammed lakes due to reblockage of the Alsek River (Workman 1974; Clague 1982). This blockage could have contributed to waterfilled areas throughout much of the Northern and Southern Tutchone territories as well as the absence of salmon runs from the Pacific (Workman 1974). Because of these conditions, Workman suggested that Shakwak and Dezadeash valleys were not occupied by the Tutchone during deposition of the east lobe ash. In addition, much of the Upper Tanana territory around Mount Churchill was also unoccupied due to the presence of the rugged and glaciated St. Elias Mountains (Workman 1979). The Northern and Southern Tutchone, whose territory might have already been diminished due to the presence of these icedammed lakes, would likely have endured even greater stress during deposition of the east lobe ash ca. 1147 years B.P.

Effects of the White River eruptions on the homelands of the Athapaskan peoples are inferential and are based on the limited information collected to date and the impact of more well-known historical eruptions (Workman 1974) such as Novarupta (1912; Alaska) and Krakatau (1883; Indonesia) which were similar in size, magnitude, and nature of eruption to the White River events. It is likely that the ash fell over a period of days (Workman 1974) to the east (ca. 1147 years B.P.) and north (ca. 1887 years B.P.) based on current patterns of ashfall distribution. During the eruption of Novarupta in Alaska in 1912, nearly $30 \mathrm{~cm}$ of ash fallout $170 \mathrm{~km}$ southeast of the volcano was accompanied by intermittent darkness, ashinduced lightning strikes, ash avalanches, nil visibility, ash-filled air which caused difficulties 
in breathing and eye, throat, and respiratory problems, and the destruction of plants, water, and food supplies, rendering most of the area a biological desert (Fierstein and Hildreth 2000). Similar effects would be expected during both White River eruptions, and the ashfalls may have been accompanied by rain, snow and noxious fumes (Workman 1979), rendering the above effects even worse. Any Athapaskans living close to the volcano would likely be in total darkness for days, making travel out of the region nearly impossible (Workman 1979). The blast from the east lobe eruption may have been heard several hundred kilometers away from the source, judging by the observations during the eruption of Krakatau in 1883 (Moodie et al. 1992). The height of the eruption clouds (30-35 km; Downes 1979) were sufficient to have entered the stratosphere (Workman 1974), and would have affected global climate and weather patterns. Unusual light effects, such as those produced after the eruption of Krakatau in 1883 (Simkin and Fiske 1983), may have included exceptionally intense red skies, and a blue-green coloration of the moon for years after the eruptions.

The White River eruptions would have had a devastating impact on the way of life of indigeneous peoples. Most of the areas covered by ashfall would have become biological wastelands (Workman 1974, 1979), unable to support animals, vegetation, or humans for years to decades after the eruptions occurred. If, as postulated here, the younger eruption of ash (ca. 1147 years B.P.; Clague et al. 1995), which was substantially greater in magnitude than the older eruption, did occur at the onset of winter, a limited food supply would have 
wrought an even greater hardship upon the Athapaskan peoples. In addition, as previously discussed, particular indigeneous groups (including the Northern and Southern Tutchone) may have endured greater stress during the winter months, if their territory was already limited due to the presence of ice-dammed lakes (Workman 1974).

\section{The Athapaskan Migration}

Emplacement of the east lobe ash may have played a role in the migration of certain small groups of Athapaskans to the Pacific coast and American southwest (including the Navajos and Apaches). However, the history of the Athapaskan peoples has been difficult to trace. Several archaeological sites in Alaska indicate the existence of prehistoric Athapaskans, but few clues as to the origins and connections of the historically known ethnographic Athapaskans have been discovered. Currently, there are three different migration hypotheses, outlined below, that have been proposed to account for differentiation of the Athapaskan language.

The Athapaskan family of languages is one of the most widely diffused language groups in North America (Fowler 1977) and is a branch of a larger linguistic group, the AthapaskanEyak in the Yukon and Alaska. There are 23 recognized geographical subdivisions of the Athapaskan language family. Subdivisions within interior Alaska and northern Canada (British Columbia, Alberta, and Saskatchewan) are referred to as Northern Athapaskan

(Krauss and Golla 1981); Athapaskan language has also differentiated into areas in 
Washington, Oregon, northern California and the American southwest, constituting the A pachean languages which include Navajo, Kiowa, Lipan and various others. Some authors believe that there is enough of a genetic (linguistic) relationship between the languages of Tlingit, Athapaskan, and Haida to group them into a single entity called Na-Dene, but other authors disagree (Krauss 1972).

Based on linguistic evidence, the Athapaskan and Eyak languages were both present in Alaska and the Yukon by $6000 \mathrm{BP}$, and had differentiated into proto-Athapaskan and protoEyak by $3500 \mathrm{BP}$. Athapaskan languages differentiated even further around $2500 \mathrm{BP}$ (Kraus 1990) in Alaska, Yukon, and possibly northern British Columbia. By 500 AD, Athapaskan expansion had occurred westward into Alaska and southward into southern and central British Columbia. Later movement eastward along the Mackenzie river drainage and the east side of the Rocky Mountains resulted in Apachean and Pacific differentiation of the Athapaskan language.

The spread of the northwest microblade tradition in the southwest Yukon c. 7000 BP has been correlated by some authors with the Na-Dene speaking people, and the initial differentiation of the Athapaskan language. However, this theory has not been widely accepted. Clark (1992) proposed that the ancestral Athapaskans belonged to the Northern Archaic and Cordilleran traditions based on the Healy archaeological site whereas Cook and McKennan (1970) have proposed that the recognizable Athapaskan cultural pattern began in 
the northern interior of Alaska with the major changes that preceded the Northern Archaic tradition 6000 years ago.

The emplacement of east lobe White River ash has also been held responsible for the displacement of Athapaskan peoples. Workman (1974) suggested that at least several hundred people would have moved north or south (away from the areas of thickest ash deposition) into areas occupied by other indigeneous groups. This hypothesis correlates with the appearance of Athapaskan tools in the Brooks Range, as well as other generalized implements of the Athapaskan tradition. Workman (1979) also suggested that the biological wasteland created by the eruption may have prompted the movement of the Athapaskans to the American southwest.

A lack of archaeological data precludes determination of which of the above hypotheses is correct. Additional archaeological research is needed in areas peripheral to and outside the ashfall region in order to establish culture change, small-scale population movements, thereby establishing this period to have been a time of flux (Workman 1979).

\section{Conclusions}

Recent evidence from a frozen layer of airfall ash near Destruction Bay, (Yukon Territory) and from ice-cemented ash clasts near the Donjek River (Yukon Territory) illustrate that eruption of east lobe ash probably occurred during the late fall or early winter. The study of 
previously unexamined proximal sections of White River terraces (Chapter 4) also reveals the occurrence of similar still-frozen ice-cemented pumice clasts, providing direct evidence for the transport of clasts reworked from previously deposited pumice accumulations as postulated in this chapter. These observations hold significance for studies of ancient deposits in which the origin for such clasts might readily go unrecognized, especially where the original ice cement has been replaced by diagenetically introduced cement. A key to recognition of clasts formed in this fashion is truncation of grains at the margins of the clasts. Although evidence of peripheral abrasion is readily apparent for clasts in which the component grains are of lapilli size, truncated grains could easily be overlooked in clasts composed of finer-grained volcanic ash.

Precise timing of the east lobe eruption is essential for elucidation of the cultural and environmental effects of this volcanic event. The impact of such a large-magnitude eruption on vegetation, fauna, and the Athapaskan peoples subsisting on the land would vary during different times of the year. In addition, the effect of landslides, mudslides, and erosion in proximal and surrounding regions would also vary according to the season in which the eruption occurred. Such information is essential in volcanic hazard assessment of the region, because pyroclastic activity in ice-covered regions can cause sudden melting of glaciers and snowfields, resulting in catastrophic flooding of surrounding drainage areas as demonstrated by the 1990 eruption of Mount Redoubt in Alaska (Major et al. 1990). 
Until now, few methods have been developed to research the connections between natural events and cultural shifts. More integrated work is needed in this area to further clarify natural and historical events. Future palynological studies may help to confirm the season of deposition for the east lobe of White River ash. The method outlined in this chapter will hopefully add to the ways in which we can begin to understand how exteme volcanic events have impacted prehistoric peoples (cf. Brayshay and Grattan 1999). Alone, evidence from archaeology, anthropology, biology, paleoenvironmental studies, or geology is not enough to identify subtle or short-term impacts of large volcanic eruptions, or may be contradictory. However, when information from these disciplines is combined, a broader and more comprehensive view of short-term impact from large-scale volcanic events can be attained, even though it may not be possible to reconstruct the exact nature of the environmental and social impacts (cf. Brayshay and Grattan 1999). 


\section{Chapter 3: Textural Analysis of Proximal Deposits}

\section{Introduction}

In the past 2,000 years Mount Churchill $\left(61^{\circ} 25^{\prime} \mathrm{N}, 141^{\circ} 70^{\prime} \mathrm{W}\right)$ has erupted twice, producing an estimated $27 \mathrm{~km}^{3}$ of ash (Robinson 2001) in northern Canada and Alaska. This deposit, collectively known as the White River ash, covers over $540,000 \mathrm{~km}^{2}$ of the Northwest Territories, Yukon, Alaska and northern British Columbia (Robinson 2001; Figure 1). Recent work by Jensen and Froese (2006) has expanded the distribution of the White River deposits, suggesting that the northern lobe of ash covered approximately $100,000 \mathrm{~km}^{2}$ and the eastern lobe covered approximately $500,000 \mathrm{~km}^{2}$. The deposit is distributed into elongate lobes based on prevailing wind directions during two eruptions ca. 1887 (north lobe; Lerbekmo et al. 1975) and 1147 years B.P. (east lobe; Clague et al. 1995). The White River eruptions are comparable in size and magnitude to some of the largest eruptions in human history, including Krakatau (1883) and Katmai (Novarupta, 1912; Table 1).

Both lobes of White River ash are unconsolidated and composed of glass, plagioclase, hornblende, hypersthene, and magnetite (Lerbekmo and Campbell 1969) with minor amounts of biotite (Table 2). Distal deposits (more than $50 \mathrm{~km}$ away from the source volcano) are commonly used as chronostratigraphic markers because of their intense white color and location in the soil horizon (Figure 4). In most areas, distal deposits of ash have an appearance that is similar to a layer of granular snow (Figure 14). Most of the deposit is moderately sorted, 
with angular to subround fragments of ash and pumice that range in size from clay to granulesized particles, depending on the distance from Mount Churchill. In the zone of overlap, the east lobe ash $(0.125-0.25 \mathrm{~mm})$ lies stratigraphically above the north lobe ash $(0.25-0.5 \mathrm{~mm}$; Figure 4). The difference in grain size between the two lobes reflects the more intense magnitude of the younger eruptive event (Downes 1979).

The proximity of distal ash deposits to roadways and communities in northern Canada and Alaska has resulted in a wealth of literature on its distribution and composition as well as the character of the White River eruptions (Schwatka 1885, Dawson 1888, Hayes 1892, Moffit and Knopf 1910; Capps 1915; Johnston 1944; Bostock 1952; Berger 1960; Fernald 1962; Stuiver et al. 1964; Hanson 1965; Lerbekmo et al. 1968; Lerbekmo and Campbell 1969; Lerbekmo et al. 1975; Downes 1979, 1985; McGimsey et al. 1990; Clague et al. 1995; Donaldson and Mueller 1993, 1994; Donaldson et al. 1995, 1996; Preece 1997; Robinson 2001). Comparatively, very little work has been done on the proximal ash deposits that occur in the St. Elias and Wrangell Mountains (Donaldson and Mueller 1993, 1994; Donaldson et al. 1995, 1996). This region contains numerous high-reaching peaks and icefields that are drained by valley glaciers. Proximal tephra (less than $50 \mathrm{~km}$ away from the source volcano) occurs in valleys or embayments among surficial deposits (alluvium, colluvium, landslides, talus, glaciofluvial deposits, and a variety of moraines) away from the erosive reach of glaciers. In places near the source volcano, the ash is $50 \mathrm{~m}$ thick (McGimsey et al. 1990; Richter et al. 1995a). 
Proximal deposits of White River ash tend to be concentrated along the margins of valley glaciers that emanate from the source volcano. Mount Churchill $(4,766 \mathrm{~m})$ is a relatively young stratovolcano located approximately $25 \mathrm{~km}$ west of the Yukon-Alaska border $\left(61^{\circ} 25^{\prime} \mathrm{N}\right.$, $141^{\circ} 70^{\prime} \mathrm{W}$ ) in the St. Elias Mountains (Figure 2). Nearby Mount Bona $(5,005 \mathrm{~m}$ ) may be part of the same volcanic complex, blasted away during the last eruption of White River ash. The Bona-Churchill col supports the Klutlan and Russell Glaciers to the east and north, and the Hawkins Glacier to the south. The 2-km-diameter vent on Churchill opens to the northeast and is reminiscent of a possible caldera structure (McGimsey et al. 1990). The majority of proximal deposits have been found along the 82-km-long Klutlan Glacier (Field 1975; Driscoll 1980), which flows to the east across the international boundary and then north to form the headwaters of the Klutlan River in Canada. Proximal deposits are also found along Natazhat Glacier, to the north of Klutlan Glacier, and Russell Glacier, which flows to the north to form the headwaters of the White River system.

Along Klutlan Glacier, proximal deposits of White River ash occur as locally resedimented terraces approximately 100 meters above the present surface level of the ice (Donaldson et al. 1996). These terraces occur discontinuously along the margins of Klutlan Glacier for up to 30 kilometers east of Mount Churchill (Figure 26). The terraces display steep $\left(>30^{\circ}\right)$ angle of repose margins and flat tops, and may be up to $20 \mathrm{~m}$ in height. Most terraces are composed of interlayers of ash and lapilli along with clay and lithic-rich layers (Figure 7). In addition, an apron of proximal tephra occurs adjacent to the upland rugged mountains, with the fan apex 


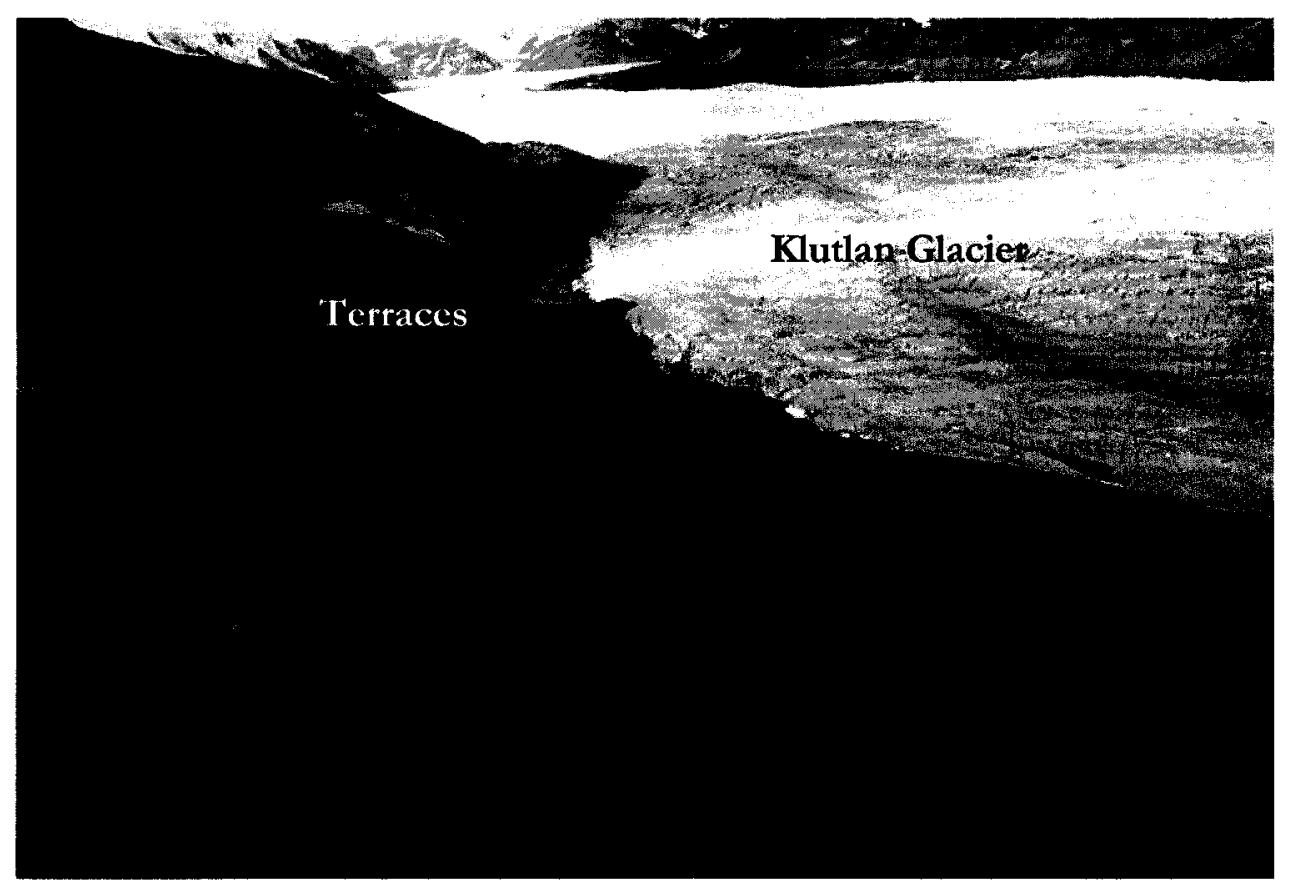

Figure 26: Pumice terraces located discontinuously along Klutlan Glacier, Yukon Territory. These terraces are horizontally laminated, with flat tops and a thickness of up to 20 meters. 
located at the terminus of Klutlan Glacier (N61'36.516', W140 $39.522^{\prime}$; Figure 9). It is speculated that this apron of volcaniclastic debris and the resedimented terraces along Klutlan Glacier were deposited when hot volcanic material mobilized snow, ice, and volcanic debris.

To date, two studies have focused on proximal deposits of White River ash (Switzer 1996; Donaldson et al. 1996). The study by Switzer (1996) revealed two prominent textures (airfall and reworked) in the proximal deposits. The study by Donaldson et al. (1996) focused on the age, origin, composition, stratigraphy, and depositional history of a terrace on the north side of Klutlan Glacier, approximately $40 \mathrm{~km}$ east of Mount Churchill (and almost due north of Mount Natazhat, which was earlier thought to be the source of the White River ash). These authors summarized the principal sedimentological characteristics of this terrace (including horizontal laminations, cross-bedding, asymmetric ripples, normal and inverse grading), established the composition and provenance of the constituent volcaniclastic materials (Table 2), and suggested that the terraces along the margins of Klutlan Glacier accumulated in flowing water, at a time between, or during the last of the two major eruptions of Mount Churchill (represented distally by east and north lobes of ash). They postulated two hypotheses for elevation of the terraces related to the present level of Klutlan glacier: a. substantial melting of Klutlan glacier since the terraces were deposited, or b. thickening of Klutlan glacier in response to surging and increased heat flow related to volcanic activity. 


\section{Purpose of This Study}

The evidence to date indicates that various depositional processes must have been in play during emplacement of proximal and distal deposits of White River ash ca. 1887 and 1147 years B.P. (Lerbekmo et al. 1975; Clague et al. 1995). The focus of this chapter is to examine the textural features of proximal White River deposits to provide insight on the processes that lead to their transport, deposition, and reworking. This work builds upon the facies analyses completed later in this dissertation and aims to further elucidate general and analogous features of the terrace deposits as well as depositional environments. Although distal deposits of the White River ash have been well studied, many questions still remain regarding the origin, age, and depositional history of proximal deposits. Further examination of the proximal deposits will lead to a better understanding of the potential hazards that occur during the interaction of snow and ice with hot volcaniclastic debris and that may be encountered during future eruptions of Mount Churchill.

\section{Sample Collection}

A complete assessment of the depositional history and environments of the proximal deposits of White River ash is dependent on qualitative analyses of existing tephra deposits. This is a sizable task because the proximal deposits occur discontinuously for at least $30 \mathrm{~km}$ west of the source volcano (along the north and south margins of Klutlan Glacier), and along Russell Glacier. 
The proximal deposits examined in this study were chosen based on their geographic locations with the aim of discerning regional differences or similarities. Sampling posed a few challenges to reduce the problem of collapse and sample undisturbed layers. Each terrace was initially examined by observing the level at which distinct laminations were present at the base of the deposit. In areas where surficial pumice (displaced by downslope creep of upper units) was present, the surface material was removed by shovel to expose the undisturbed horizontal beds underneath. Each deposit was studied by cutting obliquely across the angle-of-repose slope with a shovel, exposing undisturbed beds in linked segments up to $1 \mathrm{~m}$ thick (cf. Donaldson et al. 1996). Detailed observations and measurements were made for subsequent textural analysis as they were systematically exposed. Samples were taken from various levels in the terrace deposits to side-step permafrost (which occurs as close as $0.5 \mathrm{~m}$ below the surface) and to analyze variations in texture and depositional process throughout accumulation of terrace facies.

\section{Methodology}

The textural features examined in this study include sphericity, sorting, roundness, and size of grains. Through comparison with known sediment characteristics, processes, and depositional environments, inferences are made about these textural features and the transport processes (e.g. energy regime, distance and mode of transport) to further elucidate depositional and resedimentation history of the proximal deposits of White River ash. The sediment 
characteristics described in this study are the result of processes that occurred either prior to deposition (e.g. transport) or after deposition occurred (resedimentation).

\section{Sphericity}

Sphericity of selected samples was determined by plotting the axial ratios of the largest tephra grains on Zingg diagrams (Boggs 2001). The a-axis was measured as the longest dimension of each grain, the b-axis was measured perpendicular to the a-axis, and the c-axis as the shortest dimension of each grain. Based on the $a-b-c$ ratios, the form was determined to be oblate (disc), equant (spherical), bladed, or prolate (roller; Boggs 2001). Since volcanic lapilli are typically angular at the time of deposition, primary airfall deposits tend to plot in the oblate or bladed shape fields, depending on the degree of reworking (Sneed and Folk 1958; Boggs 2001). Clasts that were reworked exhibited a wider range of shapes depending on the transport mechanism and the degree of reworking (Sneed and Folk 1958; Boggs 2001). Most samples that had been fluvially reworked (as evidenced by accompanying sedimentological features) had clasts that plotted in the equant shape field.

To ensure accuracy in measurements, samples with a predominance of lapilli or larger-sized grains were selected so they could be easily measured using a digital caliper. Lapilli-sized fragments were abundant along the lateral margins and the termini of the Klutlan and Russell Glaciers, which are sourced in the saddle between Mount Churchill and Mount Bona, as well as in the Mount Natazhat region (Figure 27). 


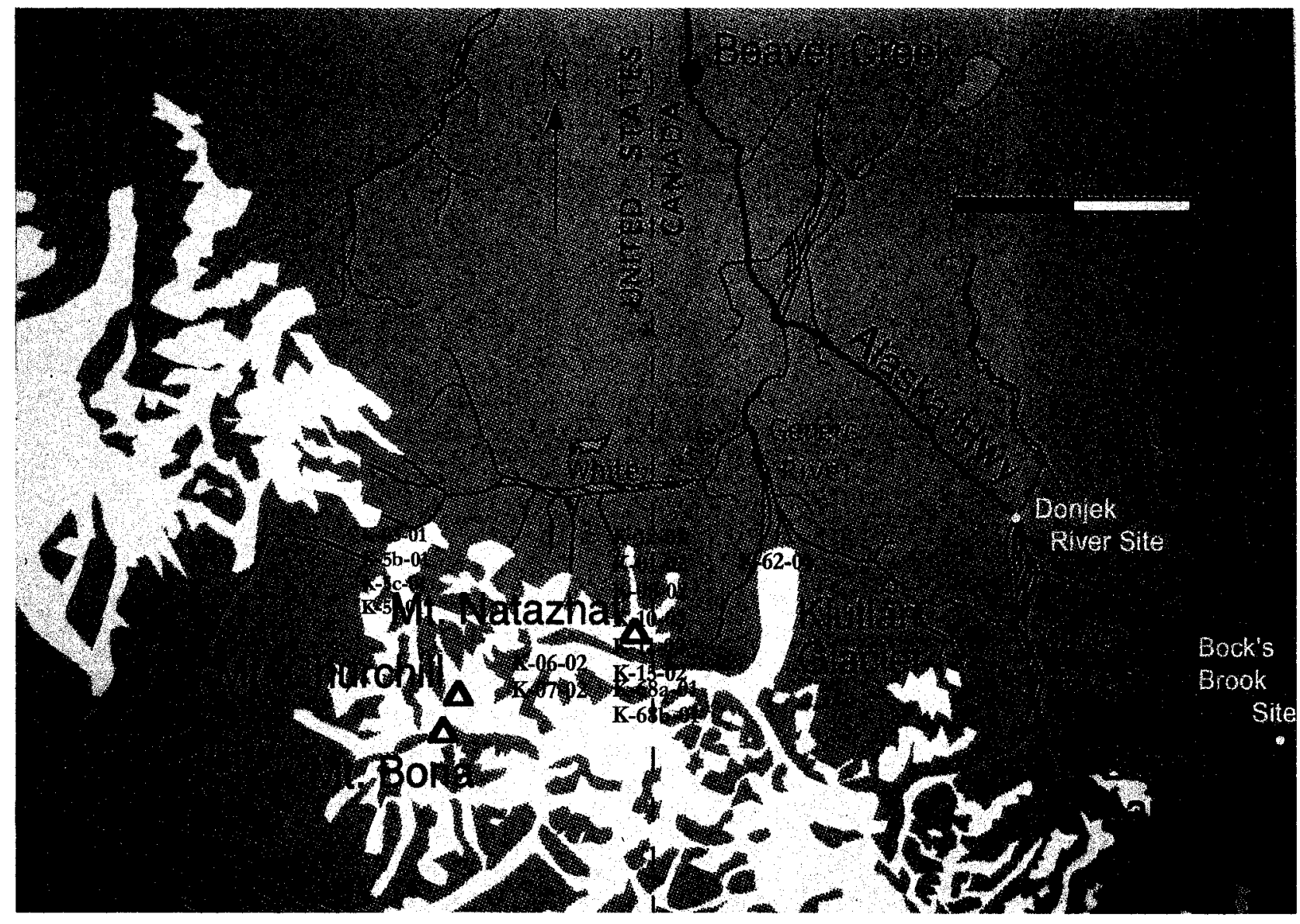

Figure 27: Location of samples selected for textural analysis. Samples collected for analysis of sphericity are marked in blue, while samples collected for size or sorting analysis are marked in green or red, respectively. If a sample was used for more than one type of analysis, it is marked in purple. Distal deposits of ash are marked in yellow. After Donaldson et al. (1996). 
Two samples were collected from the terminus of Russell Glacier, nearly $25 \mathrm{~km}$ from Mount Churchill, the volcanic source. In this area, ash and lapilli appeared as discontinuous exposures up to 1 meter in thickness that were approximately 100 to 200 meters above the terminal moraine deposits. Both samples, K-3-01 (Figure 28) and K-5f-01 (Figure 29) were within walking distance of each other along the east margin of the glacier. The shape distribution from both samples indicates a fairly high degree of fluvial reworking. It is possible that these clasts were transported from the volcanic source to the terminus of the Russell Glacier by hyperconcentrated flood flows. The predominance of equant clasts suggests that streams reworked these deposits before they were deposited in their present locations. While it has been suggested for some time that the melting of snow and ice played a large part in the deposition of ash and lapilli on Klutlan Glacier (Donaldson et al. 1996), the degree of reworking in these samples indicates, for the first time, that similar reworking processes were in play along Russell Glacier.

Mount Natazhat, to the east of Russell Glacier and approximately $11 \mathrm{~km}$ (7 miles) west of the Alaska/ Yukon border, also contained abundant exposures of ash and lapilli at its terminus (Figure 27). In this region fine to coarse-grained ash and lapilli were present. Most exposures were about 1-1.5 metres thick and occurred as terraces or mounds. In some places, the glacier reworked the lapilli/ash, as evidenced by morainal deposits. However, the vast majority of samples from this region (K-01-02, K-08-02, K-10-02, K-11-02, and K-15-02), collected within 5-7 kilometres of one another, represent primary airfall deposits (Figures 30-34). Distinctive 
K-03-01

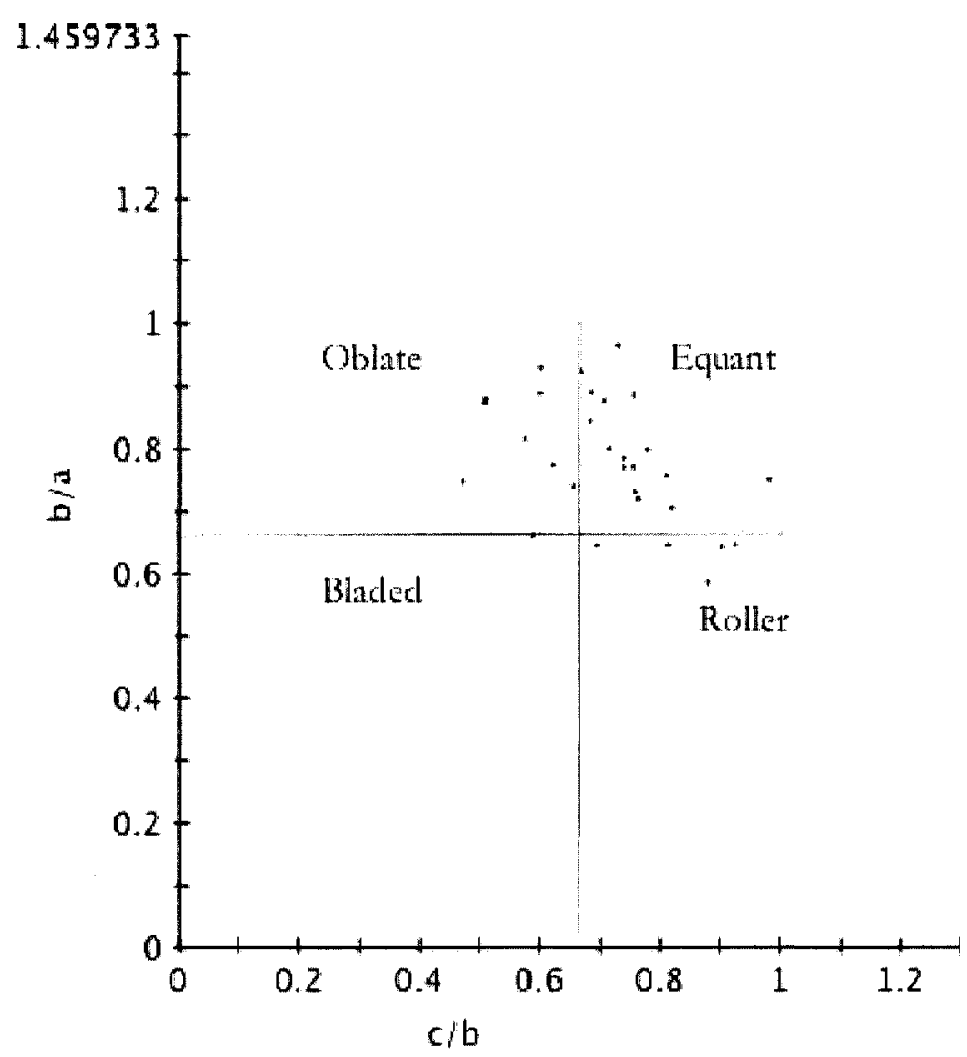

Figure 28: Zingg diagram indicating sphericity of sample K-03-01, located along Russell Glacier. The shape of clasts (oblate, equant, bladed, or roller) is determined by their position on this diagram. Most clasts in sample K-03-01 are equant or oblate. 
K-5f-01

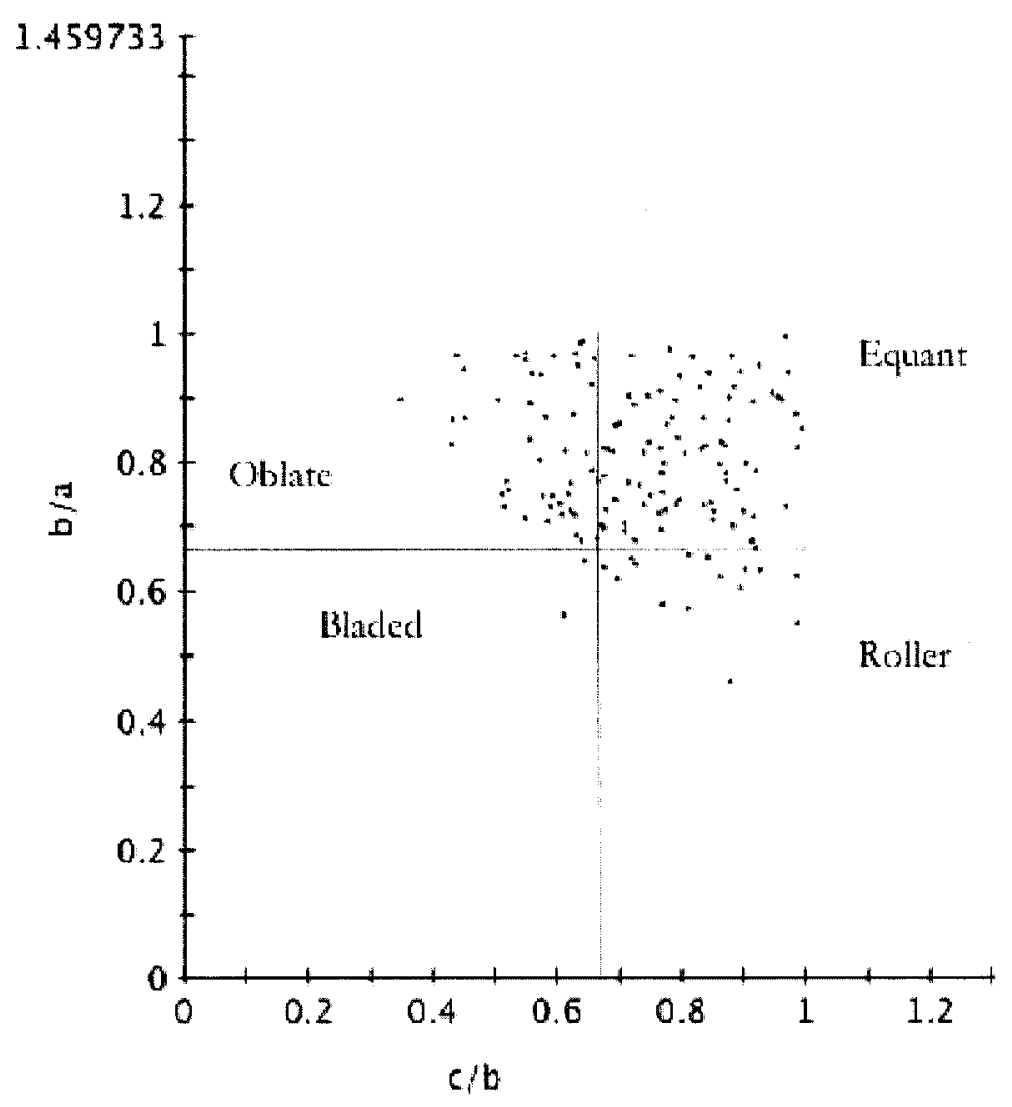

Figure 29: Zingg diagram indicating sphericity of sample K-5f-01, located along Russell Glacier. The shape of clasts (oblate, equant, bladed, or roller) is determined by their position on this diagram. Most clasts in sample K-5f-01 are equant or oblate. 


\section{K-01-02}

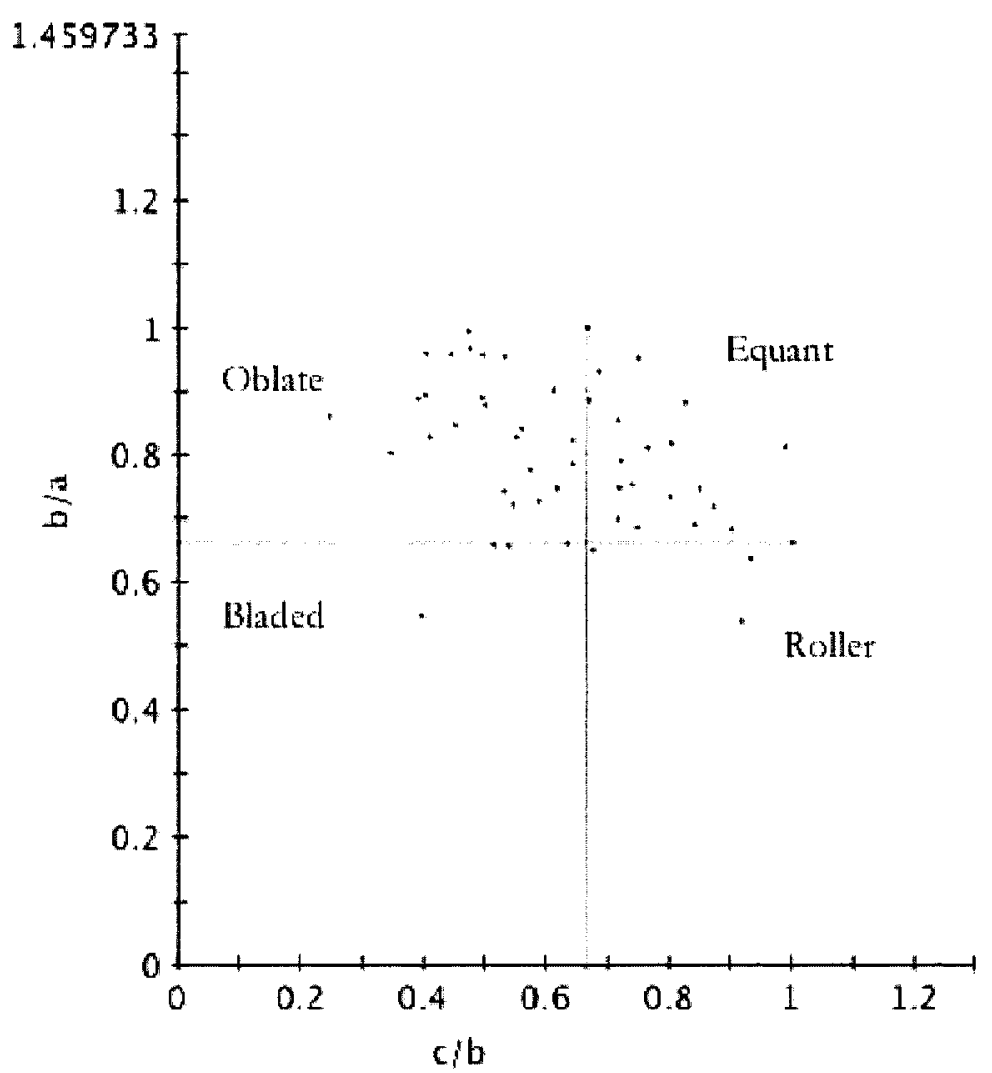

Figure 30: Zingg diagram indicating sphericity of sample K-01-02, located along Natazhat Glacier. The shape of clasts (oblate, equant, bladed, or roller) is determined by their position on this diagram. Most clasts in sample K-0102 are equant or oblate. 
K-08-02

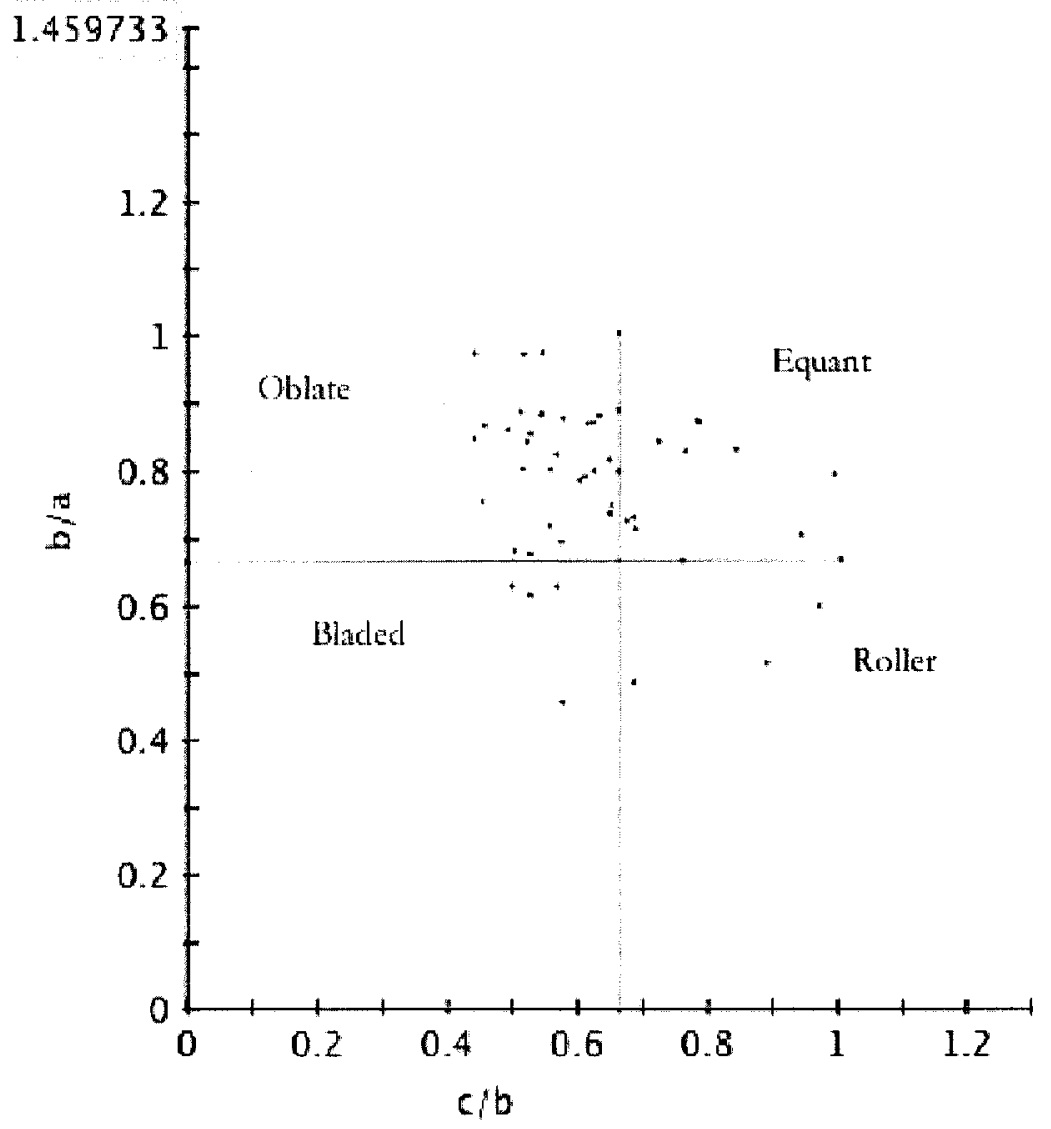

Figure 31: Zingg diagram indicating sphericity of sample K-08-02, located along Natazhat Glacier. The shape of clasts (oblate, equant, bladed, or roller) is determined by their position on this diagram. Most clasts in K-08-02 are oblate. 
K-10-02

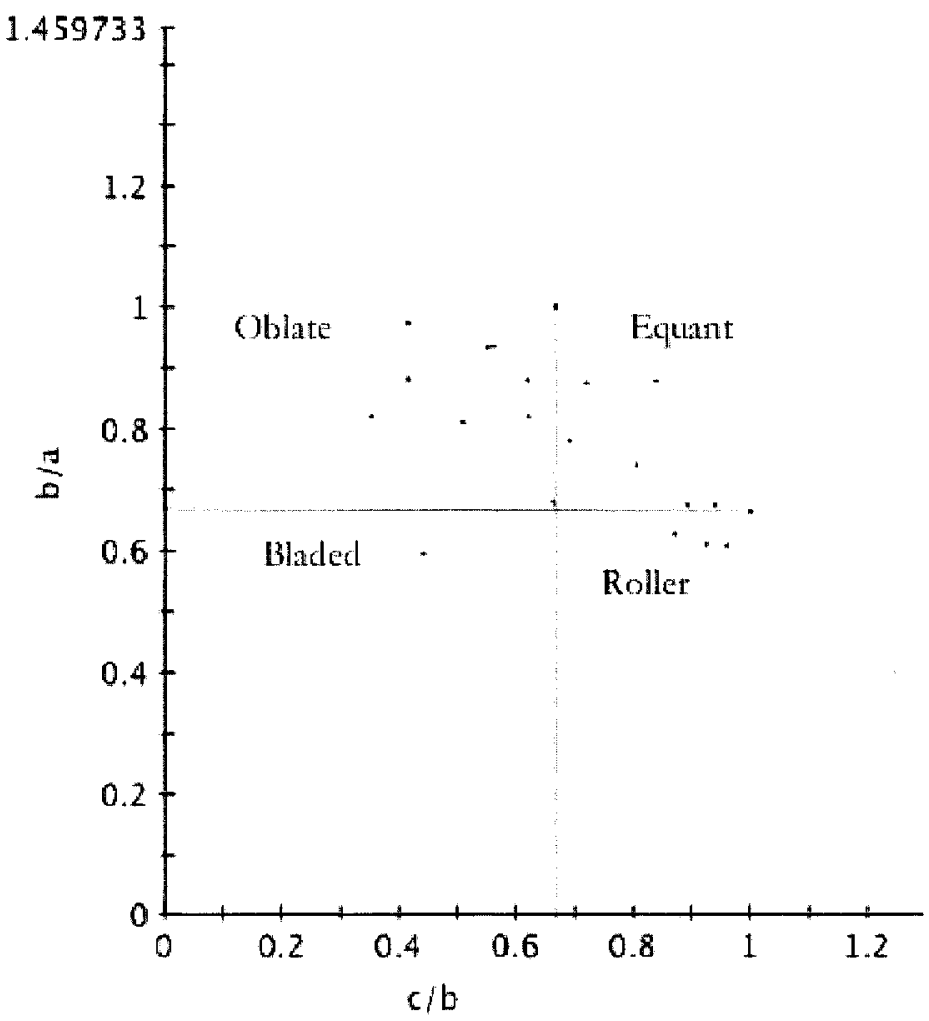

Figure 32: Zingg diagram indicating sphericity of sample K-10-02, located along Natazhat Glacier. The shape of clasts (oblate, equant, bladed, or roller) is determined by their position on this diagram. Most clasts plot in sample K-10-02 are equant or oblate. 
K-11-02

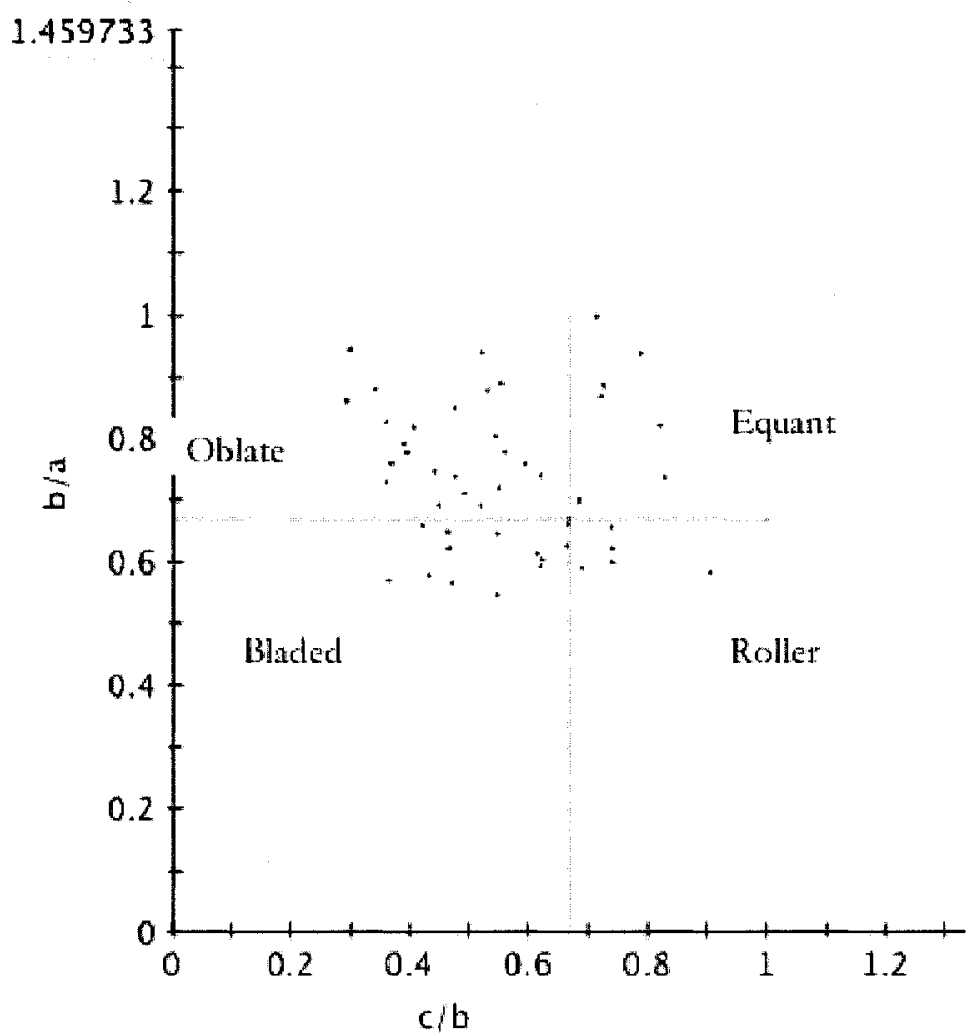

Figure 33: Zingg diagram indicating sphericity of sample K-11-02, located along Natazhat Glacier. The shape of clasts (oblate, equant, bladed, or roller) is determined by their position on this diagram. Most clasts in sample K-11-02 are oblate. 


\section{K-15-02}

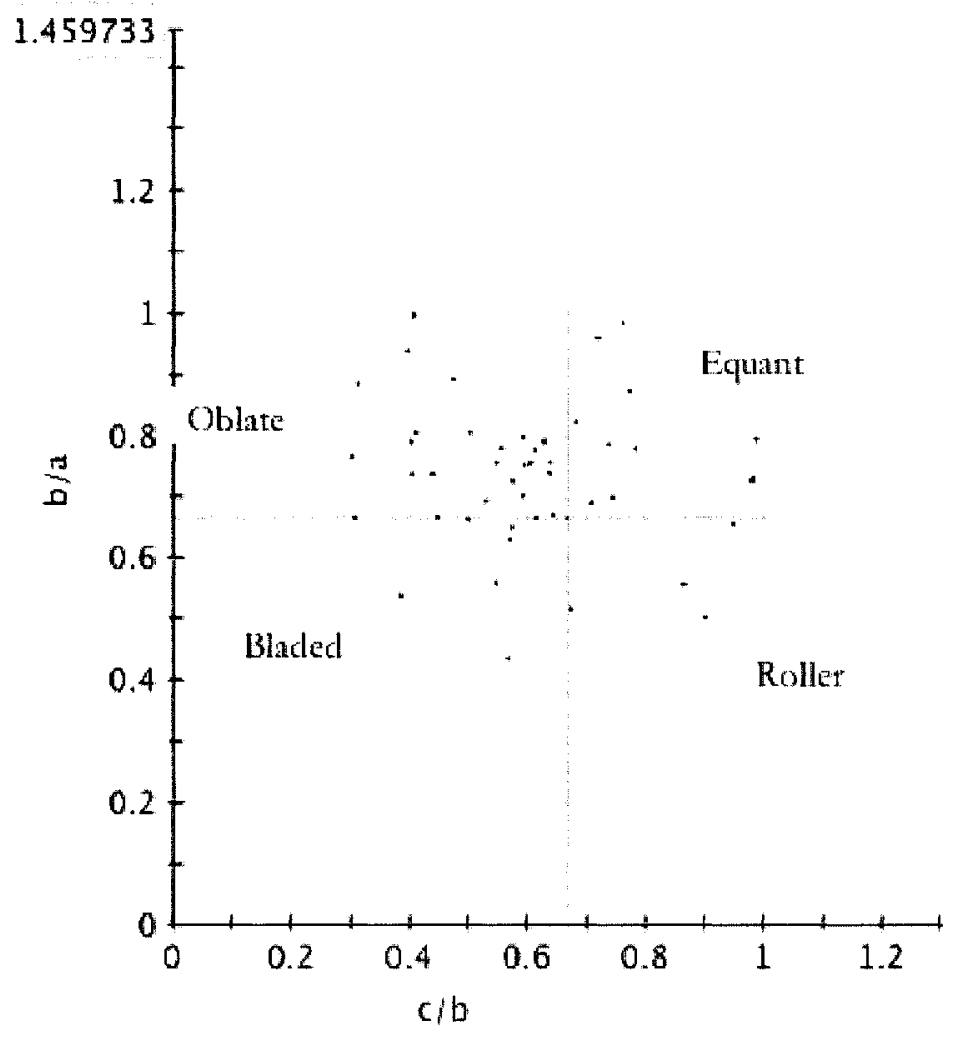

Figure 34: Zingg diagram indicating sphericity of sample K-15-02, located along Natazhat Glacier. The shape of clasts (oblate, equant, bladed, or roller) is determined by their position on this diagram. Most clasts in sample K-15-02 are oblate. 
features, suggestive of an airfall origin, included horizontal laminations and normal grading. Variations amongst grain size data (e.g. a large percentage of equant clasts in samples like K-0102) were compatible with sedimentological features from the field that were indicative of reworking. It is likely that most of the samples from this region represent airfall because the Natazhat glacier is not directly sourced from the Bona-Churchill col.

Klutlan Glacier, sourced in the saddle between Bona and Churchill, contains locally resedimented terraces of ash and lapilli along its lateral margins, as well as an apron of volcaniclastic debris at its terminus (Figure 27). Samples collected from the margins of the glacier, K-06-02 (Figure 35) and K-71-01 (Figure 36) contain predominantly oblate or equantshaped clasts. It is entirely plausible that this ash and lapilli was deposited when hot volcanic material mobilized snow, ice, and volcanic debris downglacier, as seen in the Russell Glacier region. The lesser degree of reworking in sample K-06-01 may be due to its proximity to the volcanic source; the increased percentage of equant clasts in sample K-71-01 may reflect reworking by multiple flood pulses. A sample collected from the terminus of Klutlan Glacier (K-62-01), in the apron of volcaniclastic debris, contains mostly equant clasts (Figure 37). Due to its location and high level of reworking, this sample indicates probable reworking of previously resedimented material. 


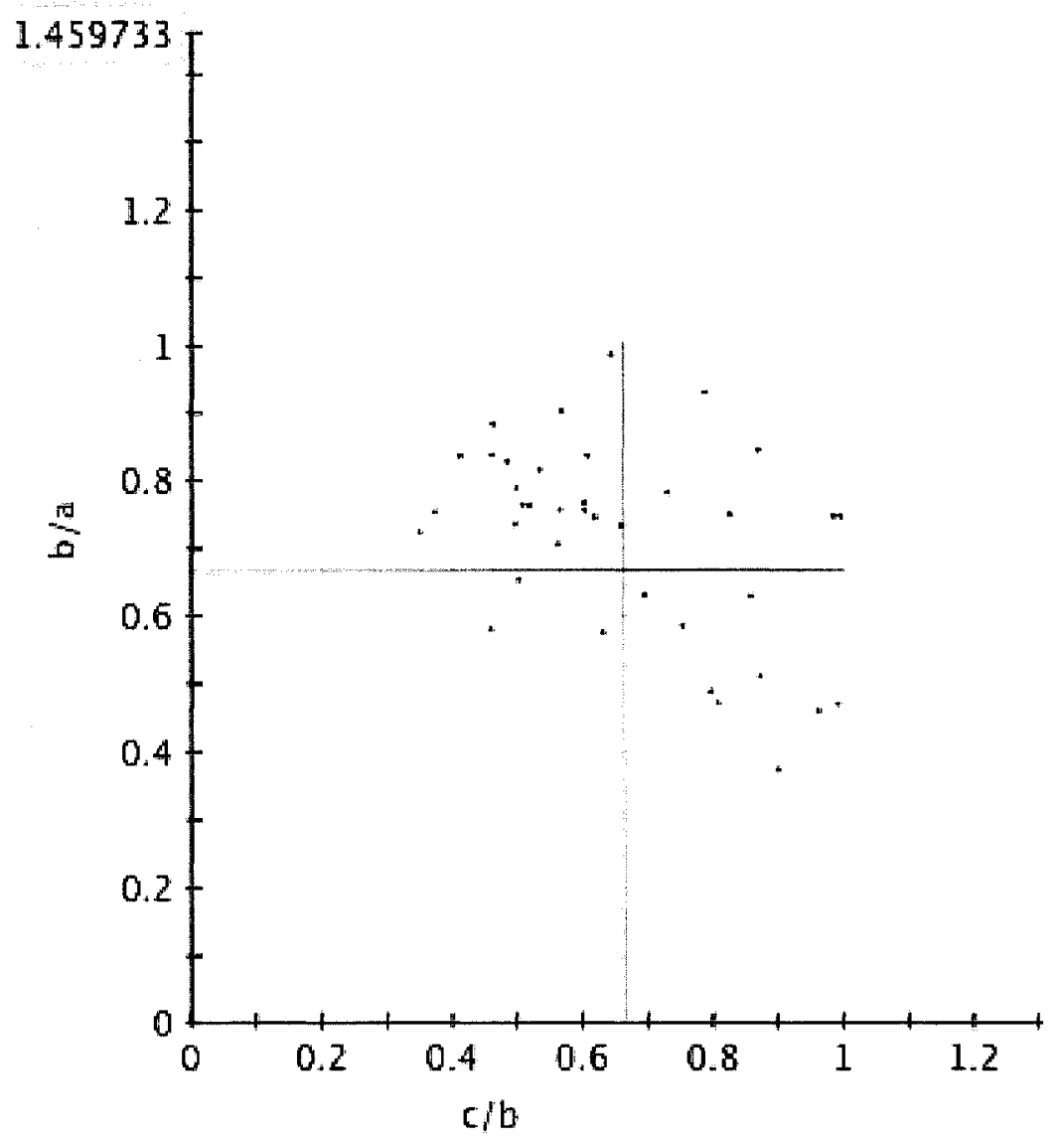

Figure 35: Zingg diagram indicating sphericity of sample K-06-02, located along Klutlan Glacier. The shape of clasts (oblate, equant, bladed, or roller) is determined by their position on this diagram. Most clasts in sample K-06-02 are oblate. 
K-71-01

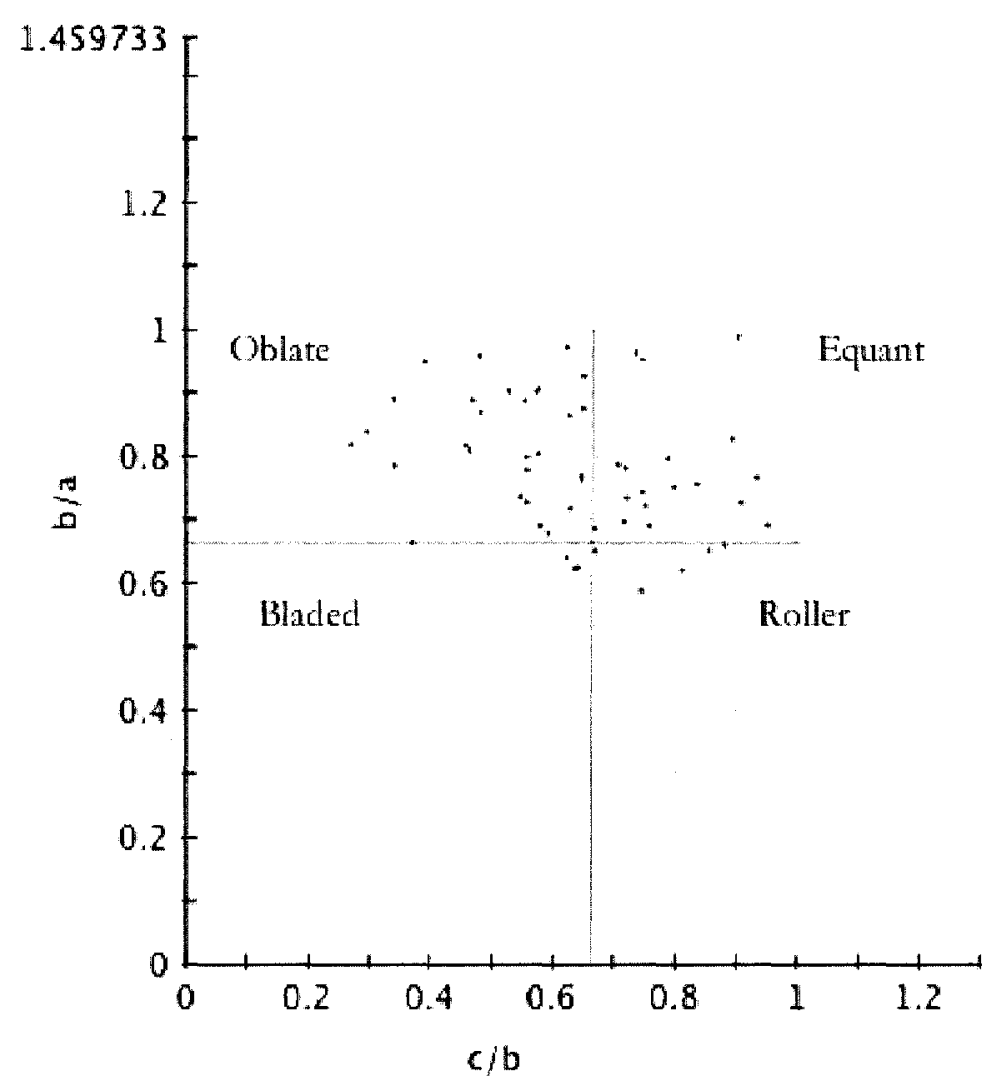

Figure 36: Zingg diagram indicating sphericity of sample K-71-01, located along Klutlan Glacier. The shape of clasts (oblate, equant, bladed, or roller) is determined by their position of this diagram. Most clasts in sample K-71-01 are oblate or equant. 
K-62-01

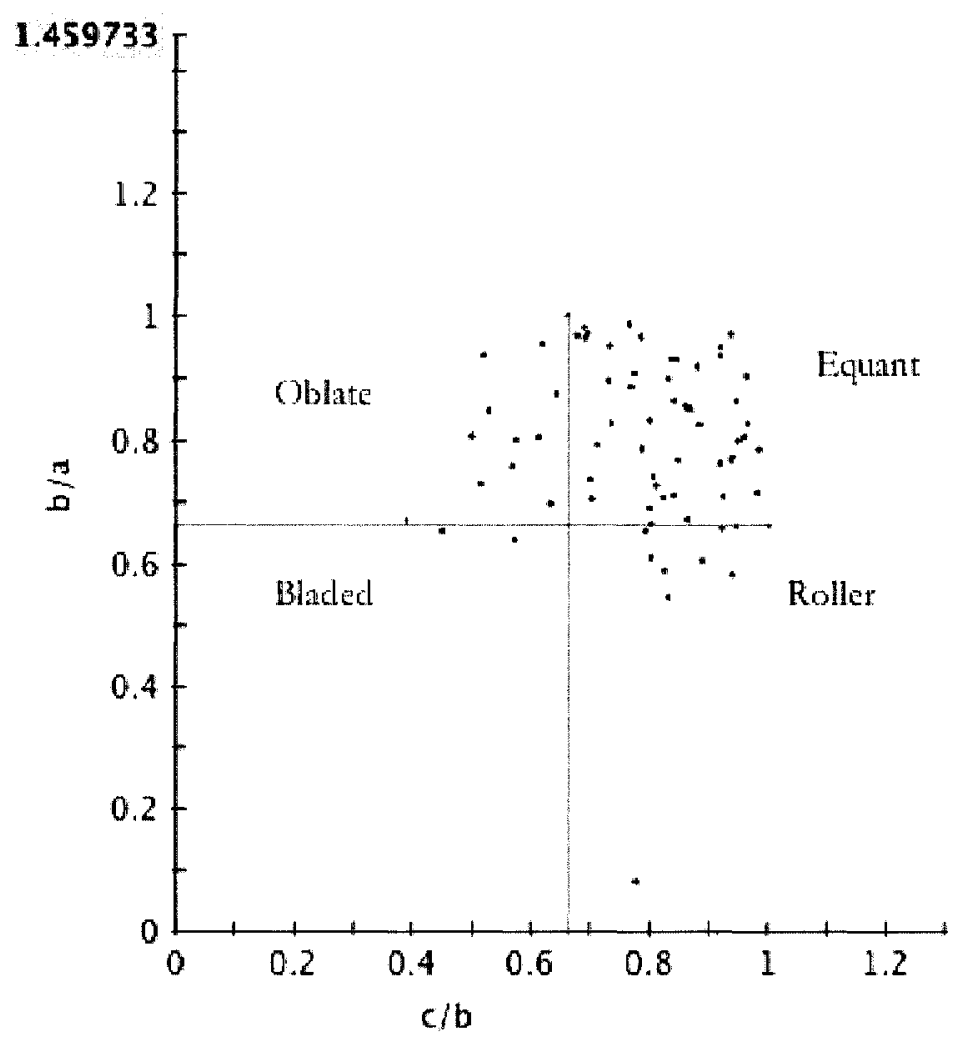

Figure 37: Zingg diagram indicating sphericity of sample K-62-01, located along Klutlan Glacier. The shape of clasts (oblate, equant, bladed, or roller) is determined by their position on this diagram. Most clasts in sample K-62-01 plot are equant. 


\section{Grain Size and Sorting}

Fine-grained samples were hand-sieved through phi-unit mesh sizes of 4.699, 2, 1, 0.5, 0.3, 0.175 , and $0.147 \mathrm{~mm}$, then weight percentages were determined. Size classification (bombs, blocks, lapilli, and ash) follows the nomenclature outlined in Figure 46. Samples were collected from the termini of Russell and Natazhat Glaciers, as well as at various points along Klutlan Glacier (Figure 27). In addition, clasts were compared to Powers grain images to determine the degree of angularity or roundness. Grain sizes of several samples are illustrated in Figure 38. Estimations of sorting are based on visual observations in the field; a cumulative weight curve of the samples has also been provided (Figure 39).

Two samples were collected from an exposure of ash approximately $100 \mathrm{~m}$ above morainal deposits of Russell Glacier (K-5b-01 and K-5c-01). The unit was approximately 1 meter in thickness and contained three layers that were very distinctive from one another. The upper layer was $20 \mathrm{~cm}$ thick and contained medium-grained ash with silt interlayers (K-5c-01; Figure 40). The middle layer was $55 \mathrm{~cm}$ thick and composed of sub-rounded, equant lapilli and ash with prominent horizontal laminations and normal grading (K-5b-01). The lower layer was 25 $\mathrm{cm}$ thick and contained well-sorted medium-grained ash that was slumped over a lower layer of peat. A layer of peat and vegetation capped the unit. The grain size, location, and distribution of this deposit (in particular, the rounding of grains in the middle layer) seem to 


\section{Size Distribution of White River Ash Samples}

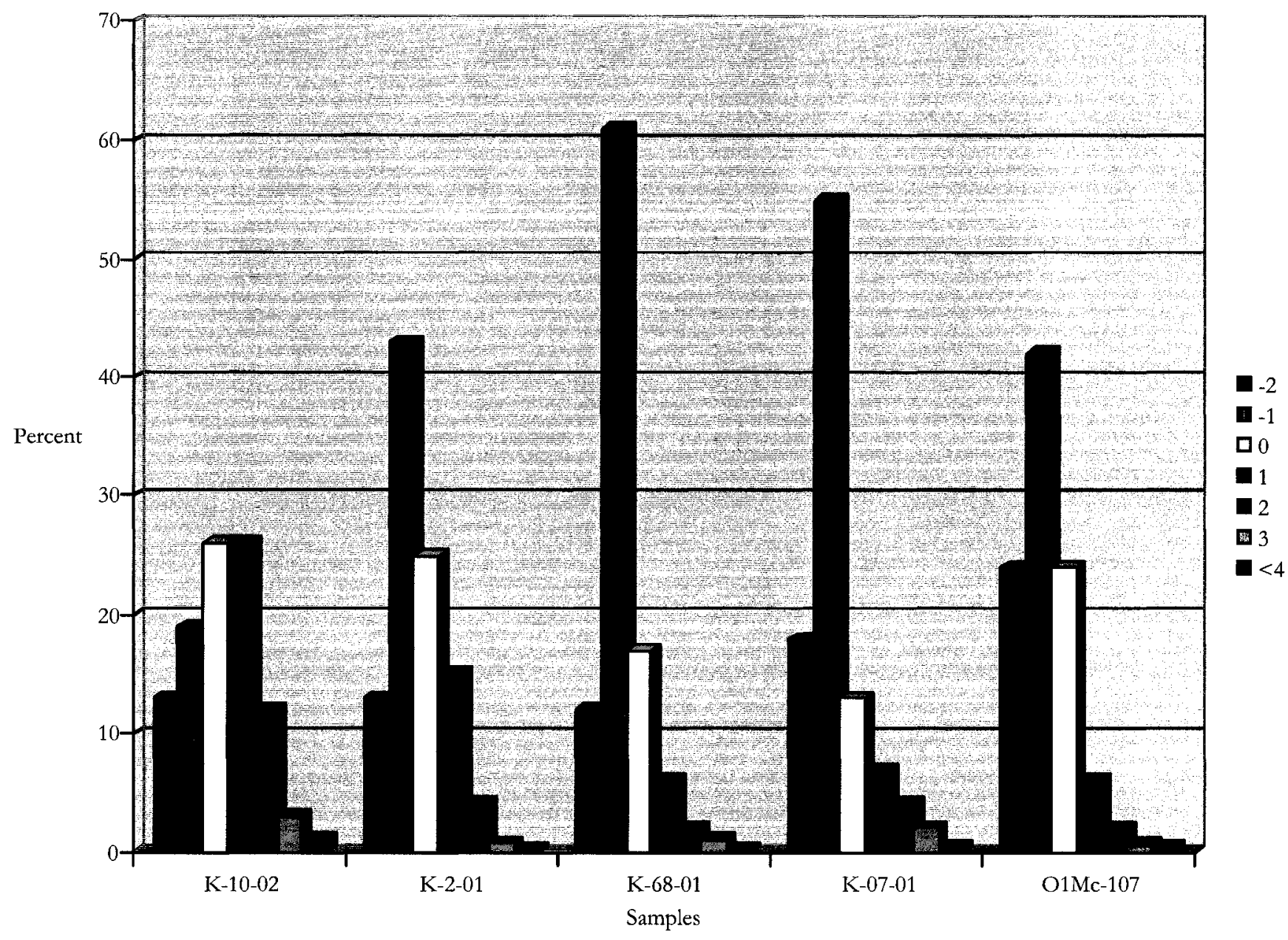

Figure 38: Size distribution of White River ash samples, with each bar representative of the percent weight of each size fraction in the sample. 


\section{Cumulative Weight Curves}

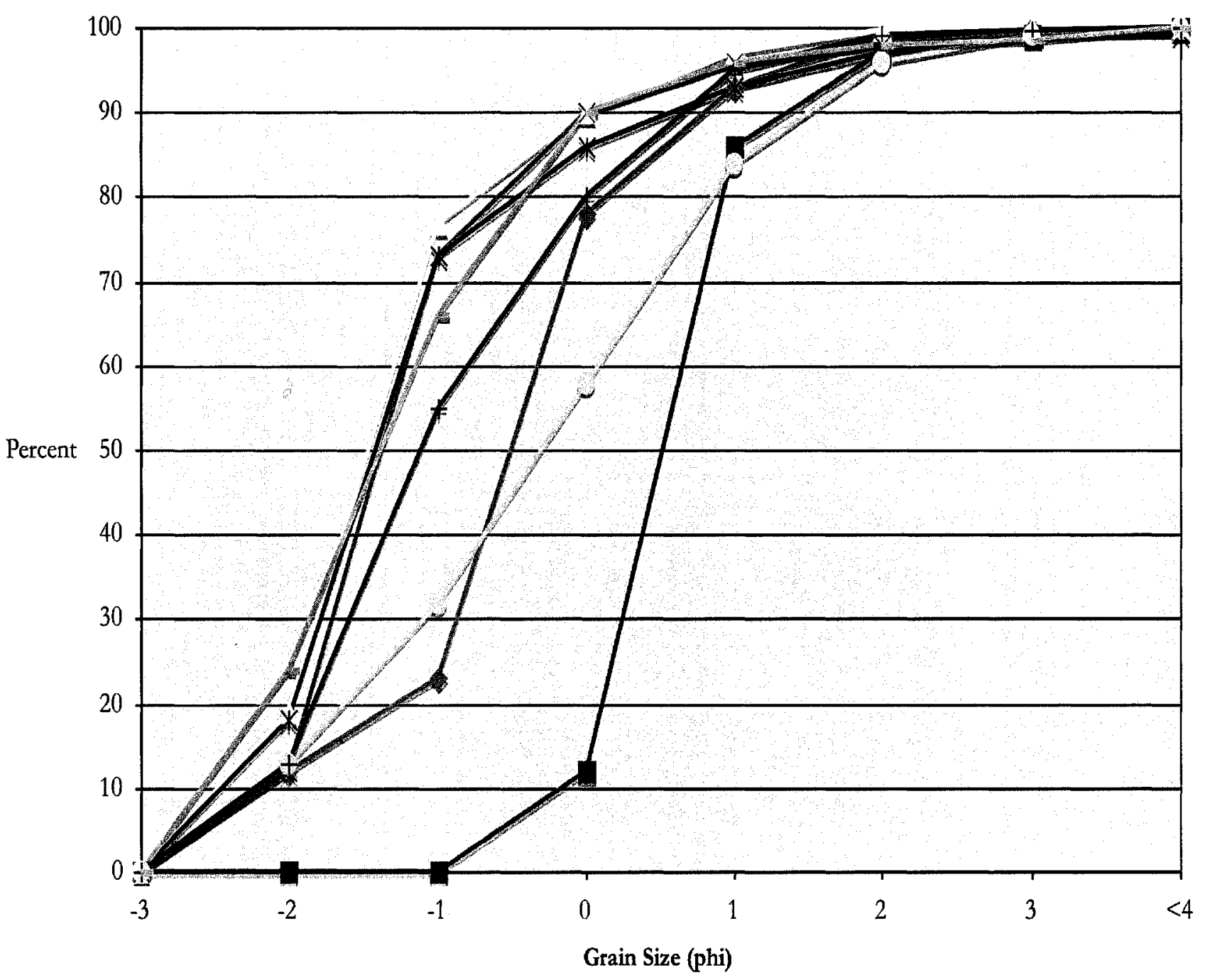

Figure 39: Cumulative weight curve of samples collected. Steep curves in the central part of the diagram indicate good sorting; shallow curves indicate the opposite. 


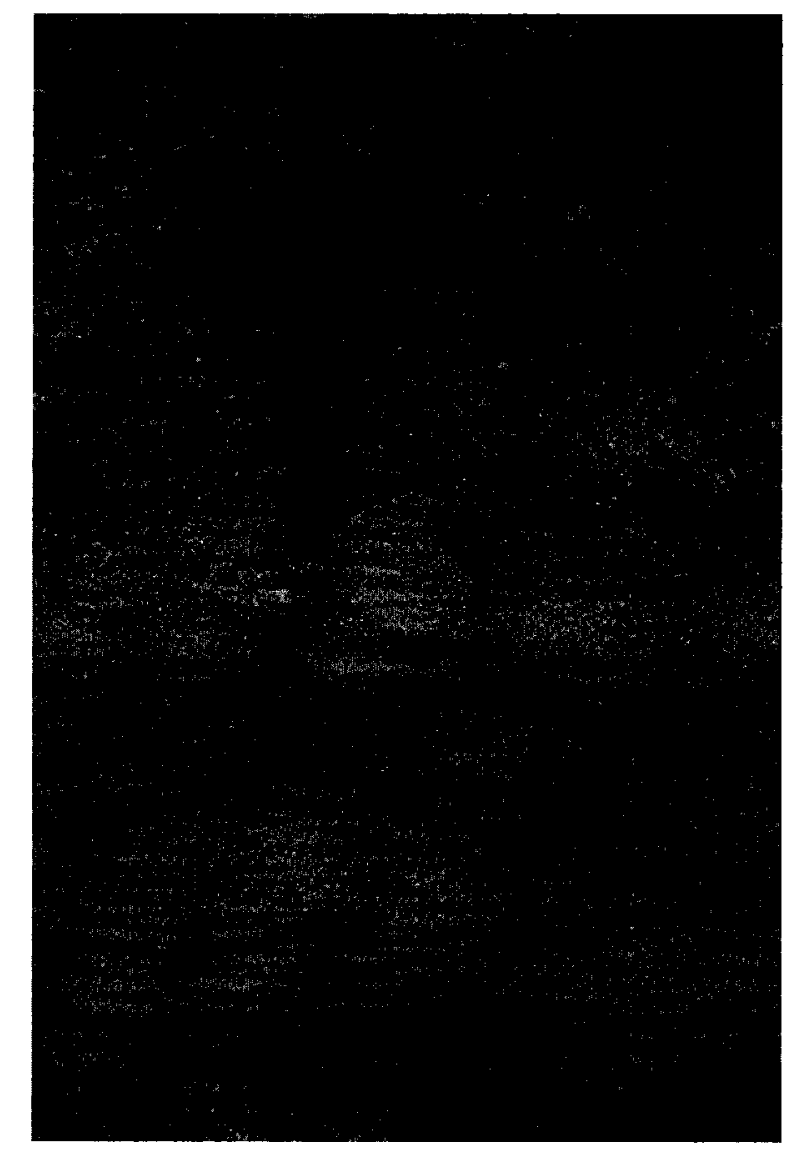

Figure 40: Medium-grained ash with silt interlayers, near Russell Glacier. 
suggest that this deposit was fluvially reworked. The material may have been deposited on an overbank fan, possibly during spring, when flooding may have occurred.

Sample K-68a-01 was collected from the top unit of a 22-meter thick terrace on the south side of Klutlan Glacier. The sample contains a predominance of pristine, white, angular lapilli up to $4 \mathrm{~cm}$ in diameter. Most lapilli are smaller than the maximum-sized clasts, falling in the range of $2-3 \mathrm{~cm}$ in diameter. The unit is well-sorted, normally graded and horizontally laminated (Figure 41). A few lithics are present (3-5\%), which may represent exotics ejected at the time of eruption, or stones from the talus slopes above the terrace. It appears that this material represents original airfall, due to the angularity of the lapilli and the bedding features. This unit may represent a waning pulse of eruptive activity near the end of either eruption of White River ash, or it may represent a younger unidentified eruptive event.

Sample K-68b-01 was discovered in a coulee directly behind the terrace where sample K-68a01 was collected. This sample contained a predominance of sub-rounded to rounded fine to medium-sized lapilli and a lesser amount of coarse to medium-grained ash. The lack of finer ash material, roundness of clasts, sorting, and proximity to a larger terrace deposit suggests that this unit may represent resedimented material that was transported and reworked fluvially. 


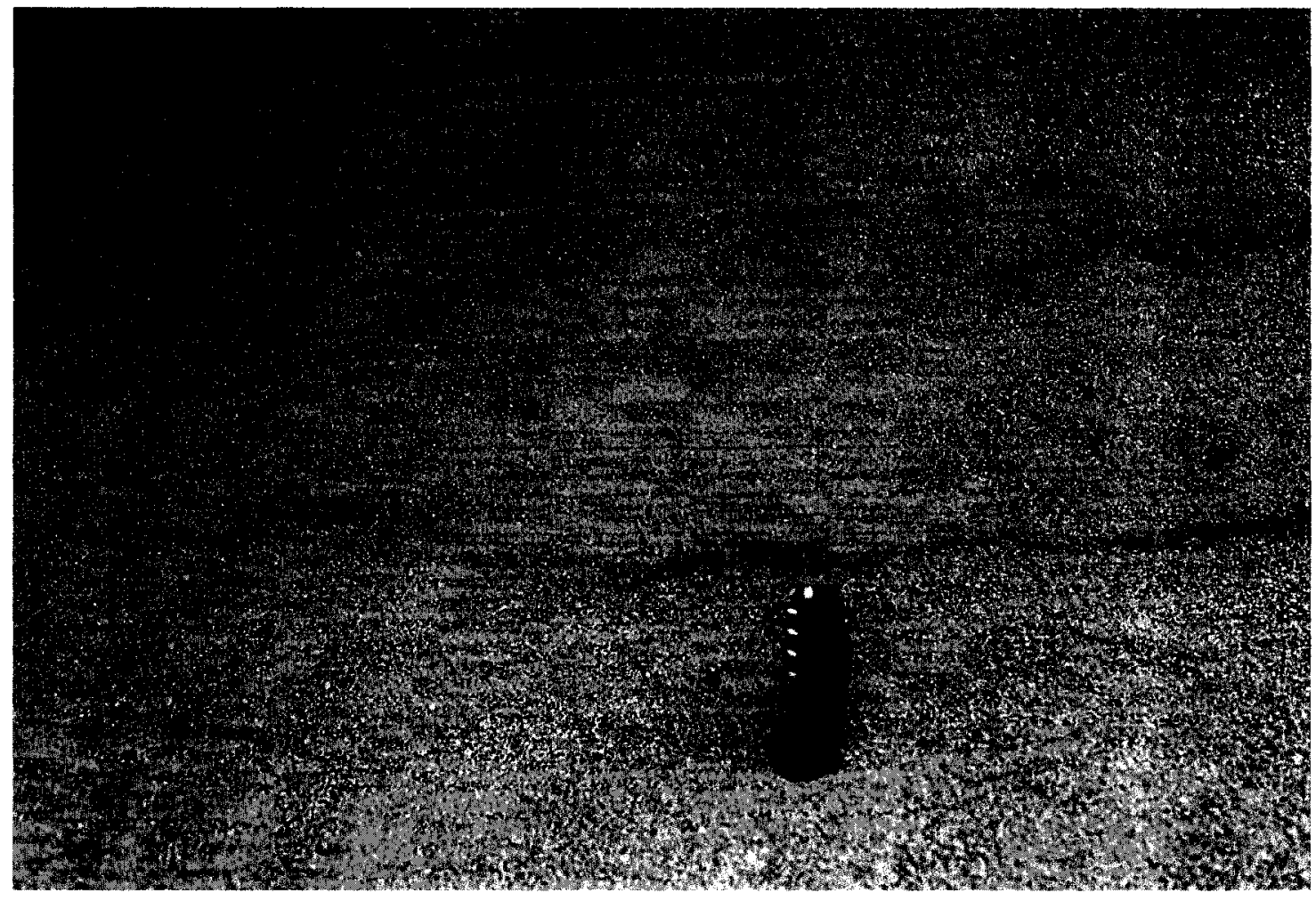

Figure 41: Airfall ash (sample K-68a-01) collected from the top of a 22 metre thick terrace. This ash displays normal grading, horizontal laminations, and is well-sorted. 
A mixture of fine-sized lapilli and coarse-grained ash (Sample K-07-02) was collected in an exposure located along the east margin of Natazhat Glacier. This sample contains pristine sub-angular bladed lapilli within a smaller proportion of coarse-grained ash. The unit is moderately well-sorted and contains approximately $10 \%$ lithics. Although the unit does not display horizontal laminations or graded bedding, the grain size and shape of this deposit indicates that it likely is a primary airfall unit.

A poorly sorted mixture of lapilli and ash (Sample K-10-02) was collected from a 3 meter thick terrace adjacent to Natazhat Glacier. The sample contains fine-grained ash as well as pristine, white, sub-rounded to rounded lapilli up to $5 \mathrm{~cm}$ in diameter. The unit contains no apparent bedding, and even though it is not well-sorted, there is no volcaniclastic or lithic detritus incorporated in the deposit. The bimodal distribution of the deposit suggests that the lapilli may have underwent an earlier period of reworking. It is possible that the ash and lapilli may have been mixed together and then transported to this location. If blocks of ice or large volumes of volcaniclastic debris created ponded areas shortly after the eruption occurred, the subsequent breakage of the natural dams may have resulted in large volumes of volcaniclastic sediment and debris being mixed together and deposited at the terminus of the glacier.

Sample K-12-02 was collected near the terminus of Natazhat Glacier and consists primarily of fine- to coarse-sized lapilli within coarse- to medium-grained horizontally laminated ash. Smaller lapilli are more angular and tend to be oblate or bladed, whereas larger grains are more 
rounded and spherical. The size and shape of the grains indicates reworking; it is possible that the bimodal distribution resulted from primary airfall (fine-sized lapilli) and reworked deposits (medium-- to coarse-sized lapilli) that were locally resedimented by water and mixed together.

G. McGimsey collected the final sample, 01Mc-107, along a tributary east of Russell Glacier. The sample contains angular to sub-angular bladed fine to medium-sized lapilli with a moderate proportion of coarse-grained ash. The unit is $110 \mathrm{~cm}$ thick and is moderately wellsorted. Based on its location, grain size, and shape, it is likely it represents primary airfall.

\section{Discussion}

Proximal deposits of White River ash differ substantially from distal deposits, and even from one other in close geographic proximity. This implies that a number of transport processes were at play during and subsequent to the eruptive events. Various deposits, including primary airfall and fluvial reworked deposits, exist along the margins and at the termini of Klutlan, Natazhat, and Russell Glaciers. It is expected that proximal deposits are also present along the margins of several unnamed glaciers and tributaries in the Mount Churchill region.

Several textural features distinguish primary airfall deposits: angular to sub-angular clasts, bladed to oblate shapes, coarse to medium-sized lapilli (if relatively near the vent), normal grading, unweathered profiles, and moderate sorting. Reworked airfall deposits retain many of the same features that are slightly modified: sub-angular to sub-rounded clasts, oblate shapes, 
coarse to medium-sized lapilli (if relatively near the vent), and improved sorting. Depending on the nature of reworking, some deposits may contain normal grading or horizontal laminations. A bimodal distribution occurs when resedimented ash is mixed with other pyroclastic material. Reworked airfall is typically less pristine than primary airfall, and may be tinted brown or beige due to the presence of silt, clay, or organic staining.

Fluvially reworked deposits are texturally distinct from primary and reworked airfall and display the following characteristics: rounded clasts, equant to oblate shapes, better sorting, and in some cases, sedimentary structures indicative of water deposition. Most reworked deposits are composed exclusively of volcaniclastics, with minimal intermixing of silt, clay, or lithics. Deposits may be inversely or normally graded. In addition, relatively thick deposits and large-sized clasts (up to $14 \mathrm{~cm}$ in diameter) may occur up to $80 \mathrm{~km}$ away from the vent; this is a function of 1) the amount of tephra being redistributed and 2) the low density of pumice, which causes larger tephra clasts to stay in suspension longer (Manville et al. 1998). A number of factors (e.g.) variations in stream velocity, the long-term availability of water as a transporting medium, the interaction of snow and ice with hot tephra, the timing of eruptive events, variations in density of pumiceous material, and the volume of volcaniclastic material are important considerations in assessing the transport mechanisms and depositional origin of the reworked deposits. 
It has been suggested that reworked deposits of ash may have been created in response to the movement of large volumes of water produced by the melting of snow and ice upon contact with hot volcanic debris (Donaldson et al. 1996). This hypothesis is in good agreement with the textural features observed in the fluvially reworked deposits. It is possible that large volumes of water may, in some places, have been ponded by one or more ice dams, resulting in temporary lakes. However, the wide range of textural features observed in this study (primary airfall, reworked airfall, and fluvially reworked lapilli/ ash) are consistent with a range of local transport processes and depositional environments within the areas studied. 


\section{Chapter 4: Facies Analysis of Proximal Deposits}

\section{Introduction}

Although volcaniclastic rocks provide substantial insight into sedimentary processes and stratigraphic relationships, their study, until fairly recently, has focused primarily on eruptive processes and the petrogenesis of volcanic rocks (Fisher and Schmincke 1984; Cas and Wright 1987; Smith 1991a; Kataoka and Nakajo 2002). In recent years, opportunities to carry out research on eruptions first-hand such as Paricutin (1943-52; Segerstrom 1950, 1966), Mount St. Helens (1980; Schuster 1981; Meyer et al. 1982; Collins et al. 1983; Lehre et al. 1983; Pierson. and Scott 1985; Scott 1988; Major et al. 2000), Nevado del Ruiz (1985; Naranjo et al. 1986), and Pinatubo (1991; Major et al. 1996; Pierson et al. 1992, 1996; Scott et al. 1996; Torres et al. 1996; Umbal and Rodolfo 1996; Montgomery et al. 1999) have resulted in detailed studies of long term volcanic hazards and eruption-induced sedimentation. These studies have been applied to ancient volcanic sequences, providing information about source volcanoes, depositional environments, transport mechanisms, sedimentary processes, and environmental response (Fisher and Schmincke 1984; e.g. Taupo $1.8 \mathrm{ka}$, Segschneider et al. 2002). Such studies have become particularly important in hazard assessment when large volumes of volcaniclastic sediment initiate severe (and possibly long-term) volcanic hazards (White et al. 1997; Kataoka and Nakajo 2002). In many of these cases, primary deposition of detritus is followed by remobilization, which often results in damage greater than that caused by the original eruption (e.g. Pinatubo; Torres et al. 1996; Segschneider et al. 2002). 
In the past few decades, this new focus, in combination with traditional volcanological studies, has resulted in a diverse approach to the study of volcaniclastic rocks and their associations in a variety of sedimentary settings (Cas and Wright 1987; Smith 1991b). Increasingly, studies are focusing on eruption-induced sedimentation in regions where snow and ice play a role (Major and Newhall 1989; Pierson and Janda 1994; Pierson 1995; Mount St. Helens: Tagborn and Lettenmaier 1982; Waitt et al. 1983; Waitt 1989; Nevado del Ruiz: Pierson et al. 1990; Thouret 1990; Redoubt: Trabant et al. 1994; Waitt et al. 1994; Ruapehu: Cronin et al. 1996). Eruptions at snow-clad volcanoes can cause syn-eruptive floods and lahars when hot volcaniclastic debris melts summit glaciers and snowcaps, or unusual mass flows termed "mixed avalanches" or "snow slurry lahars" (Cronin et al. 1996). Furthermore, they are host to distinctive transport processes and depositional environments, some perhaps not yet discovered.

\section{Purpose of This Study}

Deposition of $25-50 \mathrm{~km}^{3}$ of White River ash (Bostock 1952; Berger 1960) from volcanic eruptions ca. 1887 (north lobe; Lerbekmo et al. 1975) and 1147 years B.P. (east lobe; Clague et al. 1995) resulted in large-scale modifications to the adjacent glacial landscape and environment. The White River deposit is one of the most widely dispersed volcaniclastic units in North America; distal deposits of unconsolidated ash have been found up to $1300 \mathrm{~km}$ from the source (Robinson 2001; Figure 1). 
Proximal deposits of White River ash were created when large volumes of hot volcaniclastic material mixed with snow and ice and cascaded down adjacent valley glaciers. This process resulted in several distinctive depositional features along the lateral margins of valley glaciers, including locally resedimented terrace (Figure 7) and fan deposits (Figure 8). The study of these proximal deposits offers promise for contributing to our understanding of eruptioninduced sedimentation and long-term remobilization of volcanic detritus and sediment. This chapter aims to further elucidate depositional environments and transport mechanisms of the White River ash through comparison of general and analogous sedimentological features and facies in locally resedimented terrace and fan deposits.

\section{Geologic and Regional Setting}

The White River ash is the result of two pyroclastic eruptions from Mount Churchill in southcentral Alaska (McGimsey et al. 1990). It is distributed in two lobes, the north and east lobes of ash, which collectively cover over $\sim 540,000 \mathrm{~km}^{2}\left(-336,000 \mathrm{mi}^{2}\right)$ of British Columbia, the Yukon and Northwest Territories, and Alaska (U.S.A.; Robinson 2001; Figure 1). Recent work by Jensen and Froese (2006) has expanded the distribution of the White River deposits, suggesting that the northern and eastern lobes of ash covered approximately $100,000 \mathrm{~km}^{2}$ and $500,000 \mathrm{~km}^{2}$ respectively. Radiocarbon estimates indicate deposition of the north lobe ash $\mathrm{ca}$. 1887 years B.P. (Lerbekmo et al. 1975); the much larger east lobe ash is significantly younger in age (1147 years B.P.; Clague et al. 1995). Recent work by Jensen and Froese (2006) also suggests that the north lobe was deposited between 150-500 AD (based on dating of 
floodplain exposures along the Yukon River) and the east lobe at approximately $800 \mathrm{AD}$. The source of both lobes, Mount Churchill, is a glaciated stratovolcano located $25 \mathrm{~km}$ (15 miles) west of the Yukon-Alaska border in Wrangell-St. Elias National Park and Preserve $\left(61^{\circ} 25^{\prime} \mathrm{N}\right.$, 1410’W; McGimsey et al. 1990; Figure 2).

Two lithofacies are distinguished within the White River ash deposit - primary pyroclastic-fall deposits and secondary resedimented volcaniclastics. Primary fall deposits display characteristic features of subaerial fallout, including moderate to good sorting, angular to subrounded fragments and compositionally homogeneous graded beds. The size and thickness of distal deposits depends primarily on the distance from Mount Churchill; most distal deposits appear as $2-5 \mathrm{~cm}$ thick layers of ash in Yukon Territory and Alaska (Figure 4). In contrast, resedimented deposits may be up to 50 meters thick (McGimsey et al. 1990; Richter et al. 1995a) and consist of primary airfall and reworked deposits by gravity, fluvial, and lacustrine processes. These deposits tend to occur as terraces in embayments and valleys, above the erosive reach of glaciers, or in non-glaciated areas (Figure 5). Loose accumulations of tephra, ranging in size from lapilli to pumice blocks up to $50 \mathrm{~cm}$ in diameter, are present along and east of the ridge near the ice-covered top of Mount Churchill (Richter et al. 1995a). This chapter focuses on the composition and stratigraphy of resedimented deposits that occur as discontinuous terraces along the Klutlan, Russell, and Natazhat Glaciers (Figures 7 and 26) and on an apron of volcaniclastic debris located at the terminus of Klutlan Glacier (Figure 8). 


\section{The White River Terraces}

Most terrace deposits occur discontinuously along the 82-km-long Klutlan Glacier (Field 1975;

Driscoll 1980). Little ash is present west or south of Mount Churchill; however, additional terraces occur along Russell Glacier, which flows northward from Mount Churchill.

Terrace deposits tend to increase in thickness up-ice towards Mount Churchill, and are more than 20 meters thick along the lateral margins of Klutlan Glacier, $30 \mathrm{~km}$ east of Mount Churchill (Figures 7 and 26). Tephra fragments within the terrace deposits increase dramatically in size toward Mount Churchill (fragments greater than $20 \mathrm{~cm}$ in diameter occur in sections $20 \mathrm{~km}$ east of Mount Churchill) and display various degrees of angularity (Figure 6). The terrace deposits are impressive features that are composed almost exclusively of reworked volcaniclastic material with steep $\left(>30^{\circ}\right)$ angle-of-repose margins and flat tops. Primary components include sub-angular to sub-rounded clasts of ash, lapilli and sub-angular blocks; additional components include silt, sand, and juvenile accessory lithics. Although airfall is not found within the terraces, layers of primary airfall (up to one meter thick) cap some individual terraces.

Donaldson et al. (1996) completed a detailed facies analysis of a terrace deposit $4 \mathrm{~km}$ east of the Yukon-Alaska border on the north side of Klutlan Glacier. Measured sections of this terrace contained ash, lapilli, and agglomerate, silt and lithic-rich interlayers, and sedimentary structures such as large-scale cross-bedding, normal and inverse graded bedding, linguoid and 
climbing ripples, and channels. In addition, the authors confirmed that the volcaniclastic materials within the terrace contained the same chemical signature as the east and north lobes of White River ash. This discovery, in combination with the terrace's sedimentological features, led the authors to conclude that the terrace was deposited when hot volcaniclastic debris mixed with substantial volumes of snow and ice on the sides of Mount Churchill and within the confines of Klutlan's U-shaped valley.

\section{The White River Fan}

An apron of volcaniclastic sediment occurs adjacent to the rugged St. Elias Mountains, with the fan apex located just beyond the terminus of Klutlan Glacier (N61'36.516', W140 39.522'; Figure 42). This fan has a distinct body of mixed volcaniclastics and sediment unlike most other fans that are differentiated by distinct proportions of clast types (Palmer and Walton 1990). The fan is composed of layers of very coarse-grained sub-rounded clasts of pumice up to $5 \mathrm{~cm}$ in diameter that are inversely graded, and interbeds of lithic-rich layers (Figure 43). Grain size decreases markedly down the fan's length; the fan is thickest near the apex and thins laterally across its 190-metre length. An assessment of composition and sedimentological features suggests that the fan is composed of resedimented detritus reworked by multiple flooding events after it was carried nearly $85 \mathrm{~km}$ by hyperconcentrated flood flows to the terminus of Klutlan Glacier. 


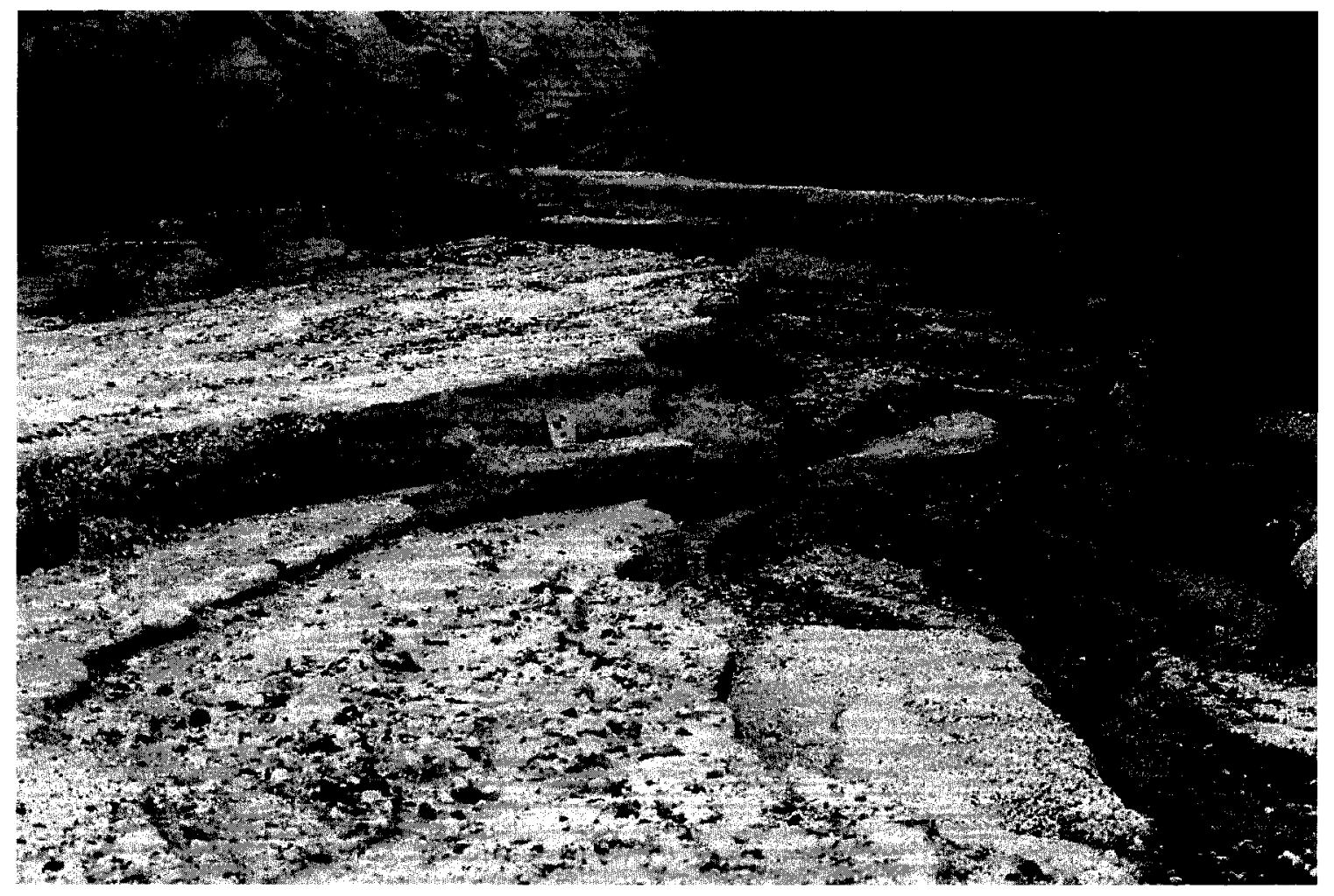

Figure 42: Overview of the fan deposit. The fan is thickest near the apex and thins laterally across its 190-meter length. The grain size of sediment and pyroclastic material within the fan also decreases markedly down the fan's length. 


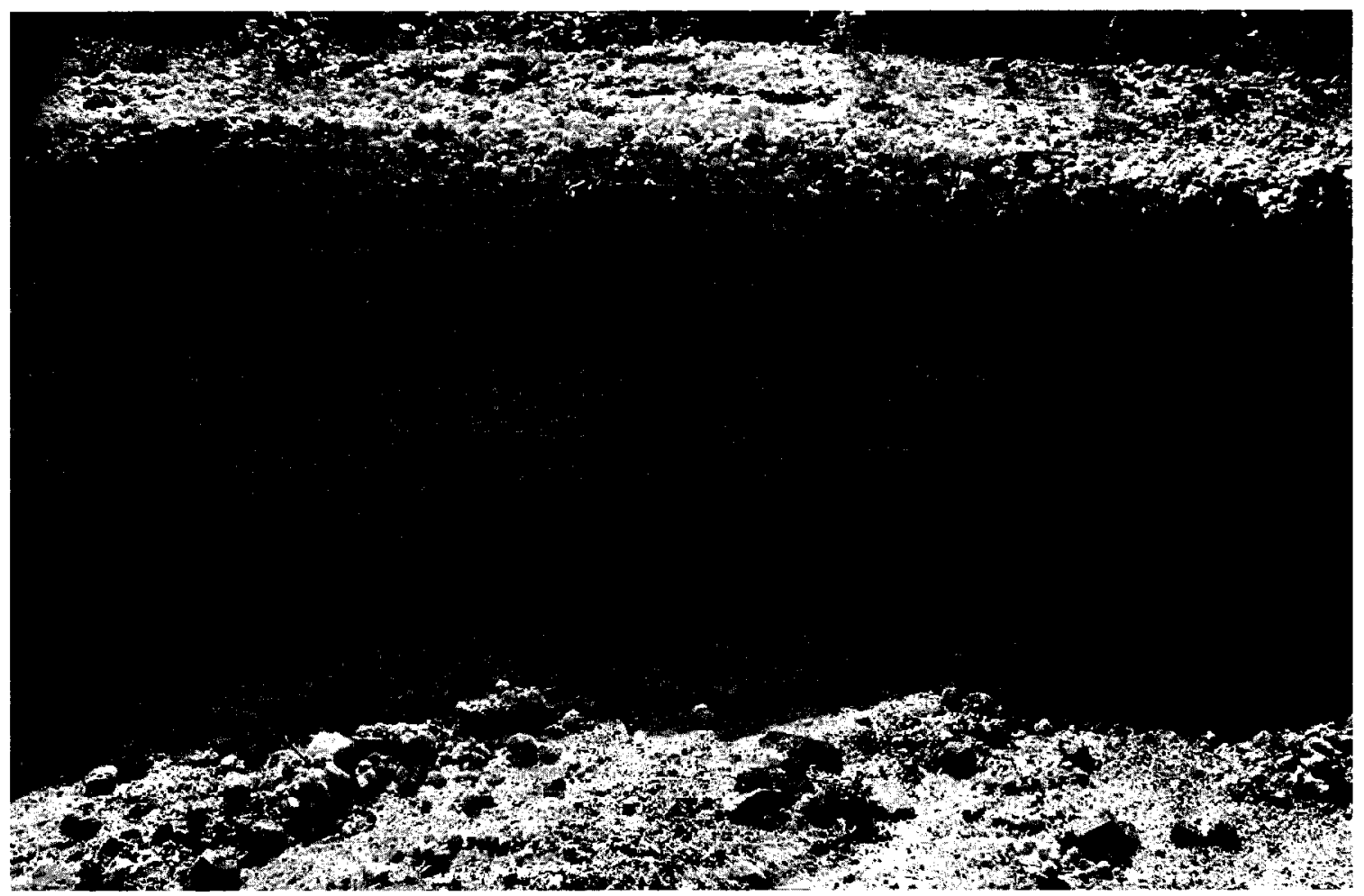

Figure 43: Vertical section through pyroclastic fan deposit, showing alternating layers of very coarse-grained subrounded clasts of pumice up to $5 \mathrm{~cm}$ in diameter that are inversely graded with bands of lithic-rich layers that represent the second-generation resedimentation of pyroclastic material from lahars and hyperconcentrated flows. 


\section{Terminology and Methodology}

This chapter presents data collected on the composition and stratigraphy of locally resedimented deposits of White River ash. One aim of the study is to compare regional similarities and differences between the terrace deposits; the other is to assess the transport mechanisms and depositional environments that were responsible for emplacement of the terrace and fan deposits. Because the only study to date focused on a terrace deposit along the north margin of Klutlan Glacier (Donaldson et al. 1996), locally resedimented features were studied at additional sites along the margins and terminus of Klutlan Glacier for comparative purposes.

A complete facies analysis of two terrace deposits was undertaken to compare the principal sedimentological characteristics as well as the composition and facies of the terrace deposits. To check for regional similarities or differences between the terrace deposits, the locations of terraces for this study were selected east and west of the terrace studied by Donaldson et al. (1986). A strategic decision was made to include terrace deposits on the north and south sides of the glacier, as well as terraces that differed in proximity to the volcanic source. The deposits included in this study include an almost 15-metre high terrace on the south side of Klutlan Glacier, near the confluence with Nesham Glacier, approximately $5 \mathrm{~km}$ west of the international border (Figure 44) and a 19-metre high terrace on the north side of Klutlan Glacier, near the confluence with Gooseneck Glacier, approximately $15 \mathrm{~km}$ west of the YukonAlaska border (Figure 45). In addition, the facies and sedimentological features of a 


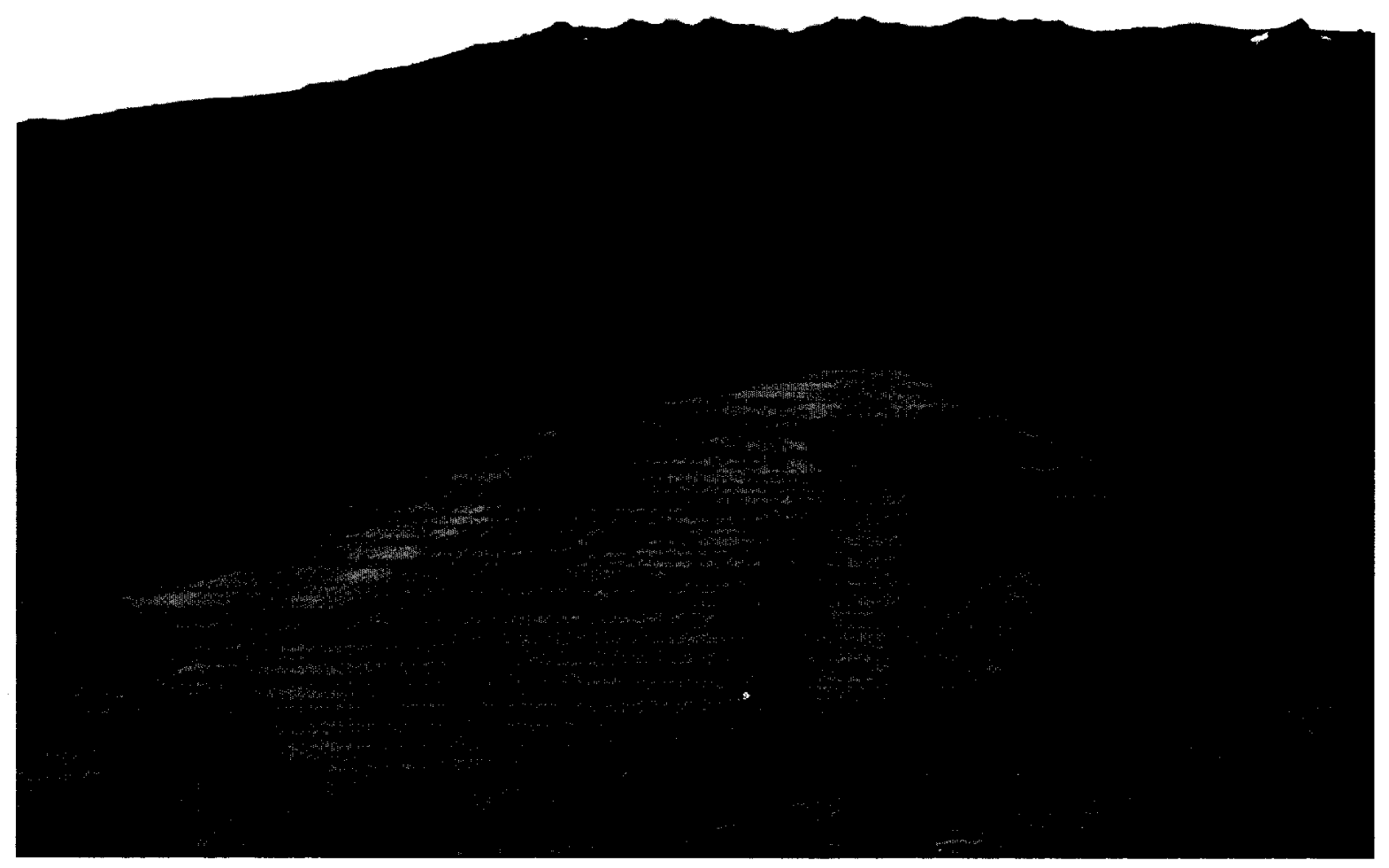

Figure 44: This terrace (Terrace 1) is located approximately $45 \mathrm{~km}$ east of Mount Churchill border on the south side of Klutlan Glacier, near the Yukon-Alaska border. It contains silt and lithic-rich interlayers in addition to ash, lapilli, and agglomerate. 


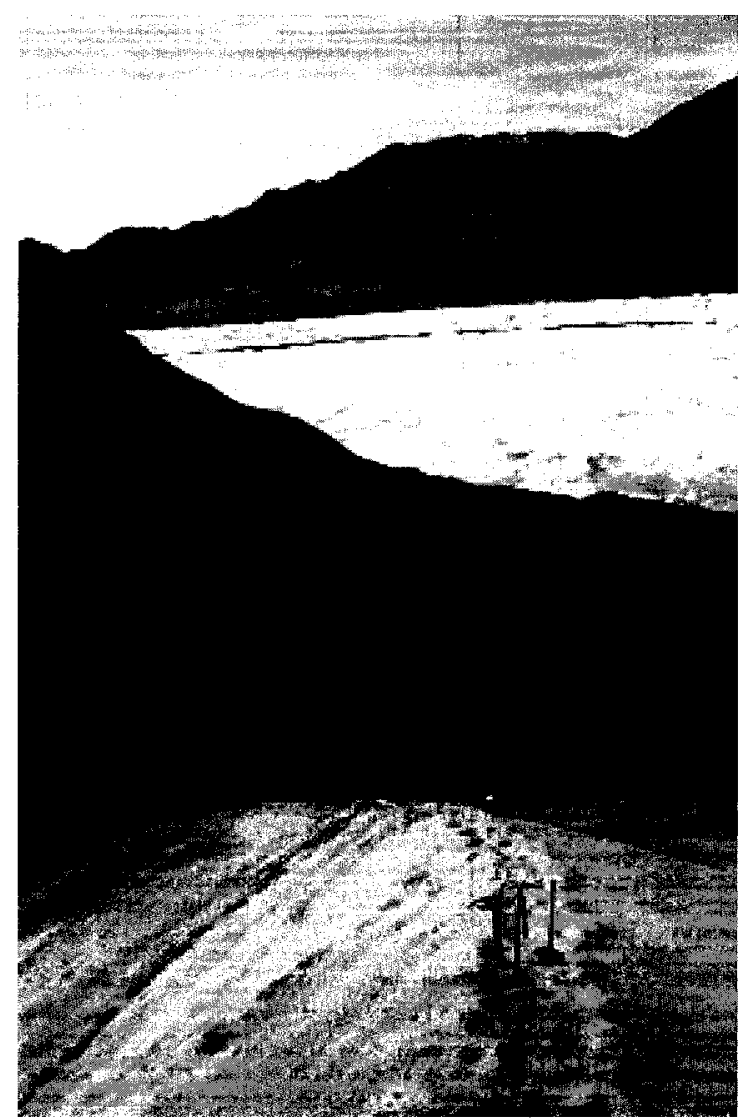

Figure 45: This terrace (Terrace 2) is located approximately $25 \mathrm{~km}$ east of Mount Churchill on the north side of Klutlan Glacier. Terrace 2 contains considerably more silt than Terrace 1 , located farther away from the volcano. 
volcaniclastic apron located at the terminus of Klutlan Glacier (N6136.516', W140 39.522') were included to further assess the depositional processes and transport mechanisms at play during the deposition and redeposition of tephra along Klutlan Glacier.

The terminology used to describe the terrace and fan deposits outlined above follows the nomenclature of Donaldson et al. (1996), Schmid (1981), and Fisher and Schmincke (1984; Figure 40). Granulometric classifications follow the descriptions of Fisher (1961) and Schmid (1981) with further subdivisions defined by Donaldson et al. (1996). Bed thickness is defined according to Ingram (1954; Figure 47). Classification and interpretation of sedimentary structures is based on the terminology of Collinson and Thompson (1989).

\section{Sample Collection}

Since the terrace and fan deposits are unconsolidated, procedures were followed to reduce the problem of collapse and allow the sampling of undisturbed layers. These procedures are described in detail in Chapter 3. Samples from the volcaniclastic fan were taken from undisturbed sections exposed in cutbanks to establish upper, mid, and lower fan facies. Similarly, the terraces were divided into lower, middle, and upper deposits, due to their size (15 to 19 meters thick). 


\begin{tabular}{|c|c|c|c|c|}
\hline & \multirow{2}{*}{$\begin{array}{c}\text { Unconsolidated } \\
\text { Pyroclastic } \\
\text { Deposit }\end{array}$} & \multirow{2}{*}{ Subdivisions } & \multicolumn{2}{|c|}{ Clast Size } \\
\hline & & & $\mathrm{mm}$ & $\Phi$ \\
\hline $\begin{array}{l}\text { Bomb, } \\
\text { Block }\end{array}$ & Agglomerate & & 64 & 6 \\
\hline \multirow{3}{*}{ Lapillus } & \multirow{3}{*}{ Lapilli } & Coarse Lapilli & 16 & -5 \\
\hline & & $\begin{array}{l}\text { Medium } \\
\text { Lapilli }\end{array}$ & $\begin{array}{l}8 \\
4\end{array}$ & -3 \\
\hline & & Fine Lapilli & 2 & -2 \\
\hline \multirow{4}{*}{$\begin{array}{c}\text { Ash Grain } \\
\text { (Shard) }\end{array}$} & \multirow{3}{*}{ Ash } & Coarse Ash & 0.5 & 0 \\
\hline & & Medium Ash & 0.25 & 1 \\
\hline & & Fine Ash & & \\
\hline & & & & \\
\hline $\begin{array}{l}\text { Dust } \\
\text { Grain }\end{array}$ & Dust & & 3 & 4 \\
\hline
\end{tabular}

Figure 46: Granulometric classification of White River ash deposits, after Schmid (1981) and used with permission from Donaldson et al. (1996). 


\begin{tabular}{|cc|}
\hline Bed & Polness \\
\hline & $<1 \mathrm{~cm}$ \\
\hline Lamina & $1-3 \mathrm{~cm}$ \\
\hline Very Thin & $3-10 \mathrm{~cm}$ \\
\hline Thin & $10-30 \mathrm{~cm}$ \\
\hline Medium & $30-100 \mathrm{~cm}$ \\
\hline Thick & $>100 \mathrm{~cm}$ \\
\hline Very Thick & \\
\hline
\end{tabular}

Figure 47: Thickness of units as defined by Ingram (1954). 


\section{Terrace Facies}

Facies within the terraces were determined using the four-tier system of grain size, matrixframework ratios, sedimentary structures, and abundance of lithic fragments utilized by Donaldson et al. (1996). This approach was taken to ensure consistency and ease of comparison between regional terrace deposits. New facies (A-5), in addition to those catalogued by Donaldson et al. (1996), are described below, and range from poorly to wellsorted deposits of ash, lapilli, agglomerate, silt, and lithics. Facies AG-9, a disorganized lithicrich agglomerate, does not appear in the terraces studied herein. Details and distinctive features of each facies are illustrated in Figures 49-59 and in Table 4.

\section{(1) Massive to Normal-Graded Vitric Cohesive Silt (S-1)}

This facies consists of planar-bedded vitric cohesive silt in units up to $30 \mathrm{~cm}$ thick (Figure 48). The light-brown silt is rich in vitric fragments, and may be massive or normal-graded. Normal-graded units are characterized by variations in color, finely interspersed pumiceous ash laminae, and scattered pumice fragments ( 1 to $2 \mathrm{~mm}$ in diameter) that accentuate the bedding surfaces. Thick units are commonly found in association with beds of ripple cross-laminated or horizontally-laminated ash (A-2), well-sorted ash (A-3), normal-graded lapilli ash (LA-5), or ungraded to inversely graded lapilli ash (LA-7). Thin discontinuous lenses of silt may be found in units of well-sorted lapilli (L-3), ungraded to inversely graded ash (A-4), normal-graded ash (A-5) and ungraded to inversely graded lapilli ash (LA-7). 


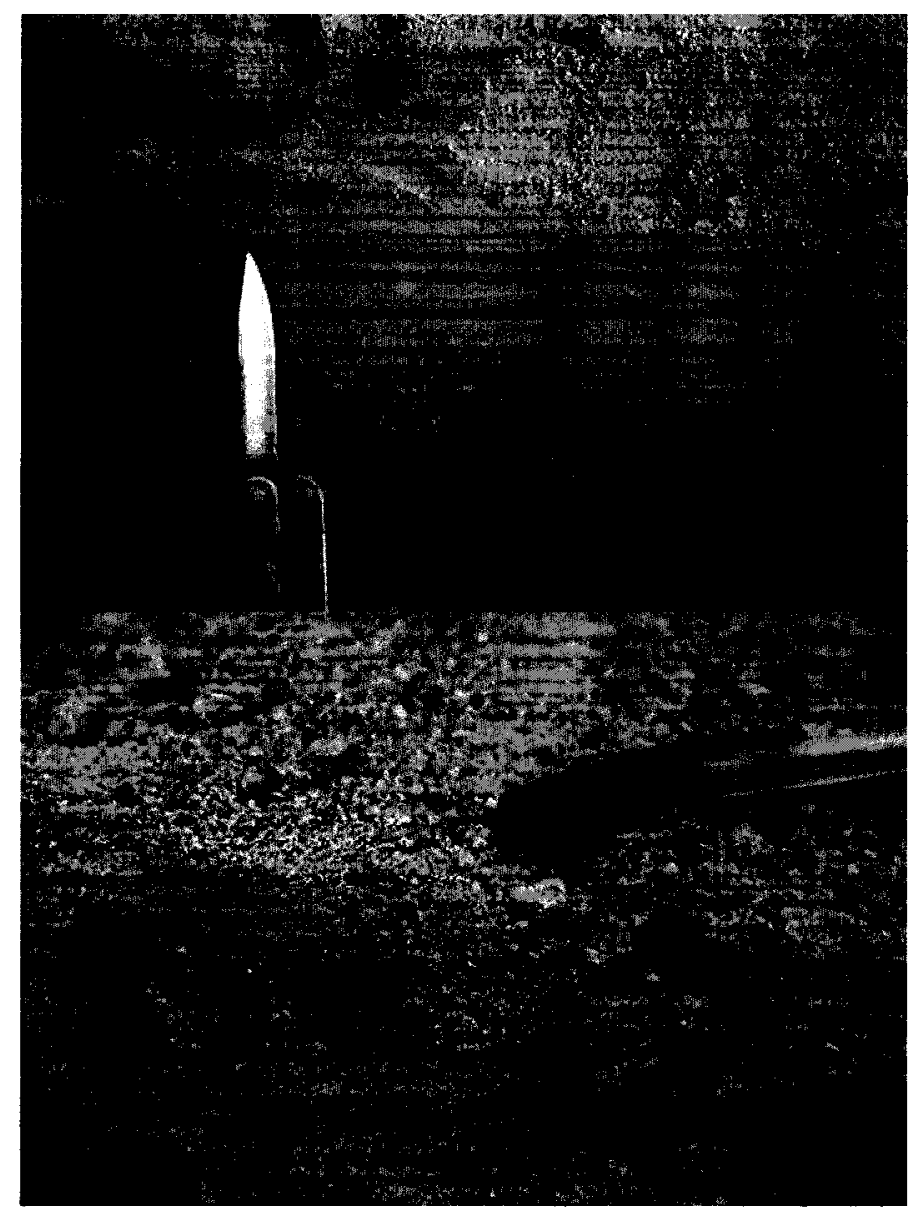

Figure 48: Thin layers of ash may occur within beds of cohesive silt (left), or cohesive silt may occur as lenses within units of ash. 


\begin{tabular}{|c|c|c|}
\hline Facies & Description & Interpretation \\
\hline $\begin{array}{l}\text { Massive to laminated or nomal- } \\
\text { graded vitric cohesive silt } \\
\text { (S-1) }\end{array}$ & $\begin{array}{l}\text { Massive to laminated or normal-graded } \\
\text { pumiceous fine sand to vitric silt }\end{array}$ & $\begin{array}{l}\text { Suspension settling (overbank, restricted } \\
\text { ephemeral lake, or waning flood } \\
\text { deposits) }\end{array}$ \\
\hline $\begin{array}{l}\text { Ripple cross-laminated and } \\
\text { horizontally laminated ash (A-2) }\end{array}$ & $\begin{array}{l}\text { Ripple cross-laminated and horizontally } \\
\text { laminated medium to fine-grained ash, } \\
\text { interlaminated with lithic-rich } \\
\text { concentrations (LA-3) }\end{array}$ & $\begin{array}{l}\text { Migration of ripples, formed by tractional } \\
\text { currents in the lower flow regime, } \\
\text { deposition under super-critical-flow } \\
\text { conditions }\end{array}$ \\
\hline $\begin{array}{l}\text { Well-sorted ash } \\
\text { (A-3) }\end{array}$ & $\begin{array}{l}\text { Well-sorted, fining upward sequences of } \\
\text { medium- to fine-grained ash, with scour } \\
\text { and lag deposits }\end{array}$ & $\begin{array}{l}\text { Lateral migration of channels; waning } \\
\text { flood deposits }\end{array}$ \\
\hline $\begin{array}{l}\text { Lithic-rich ash } \\
\text { (LA-3) }\end{array}$ & $\begin{array}{l}\text { Very thin to thin layers, ripple cross- } \\
\text { laminated or horizontally laminated, may } \\
\text { be interlaminated with A-2, A-3 and L-3 }\end{array}$ & $\begin{array}{l}\text { Migration of ripples formed by tractional } \\
\text { currents in the lower flow regime; } \\
\text { deposition under super-critical-flow } \\
\text { conditions }\end{array}$ \\
\hline $\begin{array}{l}\text { Well-sorted lapilli } \\
\text { (L-3) }\end{array}$ & $\begin{array}{l}\text { Medium- to coarse-grained beds of well- } \\
\text { sorted lapilli, often interlaminated with S-1, } \\
\text { A-2, La-3, A-4, A-5 \& LA-8 }\end{array}$ & $\begin{array}{l}\text { Subaqueous reworking of saturated } \\
\text { pumice clasts by tractional currents. }\end{array}$ \\
\hline $\begin{array}{l}\text { Laminated, ungraded to inverse- } \\
\text { graded ash } \\
\text { (A-4) }\end{array}$ & $\begin{array}{l}\text { Laminated, ungraded and (or) inversely } \\
\text { graded deposits of coarse- to medium- } \\
\text { grained ash; commonly scoured and } \\
\text { interlaminated with S- } 1, \text { LA- } 3 \text {, or L-3 }\end{array}$ & $\begin{array}{l}\text { Sheet-flow deposits (upper flow regime } \\
\text { in a floodplain environment) }\end{array}$ \\
\hline $\begin{array}{l}\text { Faintly laminated, nommal- graded } \\
\text { ash } \\
\text { (A-5) }\end{array}$ & $\begin{array}{l}\text { Faintly laminated fine- to coarse-grained } \\
\text { well-sorted ash with multiple normal } \\
\text { grading sequences }\end{array}$ & $\begin{array}{l}\text { Migration of low-relief bedforms whose } \\
\text { amplitude is limited by very shallow flow } \\
\text { depths (super-critical-flow conditions); } \\
\text { Migration of very low-angle bedforms or } \\
\text { sand sheets under upper flow regime } \\
\text { conditions }\end{array}$ \\
\hline $\begin{array}{l}\text { Grain-supported, normal- graded } \\
\text { lapilli ash } \\
\text { (LA-5) }\end{array}$ & $\begin{array}{l}\text { Normally graded fine- to coarse- lapilli in a } \\
\text { matrix of planar or x-bedded coarse- } \\
\text { grained ash; multiple grading units (coarse- } \\
\text { fine-coarse) are common as are rips-ups, } \\
\text { dropstones, and mud drapes }\end{array}$ & $\begin{array}{l}\text { Redeposition grading (the reworking of } \\
\text { saturated pumice clasts in a subaqueous } \\
\text { environment by tractional currents); late-- } \\
\text { stage suspension settling (as evidenced by } \\
\text { mud drapes) }\end{array}$ \\
\hline $\begin{array}{l}\text { Cross-bedded lapilli ash } \\
\text { (LA-G) }\end{array}$ & $\begin{array}{l}\text { Cross-bedded units of well-sorted } \\
\text { medium-grained ash, moderately-sorted } \\
\text { coarse ash, partly grain-supported fine to } \\
\text { medium lapilli and matrix-supported lapilli } \\
\text { ash }\end{array}$ & $\begin{array}{l}\text { Tractional currents in the lower flow } \\
\text { regime. }\end{array}$ \\
\hline $\begin{array}{l}\text { Ungraded to inverse-graded lapilli } \\
\text { ash (LA-7) }\end{array}$ & $\begin{array}{l}\text { Ungraded to inversely graded lapilli in a } \\
\text { matrix of fine- to coarse-grained ash }\end{array}$ & $\begin{array}{l}\text { Deposition from a highly concentrated } \\
\text { suspension of ash and lapilli or from } \\
\text { sediment-laden tractional currents, with } \\
\text { waning flow resulting in normal or } \\
\text { inverse grading depending on physical } \\
\text { particle size and density (sheetflow upper } \\
\text { flow regime deposits in alluvial fan, } \\
\text { floodplain or crevasse splays) }\end{array}$ \\
\hline $\begin{array}{l}\text { Disorganized lithic-rich lapilli ash } \\
\text { (LA-8) }\end{array}$ & $\begin{array}{l}\text { Disorganized poorly sorted lapilli in a } \\
\text { matrix of fine- to coarse-grained ash; may } \\
\text { be crudely stratified }\end{array}$ & $\begin{array}{l}\text { Rapid deposition from high } \\
\text { concentration suspension of ash and } \\
\text { lapilli; lacks sedimentary structures due to } \\
\text { tractional processes }\end{array}$ \\
\hline
\end{tabular}

Table 4: Facies of the White River terraces and their interpretations. 
Sedimentary features are quite varied; some units are pristine with minimal variations in thickness; others are irregular with obvious post-depositional modifications. The latter is common in units that are $<2 \mathrm{~cm}$ in overall thickness, or along contacts with coarser beds of lapilli or ash (e.g. well-sorted lapilli (L-3), ungraded to inversely graded ash (A-4), normal-graded ash (A-5) and ungraded to inversely graded lapilli ash (LA-7)). Overall, the characteristic features of the facies include ice-rafted pebbles, open pore spaces (where ice crystals have melted out), and sub- to well-rounded pumice clasts up to $4 \mathrm{~mm}$ in diameter (dropstones). Laminations beneath the dropstones are invariably slightly deformed, and overlying layers are typically draped over them. Some beds contain tabular, ovoid or irregular rip-ups and aggregates of very fine-grained unconsolidated ash (surmised to have formed similarly to the pumice clasts found at Donjek River, described in Chapter 2; Figures 49 and 50).

The presence of thin layers of ash, rip-up clasts, ripples, and laminations suggests that deposition occurred grain-by-grain in a low-energy environment, rather than by enmasse deposition (cf. Best 1992). Sedimentary structures such as ripple marks and planar facies are common within low-energy environments. Dropstones were likely deposited when pumice clasts became waterlogged; laminations would slightly deform beneath the clasts and drape their tops as silt deposition continued (cf. White et al. 2001, 


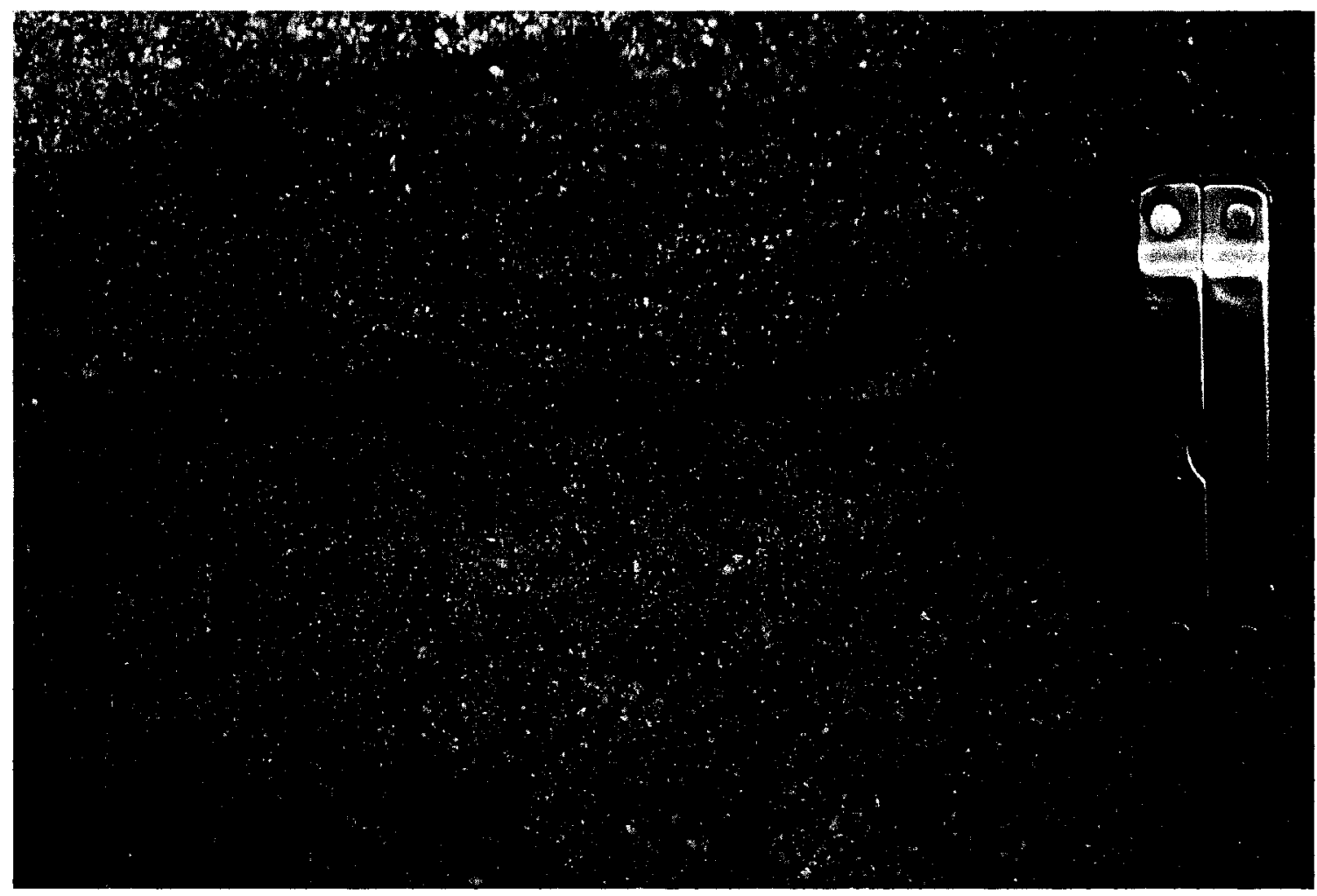

Figure 49: Irregular clasts of very fine-grained unconsolidated ash intermixed with beds of cohesive silt and horizontally laminated ash. These clasts have sharp boundaries and are internally laminated. 


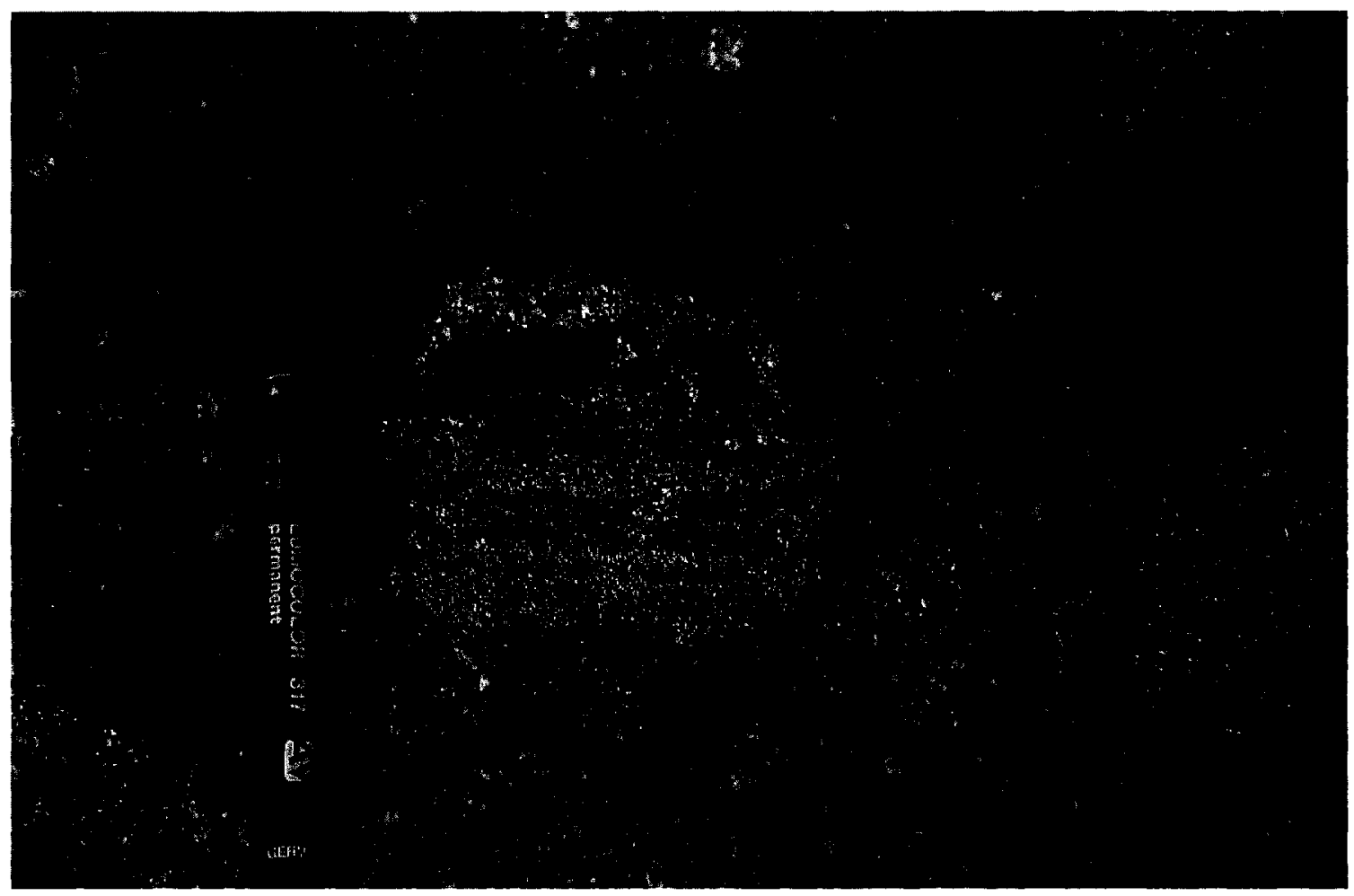

Figure 50: Internally laminated tephra clast embedded in pyroclastic sediments, proximal terrace deposit, south side of Klutlan Glacier. Pen is $8 \mathrm{~cm}$ long. 
Manville 2001). These features are attributed to suspension settling within low-energy ephemeral lakes or ponds, or abandoned river channels (cf. Collinson 1996; Smith 1991a; Segschneider et al. 2002). Rip-up clasts may have been deposited similarly to the Bock's Brook ash (initially as an airfall layer) on a subaerially exposed overbank plain. The presence of ice-rafted pebbles and pore spaces where ice crystals have melted out supports the inference that at one point the tephra was frozen. Alternatively, this facies may have formed as waning flood deposits (Miall 1978; Smith 1987; Manville et al. 2001, 2000; Kataoka and Nakajo 2002) or in a nearshore environment near a temporary lake (cf. Smith 1991a).

\section{(2) Ripple Cross-Laminated and Horizontally-Laminated Ash (A-2)}

This facies is represented by ripple cross-laminated and horizontally-laminated beds of medium- to very fine-grained, well-sorted pumiceous ash (Figure 51). Beds are typically up to $1 \mathrm{~m}$ thick, and are laterally continuous with gradational contacts. The white to light grey color of this facies contrasts sharply with predominant dark, thin, lithic-rich $(<2 \mathrm{~mm}$ diameter) cross- and horizontal-laminae (LA-3), making it one of the most conspicuous facies in the terraces. Units are typically interbedded with well-sorted ash (A-3) or lapilli (L-3), and ungraded to inverse-graded lapilli ash (LA-7). To a lesser extent, this facies may be interbedded with silt (S-1), well-sorted lapilli (L-3), ungraded to inverse-graded lapilli ash (LA-7). 


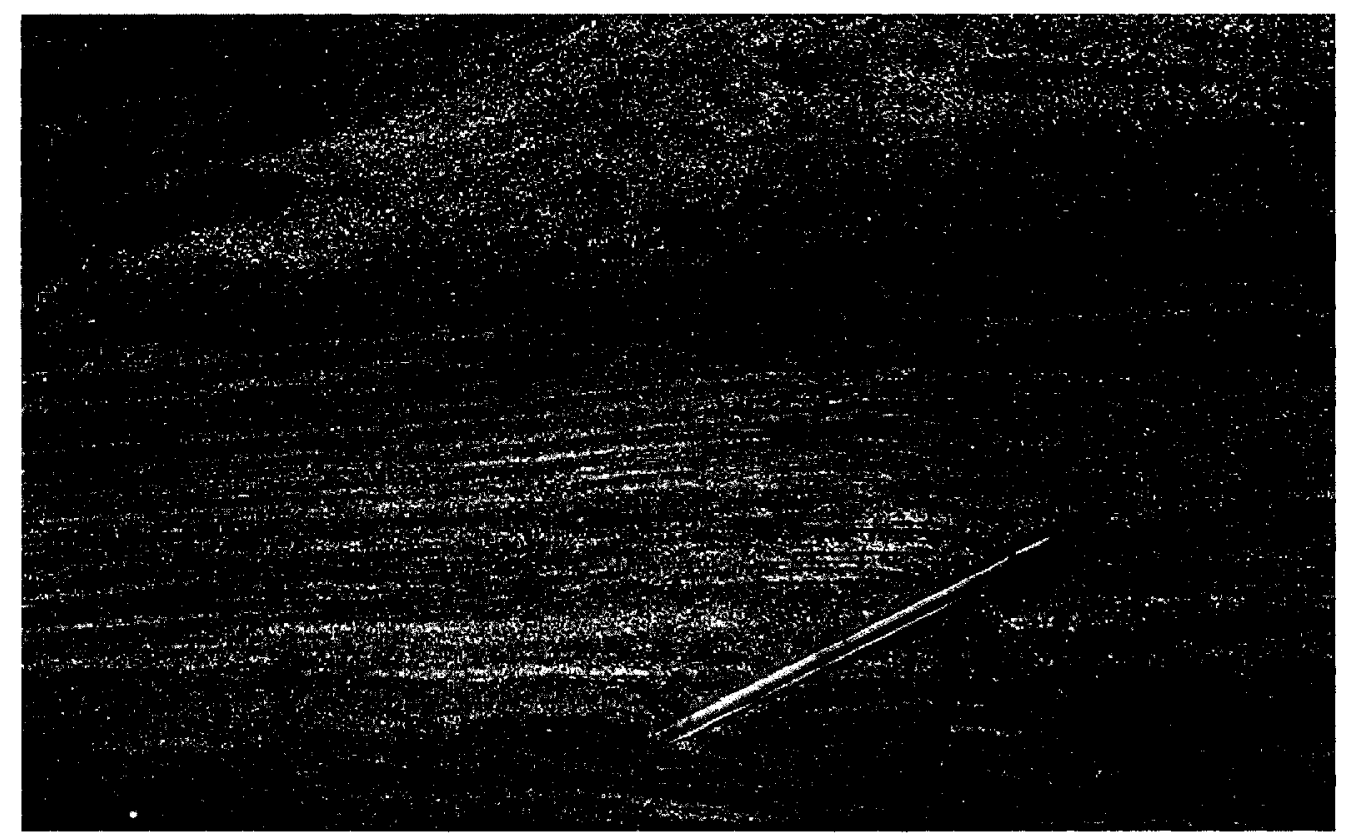

Figure 51: Horizontally or cross-laminated ash (A-2) is a common facies throughout the terrace deposits. 
Depositional features are varied within this facies and include soft-sediment deformation structures, dewatering structures, scours, channels, lensoidal structures, very fine-grained clumps of ash, upward doming of laminae, degraded pumice clasts, and ice-rafted pebbles. Some units contain scattered and (or) inverse-graded lapilli and angular lithic fragments $(<1 \mathrm{~cm}$ in diameter). Other sedimentary structures include small sets of trough cross-laminations, in association with rare climbing ripples. Asymmetric ripples indicate paleocurrents directed to the east.

Overall, the sedimentary structures of the facies, its well-sorted nature, and the subangularity to sub-rounded shape of the ash grains indicate that the sediments were fluvially deposited or reworked. In particular, these units are similar to flood-flow deposits on a floodplain, proximal to channels which may have carried coarser-grained volcaniclastic material (cf. Kataoka and Nakajo 2002). Normal and inverse-graded beds within the facies are indicative of waning or waxing flood flow velocity; finer beds were likely deposited during inter-flood intervals (cf. Kataoka and Nakajo 2002). The presence of cross-laminated ash and asymmetric ripples suggests the presence of unidirectional tractional currents in the lower flow regime (cf. Segshneider et al. 2002; Manville 2001). Low-angle cross-beds in fluvially deposited fine to coarse sand sediments are often interpreted to represent scour-fill and antidune deposits (cf. Smith 
1987). Horizontally laminated fine- to medium-grained ash may have been deposited under super-critical-flow conditions (restricted flow height; cf. Segschneider et al. 2002).

\section{(3) Well-Sorted Ash (A-3)}

This facies comprises well-sorted, planar-bedded sequences of medium- to fine-grained pumiceous ash in beds up to $12 \mathrm{~cm}$ thick (Figure 52). The ash ranges in color from white to various hues of grey, buff and brown. This coloration is related to the relative abundance of silt and clay grains. Thick beds largely occur in association with finergrained facies (S-1 or A-2) in the terraces or less commonly, with coarse lenses of wellsorted lapilli (L-3). Some units are capped by thin lithic-rich laminae (LA-3), or occur as discontinuous lenses in coarser-grained deposits of ungraded to inverse-graded lapilli ash (LA-7) or disorganized lithic-rich lapilli ash (LA-8).

Sedimentary structures within this facies are minimal. Most units are massive; however, some are locally cryoturbated or crudely stratified. The deposit contains sub-angular to sub-rounded grains of ash and sparse lithic fragments (2-3\%), which occur primarily as angular fragments less than $8 \mathrm{~mm}$ in diameter. Characteristic features of the facies include normal grading, inverse-to-normal-graded sequences, irregular basal contacts, channeled erosive bases, and lateral variations in thickness. Some beds contain irregular 


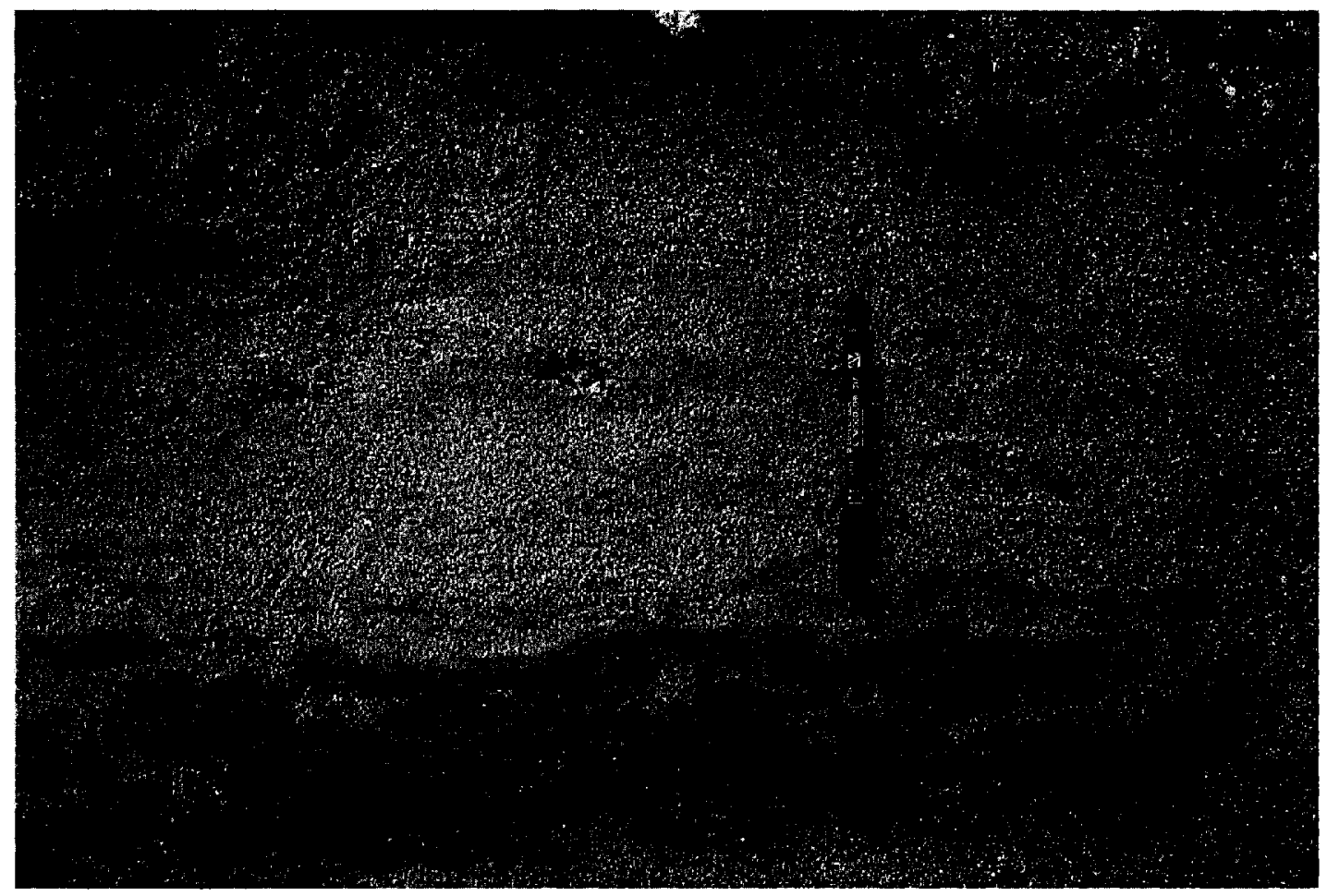

Figure 52: Well-sorted ash (A-3) appears above a bed of cohesive silt (S-1). 
scour surfaces within which larger pumice clasts $(<1 \mathrm{~cm})$ are concentrated (lag deposits). Beds displaying a lack of traction structures, poor sorting, crude stratification, inverse-to-normal-grading, coarse lenses, and features indicating a greater degree of turbulence (compared to debris flow deposits) are characterized as hyperconcentrated flood flow deposits (Manville et al. 2001; Smith 1991a). The well-sorted nature of this facies, its graded sequences, lag deposits and channel structures suggest that it was deposited fluvially rather than as a hyperconcentrated flood flow. The lenses of wellsorted coarse ash suggest that local turbulence occurred in the depositional environment (Smith 1991a). In particular, the grading sequences suggest the active lateral migration of channels or the deceleration of flow in waning channels while the lag deposits and channel structures are reminiscent of fluvial channel-fill deposits (cf. Kataoka and Nakajo 2002). Furthermore, the close association of this facies with finer-grained fluvial deposits in the terraces also points towards a waning flow velocity.

\section{(4) Lithic-Rich Ash (LA-3)}

This facies is characterized by thin $(<5 \mathrm{~cm}$ thick) beds of dark, lithic-rich cross- or horizontal-laminae (Figure 53). Minor amounts of coarse pumiceous ash, sand and inverse-graded subrounded pumice lapilli $(<1 \mathrm{~cm}$ diameter) occur amongst the lithic fragments. Lithic grains are normal-graded, predominantly black to grey, and consist 


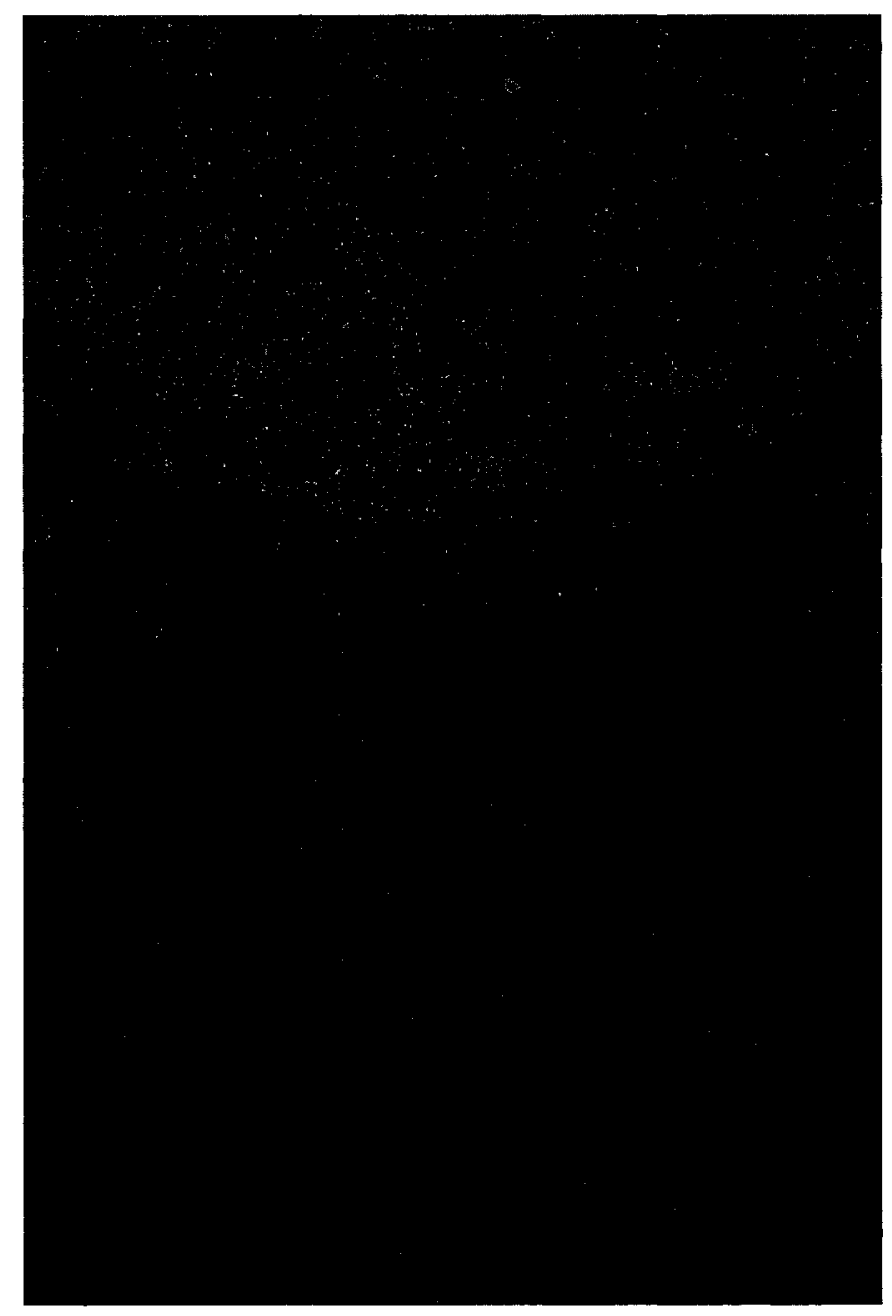

Figure 53: Dark lithic-rich layers (LA-3) are commonly interlayered with fine-grained beds of well-sorted ash (A-3). 
primarily of angular mafic fragments $<7 \mathrm{~mm}$ in diameter. Overall, the unit is poorly sorted, with lithic grains concentrated near the base of foresets in cross-laminated or cross-bedded units. Deposits of LA-3 are widespread throughout the terraces, and occur in close association with ripple cross-laminated and horizontally laminated ash (A2), well-sorted ash (A-3), well-sorted lapilli (L-3), ungraded and (or) inverse-graded ash (A-4), grain-supported normal-graded lapilli ash (LA-5), cross-bedded lapilli ash (LA-6), ungraded to inverse-graded lapilli ash (LA-7), and disorganized lithic-rich lapilli ash (LA$8)$.

Similar lithic-rich horizontally stratified sediments have been interpreted by various authors to have formed by: 1) migration of low-relief bedforms (i.e. ripples), formed by tractional currents in the lower flow regime (Segschneider et al. 2002); 2) migration of very-low-angle bedforms in the upper flow regime (Tunbridge 1981; Allen 1984; Bridge and Best 1988, 1997; Paola et al. 1989; Manville et al. 2001); 3) deposition under supercritical flow conditions (maximum of a few centimeters in an ephemeral stream) (Smith 1971; Manville et al. 2001); 4) grain-by-grain deposition from hyperconcentrated flood flow (Beverage and Culbertson 1964; Pierson and Scott 1985; Manville et al. 2001); or 5) the input of streams or storms in lagoonal or lacustrine environments (Riggs et al. 2001). Similarly, cross-laminated or low-angle cross-bedded lithic-rich deposits are surmised to have formed from the migration of low-angle bedforms under upper flow regime 
conditions and the infilling of erosional scours in shallow braided streams (Picard and High 1973; Miall 1977, 1978; Rust 1978; Manville et al. 2001). The overwhelming presence of cross-laminae and cross-bedding in this facies, however, attests to an origin that is distinct from flows with higher sediment concentrations (hyperconcentrated flood, debris flow, or flood deposits; Smith 1991a) or sediments formed in non-fluvial low-energy environments (lagoonal or lacustrine sediments). The widespread occurrence of this facies with beds of ripple cross- and horizontally-laminated ash (A-2) supports a fluvial origin under fluctuating or super-critical-flow conditions.

\section{(5) Well-sorted Lapilli (L-3)}

This facies, one of the coarsest deposits in the terraces, comprises grain-supported beds of sub-rounded to rounded pumiceous lapilli, lacking fine- to coarse-grained ash, in units up to $84 \mathrm{~cm}$ thick (Figure 54). Lapilli are predominantly medium- to coarse-grained (few units contain finer fragments), and may be normal-graded, reverse-to-normalgraded, or faintly laminated. Individual beds are typically light grey to white, but include shades of buff, beige, or brown if clay is present. Some units contain dropstones, frostshattered pumice clasts, or sparse populations of lithic fragments $(<1 \%)$. This facies is often planar-laminated with silt (S-1), ripple cross-laminated and horizontally laminated ash (A-2), lithic-rich ash (LA-3), ungraded and (or) inverse-graded ash (A-4), normalgraded ash (A-5) and disorganized lithic-rich lapilli ash (LA-8). It may also occur as 


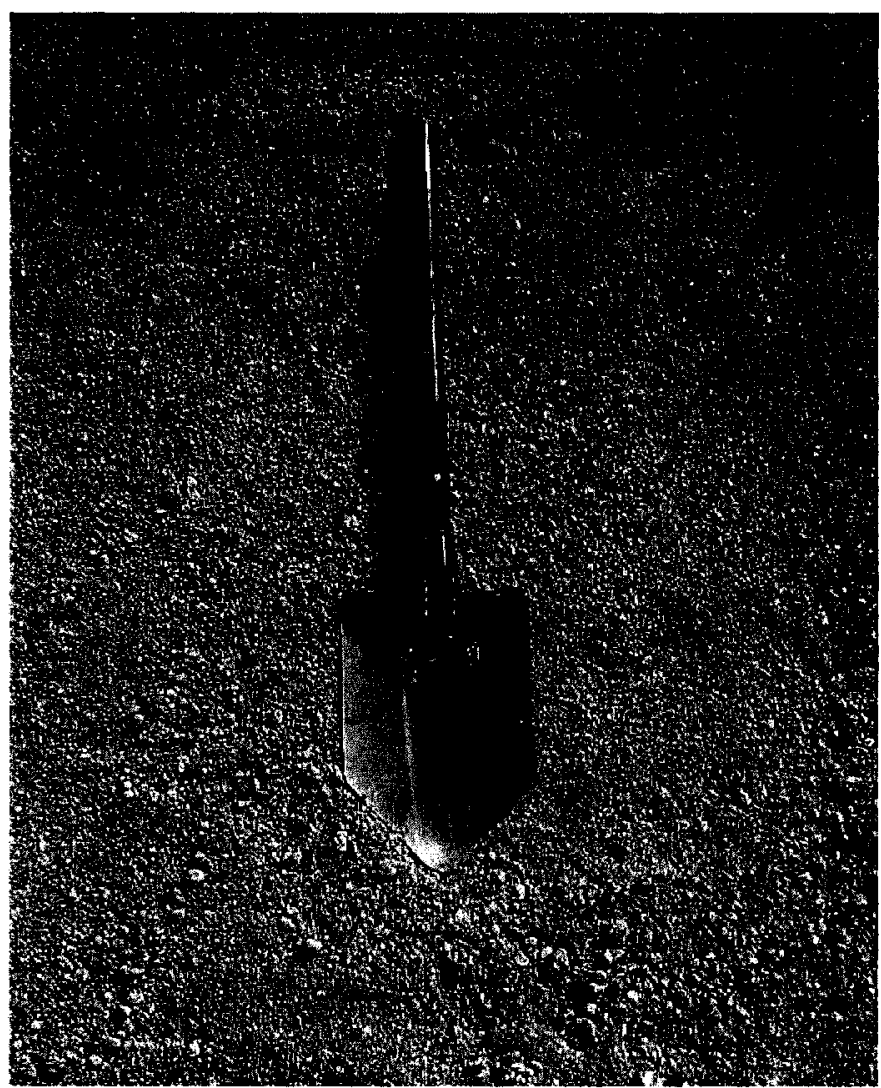

Figure 54: Facies L-3 is composed of well-sorted lapilli. 
discontinuous lenses in ripple cross-laminated and horizontally laminated ash (A-2), well-sorted ash (A-3), and ungraded and (or) inverse-graded ash (A-4). In this facies a predominance of medium- to coarse-grained, openwork, matrix-free lapilli might initially lead one to infer that the deposit formed as part of a primary fall unit. However, the coarse-grained nature of the lapilli fragments, in combination with the geographic distance of the terraces from the volcanic source $(30$ or $50 \mathrm{~km}$ ), suggests that such an origin is unlikely. The predominance of silt, ash, and lapilli ash interlaminae suggests that this facies formed in a subaqueous environment where reworking of saturated pumice clasts by tractional currents occurred and where finer sediments could accumulate during periods of low-energy or waning flood velocity (cf. Manville et al. 2001). Similar sediments of pumiceous lapilli, accumulated in deposits of Lake Taupo, have been interpreted as beach berm deposits (cf. Manville et al. 2001).

\section{(6) Laminated, Ungraded to Inverse-Graded Ash (A-4)}

This facies is characterized by ungraded to inversely graded deposits of coarse- to medium-grained, pumiceous ash. Beds are typically up to $127 \mathrm{~cm}$ thick, and are lateraily continuous, with sharp underlying contacts. Minor constituents include sub-rounded pumice lapilli $(<2 \mathrm{~cm}$ diameter; $2-5 \%)$ and lithics $(<1 \mathrm{~cm}$ diameter; $2-5 \%)$. Thick cream to beige or grey-colored units display repeated sequences of horizontally laminated and inverse-graded ash capped by thin $(<5 \mathrm{~mm})$ interlaminae of cohesive silt $(\mathrm{S}-1)$, lithics 
(LA-3) or well-sorted lapilli (L-3). Thin lenses of this facies typically occur in association with coarser beds of well-sorted lapilli (L-3).

Sedimentary structures within this facies include inverse grading of pumice lapilli and ash, and normal grading of lithic fragments. Ungraded deposits display faint horizontal laminations. In some places units are locally scoured, and display variations in lateral thickness. Beds may have originated as upper flow regime sheet-flow deposits in a floodplain environment. Pumice clasts, with a higher density than that of the sand and water, display inverse grading, while the lithic fragments display normal grading. The cohesive silt layers within the deposit would probably represent late-stage suspension settling (Segschneider et al. 2002).

\section{(7) Faintly Laminated, Normal-Graded Ash (A-5)}

This facies comprises planar-laminated beds of normal-graded fine- to coarse-grained ash and is rare in the terrace deposits. Most of the light-grey or beige/brown units, up to $120 \mathrm{~cm}$ thick, are faintly laminated or cryoturbated. These units typically display good sorting with multiple graded sequences capped by discontinuous laminae of silt (S-1). Beds may be interlaminated with cohesive silt deposits (S-1), ripple cross-laminated or horizontally laminated ash (A-2) and lithic-rich ash (LA-3). Some units may also occur 
as tabular units or lenses within thick sequences of ungraded to inverse-graded lapilli ash (LA-7) or well-sorted lapilli (L-3).

Similar pumice-rich normal-graded sediments have been interpreted as a response to: 1) deposition under super-critical flow conditions (maximum of a few centimeters in an ephemeral stream; cf. Manville 2001); 2) the migration of very-low-angle bedforms in upper flow regime conditions; or 3) rapid deposition from hyperconcentrated flood flow (cf. Smith 1987). It is unlikely, however, that these sediments are derived from hyperconcentrated flood flows, as tractional structures are too well-formed. Therefore, these sediments were likely rapidly deposited in upper flow regime or super-critical-flow conditions.

\section{(8) Grain-Supported, Normal-Graded Lapilli Ash (LA-5)}

This facies is characterized by normal-graded lapilli in a matrix of coarse-grained, planarbedded ash (Figure 55). Individual beds are up to $60 \mathrm{~cm}$ thick and are well-sorted. Ash grains are beige in color, indicating a minor silt component, and are sub-angular to subrounded. Lapilli are more pristine, grey-white in color and are sub-rounded to rounded. Lithics are present throughout the deposit and may be inversely graded, so that the top portion of the units are the most lithic-rich. The facies may be interlaminated with 


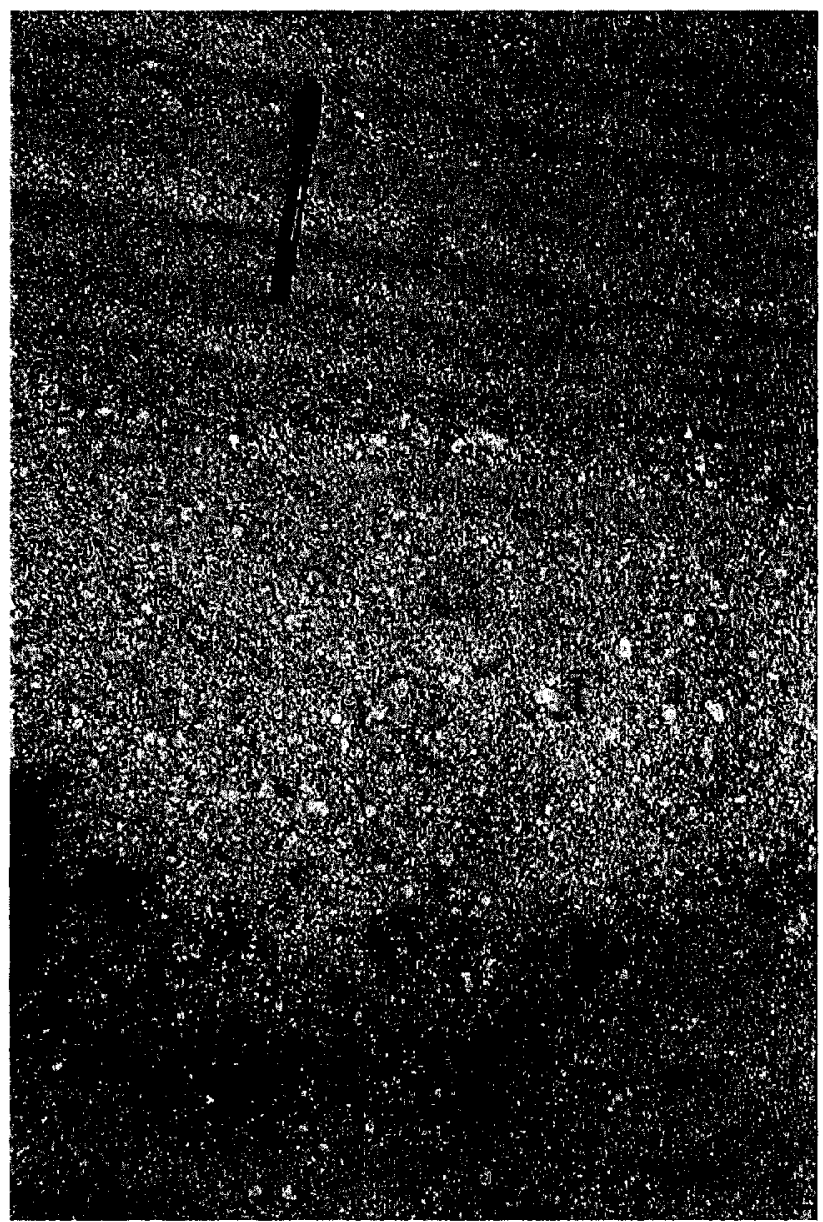

Figure 55: Normally graded lapilli ash (LA-5) overlain by horizontally and ripple cross-laminated ash (A-2). 
cohesive silt (S-1), ripple-cross laminated and horizontally laminated ash (A-2) and lithicrich ash (LA-3).

Features of the deposit include subtle horizontal laminations, coarse-fine-coarse grading couplets, dropstones, mud drapes, pumice clasts, and clay rip-ups. Some units are planar; others occur as low-angle cross-beds. Some units contain disintegrating pink pumice clasts, high density pumice clasts, irregular downloading features of the overlying ash, and channels. This facies is interpreted to have formed by reworking of saturated pumice clasts (which behave like lithics once they become denser than water) in a subaqueous environment by tractional currents (Manville et al. 2001). Deposition probably took place in a nearshore environment with periods of low-energy represented by interlaminae of silt and mud drapes (cf. Miall 1992).

(9) Cross-Bedded Lapilli Ash (LA-6)

This facies is represented by thick, distinctly cross-bedded units of well-sorted mediumgrained ash, moderately-sorted coarse ash, and matrix-supported lapilli ash (Figure 56). Thin, lithic-rich layers (LA-3) and rounded pumice lapilli commonly predominate near the tops of this deposit as well as near the base of the ripples. The lapilli ash consists of fine- to coarse-grained subrounded to rounded lapilli, which may be reversely graded, in a matrix of fine- to coarse-grained grey to brown ash. The ash units are also grey to 


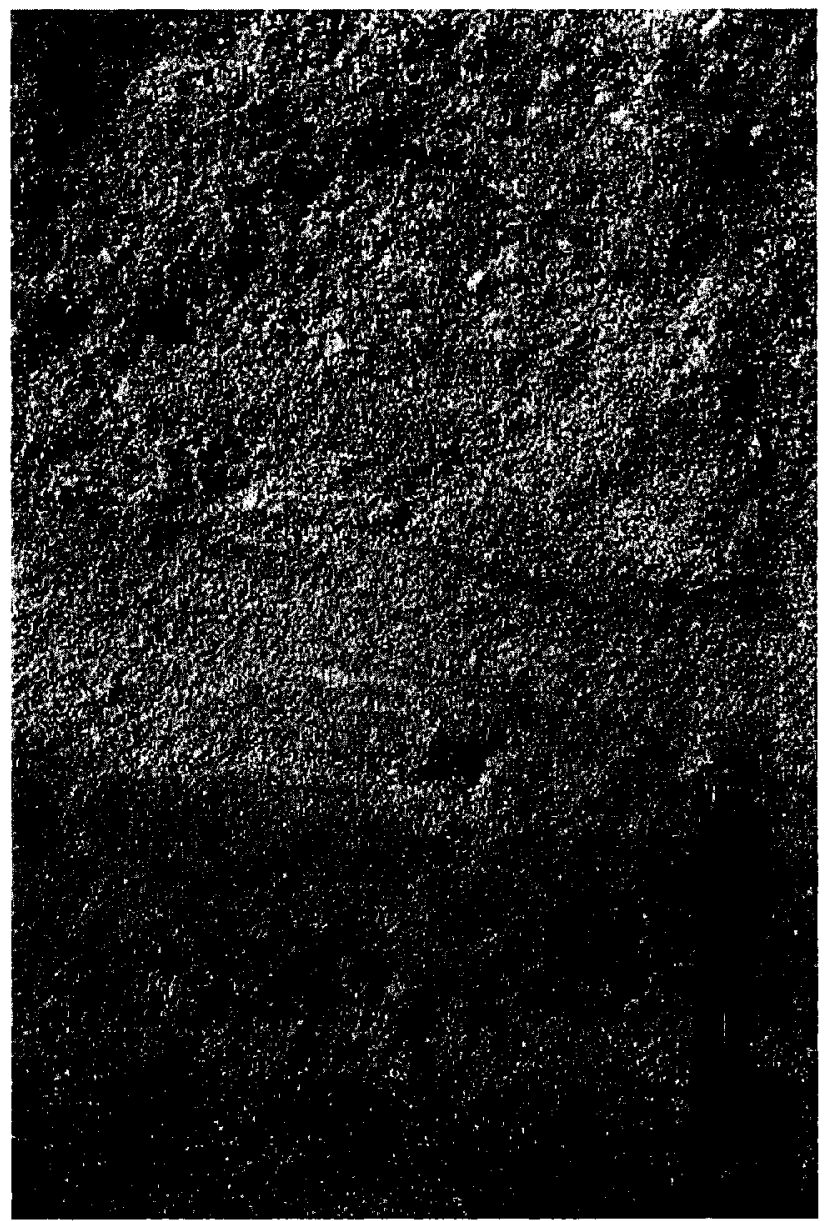

Figure 56: Cross-bedded lapilli ash (LA-6) above a unit of silt (S-1). 
brown and are composed of sub-angular to rounded grains. The deposit is capped in places by cohesive silt (S-1), and may contain lenses of ungraded to inverse-graded lapilli ash (LA-7).

Large-scale cross-beds characterize this facies, forming undulations with wavelengths up to $40 \mathrm{~cm}$ and amplitudes less than $5 \mathrm{~cm}$. Most units exhibit an undulating planar top with a scoured base and minor channels. Some units contain weathered, in situ pumice clasts, and rounded clasts of angular lithics. Distinctly cross-bedded units are indicative of fluvial deposits, and this facies likely formed in a stream environment. Since beds are predominantly lithic-rich with concentrations near the base of foresets, it is likely that these facies formed from tractional currents in the lower-flow regime (cf. Smith 1987; Smith 1987; Segschneider et al. 2002).

(10) Ungraded to Inverse-Graded Lapilli Ash (LA-7)

This facies consists of ungraded to inverse-graded lapilli, in a well-sorted matrix of fineto coarse-grained ash (Figure 57). Individual units may be up to $120 \mathrm{~cm}$ in thickness, and range in color from grey-white to buff or tan, if silt is present. Lapilli are subrounded to rounded, with smaller clasts exhibiting a more angular form. Interlaminae of silt (S-1) and ripple cross-laminated or horizontally laminated ash (A-2) are common in ash-rich regions, as are discontinuous lenses of cohesive silt ( $\mathrm{S}-1)$, ripple cross-laminated 


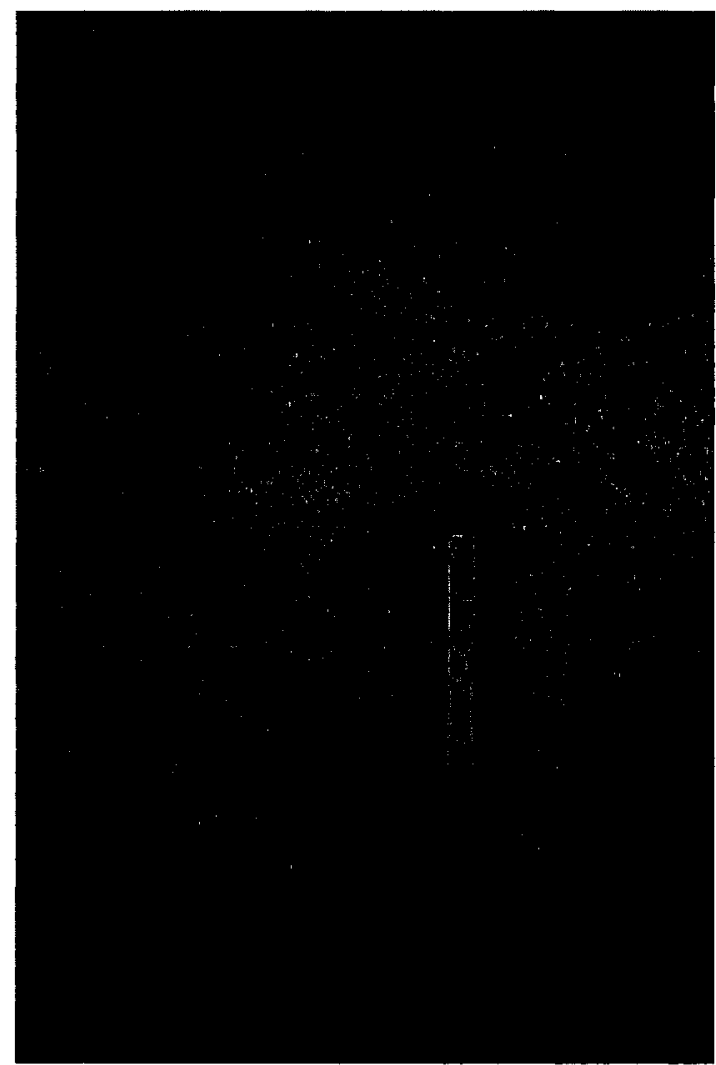

Figure 57: Ungraded to inversely graded lapilli ash (LA-7) is very common throughout the terrace deposits. 
and horizontally laminated ash (A-2), well-sorted ash (A-3), lithic-rich ash (LA-3), and normal-graded ash (A-5). This facies typically grades into units of cohesive silt (S-1) or laminated ash (A-2) and may occur as thin lenses in cross-bedded lapilli ash (LA-6).

Individual units may be inverse-graded from bottom to top, contain fining upward couplets of reverse-graded subunits, or may be inverse-to-normal-graded. Other features include weathered rounded pink pumice clasts, smaller fractured pumice clasts, and dropstones. Basal contacts are irregular and the facies usually exhibits a sharp planar top. Some beds are capped with a layer of silt rich in pumice lapilli clasts (up to $1 / 2 \mathrm{~mm}$ maximum diameter). Lithics comprise less than $15 \%$ of the unit and are composed primarily of angular mafic and exotic fragments $<3 \mathrm{~mm}$ to $1 \mathrm{~cm}$ in diameter.

This facies is interpreted to have formed in one of several ways: 1) from deposition of a highly concentrated suspension of ash and lapilli (Sohn and Chough 1989); 2) from deposition from sediment-laden tractional currents; in this case, waning flow resulting in normal grading or inverse grading depending on physical particle size and density; 3) from deposition of hyperconcentrated flood flows (cf. Manville et al. 2001). Of the three, it is less likely that this facies formed from a hyperconcentrated flood flow, because of the predominance of silt and fine ash layers in many of the units. Inverse grading likely resulted from the lower density of pumice lapilli in the deposit as tractional 
currents deposited sediment in a waning flood environment (cf. Manville et al. 2001). These deposits could alternatively be interpreted as sheetflow deposits, formed in the upper flow regime, in which case the cohesive silt interlaminae would represent periods of late-stage suspension (cf. Segschneider et al. 2002).

\section{(11) Ungraded to Inverse-Graded Agglomerate (AG-7)}

This facies is represented by one bed in the terrace deposits; this light buff unit is composed of pumiceous blocks in a matrix of unsorted and ungraded ash and lapilli and is $25 \mathrm{~cm}$ thick (Figure 58). The deposit, in most places, is extremely disorganized and very poorly sorted. It contains sparse dropstones and clusters of disintegrating pumice lapilli, and is capped by a lithic-rich layer. Locally, this unit does not contain any lithic fragments. The pumiceous blocks are up to $8 \mathrm{~cm}$ in diameter, subangular to wellrounded, and vesicular.

This facies may have been deposited from a high-concentration suspension of ash and lapilli. Tractional processes were probably lacking due to the overall lack of sedimentary structures (cf. Sohn and Chough 1989). The lack of sedimentary structures and crude stratification might suggest initially that this unit may have been deposited by a debris flow; however, the presence of dropstones indicates that this facies must have formed in a low-energy environment. This facies is therefore interpreted to have formed from 


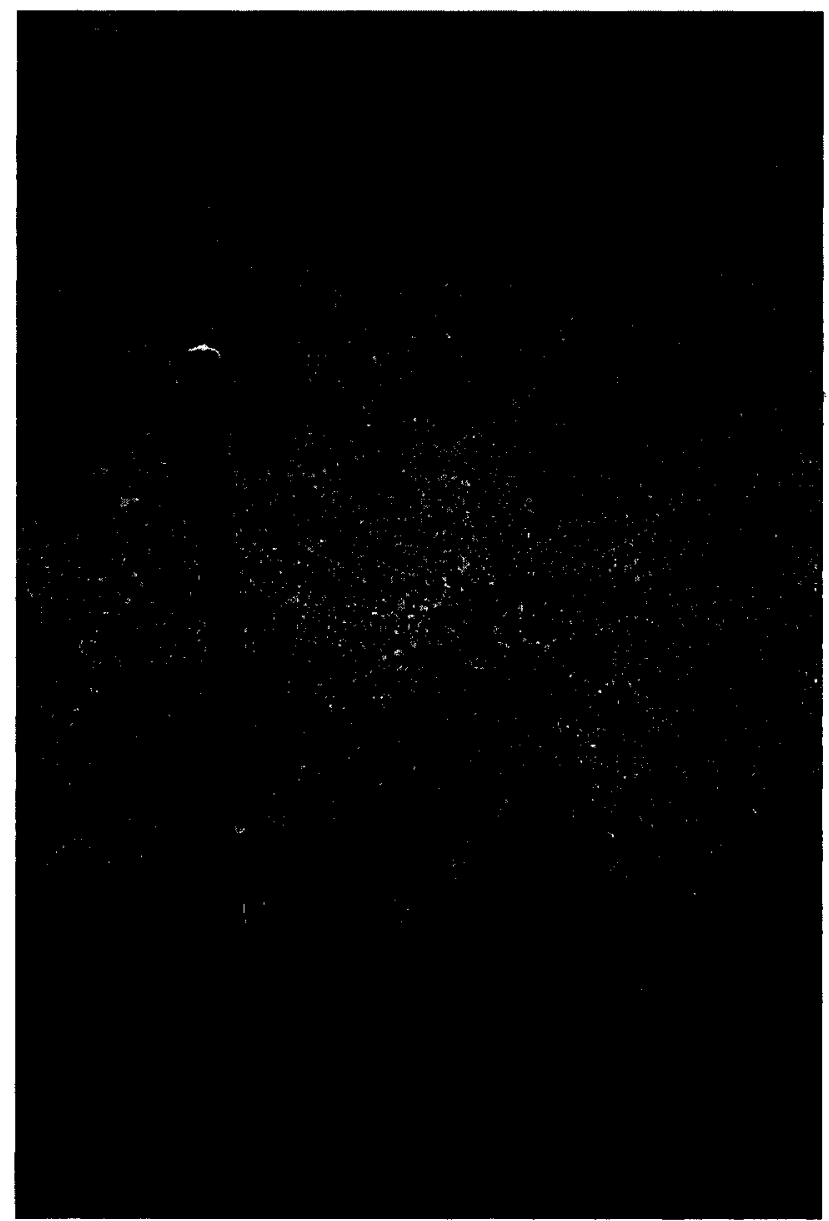

Figure 58: Coarse beds like Facies AG-7 (ungraded to inversely graded agglomerate) are not common in the terrace deposits. 
'saturation grading', or sequential settling of saturated pumice clasts in an aqueous

environment (cf. Manville et al. 2001).

\section{(12) Disorganized Lithic-rich Lapilli Ash (LA-8)}

This light grey facies, present only in Terrace 1, is characterized by poorly sorted, disorganized lithics and pumice lapilli in a matrix of fine- to coarse-grained ash. It may be up to $28 \mathrm{~cm}$ thick. Ash grains are poorly sorted and sub-angular; lapilli are predominantly sub-angular but larger grains may be rounded. Some units are interlaminated with units of lithic-rich ash (LA-3) and well-sorted lapilli (L-3). The deposit may also contain lenses of discontinuous lenses of well-sorted ash (A-3).

This deposit is variable in thickness and may be crudely stratified. It is lithic-rich, and contains up to $25 \%$ lithic fragments, which are distributed mostly in the upper portion of the units, or scattered throughout. Some units are crudely stratified, but others are interlaminated with lithics (LA-3) or well-sorted lapilli (L-3). Lithics are predominantly mafic, and less than $1 \mathrm{~mm}$ to $5 \mathrm{~cm}$ in diameter. Small lithics are rounded but the large lithics are angular. This facies was deposited rapidly from a high-concentration suspension of ash and lapilli, or from debris-flow deposits of remobilized material (cf. Manville et al. 2001). Bedding sags associated with some blocks may indicate ballistic emplacement, but given the distance from the volcanic source $(50 \mathrm{~km})$ this is not likely (cf. Sohn and Chough 1989). 


\section{Stratigraphy}

\section{Terrace 1, Lower Deposits}

The lower deposits of Terrace 1, on the south side of Klutlan Glacier (approximately 45 $\mathrm{km}$ from Mount Churchill), are composed predominantly of ripple cross-laminated and horizontally laminated ash (A-2) and ungraded to inversely-graded lapilli ash (LA-7; Figure 59). A significant proportion of units are interlayered with thin to very thin layers of lithic rich ash (LA-3) and horizons of silt (S-1). These lithic-rich layers (LA-3) primarily occur in association with facies A-2, and to a lesser extent with facies LA-5, LA-6, LA-8, and S-1.

The silt (S-1) in the lower deposits occurs as thin discontinuous lenses and clay drapes in ripple cross-laminated and horizontally laminated ash (A-2) and in grain-supported normal-graded ash (LA-5), or as thick 2-5 cm laminated or varved units. In a silt layer associated with facies A-2, near the base of the terrace deposit, irregular clasts of very fine-grained unconsolidated ash occur (Figures 49 and 50). The clasts, approximately 4 $\mathrm{mm}$ thick and $3 \mathrm{~cm}$ in diameter, are internally laminated, angular, and sharply truncated on one side. To have escaped reworking, these clasts were likely frozen and deposited when still ice-cemented, similar to the clasts observed at the Donjek River site (Chapter 2). 


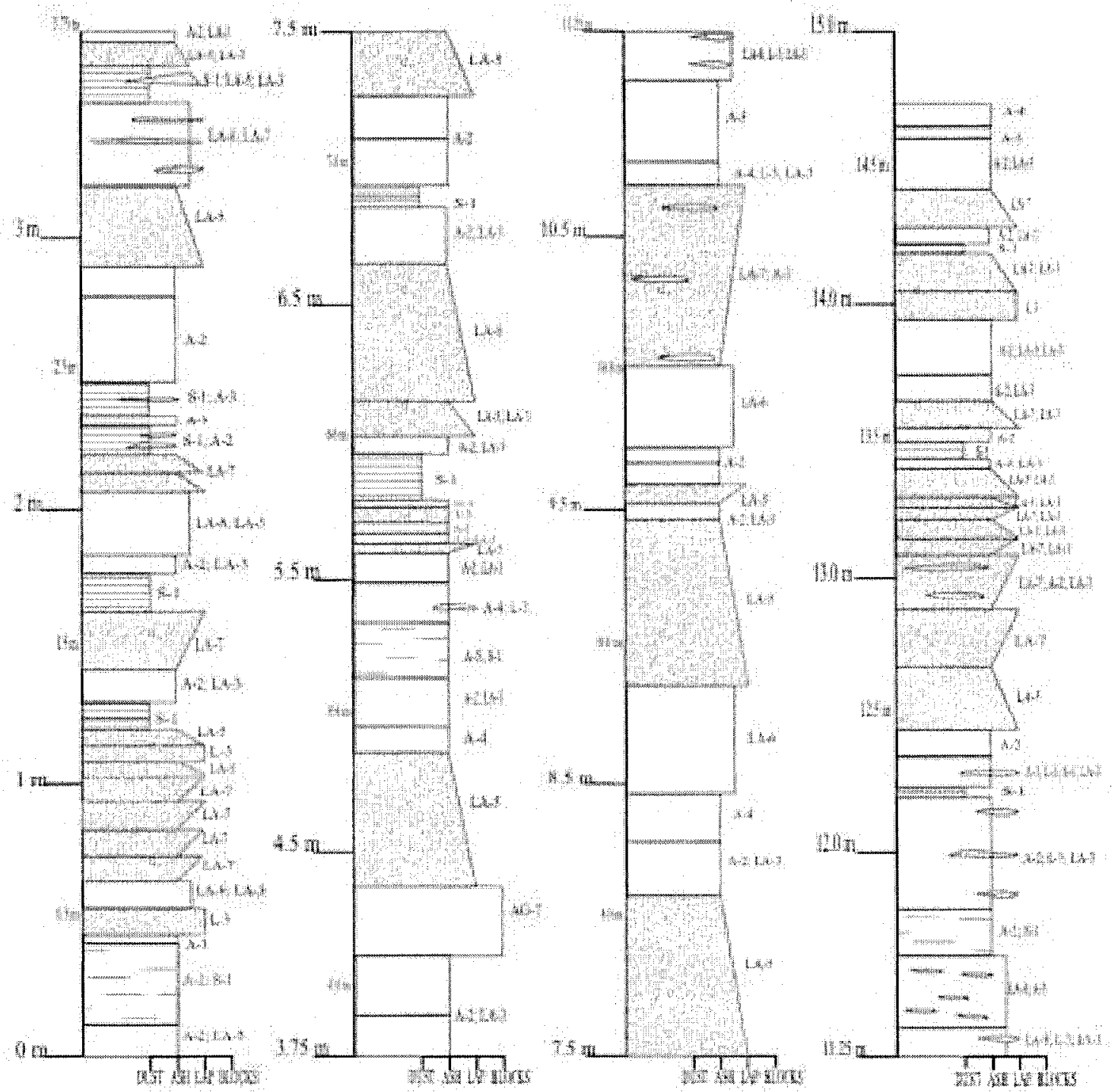

Figure 59: Stratigraphy of the upper, middle, and lower deposits of Terrace 1, a 15-meter thick terrace located on the south side of Klutlan Glacier, near the confluence with Nesham Glacier, approximately $5 \mathrm{~km}$ west of the Yukon-Alaska border. Note the predominance of horizontally laminated and ripple cross-laminated units throughout this terrace deposit. 
Well-sorted ash and lapilli in the lower deposits are punctuated periodically by the deposition of massive deposits, including a unit of disorganized, lithic-rich lapilli ash (LA-8) mid-way through the lower deposits, and a unit of ungraded to inverse-graded agglomerate (AG-7) near the top of the lower deposits. Both units are very poorly sorted and disorganized, containing a variety of ash, lapilli, and in AG-7, pumiceous blocks up to $8 \mathrm{~cm}$ in diameter. Larger-sized lapilli are rounded in both facies and most clasts are sub-angular. Facies LA-8 contains a variety of 1-5 mm-sized lithics, and is crudely stratified with facies LA-3. Facies AG-7 does not contain any lithic fragments but is capped by a lithic-rich layer, and contains dropstones and clusters of disintegrating lapilli.

\section{Terrace 1, Middle Deposits}

The middle deposits are composed of alternating units of ash (predominantly A-2, with some units of A-4 and A-5) and thick deposits of grain-supported, normal-graded lapilli ash (LA-5; Figure 59). Overall, the middle deposits contain a lower proportion of silt interlayers (S-1) than the lower deposits, suggesting a higher degree of energy and/or flow. Thick units of silt $(5-10 \mathrm{~cm})$ suggest that the middle deposits were punctuated by periods of quiescence in which suspension settling may have occurred. The abundance of ripple-and-horizontally laminated ash A-2), cross-bedded lapilli-ash (LA-6), and 
interlayers of lithic-rich ash (LA-3) indicates strong tractional currents in the lower flow regime. Thick units suggest that transport processes may have stabilized (to some extent) throughout deposition. The lack of poorly sorted or disorganized units, in combination with minimal intermixing of facies and the predominance of well-sorted, grain-supported, normal-graded ash and lapilli units suggests that redeposition grading may have occurred throughout deposition of the middle units.

\section{Terrace 1, Upper Deposits}

The upper deposits are somewhat more complex in composition than the lower or middle deposits, since they tend to include a wider variation in facies and facies associations. The upper deposits are characterized by the predominance of ripple crosslaminated and horizontally laminated ash (A-2), ungraded to inversely-graded lapilli ash (LA-7), thin to very thin lithic-rich interlayers (LA-3), grain-supported normal-graded lapilli ash (LA-5) and well-sorted lapilli (L-3; Figure 59). The lithic-rich layers occur in association with several well-sorted ash units (A-2, A-3, A-4, and A-5), and alternating beds of well-sorted lapilli (L-3), grain-supported normal-graded lapilli ash (LA-5) and ungraded to inversely-graded lapilli ash (LA-7). 
The predominance of facies LA-5 and L-3 suggest that redeposition grading was occurring throughout deposition of the upper units, likely during intervals where deposition of flood materials waned. During even more quiescent intervals, silt deposition occurred. Intermittent deposits of facies A-3 suggest the gradual waning of flood deposition. The presence of a unit of disorganized lithic-rich lapilli ash (LA-8) suggests there may have been periodic massive influxes of sediment that resulted in rapid deposition. Pockets of well-sorted lapilli (L-3) likely were entrained in facies LA-8 because they were in suspension when rapid deposition occurred.

\section{Terrace 1, Interpretation}

The association of facies in Terrace 1 indicates deposition from a highly concentrated suspension of ash and lapilli. The silt horizons and inverse grading could both arise under waning flow conditions after the bulk of pyroclastic material was moved downglacier. Beds of silt tend to cap sequences of inverse-graded lapilli ash, suggesting a natural sequence of waning flow (represented by the inverse grading) followed by suspension settling. It is possible that the association of facies in the middle and upper deposits represents a later-stage reworking of existing deposits, or clasts in suspension, after large volumes of sediment were moved downglacier. Although strong tractional currents produced most of the bedforms in the middle deposits, the association of facies 
in the upper deposits (LA-5, L-3, and A-3) seems to suggest a decrease in energy, which would be expected as the volume of flood materials decreased.

Clasts within the lower, middle, and upper facies of Terrace 1 tended to be sub-angular to well-rounded, with the majority of sub-angular clasts occurring in fine- to medium grained ash or poorly disorganized units. Sedimentological evidence is unequivocal in that this terrace is resedimented rather than airfall; abundant primary sedimentary structures reflect aqueous deposition of the tephra, derived from the up-glacier of substantial volumes of snow and ice. This terrace is nearly $50 \mathrm{~km}$ away from the source vent, indicating that large volumes of volcaniclastic sediment were transported significant distances downglacier. Low-density pumiceous clasts up to $6 \mathrm{~cm}$ in diameter were incorporated in the terrace deposits, as a result of water saturation (cf. Manville et al. 1998). The presence of silt interlayers within the terrace indicates that deposition of the terrace was not instantaneous.

\section{Terrace 2, Lower Deposits}

The lower deposits of Terrace 2, on the north side of Klutlan Glacier (approximately 25 $\mathrm{km}$ from Mount Churchill), are composed predominantly of thick deposits of ripple 
cross-laminated and horizontally laminated ash (A-2) which alternate with sequences of grain-supported normal-graded lapilli ash (LA-5; Figures 60 and 61). Lithic-rich layers (LA-3) are interspersed throughout the lower deposits, but not to the same extent as seen in Terrace 1.

The predominance of laminated ash (A-2) and normally graded lapilli ash (LA-5) in the lower deposits suggests the presence of a high energy environment with migration of low-relief bedforms. A fairly thick unit of facies L-3 occurs near the top of the lower deposits and may be representative of redeposition grading. The silt ( $\mathrm{S}-1)$ in the lower deposits occurs as laminae and lenses in ripple cross-laminated and horizontally laminated ash (A-2), ungraded to inverse graded lapilli ash (LA-7), and in well-sorted ash (A-3). In one place near the bottom of the terrace deposit, a unit of silt occurs with scattered pumice fragments (up to $2 \mathrm{~mm}$ in diameter) that accentuate the bedding surfaces.

\section{Terrace 2, Middle Deposits}

The middle deposits comprise ripple cross-laminated and horizontally laminated ash (A2), beds of silt (S-1), and ungraded to inversely graded lapilli ash (LA-7; Figures 60 and 61). These sequences seem to represent a natural progression from high energy flow (deposition of facies A-2) to waning flow (represented by sequences of inverse grading) 

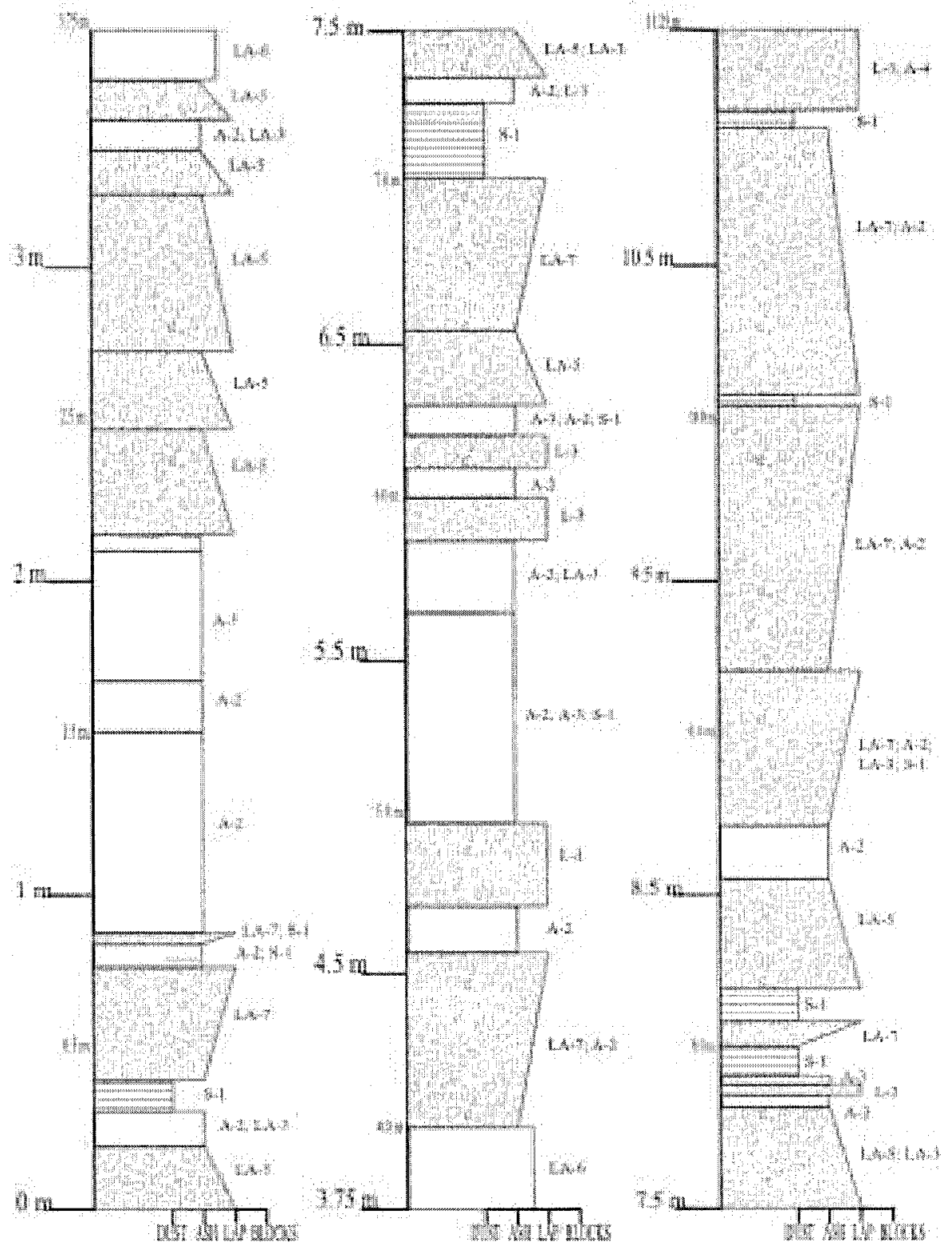

Figure 60: Stratigraphy of the first 11.25 meters of Terrace 2, a 19-meter thick terrace located on the north side of Klutlan Glacier, near the confluence with Gooseneck Glacier, approximately $15.5 \mathrm{~km}$ east of the Yukon-Alaska border and $5 \mathrm{~km}$ east of Mount Churchill. See next page for remaining 8 meters of these terrace deposits. 


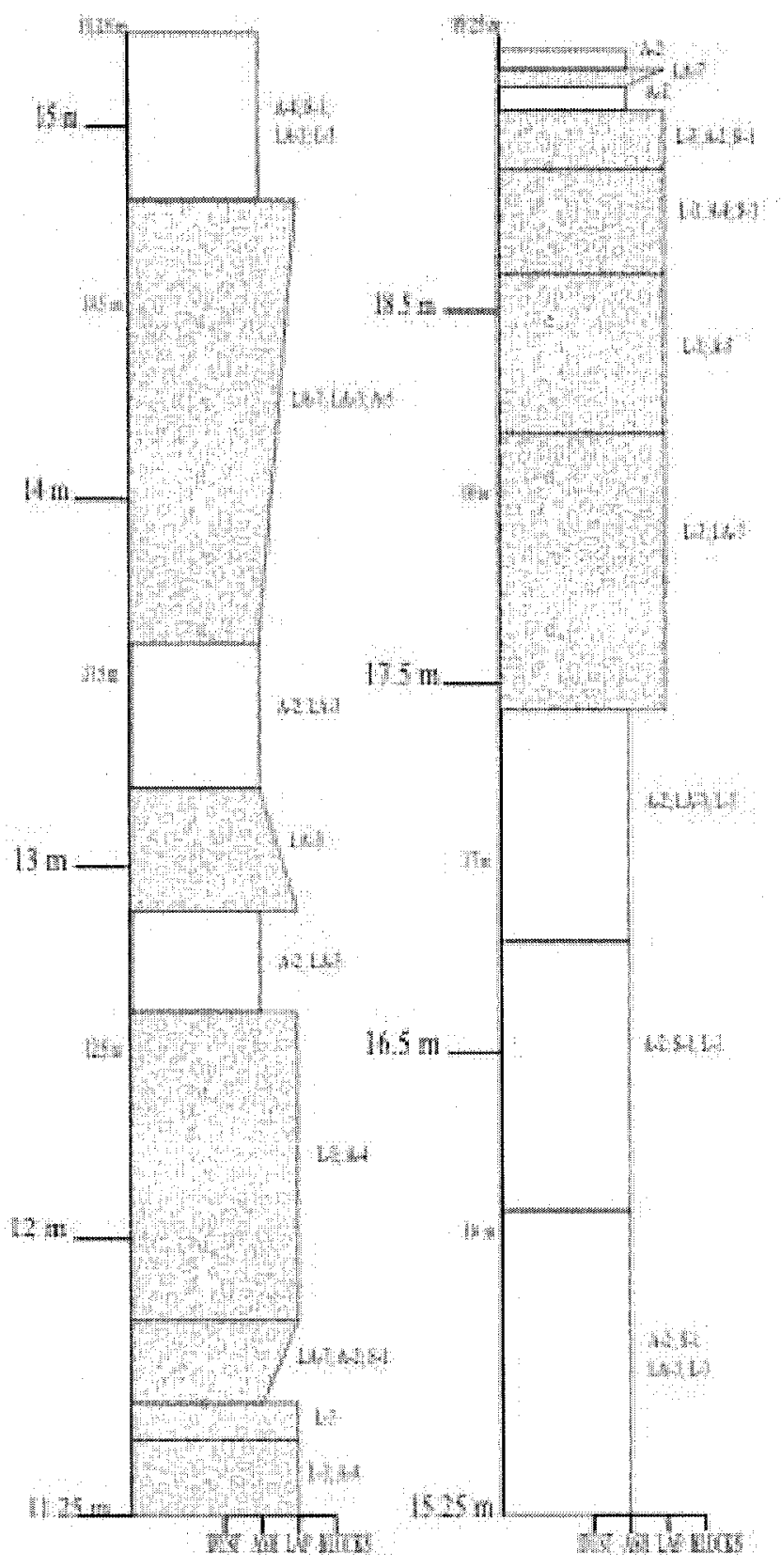

Figure 61: Stratigraphy of the upper 8 meters of Terrace 2, a 19-meter thick terrace located on the north side of Klutlan Glacier, near the confluence with Gooseneck Glacier, approximately $15.5 \mathrm{~km}$ east of the Yukon-Alaska border and $5 \mathrm{~km}$ east of Mount Churchill. Note the predominance of silt in the lower and middle deposits. See previous page for first 11.25 meters of this terrace deposit. 
followed by quiescent periods (suspension settling of clay). A higher proportion of facies S-1 occurs in the lower and middle deposits of Terrace 2, when compared to Terrace 1. A few units of well-sorted lapilli (L-3) occur throughout the middle deposits, suggesting the occasional presence of strong tractional currents and redeposition grading.

\section{Terrace 2, Upper Deposits}

The upper deposits are composed primarily of cross-laminated and horizontal-laminated ash (A-2), lithic-rich ash (LA-3), and well-sorted lapilli (L-3; Figures 60 and 61). Interestingly there is the absence of silt beds or interlayers in the upper deposits. Although one unit of grain-supported, normal-graded lapilli ash (LA-5) occurs at the base of the upper deposits, the rest of the terrace is dominated by thick deposits of laminated ash (A-2) and well-sorted lapilli (L-3). The prevalence of bedforms, normal grading, and the absence of silt interlayers suggests the presence of strong tractional currents in a higher energy environment.

\section{Terrace 2, Interpretation}

Terrace 2 contains a less diverse association of facies than Terrace 1 . Thick units predominate in this terrace, suggesting that transport processes closer to the source vent were more stable than those observed at Terrace 1, near the Yukon-Alaska border. It is clear from sedimentological evidence that this terrace also represents resedimented 
material rather than airfall. However, the predominance of silt in the lower and middle deposits, and its absence in the upper deposits, poses an interesting dilemma. One possibility is that the terrace accumulated in water behind a temporary ice dam. The lower and middle deposits of this terrace reflect deposition in a lower energy environment. Deposition of the upper deposits may have occurred after the ice dam broke, once a new influx of pyroclasts and sediment was brought into the hydrologic system.

\section{Discussion}

The terraces are mainly composed of sub-angular to sub-rounded pumice (ash, lapilli and sub-angular blocks) with lesser amounts of silt, sand, and accessory lithics. Layers within the terraces are moderately to well-sorted with primary structures (cross-beds, normal and reverse graded beds, linguoid ripple marks, and scours) indicative of subaqueous deposition (Donaldson et al. 1996) and fluvial reworking. No primary air-

fall ash layers are evident within the terrace deposits, other than the $1 \mathrm{~m}$ thick layer that caps most of the terraces (Figure 62). The prevalence of pumice in the terraces reflects the nearby eruptive source and high sedimentation rates, as well as an origin distinct from crystal-rich ignimbrite and co-ignimbrite deposits (Walker 1972; Sparks and Walker 1977; Cas and Wright 1987). Characteristic features of ignimbrites and surge deposits, including coarse tail grading, fine-grained basal layers, flow units, levées, channels, and 


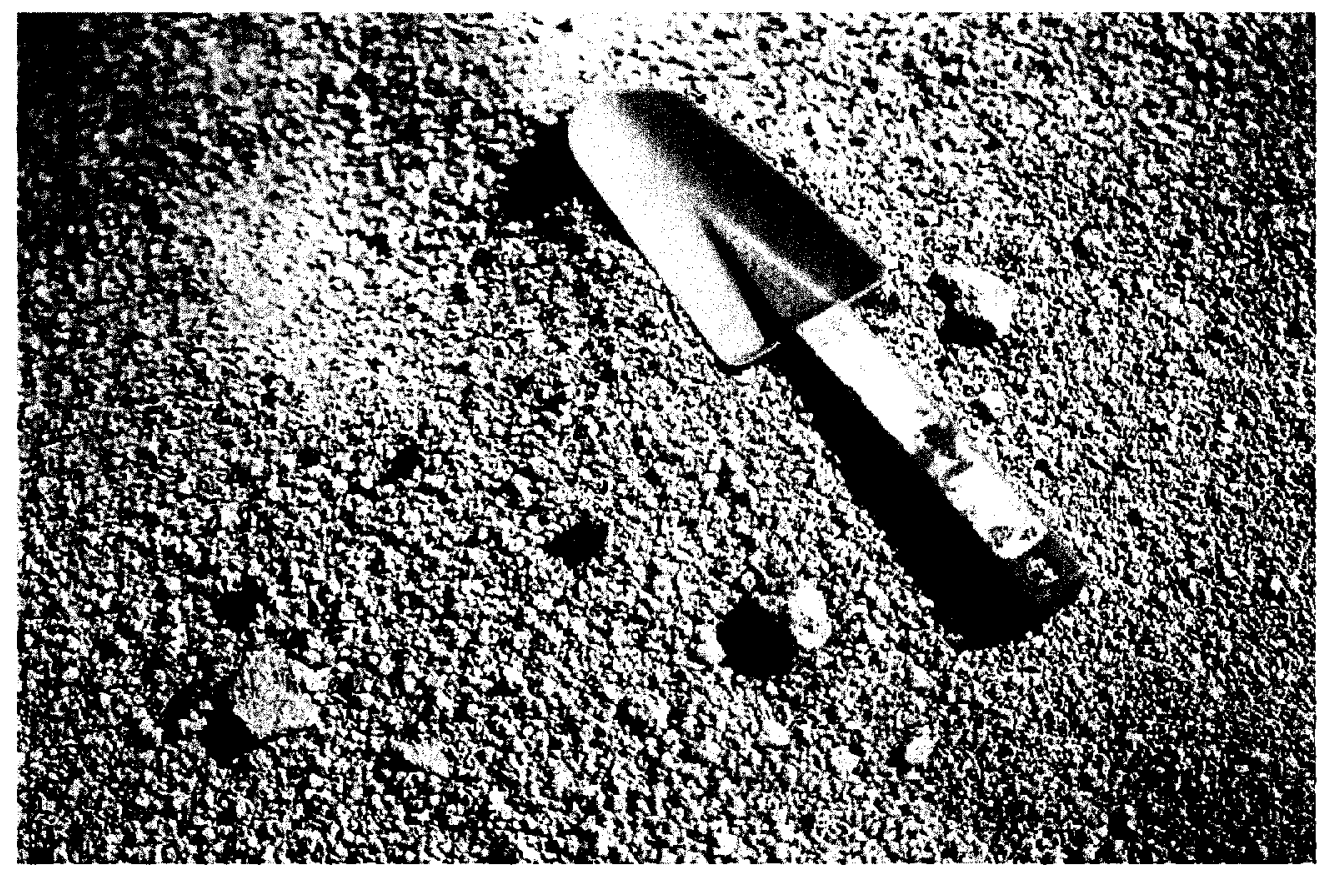

Figure 62: Layers of airfall ash, such as this one, commonly cap terrace deposits. 
steep flow fronts (Cas and Wright 1997) are absent in the terrace deposits. Evidence for hot emplacement (gas segregation pipes, welding, quenched margins, associated devitrification features, columnar jointing, carbonized wood and vegetation (Cas and Wright 1991) is also lacking in the terraces, with the exception of several blocks of pumice near the vent which may have been emplaced as ballistic fragments, due to their pink oxidized color, angularity, and fractures (cf. Lajoie and Stix 1992).

The units from the terraces vary significantly from fallout deposits in several ways: 1) the predominance of moderately to well-sorted sub-angular to sub-rounded pumice; 2) the prevalence of lithic fragments; and 3) the lack of predominantly framework-supported pumice (Lajoie and Stix 1992). Evidence of fluvial deposition in the terrace deposits is provided by the dominance of cross-bedding in many of the facies, and by the presence of small-scale linguoid ripple marks and scours. Variations in facies likely resulted from deposition under fluctuating velocities and energy conditions (Donaldson et al. 1996). The presence of variously sized pumice clasts within the terrace deposits suggests that transport likely involved a combination of processes (cf. Allen and McPhie 2000).

In general, fluviatile detritus is more well-sorted than surge deposits (Guest et al. 1988) which have a much less continuous nature (Guest et al. 1991). Fluvial deposits also have the tendency to form lenses, wash-out features and channel-fills, as well as thin debris 
flows and cross-bedding (Guest et al. 1991), as seen in the terrace deposits. On the other hand, surge deposits tend to be reverse graded with bomb sags (Guest et al. 1988).

It is therefore suggested that proximal terraces were deposited when large volumes of hot volcanic debris melted snow and ice surrounding Mount Churchill and produced hyperconcentrated flood flows. As pyroclastic material was reworked and redistributed, the terraces were built along the margins of Klutlan Glacier, composed primarily of fluvial deposits, with subordinate hyperconcentrated flood flow deposits. The lateral discontinuity of the terraces may be explained by ice blocks that may have jutted up against adjacent valley walls, creating one of more ice dams that could have resulted in temporary lakes. Although general similarities were observed between depositional units, the stratigraphy of each terrace was unique. This suggests that there were local variations in transport processes as well as in depositional environments along the lateral margins of Klutlan Glacier where the terraces accumulated.

Resedimented materials within the terraces likely were deposited from multiple pulses subsequent to the White River ash eruptions. There are no primary airfall units interlayered within the terrace deposits; rather the only airfall occurs as a capping layer up to 1 meter in thickness on most terrace surfaces, and in some places, this layer has been eroded away. There are several scenarios that may be associated with the 
provenance of volcaniclastics in the terrace deposits. First, the ash within the terraces may be east lobe ash, with the capping airfall layer representing a final pulse of volcanic activity after the youngest event. If this is true, the positioning and presence of the airfall layer indicates that reworking of the terraces was either penecontemporaneous with or occurred shortly after eruptive activity. Second, the airfall layer may represent volcaniclastics from the older (north lobe) event with the capping airfall representing the younger White River event. This scenario is supported by the $\mathrm{SiO}_{2}$ composition of the proximal terrace deposits as sampled by Donaldson et al. (1996; Table 2). These values suggest that the terrace material is comparable in chemical composition to the north lobe of White River ash, which displays, on average, a higher $\mathrm{SiO}_{2}$ composition than the east lobe ash. This finding is in agreement with $\mathrm{SiO}_{2}$ values published by Downes (1985) but contradicts the findings published by Jensen and Froese (2007), who suggest that ash from the north lobe, on average, has a lower $\mathrm{SiO}_{2}$ composition than in the east lobe.

An alternative scenario could be that the volcaniclastics represent a mixture of east and north lobe tephra, with the capping airfall unit representative of a final pulse of eruptive activity (associated with the youngest eruptive event). Sedimentological evidence in the terraces supports multiple pulses of activity. During any of these pulses, previously 
resedimented volcaniclastics (e.g. north lobe tephra) could have mixed with younger eruptive material (e.g. east lobe tephra).

Alternatively, the airfall layer may represent a younger unidentified eruptive event. It is entirely possible that the terraces could have formed in years to decades after the eruptions of Mount Churchill. Several ancient eruptions have sustained sediment yields up to 100 times above pre-eruption levels for periods of years to decades after eruptions have occurred (Major et al. 2000). For example, Mount Mazama, c. 6800 years ago, built terraces of primary and reworked materials along the North Umpqua River for a period of a few hundred years as floods entrained and redeposited volcaniclastic material downstream (Freidel 1992). Future geochemical work is necessary to establish a timeline for terrace formation and to distinguish the relative inputs from the two White River eruptions at different stratigraphic levels and in comparison to the capping layer of airfall ash.

\section{Volcaniclastic Fan Facies}

A fan of volcaniclastic sediment occurs at the terminus of Klutlan Glacier (N61 $36.516^{\prime}$, W140 $39.522^{\prime}$; Figure 42). The fan is composed of alternating layers of very coarsegrained sub-rounded clasts of pumice up to $25 \mathrm{~cm}$ in diameter that are inversely graded with bands of lithic-rich layers (Figure 43). Grain size decreases markedly down the 
fan's length; the fan is thickest near the apex and thins laterally across its 190-metre length.

Facies predominant in the volcaniclastic apron include the coarser-grained, inversely graded facies found in the terrace deposits (LA-7, L-3), lithic rich layers (LA-3), and horizontally laminated ash (A-2). Individual clasts are sub-rounded to rounded. Some units contain 30-50\% lithics or are normally graded, others are massive and ungraded, or inversely graded. Beds of silt do not occur with the fan deposits, but cap one of the two studied sequences. It is likely that this volcaniclastic material represents resedimented debris that was carried downglacier by hyperconcentrated flood flows during or subsequent to the Churchill eruptions. The predominance of lapilli-sized material, lack of finer-grained ash, and rounding of clasts suggests that the material was deposited from multiple pulses of mini-hyperconcentrated flows at the terminus of the glacier.

\section{Other Considerations}

Mashiotta et al. (2004) have contended that Mount Churchill is not the source of the White River ash. Their argument is based on the absence of a visible ash layer within a 460-meter long ice core drilled in the col between Mounts Bona and Churchill, and the presence of granodiorite cobbles and boulders on the crater rim. Evidence presented in this dissertation is contrary to their claim, and supports the earlier conclusion that 
Mount Churchill is indeed the source of the White River ash (McGimsey et al. 1990; Richter et al. 1995).

Volcanological evidence for Mount Churchill being the source of the White River ash is supported by the presence of terraces located discontinuously along Klutlan Glacier (sourced in the col between Bona and Churchill) that are formed of White River tephra (Donaldson et al. 1996) and increase in thickness up-glacier towards Bona-Churchill. Stratigraphic and textural data ascertained during this study demonstrate that the terraces are resedimented rather than airfall, requiring that the vast quantities of water needed to deposit the ash must have originated from the melting of snow and ice near the BonaChurchill summit. Such extensive melting is difficult to explain by any process other than the sustained generation of heat during an eruption of Mount Churchill. In addition, lapilli within the Klutlan pumice terraces increase in size and abundance upglacier towards a $2 \mathrm{~km}$-wide amphitheater between Mount Churchill and Mount Bona that opens to the northeast with the morphology reminiscent of a caldera filled with ice. Further evidence is demonstrated by accumulations of White River ash and large lapilli located in a fan deposit at the terminus of Russell Glacier which is also sourced from the Bona-Churchill col, the presence of older $(119 \mathrm{ka})$ dacitic rocks associated with the Churchill edifice located along the caldera rim (Richter et al. 1995), and White River pumice blocks up to $50 \mathrm{~cm}$ in diameter that are present along the caldera rim (personal 
communication, Game McGimsey). Furthermore, when plotted on isopach maps, the axes of the two lobes of White River ash converge near the Churchill depression (McGimsey et al. 1990; Lerbekmo et al. 1975; Lerbekmo et al. 1969; Lerbekmo et al. 1968).

A lack of ash in the drill core sampled from the Bona-Churchill col may be due to postsecondary reworking of ash by ice or wind transport, or simply all the ice and ash has subsequently been moved downslope by post-eruption glacial transport. The surface of Klutlan Glacier presently is clear of White River ash; most if not all ash has been deposited in ice-cored mounds at the toe of the Klutlan (and Russell) glacier. Unfortunately, the arguments presented by Mashiotta et al. do not adequately evaluate the literature pointing to Mount Churchill as the volcanic source of the White River ash (McGimsey et al. 1990) or subsequent work on White River tephra in terraces bordering Klutlan Glacier (West and Donaldson 2002). 


\section{Chapter 5: Potential Hazards from Future Eruptions of Mount Churchill, Alaska}

\section{Introduction}

Mount Churchill, a stratovolcano in the St. Elias Mountains of Alaska $\left(61^{\circ} 25^{\prime} \mathrm{N}, 141^{\circ}\right.$ 70' W; Figure 2), poses one of the greatest natural threats to Canada (Stasiuk et al. 2003), Alaska, and arguably, to North America. This volcano has produced two of the largest ashfalls in North America in historical times (Figure 1) as well as some of the most extensive deposits of fluvially reworked volcaniclastic materials in the world. The tephra layers produced from the eruptions of Mount Churchill, referred to as the White River ash, are widely used as chronostratigraphic layers in Alaska and Yukon to date sediments and soil horizons (Rampton 1971a; Figure 12) and have been identified as far as 1300 $\mathrm{km}$ to the east of Mount Churchill (Robinson 2001). At least $27 \mathrm{~km}^{3}$ of ash (Robinson 2001) was produced by explosive emission to altitudes greater than $30 \mathrm{~km}$ (Downes 1979), yielding a north lobe of ash ca. 1887 years B.P. (Lerbekmo et al. 1975) and an east lobe ca. 1147 years B.P. (Clague et al. 1995; Figure 1). Recent work by Jensen and Froese (2006) suggests that the north lobe was deposited between 150-500 AD (based on dating of floodplain exposures along the Yukon River) and covers $100,000 \mathrm{~km}^{2}$; comparatively the east lobe was deposited at approximately $800 \mathrm{AD}$. and covers 500,000

$\mathrm{km}^{2}$. Both events (VEI=6; Sierbert and Simkin 2002; Table 1) resulted in extensive 
flooding of the Klutlan glacial valley, and produced widespread ecological devastation in Canada and Alaska.

The White River eruptions occurred without the benefit of written records about the extent of their impact on the environment. However, anecdotal evidence referring to disruptions and changes in the aftermath of the youngest eruption of ash (east lobe) persists in the oral traditions of indigneous peoples, attesting to the significance of the last volcanic event over a thousand years ago. Furthermore, comparisons with historical and modern-day eruptions and their effects (e.g. Krakatau 1883; Katmai 1912; Mount St. Helens 1980; Table 1) tell us that the height of the ash clouds (30-35 $\mathrm{km}$; Downes 1979) and the intensity of the east and north lobe eruptions would have been sufficient to warrant significant changes in our global climate. The accumulation of tephra during the eruption of Mount St. Helens in 1980 demonstrated that even thin layers of ash up to $1 \mathrm{~cm}$ thick cause extensive environmental damage, killing crops, vegetation, damaging irrigation systems and polluting rivers and streams. Economic activity is also affected by thin accumulations of ash, which cause power outages and the impedement of motor vehicle traffic, engines, and other machinery. Current evidence suggests that $120 \mathrm{~cm}$ of ash and pumice, enough to collapse roofs, accumulated in regions up to $200 \mathrm{~km}$ from Mount Churchill (Bostock 1952; Robinson 2001). Thousands of years ago, these deposits would have choked drainage systems 
leading away from the volcano, resulting in contamination of food and water, and significantly affecting the people and animals that relied upon these food sources. Several anthropologists believe that the effects from the east lobe ash were detrimental to survival, initiating a series of migrations of the local Athapaskan peoples to the Pacific Coast of British Columbia (Pacific Athapaskan) and to the southwestern United States (Apache and Navajo; Workman 1974; Derry 1975; Workman 1979; Cruikshank 1981; Moodie et al. 1992; Harris 2000).

If an explosive eruption of simlar magnitude to either White River event were to occur today, areas within a $100 \mathrm{~km}(\sim 62$ mile) radius would be inundated with enough ash to collapse buildings and put regional air travel at risk (Figure 64). With reference to current drainage patterns, downstream flooding produced by the melting of snow and ice could be expected to affect major highways, communication lines, wildlife, land, fisheries, and communities in Alaska, Yukon, and northern British Colombia (Figure 64). Despite the multitude of potential volcanic hazards, a risk assessment of Mount Churchill has not been completed. Several factors, including credibility (Mount Churchill has not erupted historically), a lack of accessibility leading to difficulty in studying the previous eruptive deposits, and a remote location away from the major towns and cities in Yukon and Alaska, has increased the tendency to overlook Mount Churchill as a potentially dangerous volcano. A lack of knowledge surrounding 
historical volcanic eruptions in Canada has also contributed to the belief that most Canadians are not at risk from future volcanic eruptions or their associated hazards (Stasiuk et al. 2003). For example, few Canadians are aware of the basaltic eruption in 1775 from Tseax Volcano in the Stikine volcanic belt in northern British Columbia that killed approximately 20,000 Nisga'a indigeneous people (Hickson et al. 2007).

This chapter argues that a detailed hazards assessment is necessary to fully understand the eruptive history of Mount Churchill and to mitigate potential hazards associated with future activity, which may be exacerbated by the interaction of tephra with snow and ice. It therefore describes a range of hazardous phenomena that could be associated with future eruptions of Mount Churchill and the approximate areas most likely to be affected. A comprehensive methodology is presented that combines a quantitative approach (e.g. the magnitude and frequency of large-scale volcanic events from Mount Churchill) with a socially sensitive angle aimed to construct risk assessments and influence hazard reduction or national disaster relief and reponse plans (cf. Chester 1993; Warrick 1979). Because the complex interactions between eruptions, environment, economy, and society are unique in every volcanic region, a pervasive approach to hazard reduction considers why and how risk factors are interconnected and how they vary from region to region (Chester et al. 1999). 


\section{Introduction- A History of Volcanology}

Since the dawn of time, people have risked exposure to volcanic disasters in exchange for a variety of resources, including scenic vistas and harbors, lush fertile soils, and natural resources like obsidian (Warrick 1979), while attempting to explain the mysterious natural forces around them (Chester et al. 2002). The first accounts of volcanic activity are captured primarily in legends, myths, stories, and the arts and portray a deep connection to culture, philosophy, and spiritual beliefs. One of the earliest artifacts depicting an interest in volcanic phenomena is a painting of an erupting volcano (Hasan Dag) c.6000 B.C. in central Turkey (Krafft 1993). Other cultures, including the ancient Greeks, believed that gods and demons inhabited volcanoes; Hephaestus (or Vulcan, according to the Romans), and Cyclops among others, lived deep in the earth and forged the weapons of the Greek gods (Krafft 1993). This theme, linking volcanic and tectonic activity to the actions of gods, goddesses, or demons has been prevalent around the world since the dawn of time. Many cultures sacrificed animals and even humans to appease the volcanic gods and goddesses whom they held responsible for natural disasters.

Volcanoes, or at least the legends and stories about them, have played an important role in ancient history. One legend about a lava flow from Hekla, in Iceland, suggested that activity from the volcano was responsible for the conversion of the Vikings to 
Christianity (Krafft 1993). Even today, volcanoes continue to shape aspects of religion, culture, and society; in Hawaii, leis of flowers still adorn the slopes of Kilauea as gifts to the goddess of fire, Pele, and in Italy, economic and urban development must be considered in light of potential hazards from future eruptions of one of the world's most deadly volcanoes, Mount Vesuvius.

Perhaps the most striking connection between volcanoes and human society is the role that these stories play in warning future generations about potential volcanic dangers. The observations of Pliny the Elder, who described the eruption of Vesuvius in $79 \mathrm{AD}$, provided one of the first recorded accounts describing specific eruptive phenomena and the effects of these phenomena on the cities of Pompeii and Herculaneum (Zarmati 2005). Centuries later, observations from the eruptions of Krakatau (1883) and Mont Pelee (1902) described similar events and related volcanic hazards, including tsunamis (Ball 1902; Lacroix 1904). The devastation produced by these eruptions was significant partly because the areas hit were densely populated at the time, and no preventative measures were taken, partly because the scientific community did not understand the extent or nature of either pyroclastic surges or tsunamis at the time these two eruptions occurred. As a result, the study of volcanoes was catapulted into a full-fledged science, initiating the development of several new volcano observatories, including the Vesuvius Observatory (1845) and the Pelee Observatory (1903). For the next several decades, the 
focus of volcanology became the study of physical processes of volcanoes, specifically, the magnitude and frequency of extreme events (Chester et al. 2002).

It wasn't until after a wave of well-publicized volcanic disasters in the 1980s and early 1990s (e.g. Mount St. Helens, 1980, Nevado del Ruiz, 1985, Pinatubo 1991, Redoubt 1989) that a major focus on volcanic hazards emerged. This new focus was multidisciplinary, concentrating not only on volcanology but also on the interactions between volcanic effusions, derived sediments, and the environment. These studies included assessments of the human and social aspects of eruptions, emphasizing the vulnerability of local residents and the effects of volcanic eruptions on communities, land, and ecosystems, as well as the physical or chemical processes of magma generation. Observations from these disasters led to the recognition that eruptions are the source of multiple hazards that occur not only during eruptive events (e.g. pyroclastic falls, flows, surges) but also years to decades after (mudflows, floods, secondary pyroclastic flows). A grave example of this lesson arose from the Nevado del Ruiz mudflows, which in 1995 killed nearly 30,000 people in and near the community of Armero, Colombia. A growing number of encounters between jet aircraft and volcanic ash (e.g. Galunggung, Indonesia in 1982, Mount Redoubt, Alaska, in 1989 and Mount Pinatubo, Philippines, in 1991; Tilling and Lipman 1993) served to accelerate concerns, spurring on research in aviation volcanic hazards during this time. 
In the last few decades, there has been a growing desire to assess and evaluate volcanic hazards and the vulnerability of people living near active volcanic centers (Chester et al. 2002). The 1990 s were designated by the United Nations as the International Decade for Natural Disaster Reduction (IDNDR), and efforts during this time were concentrated on developing pro-active policies for several high-risk volcanic regions around the world. Proactive approaches to hazard assessment are useful because information about a potentially hazardous volcano should be available before a disaster occurs (Tilling and Lipman 1993), and because evacuations and other protective measures are much more successful if planned prior to, rather than during response to a volcanic crisis (Chester et al. 2002). Each year nearly 500 million people around the globe are exposed to volcanic hazards; proactive planning has therefore become a necessity in many regions (Chester et al. 2002). Awareness is a key factor in mitigating impact; we must be careful not to assume that since a volcano has not erupted in the recent past that it will not erupt again (Neal et al. 2001). The coast of Alaska is a tectonically and volcanologically active region, and many volcanoes within the Aleutian or Wrangell volcanic arcs may be dormant rather than extinct (Miller et al. 1998). Intense monitoring of Mount Pinatubo, which erupted unexpectedly, and for the first time historically in 1991, prevented the loss of 5,000 to 20,000 lives (Newhall et al. 2005). A proactive approach with respect to a similarly hazardous volcano like Mount 
Churchill must therefore be taken, in combination with public education and awareness, in order to successfully minimize any losses that might be associated with future eruptions.

\section{The White River Ash Eruptions}

Mount Churchill, an unmonitored volcano in the St. Elias Mountains of Alaska (Figure 2), has erupted twice in the past 2000 years (McGimsey et al. 1990). These eruptions produced one of the largest tephra-fall deposits $\left(27 \mathrm{~km}^{3}\right.$; Robinson 2001) in the circum-Pacific, preserved in two distinct lobes from volcanic eruptions ca. 1147 (east lobe; Clague et al. 1995) and 1887 years B.P. (Lerbekmo et al. 1975; Figure 1). Ashfall from the eruptions, referred to as the White River ash, is up to $50 \mathrm{~m}$ thick near the summit of Mount Churchill (Richter et al. 1995a) and covers over 500,000 $\mathrm{km}^{2}$ $\left(\sim 336,000 \mathrm{mi}^{2}\right)$ of British Columbia, Yukon and Northwest Territories and Alaska (Robinson 2001; Figure 1). Most ash was distributed by east-blowing winds over the southern Yukon Territory during the much more violent eruption ca. 1147 years B.P. However, on the Volcanic Explosivity Index (VEI), the eruptions of White River ash are both classified with a VEI=6 (Siebert and Sinkin 2002-; Table 1). Eruptions of VEI 6 are significant events, producing on average 39 to $100 \%$ fatalities in proximal regions and occurring only once every 100 to 1,000 years (Siebert and Simkin 2002-). An analysis of fragmentation (F) and dispersal indices (D) also indicates that the 
eruptions of White River ash were violent Plinian-style eruptive events (Downes 1979).

The widespread distribution of ash devastated surrounding areas in Alaska and Yukon for hundreds of kilometers. The head of the White River, nearly $25 \mathrm{~km}$ from Mount Churchill, most likely derives its name from the enormous amount of white ash and pumice that choked drainages subsequent to the eruptions. Even today, small fragments of pumice up to $2 \mathrm{~cm}(\sim 0.8$ inches $)$ in diameter are regularly deposited along the banks of the White River, as far downstream as the Alaska Highway and beyond (Figure 63). The most catastrophic hazards typically result from eruptions of volcanoes like Mount Churchill which are mantled by a substantial cover of snow and ice, e.g. Nevado del Ruiz (1985) and Mount St. Helens (1980; Major and Newhall 1989). Hyperconcentrated flood flows that were initiated when hot volcanic material mobilized snow, ice, and volcanic debris at the summit of the volcano, are inferred to have produced flows that descended through several well-defined glacial valleys emanating from Mount Churchill to form terraces of thick pumice-rich debris, some in excess of 15 metres thick. A 190-metre long fan of volcaniclastic debris from the White River eruptions exists at the terminus of Klutlan Glacier (Figure 8). Based on the extensive nature of these volcaniclastic deposits, it is likely that future eruptions of Mount Churchill will also have widespread and significant effects. 


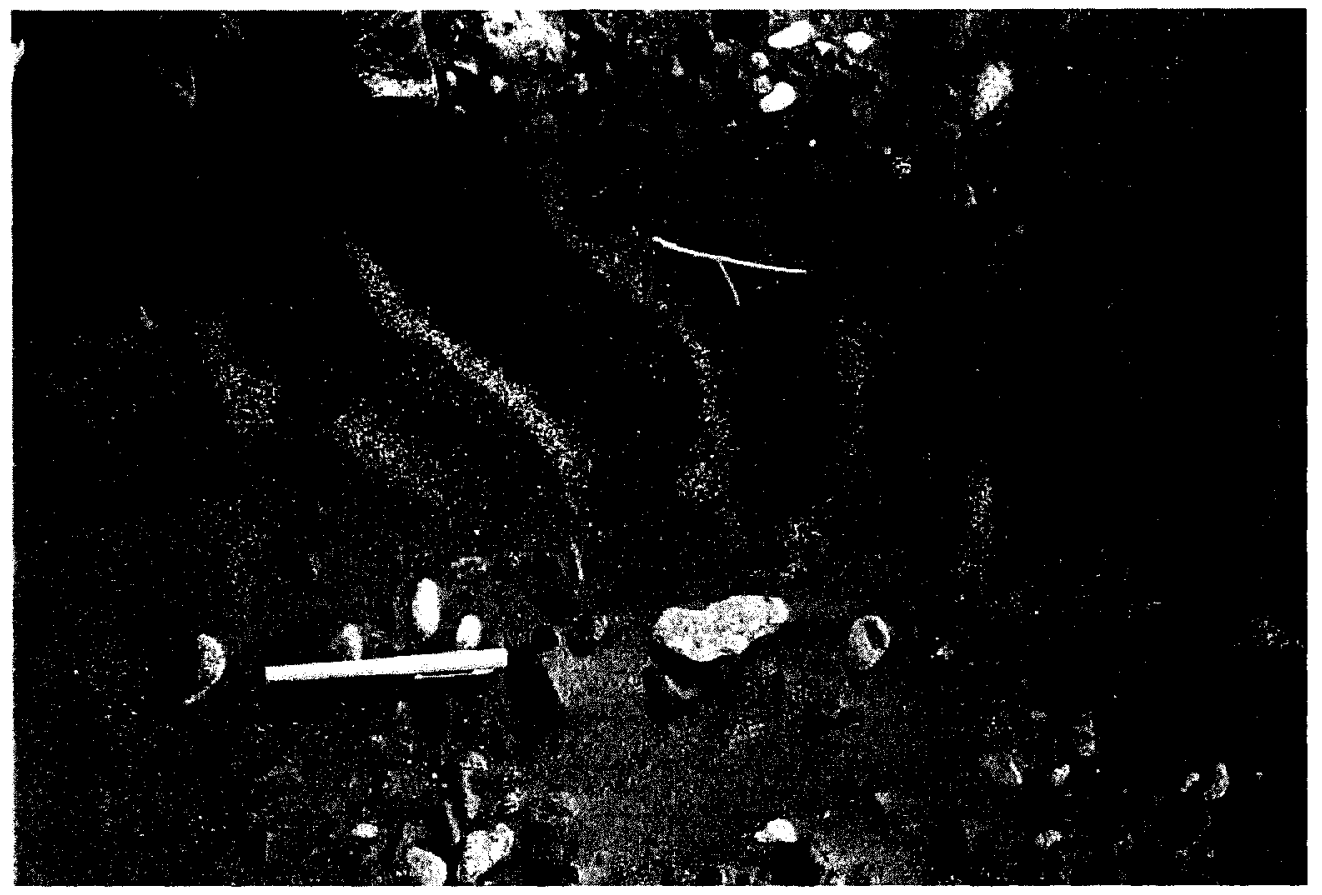

Figure 63: Pumice deposited along the banks of the White River, near the Alaska Highway, north of Beaver Creek, Yukon Territory. 


\section{Geologic Setting}

Mount Churchill belongs to the late Cenozoic, $10,400 \mathrm{~km}^{2}$, Wrangell Volcanic Field (WVF) of southern Alaska (Richter et al. 1990; Figure 10). The field itself belongs to a regional belt of the same name (Wrangell Volcanic Belt; WVB), which extends $500 \mathrm{~km}$ southeast from Alaska and Yukon into north-western British Columbia (Skulski et al. 1991). The WVF comprises eleven major volcanic centres, active from the late Miocene to the present (Richter et al. 1995b; Table 3). Five volcanic fields, including the WVF (26 Ma to present), the St. Clare Creek field (18-10 Ma), Nines Creek field (15.5-13.0 Ma), Alsek field (13.5-10.8 Ma), and Stanley Creek field (Skulski et al. 1991) occur along the coastlines and interior regions of Alaska, the Yukon, and British Columbia. Volcanic rocks within the freld are collectively referred to as the Wrangell Lava (Mendelhall 1905; Miller and Richter 1994). Outcrops range from andesitic to basaltic or rhyolitic subaerial and subglacial lava flows, dacite to rhyolite domes, lahars, cinder cones, dikes, small subvolcanic intrusions, and to a lesser degree, tephra and volcaniclastic deposits (Richter et al. 1990; Miller and Richter 1994; Richter et al. 1995a). Most of the volcanic centres within the field have been constructed over thousands of years from andesitic flows (Hickson 1994); the only widespread silicic plinian eruptions are from Mount Churchill and Mount Drum (Preece 1997).

Tectonic interactions in Alaska and the Wrangell volcanic field are complex. Southern 
Alaska comprises seven composite allochthonous tectonostratigraphic terranes which have accreted to its continental margin over several millions of years (Bruns 1983; Plafker and Berg 1994). The WVF overlies two of these terranes, the Wrangellia terrane, which underlies most of the field, and the Alexander terrane, which underlies a small segment in the southeastern part of the field (Miller and Richter 1994). The Wrangellia terrane comprises sedimentary and boundaries in southern Alaska. The field lies next to the Denali-Chatham volcanic rocks ranging in age from Pennsylvanian to Cretaceous; the Alexander terrane is composed of similarly-aged middle-to-late Paleozoic sedimentary rocks (Miller and Richter 1994). The Wrangellia terrane lies north of the Yakutat terrane, which is currently being accreted to the margin of southern Alaska.

The WVF is bounded by numerous transform fault systems and active plate boundaries, with the Denali-Chatham Strait- Queen Charlotte Islands transform fault system forming the Pacific-North American plate boundary, and the Aleutian megathrust forming a zone of active plate subduction (Richter et al. 1990). A Wrangell-Wadati Benioff zone, which appears to be continuous with the Aleutian Benioff zone, extends to a depth of $100 \mathrm{~km}$, dipping to the northeast beneath the western and most recently active portion of the WVF (Skulski et al. 1991; Stephens et al. 1984; Page et al. 1989). Regional tectonic history of the WVF has been complicated 
further by changing tectonic regimes in southern Alaska during the late Cenozoic. In the past $30 \mathrm{Ma}$, the tectonic setting of this region changed from a subduction to a transform margin between the north-eastern Pacific and North American plates (Skulski et al. 1991).

Volcanism of the WVF from 26 to $0.2 \mathrm{Ma}$ has been attributed to subduction of the Yakutat terrane (coupled to the Pacific oceanic plate) under the continental margin of Alaska (Richter et al. 1990). A general progression of eruptive activity from east to west across the field is apparent (Miller and Richter 1994). In the west end of the field, eruptive products are $1 \mathrm{Ma}$ or younger; in the central area (including Mount Wrangell), ages range from 1-5 Ma, and in the east they range from 8 to $20 \mathrm{Ma}$, with the exception of the eruptions of White River ash 1887 and 1147 years B.P. (Miller and Richter 1994). Several age estimates from the southeastern region of Yukon Territory range from 11 to $25 \mathrm{Ma}$, which suggests that the progression of volcanism increased from about $0.8 \mathrm{~km} / \mathrm{Ma}$ at $25 \mathrm{Ma}$ to more than $20 \mathrm{~km} / \mathrm{Ma}$ during the past 2 Ma. A decrease in Wrangell volcanism over the past few million years has been linked to changes in the rate and angle of Pacific plate convergence and to decoupling of the Yakutat terrane over time (Richter et al. 1990). Further changes in regional plate interactions may therefore impact the style and frequency of Wrangell eruptions. 
The eruptive history of Mount Churchill prior to deposition of the White River deposits ca. 1147 and 1887 years B.P. is not well-known. Evidence of previous volcanic activity from Mount Churchill, if it exists, has likely been eroded away by glacial action or is hidden beneath the perennial snow and ice that caps the volcano's summit. Soft unconsolidated ash and pumice layers (produced from pyroclastic fall, flow, or surge deposits) tend to be poorly preserved in the rock record because they are more vulnerable to erosion and scour by glaciers (Fierstein and Hildreth 2000). Significant deposits of ash, therefore, tend to be preserved in areas beyond reach of the region's erosive glaciers. Fine examples of this type of preservation are the terrace deposits discussed in Chapter 4, approximately $100 \mathrm{~m}$ above the present surface level of Klutlan Glacier.

\section{Preliminary Risk Assessment}

A variety of factors in the Wrangell volcanic region seem to suggest that the area is potentially active; however, a number of signals have never been measured near Mount Churchill (mountain deformation, cracked glacial segments, and melted glacial ponds; Mileti et al. 1991). In absence of the monitoring of these parameters, examples of past volcanic behaviour are often our best clues of future volcanic activity. Most hazard assessments are based on data collected from numerous geological, geochemical, and dating studies which bring together a comprehensive picture of the 
eruptive style and history of a volcano, including the distribution, nature and recurrence interval of previous eruptions and related hazards (Tilling and Lipman 1993). To establish the nature and quantity of future eruptions at Mount Churchill, field work was completed earlier in this study to estabish the nature of past eruptions, magnitudes, ages, stratigraphy, and reconstruction. This work has been crucial in establishing the magnitude and character of the White River eruptive events and has given us an example of what to expect in terms of future volcanic behaviour from Mount Churchill.

Stratigraphic studies have demonstrated that future eruptions from Mount Churchill will have devastating effects because past eruptions involved large volumes of snow and ice, which led to the development of volcanic-debris dams and flooding. Examination of the literature indicates that several of the most catastrophic volcanic events resulted from eruptions of similar volcanoes mantled by a substantial cover of snow and ice (Major and Newhall 1989). Most of the area around Mount Churchill is uninhabited wilderness, but Kluane National Park (Yukon) and Wrangell-St. Elias National Park and Preserve (Alaska) are popular tourist and recreational areas in the summer. In recent years, the summits of Mounts Bona and Churchill have attracted the attention of many avid mountain climbers. 
Future volcanic activity from Mount Churchill could significantly affect the citizens, property, industry and economy in Alaska, Yukon, Northwest Territories, and northern British Columbia. Although Wrangell volcanoes have been relatively quiet in historic times, comparable volcanic centres in the Alaska Peninsula (the Aleutians) have exhibited recent and historic violent outbursts e.g. Augustine Volcano (Lovick 2006; Waythomas and Waitt 1998), Mount Redoubt (Waythomas et al. 1998), Crater Peak, Mount Spurr (Waythomas and Nye 2002), Novarupta (Fierstein and Hildreth 2000), and Mount Wrangell (Richter et al. 1995b). There have been several dormant volcanoes in Alaska (e.g. Novarupta in 1912) that have had no records of historical eruptions until a major explosive eruption has occurred (Wilcox 1959). A current example is Fourpeaked Volcano, whose last major eruption was over 10,000 years ago and is now showing renewed signs of possible eruptive activity (Alaska Volcano Observatory 2007). It is therefore likely that the style, scale, and frequency of volcanism currently being experienced on the Alaskan Peninsula will occur again in the Wrangell region.

In view of this possibility, evaluating and comparing the different styles of volcanism and types of hazards that exist on the Alaska Peninsula might better equip us to assess patterns of behaviour and hazards which may be associated with eruptions of Wrangell volcanoes, and in particular, with future eruptions of Mount Churchill. Because most of the Aleutian and Wrangell volcanoes are mantled with a cover of snow and ice, 
eruptions are often accompanied by significant flooding. For example, hot and cold volcanic avalanches produced from the melting of snow and ice near the eruption site of Mount Drum nearly 100,000 years ago resulted in the deposition of approximately 7 $\mathrm{km}^{3}$ of volcanic material over an area of about $207 \mathrm{~km}^{2}$ (Richter et al. 1995b). Mud and volcanic material from this eruption were carried over $84 \mathrm{~km}$ from Mount Drum down the Copper River valley to the town of Chitina (Richter et al. 1995b). Recent work has suggested that the source of the Chitina lahars may have been Mount Wrangell instead of Mount Drum (Waythomas and Wallace 2002). Lahars were also generated in Drift River subsequent to the 1965-1968 and 1989-90 eruptions of Mount Redoubt (Waythomas et al. 1998) and were associated with the 1992 eruptions of Crater Peak, Mount Spurr (Meyer and Trabant 1995). At least 11 debris avalanches have been associated with eruptions of Augustine Volcano over the past $1800-2000$ years (Siebert and Simkin 2002-).

\section{Potential Impacts of Volcanic Hazards}

Reports from the United States Geological Survey consistently define volcanic hazards as "any volcanic phenomenon that is potentially threatening to life or property, with or without eruptive activity" (Waythomas et al. 1998; Fierstein and Hildreth 2000). The traditional approach in studying volcanoes has largely concentrated on the magnitude and frequency of large-scale volcanic events (Chester 1993). Warrick (1979, p.165, 166) 
makes an important distinction between volcanic events and volcanic hazards when he

says that volcanic hazards arise from an interaction of natural systems with humans:

"First and most important is the fundamental distinction between volcanic events and volcanic hazards. Volcanic hazards arise from an interaction of human use systems and natural event systems (i.e. volcanic processes and products). In and by itself, nature is neutral. This is a simple but often overlooked point. Metaphorically, the cataclysmic eruption of Mount Katmai in 1912 is the towering tree falling in the uninhabited forest- does it make a sound if no one is there to listen? Although nature provides the volcanic event, in the last analysis it is the actions of people that are responsible for the resultant hazards."

The impact of a volcanic eruption on a surrounding population or environment depends on numerous factors, including the location and number of vents, the size, frequency, rate, duration, intensity, style, and history of an eruption or series of eruptions (Fierstein and Hildreth 2000). The hazards produced by an eruption may depend upon the magma composition; as an example, basaltic eruptions tend to produce minimal hazards in comparison to the more highly explosive behaviour posed by high silica to thyolitic eruptions (Stasiuk et al. 2003). Environmental conditions also influence the impact of an eruption (e.g.) the direction and speed of prevailing winds, weather conditions, topography (slope stability) and seasonal timing of eruptions. Furthermore, the impact of potential of secondary or related hazards (tsunamis, floods, etc) should be considered, including the amount of snow and ice that could interact with hot volcanic material, and proximity of the volcanic centre to 
stream drainages, which may become outlets for hyperconcentrated flood flows, lahars, or pyroclastic flows/surges (Fierstein and Hildreth 2000). Economic factors, including the locations of towns, villages, cities, hydrological, industrial, and agricultural resources, and national parks and preserves relative to a volcanic centre must be considered. It is also important to note fluctuations in urban and rural population densities, and the structural integrity of roads and bridges in these areas.

The effects of volcanic hazards also depends upon the distance from the volcanic source. Local hazards (within tens of kilometers of the vent) are typically more intense and numerous than the more far-reaching regional hazards. This is because the energy of most hazardous processes decreases with distance from source (Fierstein and Hildreth 2000). Prior hazard assessments have indicated that whereas tephra falls, atmospheric effects, earthquakes, acid rain and toxic gases tend to be the most pressing volcanic hazards, the relative severity of these hazards varies greatly in different eruption scenarios (e.g. pyroclastic flows and tsunamis often result in more volcano-related deaths) resulting in data that are often subjective and difficult to compare at a regional level (Blong 1984).

Based on previous patterns of eruptive activity, future eruptions of Mount Churchill are likely to produce airborne ash hazards (including tephra-fall deposits and ash 
clouds), pyroclastic flows, surges, or blasts, volcanic-debris dams, hyperconcentrated flood flows and downstream flooding. Other potential hazards include lahar formation and of course, the effects produced by the primary hazards (e.g. aviation hazards, worldwide climate fluctuations, water/food contamination by ashfall). Ashfall from previous eruptions covered at least $500,000 \mathrm{~km}^{2}$ in Canada and Alaska (Figure 1; Robinson 2001). Drainage systems leading away from the source (White River, Generc River) would be affected by increased sediment supply, hyperconcentrated flood flows, and downstream flooding (Figure 64).

\section{An Eruption Scenario}

Mount Churchill is presently considered to be a low-risk volcanic threat by most politicians and the general public because it is relatively remote from infrastructure and communities; however, based on previous activity, it presents one of the greatest hazards of any volcano in Canada (Stasiuk et al. 2003). Highly explosive eruptions of the same magnitude as the White River events have had significant local, regional, and global impact in other regions in the past. Therefore, although it is useful to evaluate previous eruptive events, it is also important to develop local emergency plans, and to assess the types of hazards that might be associated with future eruptions (Table 5), given the types of communities and infrastructures present in vulnerable areas today. In this assessment, a worst case scenario is developed in which tephra fall is dispersed 


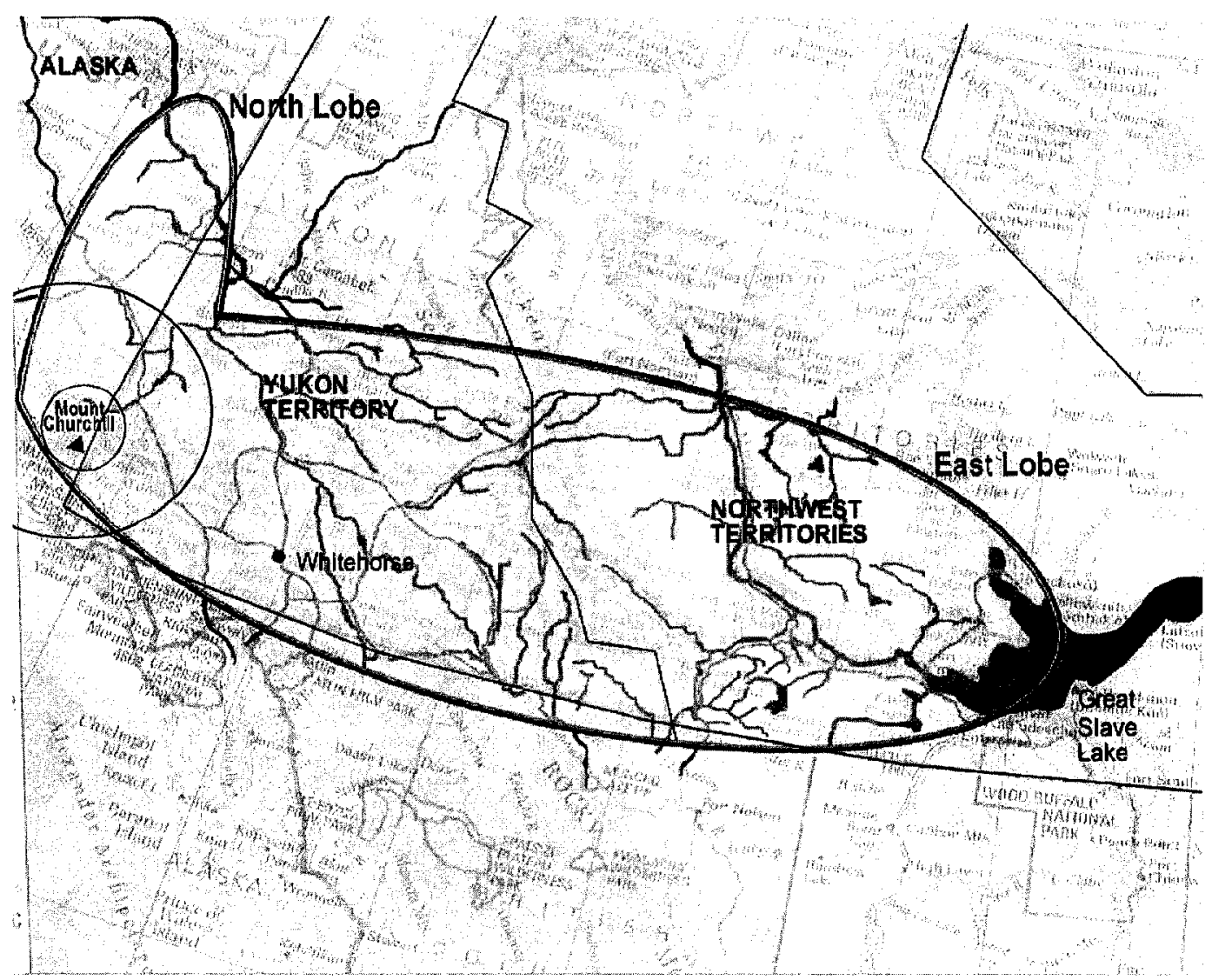

Figure 64: Hazard map depicting areas that would be affected by volcanic hazards during future eruptions of Mount Churchill. Areas marked in blue would potentially be affected by increased sediment supply and downstream flooding, particularly near the source vent; areas in red mark roadways and areas that would be affected by tephra accumulations between $5-15 \mathrm{~cm}$; and areas in orange may be affected by pyroclastic flows or surges. This hazard map is based on previous eruptive activity; areas affected by future activity will vary drastically depending on the size, scale, and nature of future explosive eruptions. 


\begin{tabular}{|c|c|c|c|}
\hline Type of hazard & $\begin{array}{c}\text { Proximal }(<50 \mathrm{~km} \\
\text { of the volcano })\end{array}$ & $\begin{array}{c}\text { Distal }(>50 \mathrm{~km} \text { of } \\
\text { the volcano) }\end{array}$ & Airborne \\
\hline Tephra fall & $\begin{array}{l}\text { Yes } \\
\text { bigh }\end{array}$ & $\begin{array}{c}\text { Yes } \\
\text { bigh to moderate }\end{array}$ & $\begin{array}{l}\text { Yes } \\
\text { bigh }\end{array}$ \\
\hline Ash clouds & $\begin{array}{l}\text { Yes } \\
\text { high }\end{array}$ & $\begin{array}{l}\text { Yes } \\
\text { high }\end{array}$ & $\begin{array}{l}\text { Yes } \\
\text { High }\end{array}$ \\
\hline $\begin{array}{l}\text { Lahars, floods, and } \\
\text { volcanic debris dams }\end{array}$ & $\begin{array}{l}\text { Yes } \\
\text { bigh }\end{array}$ & $\begin{array}{c}\text { Yes } \\
\text { moderate }\end{array}$ & None \\
\hline $\begin{array}{c}\text { Pyroclastic flows and } \\
\text { surges }\end{array}$ & $\begin{array}{c}\text { Possible } \\
\text { bigh }\end{array}$ & $\begin{array}{l}\text { Possible } \\
\text { moderate }\end{array}$ & $\begin{array}{c}\text { Possible } \\
\text { Lowy }\end{array}$ \\
\hline Ballistics & $\begin{array}{l}\text { Yes } \\
\text { high }\end{array}$ & $\begin{array}{l}\text { Unlikely } \\
\text { low }\end{array}$ & $\begin{array}{l}\text { Yes } \\
\text { bigh }\end{array}$ \\
\hline Lava flows & $\begin{array}{l}\text { Possible } \\
\text { low }\end{array}$ & $\begin{array}{c}\text { Unlikely } \\
\text { low }\end{array}$ & None \\
\hline
\end{tabular}

Table 5: Major potential hazards associated with future eruptions of Mount Churchill. Modeled after Waythomas, Miller, and Mangan (2003). 
over populated regions in Canada. This case study is based upon events that occurred during the previous White River eruptions ca. 1147 years B.P., and illustrates how modern communities would be affected by future eruptions of a similar scale.

Based on patterns of previously similar eruptive activity, it is likely that significant precursors would occur around Mount Churchill for weeks or months prior to an eruption. In the beginning eruptive phases, small explosive eruptions might occur, producing ash plumes, and hot tephra which would melt snow and ice in the summit area of the volcano. Hyperconcentrated flood flows would potentially develop, depending upon the rate and amount of snow and ice melt. During later phases of the eruptive cycle, ash falls probably would intensify; during the main phases of the eruption, tephra falls would be significant and would impact a large area across Yukon, Alaska, and Northwest Territories, and the northern part of British Columbia.

\section{Tephra Fall}

Volcanic ash, fragments of pumice, lava, ash, or rock blasted into the air via explosive activity (Fisher and Schmincke 1984; Shipley and Sarna-Wojcicki 1983), is the most significant hazard associated with future large-magnitude events from Mount Churchill. These fragments may be carried several kilometers into the atmosphere by convection, and depending on a variety of factors including grain size, amount of 
material erupted, wind speed and prevailing winds, may fall in areas up to hundreds of kilometers from the source vent. The tephra fall from earlier White River eruptions covered at least $540,000 \mathrm{~km}^{2}$ in Canada and Alaska (Figure 1); this figure has likely been underestimated due to erosion of fine-grained ash farther away from the volcanic source (Robinson 2001). Eruptive cloud heights for the two White River eruptions probably were between 30-35 km (Downes 1979); in comparison, the eruptions of Mount St. Helen's (U.S.A.) in 1980 (VEI =5) and Mount Pinatubo (Philippines) in 1991 (VEI =6; Siebert and Simkin 2002-) produced tephra that rose respectively approximately $19 \mathrm{~km}$ and $35 \mathrm{~km}$ into the air (Newhall and Punongbayan 1996; Tilling et al. 1990). Widespread ash distribution is typical for magmas like these of silicic composition; basaltic eruptions tend to be less explosive in nature. Volcanic ash from previous White River eruptions was composed of angular pumice, glass shards, and rock fragments which ranged in size from ash $(<2 \mathrm{~mm})$ through lapilli $(2-64 \mathrm{~mm})$ to blocks (>64 mm) (Waythomas et al. 1998).

The distribution of tephra fallout from Mount Churchill will vary by several orders of magnitude, depending on intensity of future eruptions (i.e. amount of material deposited, grain size and fall velocity of particles, and the prevailing wind speed, velocity, and direction). In general, tephra layers tend to decrease in thickness and 
particle size with increasing distance from the source. Within $100 \mathrm{~km}$ of Mount Churchill, deposits of White River blocks, lapilli, and ash are up to $1 \mathrm{~m}$ thick (Richter et al. 1995a); beyond this area the average particle size is sand- or silt-size, with thicknesses up to a few $\mathrm{cm}$. It is expected that eruptions of similar magnitude will produce eruptive material of similar distribution range and thickness, although differences in wind speed, velocity, and direction may influence the areas that are affected.

Based on plume projections from the previous White River eruptions, the ash fallout hazard zone would be concentrated in eastern Alaska and southern Yukon Territory, and would include portions of the Northwest Territories and British Columbia (Figure 64). These projections are based on isopach maps from the two previous eruptions of Mount Churchill (Bostock 1952; Robinson 2001), and take into account the probability that future eruptions from Mount Churchill will occur with thicknesses at the specified distances and the the probability that the winds will be blowing in similar directions as they did in the past. It is nearly impossible to accurately predict the volume and aerial extent of the tephra because distribution of the deposit is dependent on so many variables. However, we can predict that the areas most likely to receive ashfall because wind direction and speed will control the movement of the ash cloud (cf. Waythomas et al. 1998). In the Churchill region, prevailing winds are from the 
west and south; thus, areas east and north of the volcano are most susceptible to ash fallout. Unfortunately, the areas east of the volcano are the most highly developed and populated regions in the Yukon Territory.

Accumulations of ash could impact areas within $1300 \mathrm{~km}$ of the vent (Robinson 2001); areas less than $100 \mathrm{~km}$ away from Mount Churchill would be ecologically devastated. The fallout would likely continue over a period of days to weeks to months. Previously, eruptions of White River ash deposited more than $2.54 \mathrm{~cm}$ (1 inch) of ash (Lerbekmo et al. 1975) in Whitehorse (east lobe) and Dawson City, Yukon (north lobe). Ash fall from the east lobe eruption is $0.6 \mathrm{~m}$ or $2 \mathrm{ft}$ thick along the highway outside of Koidern, Yukon Territory, approximately 88 kilometers west of Mount Churchill (Figure 13). Accumulations of $5-15 \mathrm{~cm}$ (2-6 inches) are likely to occur in communities located closer to the source vent (Lerbekmo et al. 1975); in these areas, $10 \mathrm{~cm}$ of ash or more may collapse buildings (Waitt, Mastin, and Begét 1995; Blong 1984), shut down communications, and disrupt civic transportation. The communities that would be particularly vulnerable (based on previous patterns of ash fallout) include Whitehorse (population of 23,272), Beaver Creek (population of 120), Haines Junction (population of 817), Burwash I Landing (population of 89), Destruction Bay (population of 59), and Dawson City (population of 1,826) in Yukon (Statistics Canada 2005; Tables 6 and 7). The towns of McCarthy, Kennicott, Copper City, Glennallen, and Tok in Alaska as well 


\begin{tabular}{|c|c|c|c|c|c|c|}
\hline & $\begin{array}{l}\text { Census } \\
2000\end{array}$ & June 2005 & $\begin{array}{l}\text { December } \\
2004\end{array}$ & $\begin{array}{l}\text { June } \\
2004\end{array}$ & & $\begin{array}{l}\text { Census } \\
2000\end{array}$ \\
\hline & & & & & $\begin{array}{l}\text { Alaska Population } \\
\text { Total }\end{array}$ & $\begin{array}{l}626,932 \\
326,172\end{array}$ \\
\hline $\begin{array}{l}\text { Yukon } \\
\text { Population Total }\end{array}$ & & 31,222 & 31,127 & 30,469 & Alcan Border & 21 \\
\hline Beaver Creek & & 120 & 125 & 109 & Anchorage & 260,283 \\
\hline $\begin{array}{l}\text { Burwash } \\
\text { Landing }\end{array}$ & & 89 & 80 & 78 & Anderson City & 367 \\
\hline Carcross & & 444 & 442 & 419 & Big Delta & 749 \\
\hline Carmacks & & 378 & 392 & 391 & Cantwell & 222 \\
\hline Dawson City & & 1,826 & 1,811 & 1,800 & Chenega & 86 \\
\hline Destruction Bay & & 59 & 56 & 56 & Chicken & 17 \\
\hline Faro & & 381 & 363 & 360 & Chisana & 0 \\
\hline Haines Junction & & 817 & 789 & 772 & Chistochina & 93 \\
\hline Mayo & & 336 & 326 & 302 & Chitina & 123 \\
\hline Old Crow & & 259 & 264 & 263 & Copper Center & 362 \\
\hline Pelly Crossing & & 281 & 279 & 269 & Copperville & 179 \\
\hline Ross River & & 345 & 345 & 327 & Cordova & 2,454 \\
\hline Tagish & & 187 & 184 & 183 & Delta Junction & 840 \\
\hline Teslin & & 417 & 419 & 411 & Deltana & 1,570 \\
\hline Watson Lake & & 1,522 & 1,547 & 1,553 & Dot Lake & 19 \\
\hline Whitehorse & & 23,272 & 23,205 & 22,673 & Dot Lake Village & 38 \\
\hline \multirow[t]{16}{*}{ Other } & & 111 & 114 & 115 & Dry Creek & 128 \\
\hline & & & & & Eagle City & 129 \\
\hline & & & & & Eagle Village & 68 \\
\hline & & & & & Eielson & 5,400 \\
\hline & & & & & Ester & 1,680 \\
\hline & & & & & Fairbanks & 30,224 \\
\hline & & & & & Ferry & 29 \\
\hline & & & & & Fort Greely & 461 \\
\hline & & & & & Fox & 300 \\
\hline & & & & & Gakona & 215 \\
\hline & & & & & Glennallen & 554 \\
\hline & & & & & Gulkana & 88 \\
\hline & & & & & $\begin{array}{l}\text { Harding-Birch } \\
\text { Lakes }\end{array}$ & 216 \\
\hline & & & & & Healy & 1,000 \\
\hline & & & & & Healy Lake & 37 \\
\hline & & & & & Kake City & 710 \\
\hline
\end{tabular}

Table 6: The most current population statistics available for the Yukon Territory (Canada) and the state of Alaska (United States of America). Compiled from data from the Yukon Government Bureau of Statistics $(2001,2006)$ and the United States Census 2000. 


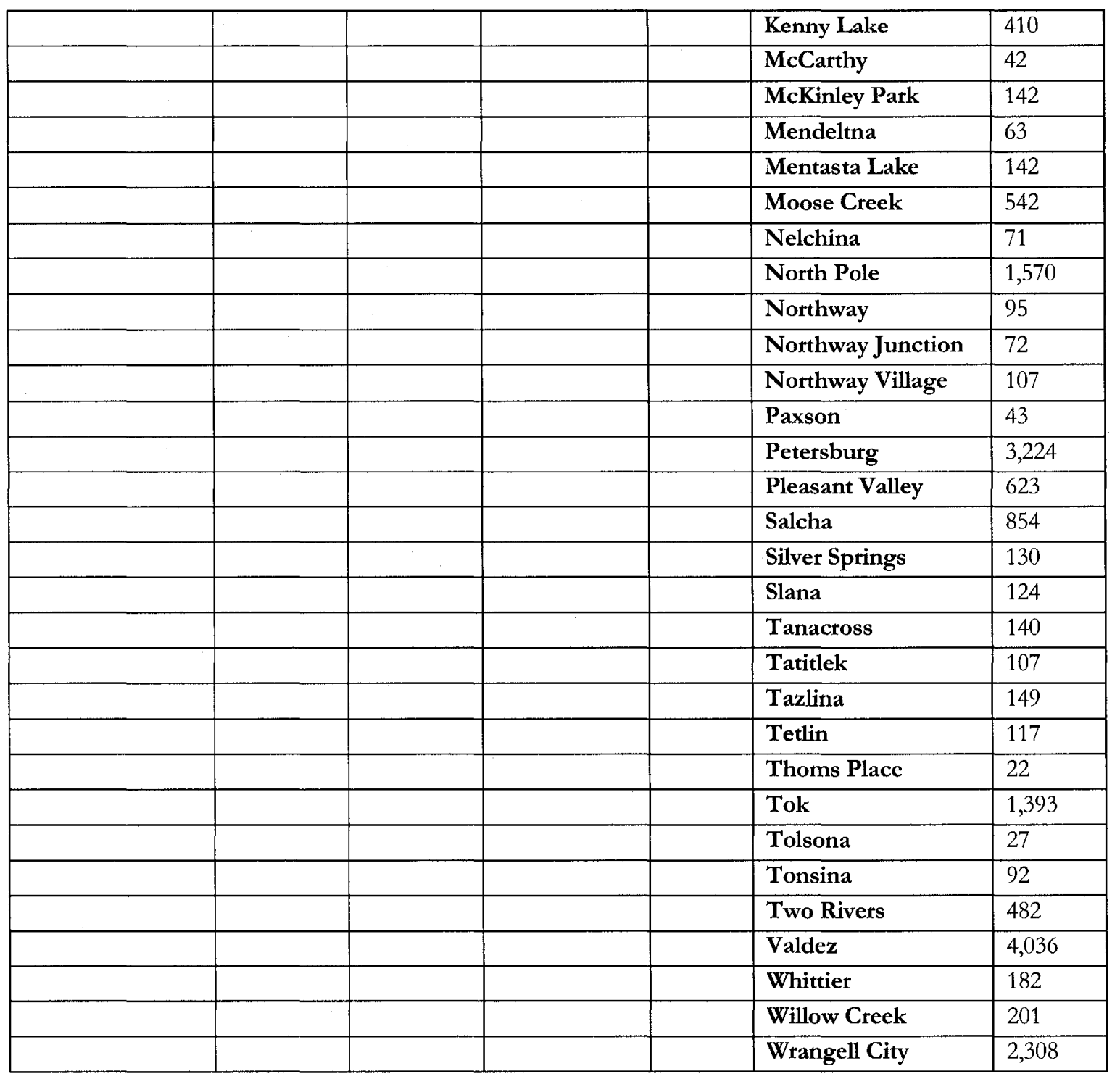

Table 6 continued: The most current population statistics available for the Yukon Territory (Canada) and the state of Alaska (United States of America). Compiled from data from the Yukon Government Bureau of Statistics $(2001,2006)$ and the United States Census 2000. 


\begin{tabular}{|l|l|}
\hline $\begin{array}{l}\text { Communities at Risk from Volcanic } \\
\text { Hazards }\end{array}$ & Population \\
\hline Whitehorse, Yukon Territory & 23,272 \\
\hline Burwash Landing, Yukon Territory & 889 \\
\hline Haines Junction, Yukon Territory & 817 \\
\hline Carmacks, Yukon Territory & 378 \\
\hline Pelly Crossing, Yukon Territory & 281 \\
\hline Beaver Creek, Yukon Territory & 120 \\
\hline Destruction Bay, Yukon Territory & 59 \\
\hline Anchorage, Alaska & 260,263 \\
\hline Valdez, Alaska & 4,036 \\
\hline Cordova, Alaska & 2,454 \\
\hline Tok, Alaska & 1,393 \\
\hline Glennallen, Alaska & 554 \\
\hline Copper Centre, Alaska & 362 \\
\hline McCarthy, Alaska & 42 \\
\hline Chitina, Alaska & 123 \\
\hline Kenny Lake, Alaska & 410 \\
\hline Total population affected: & $\mathbf{2 9 5 , 4 5 3}$ \\
\hline
\end{tabular}

Table 7: Communities most at risk from airfall, lahars, or other volcanic hazards that may be produced from future eruptions of Mount Churchill. Population data from the United States Census Bureau (2000). 
as Fairbanks, Alaska (Tables 6 and 7; United States Census Bureau 2000) could be affected if prevailing wind directions shift during future eruptions. Tephra fallout would impact international, regional, and local airports through the production of airborne ash hazards. Thick accumulations of ash would affect pristine ecological habitats in Kluane National Park and Reserve and Wrangell St. Elias National Park and Preserve, as well as surrounding wildlife reserves. Communities subject to substantial accumulations of ash would be affected by diminished visibility (even during mid-day) and possibly, strikes of lightning that could accompany clouds of falling ash or tephra (Workman 1974). These conditions would impair the ability of humans to travel out of the region, which could result in further psychological stress and panic (Blong 1984). Another grave concern is the possibility of hot ash setting fire to boreal forests at lower altitudes in the region (Waitt et al. 1995). Fires would not only impede escape from the region, but would devastate endemic species of flora and fauna, particularly in a region like Wrangell-St. Elias National Park and Preserve which has been noted for its extensive array of habitats, and endangered wildlife and plants.

Tephra accumulations of $5-15 \mathrm{~cm}$ ( 2 to 6 inches) or more within $100 \mathrm{~km}$ of the vent would pose significant difficulties for communities, power lines, buildings, and roadways (Figure 64). Ash accumulations in this area would certainly destroy electrical equipment (computers, cell phones, cameras, telephones, TVs, etc.) while disrupting 
power, radio, and satellite communications (Stasiuk et al. 2003; Neal et al. 2001). Fine tephra could also cause short-circuiting in electrical systems leading to widespread fires in urban areas (Blong 1984). In addition, thick accumulations of ash in urban regions would obstruct storm sewer, irrigation, and sanitary sewer systems (Waitt, Mastin and Begét 1995; Waitt et al. 1995). Airports and highways would be closed for days due to substantial accumulations of tephra on roads and in the atmosphere. For example, ash only $1 \mathrm{~cm}$ thick impedes the movement of most motor vehicles (Schuster 1981; Warrick et al. 1981) which would render transport out of this area nearly impossible. Mechanical equipment such as power generators, turbines, and vehicles would be susceptible to abrasion, corrosion, and increased wear from the ash (Schuster, 1981, 1983; Shipley and Sarna-Wojcicki, 1983; Waitt et al. 1995). Wet ash also makes roads very slick (Waythomas and Nye 2002). The air, thick with tephra, would be difficult to breathe (Waythomas et al. 1998; Neal et al. 2001), and a mud rain may result if airborne ash mixes with falling rain or snow (Waythomas and Nye 2002).

Tephra accumulations greater than $10 \mathrm{~cm}$ are associated with a threshold above which structural damage in buildings tends to occur (Waitt, Mastin, and Begét 1995; Blong 1984). Building collapse depends on a variety of factors, including roof configuration and construction, workmanship, the weight of the tephra (wet vs dry), and wind drifting, which can result in asymmetrical or imbalanced loads of tephra (Waitt, 
Mastin, and Begét 1995; Blong 1984). Wet tephra is much heavier than dry tephra, and thus is much more likely to cause roof failure (Waitt et al. 1995). Eruptions accompanied by rain in summer or snow in winter (see Chapter 2 for related discussion) therefore pose a greater hazard than those not associated with precipitation. Ceiling collapse typically occurs when thick accumulations of ash drift against walls or foundations, or when ash overloads chimneys, parapets, or ventilation gaps (Blong 1984).

Of course, the magnitude of hazard from ash fallout varies according to the distance from the volcanic source. The chief hazards within $10-30 \mathrm{~km}$ of Mount Churchill include large, falling projectiles (Blong 1984; Waythomas and Nye 2002; Figure 64). Ballistic projectiles from the eruption of Mount Spurr in 1992 were $2-8 \mathrm{~cm}(0.78-3$ inches) in diameter and fell between 2-4 km (1-2.5 miles) from the vent (Waythomas and Nye 2002). Projectiles up to $10 \mathrm{~cm}$ in size also fell $40 \mathrm{~km}$ downwind of Redoubt volcano in 1989-90 (Waythomas et al. 1998). Large blocks thrown from the vent may be faster than the bullet of a typical firearm (Waythomas and Nye 2002) with velocities in the range of 150 to 840 meters per second and temperatures of over 1000 degrees Celsius (1800 degrees Farenheit; Waitt et al. 1995). Luckily, most of the area within 10$30 \mathrm{~km}$ of Mount Churchill is sparsely populated. Communities in close proximity include the fishing communities and camps along the Chitina River, which may be as 
close as $40 \mathrm{~km}$ from the volcano, and the community of McCarthy nearly $70 \mathrm{~km}$ away, whose population fluctuates from fewer than 50 in winter to more than 200 during the summer tourist season; McGimsey et al. 1995; Table 6).

Even small amounts of ashfall have the potential to disrupt social and economic activity across much of Alaska, Yukon Territory, and Northwest Territories, based on previous patterns of activity (Robinson 2001). Ash layers less than $5 \mathrm{~mm}$ thick, deposited in 1992 during the eruption of Crater Peak (Mount Spurr) affected the daily activities of many Alaskan residents (Waythomas and Nye 2002) as did fallout from the eruption of Mount St. Helens in 1980 (Waitt et al. 1995). Fine ash can severely impact human health; particles are highly irritating to the throat and eyes, and if inhaled, may cause or aggravate respiratory conditions (Waythomas et al. 1998; Neal et al. 2001). Air quality and clean up can be significantly diminished for several days or weeks after a volcanic eruption, particularly when vehicular traffic and winds cause dry particles of ash to linger and be periodically resuspended in the air (Waythomas and Nye 2002; Neal et al. 2001). Air travel would be unsafe for days to weeks after the eruption because resuspension of ash would be invisible to pilots and aircraft equipment (Waitt, Mastin, and Begét 1995). Tephra contaminates surface water via toxic or acidic sublimates and condensates which adhere to the ash particles (Waitt, Mastin, and Begét, 1995) and even in small dosages can clog the tiny gills of most fish, 
resulting in death by suffocation. This temporary loss of food, resources, water, and habitat often produces a domino effect that directly impacts animals higher in the food chain, leading to starvation and increased rates of sickness and disease. Thin layers of tephra can also impact hydrological, agricultural, and industrial resources, as demonstrated by the 1980 eruption of Mount St. Helens (Waitt et al. 1995).

\section{Aviation and Air Travel Concerns}

Perhaps the greatest hazard associated with ashfall concerns aircraft which come into contact with airborne ash (McGimsey et al. 1995). Airborne ash is extremely dangerous because it is too dilute to be seen in the air leading to the ingestion of ash or corrosive acid aerosols which shuts down navigational equipment or engines, damages aircraft electronics and equipment, and abrades the leading edges of wings, windscreen, and other surfaces (Fierstein and Hildreth 2001; Stasiuk et al. 2003). Ash clouds are difficult to distinguish from regular meteorological clouds; therefore they are often not detected by the weather radar aboard aircraft (Casadevall et al. 1996). Resuspension of ash particles in the atmosphere is a long-term hazard, causing air travel downwind of the source volcano to be unsafe for days to weeks after the eruption occurs (Casadevall 1994; Waythomas and Nye 2002). The proximity of Mount Churchill to one of Alaska's largest metropolitan centers (Anchorage, Alaska) coupled with its high altitude $(4,766 \mathrm{~m})$ means that even a small eruption would affect 
air travel in the region (McGimsey et al. 1995). Previous eruptions from Mount Churchill injected enormous clouds of ash to probable altitudes between $30-35 \mathrm{~km}$ (Downes 1979).

Even if encounters do not occur between ash clouds and aircraft, air traffic can still be distupted for long periods of time (Waythomas and Nye 2002). The eruption of Crater Peak in 1992 produced ash clouds that extended 13-15 km (8-9 feet) which drifted in several directions and were tracked by satellite for thousands of kilometers beyond the volcanic source (Schneider et al. 1995; Waythomas and Nye 2002). Furthermore, heating of deposits of volcaniclastic material near the vent may produce steam clouds even after an eruption is over, as in the case of Mount Pinatubo which produced ash clouds up to $18 \mathrm{~km}(60,000 \mathrm{feet})$ from steam explosions after an eruption in 1991 (Casadevall et al. 1996).

\section{Lahars and Flooding}

Lahars and hyperconcentrated flood flows are serious volcanic hazards at the BonaChurchill col, which has produced several hyperconcentrated flood flows during past eruptive activity (Chapter 4). Lahars are produced when hot volcaniclastic debris, produced from fallout, or more commonly pyroclastic flows and surges, melt snow 
and glacial ice, resulting in slurries of water and volcaniclastic debris that travel farther than any other hazardous phenomena except airfall tephra (Waitt et al. 1995). In the Mount Churchill region, hyperconcentrated flood flows are dilute mixtures of volcaniclastic material that have mixed with large volumes of water, melted snow, or ice on the volcano's slopes. Jokulhaups, common in Iceland when volcanoes erupt under glaciers, producing a glacial burst due to the melting of ice, are an additional concern, though none have been observed in the Alaska region. The Bona-Churchill col harbours several valley glaciers and permanent snowfields, including the Klutan and Russell Glaciers, which flow northward from Mount Churchill, and the Hawkins and Barnard Glaciers, which flow southward from Mount Churchill (Figure 64). The summit altitude of Mount Bona (5,005 m; 16,421 ft) is slightly higher than Mount Churchill at 4,766 $\mathrm{m}$ (Richter et al. 1995b). The 2-km-diameter vent, on the east side of Mount Churchill, opens to the northeast, is ice-filled, and reminiscent of a possible caldera structure (McGimsey et al. 1990).

The volume of snow and ice on the summit is estimated to be $5 \mathrm{~km}^{3}$ (Richter et al. 1995a). Isolated ice-free areas do occur in topographically higher regions on the southeastern rim of the vent (McGimsey et al. 1990); however, during most of the year, the summit is covered with snow and ice. Because most of this snow and ice is in direct contact with the vent, future eruptions could cause the melting of significant 
amounts of ice and snow that would lead to the formation of volcanic debris-flows, lahars, natural dams, or flooding (cf. Waythomas and Nye 2002). During the eruptions of White River ash ca. 1147 and 1887 years B.P., volcaniclastic material erupted from Mount Churchill mixed with the surrounding snow and ice, forming hyperconcentrated flood flows that completely inundated the Klutlan glacial valley and flowed at least $30 \mathrm{~km}$ downstream from the volcano. Evidence of this flooding event is preserved in terraces that reach approximately $20 \mathrm{~m}$ in thickness along the lateral margins of Klutlan Glacier (see Chapter 4). To date, similar evidence for lahar deposits has not been found in the Mount Churchill region, although perennial snow and ice cover in the region may presently hide such deposits.

Several factors intensify the potential for the development of flooding at the BonaChurchill massif during future volcanic events. Explosive activity could easily trigger the melting of the large volumes of snow or glacial ice sustained by high altitudes in the vent region, and the mixing of loose tephra on the flanks of the volcano with heavy rainfall or runoff could result in secondary lahars or floods, or large amounts of water and volcaniclastic sediment could become impounded behind natural volcanic or ice dams, the breakage of which could cause major downstream flooding. Volcanic eruptions are the third most common cause for the formation of natural dams $(\sim 8 \%)$ after rainfall and earthquake-triggered landslides (Costa and Schuster 1988) and usually 
produce larger floods because of the large amounts of volcaniclastic debris involved (Costa 1988; Macías et al. 2004). The past record of volcanic activity at Mount Churchill indicates the potential for future explosive activity and for the development of hyperconcentrated flood flows and natural dams, as demonstrated from significant quantities of tephra deposited on the flanks of the Klutlan glacial valley. If future eruptions were to occur during the winter, the amount of snow and ice on the summit would be greater than during the summer, substantially increasing the potential for floods.

Impacts from future flood flows and natural dams will likely reach distances of tens of kilometers from the vent area, particularly in drainage systems (Stasiuk et al. 2003; Figure 64). Drainages from the Klutlan and Russell Glaciers lead into the Generc and White Rivers respectively. The Generc and White Rivers are tributaries of the Yukon River, one of two principal drainage systems in the Yukon Territory (Wickstrom 1980). The Yukon River drainage system drains an area of $854,701 \mathrm{~km}^{2}(330,000$ miles $^{2}$ ) and flows $3702 \mathrm{~km}$ (2300 miles) from Canada into the Bering Sea (Yukon River Inter-Tribal Watershed Council 2002). The Alsek river system, to the south, drains the southern portion of Kluane National Park and Reserve, and drains into the Gulf of Alaska (Pacific Ocean), whereas the White River is fed by all waters of the northern slopes in Kluane National Park and Reserve (Wickstrom 1980). The White River, 
along with the Tanana River, provides about 30\% of the total water flow at the discharge of the mouth of the Yukon River; it also transports about 60 million tons of suspended sediment each year (Yukon River Inter-Tribal Watershed Council 2002). The principal drainage to the south from the Hawkins and Barnard Glaciers is via the Chitina River.

At first glance it would appear that the risk from flooding is mitigated somewhat by the large stretches of wilderness and the small number of permanent facilities and fixed infrastructures along the White River valley, but this is not the case. Indigeneous peoples of this watershed utlize the White River for many purposes, including drinking water, fishing and farming (salmon, whitefish, sheefish, burbot, and pike), transportation, bathing, ceremonial and traditional practices (Yukon River Inter-Tribal Watershed Council 2002). The water is also used for mining, agricultural irrigation, power plant coolant, primary and secondary contact recreation, electrical generation cooling, and sewage treatment (Yukon River Inter-Tribal Watershed Council 2002). In addition, the White River represents a major transport route between villages located along the river in Yukon and Alaska. Because these communities are not connected by roads, boats traverse the White River to move people, haul supplies, and remove commodities for trade or other purposes. Furthermore, the watershed provides habitat for diverse wildlife (moose, caribou, sheep, and other furbearers), and 
a rich growing environment for gardens and indigeneous plants, both of which indigeneous peoples depend upon for sustenance.

Flooding from future eruptions of Mount Churchill would also impact communities, transportation, communication, and infrastructures primarily in the White River valley, including the Alaska Highway (Stasiuk et al. 2003) and wildlife, temporary camps, and recreational users of the Kluane and Wrangell-St. Elias national park regions (Neal et al. 2002; Figure 64). An eruption could cause major melting of Klutlan Glacier and flooding in the Generc and White Rivers, which probably would destroy the Alaska Highway bridge near the community of Beaver Creek, approximately $80 \mathrm{~km}$ downstream from Mount Churchill. A portion of the Alaska Highway between Whitehorse and Haines Junction may also be affected by future volcanic activity, and could be costly to repair. Two access roads into the Wrangell-St.Elias National Park and Preserve run along the Chitina River might be affected if flooding of the Chitina River should occur (McGimsey et al. 1995).

On a more distal scale, growing populations and rapid development in the White River valley could increase the risk posed by flooding in the Churchill region. The confluence of the Generc and White Rivers is located $60 \mathrm{~km}$ upstream from the community of Beaver Creek, Yukon. Floods might be confined initially to the main 
channels, but in low-lying areas could spread laterally. Although the steep snowcovered slopes of Mount Churchill are potential sources of floods, the southern drainages are unlikely to be affected unless large-scale explosive activity changes the location of the northeasterly facing vent (Richter et al. 1995a). Therefore, although the risks posed to fisheries and camps to the south on the Chitina and Copper Rivers should be considered (McGimsey et al. 1995), these risks at these localities are likely to be low. In addition, secondary hazards related to activity from the volcano may be present for years after an eruption occurs (Stasiuk et al. 2003). The breakout-flow sequences of El Chichón formed nearly two months after a cataclysmic eruption and affected regions beyond those initially damaged by primary pyroclastic flows (Macías et al. 2004).

\section{Pyroclastic Flows and Surges}

Pyroclastic flows and surges, mixtures of hot gas and volcaniclastic debris, are potential hazards within tens of kilometers of Mount Churchill. It is difficult to predict the extent of future flows and surges from Mount Churchill because evidence of past equivalents (if they exist) have been covered by proximal snow and ice and/or by the erosive and depositional action of regional glaciers. The hazard boundary for flows and surges (Figure 64) would be limited to areas that are sparsely populated within Kluane and Wrangell-St. Elias National Parks. However, if an eruption were to occur in the 
summertime, large numbers of tourists and park staff may be affected by flows or surges. These deposits would be expected to reach at least several kilometers beyond the vent in any direction (Waythomas and Nye 2002). They would be emplaced at speeds exceeding $10 \mathrm{~m} / \mathrm{s}(36 \mathrm{~km} / \mathrm{h}$ or $23 \mathrm{mi} / \mathrm{h})$, and at temperatures greater than several hundred degrees Celsius or more (Waitt et al. 1995). Although the effects from flows or surges would be severe, a much larger area could be affected by the creation of floods, produced by mixing of flows and surges with snow and ice at the summit, impacting areas that are well downstream from the volcano.

\section{Socio-Economic Impact}

\section{Affected Areas and Populations}

Mount Churchill is located less than 300 kilometers from three-quarters of the population of Yukon. The largest number of residents live in the southern half of the territory $(30,963$ people) in the city of Whitehorse (23,272 people; Statistics Canada 2005). The territory experienced a $2.5 \%$ increase in population growth from June $2004(30,469$ people) to June 2005 (31,222 people) with over $75 \%$ of its communities demonstrating population growth (Table 6; Statistics Canada 2005). The majority of the population resides in Beaver Creek, Burwash Landing, Carcross, Carmacks, Dawson City, Destruction Bay, Faro, Haines Junction, Marsh Lake, Mayo, Old Crow, Pelly Crossing, Ross River, Tagish, Teslin, Watson Lake, and Whitehorse; only 111 
people reside in the communities of Champagne, Elsa, Jakes Corner, Johnsons Crossing, Keno City, Stewart Crossing, Swift River, and Upper Liard (Table 6; Statistics Canada 2005). Two major shortcomings associated with these statistics are: 1) They do not include residents from rural regions, and 2) They likely do not reflect the many groups of indigeneous peoples who live outside major community centres. It is also important to note that seasonal fluctuations in these population levels should be expected, as the population in the Park regions increases significantly during the summer tourist months.

Major population centres in Kluane National Park and Preserve include Beaver Creek (population: 120 people), Burwash Landing (population: 89 people), Destruction Bay (population: 59 people), and Haines Junction (population: 817; Statistics Canada 2005). The population within adjacent Wrangell-St. Elias National Park and Preserve in Alaska has increased from 8600 people in 1981 to over 10,000 people in 2001 (Table 6; United States Census Bureau 2000). The majority of the population within Wrangell-St. Elias National Park and Preserve resides in McCarthy, Kennicott, Copper Centre, Glennallen, Tok, and the coastal communities of Valdez, Cordova, and Yakutat (Table 6; United States Census Bureau), although the Park and Preserve is only $322 \mathrm{~km}$ (200 miles) east of Anchorage, the largest centre in Alaska. Recent increases in economic development, tourism, and the populations of Alaska and 
Yukon (particularly in the Park areas) are all beginning to contribute to increased risk factors from volcanic hazards.

Based on the statistics above, ash fallout from a future eruption of Mount Churchill (comparable in size and magnitude to the east lobe of White River ash) would affect approximately $95 \%$ of local residents (Figure 64), if prevailing winds remain the same. The only community that would not be affected is Old Crow, over $400 \mathrm{~km}$ north of Dawson City (Old Crow was barely affected by ashfall during the two earlier eruptions of White River ash). On the other hand, an eruption of similar scale and magnitude, directed north instead of east, would affect only $8 \%$ of Yukon's population. The majority of Yukon-Alaska residents would therefore be affected by future eruptions when ash is blown eastwards by prevailing winds. Most residents live in areas that would be marginally affected by ash fallout; for instance, Whitehorse houses nearly $75 \%$ of Yukon's population (23,272 people) and is likely to receive less than $2.54 \mathrm{~cm}$ ( 1 inch) of ash during a comparable east-lobe eruption. Haines Junction (817 people) and Dawson City (1,826 people) are both located in areas that are likely to receive less than $5 \mathrm{~cm}$ ( 2 inches) of ash fallout. It is estimated that at least 28,115 people would be affected by ash accumulations that are less than $5 \mathrm{~cm}$ (2 inches) thick in Yukon Territory. The communities that are most likely to be affected by future eruptions of Mount Churchill are those which lie in the zone of overlap because they are 
susceptible to ash blown northwards or eastwards. These communities include Beaver Creek, Carmacks, Pelly Crossing, Burwash Landing, and Destruction Bay (935 people; Statistics Canada 2005; Table 6).

\section{Natural Resources, Trade, and Industry}

Many people were originally employed in Wrangell-St. Elias National Park and Preserve in the 1970s during construction of the Trans-Alaska pipeline, which ends in Valdez, the site of major maintenance and loading operations. Although the TransAlaska pipeline is not situated within the Wrangell- St. Elias region, it was responsible for bringing an influx of people and businesses to the area. Today, several communities flourish in Wrangell- St. Elias Park and Preserve with coastal communities relying primarily on tourism and fishing industries and the interior towns (Tok, Glennallen, and Copper Centre) providing essential highway support services. Small communities in the Park and Preserve rely predominantly on agriculture, homesteading, mining, and a few small businesses (National Park Service 1986; Weeks 2003). Homesteads exist in isolated pockets throughout the vast expanses of wilderness that exist throughout the Park and Preserve. In addition, there are several indigeneous groups, such as the Ahtna, who continue to engage in traditional hunting, fishing, and gathering practices throughout the region (Weeks 2003). 
In Kluane National Park and Reserve, $40 \%$ of the labour force is currently employed by one of the four levels of the Yukon government, 15\% by the accomodation and food service industries, and $15 \%$ in the construction industry (Zanasi 2005). In the 1990s, several jobs were created with the transfer of the Aviation and Marine Branch to Haines Junction (Zanasi 2005). A significant proportion of residents within Kluane are employed by the Park itself, or provide essential highway support services to tourists. In the Kluane region, a significant proportion of the accomodation and food service industries as well as subsidiary industries are dependent on tourists who visit the area (Zanasi 2005).

\section{Tourism}

The allure of Kluane National Park and Reserve and contiguous Wrangell-St. Elias National Park and Preserve comes from breathtaking scenery and vast expenses of pristine wilderness. The parks form one of the United Nation's largest World Heritage Sites (Figure 10), which are valued for their natural (e.g. Galapagos Islands) or cultural attributes (e.g. Pompeii, the Taj Mahal, or the Great Wall of China). Not surprisingly, a significant number of tourists visit Kluane National Park and Reserve and Wrangell- St. Elias National Park and Preserve every summer. Recreational activities in the Park regions include backpacking, camping, fishing, hunting, and trapping. Kluane National Park and Reserve maintains approximately $200 \mathrm{~km}$ of trails 
and $400 \mathrm{~km}$ of hiking routes, ranging from 20 -minute walks to more difficult five- or six-day hikes (Parks Canada 2004). Several campgrounds and day use facilities, as well as visitor reception centres, are maintained by park officials and at points along the Alaska Highway.

In $1999,128,795$ visitors traveled the Alaska Highway through the Kluane region and at least 92,500 of these visitors stayed in the Kluane region for a reasonable duration of time (Zanasi 2005). In $2004,75,478$ non-residents spent an average of $\$ 42.50$ each, producing a revenue of $\$ 3.21$ million (Zanasi 2005). The commercial value of Kluane National Park and Reserve is therefore very significant to Yukon's economy. The population within the Park, as well as the tourism industry, has been steadily growing over the past decade. An influx of people living, working, and visiting the area has significantly increased the risk posed by volcanic hazards. In 2001, approximately 620 people were working in the Kluane region; 210 people worked full time and year round and 410 worked part-time, seasonally or both (Zanasi 2005).

\section{Impact on Yukon Economy}

The number of people living, working, and visiting Kluane National Park and Reserve has not only increased the risk posed by volcanic hazards, it has also created an economy that is dependent on the Park's tourism. Most of Yukon's gross national 
product comes from the construction, retail trade, and health care sectors (6-7\%) however regional (5.7\%) and local contributions (7.0\%) from the Park are significant (roughly $\$ 2.5$ million dollars; Zanasi 2005 ). Yukon communities that have focused on tourism in the past decade have been booming in recent years; in contrast, communities relying solely on natural resources have been in decline (Zanasi 2005). This relationship has placed extra stress on the tourism industry and its contributions to the region's economic sustainability (Zanasi 2005). Future eruptions of Mount Churchill would, in effect, destroy, or at least make areas of Kluane Park inhospitable for weeks to months, and would therefore have a severe effect on the region's economic stability.

\section{Impact on Aviation Economies}

Future emissions of ash from Mount Churchill would greatly affect aviation industries in Alaska and Yukon Territory. During the eruption of Redoubt volcano in 19891990, the cancellation of several hundred flights at Anchorage International Airport caused a loss of revenue of approximately $\$ 2.6$ million (Brantley 1990). Total losses from the Redoubt eruption are estimated at approximately $\$ 101$ million; this includes approximately $\$ 80$ million dollars in damage (Steenblik 1990) when a Boeing 747-400 flew into an ash cloud while attempting to land in Anchorage (Tuck and Huskey 1992, 1994; Waythomas et al. 1998). 
Future eruptions from Mount Churchill are likely to produce airborne ash hazards across much of western Canada, because prevailing winds in the area tend to move eastward (Figure 64). Mount Churchill lies beneath the flight path of at least 55-100 daily commercial or private routes to Anchorage, Alaska (McGimsey et al. 1995). From January 1996 to December 2000, there has been a 21\% increase in air-traffic routes in the Anchorage, Alaska region heightening the overall risk (Stasiuk et al. 2003; Creamer 2001). This usage of aircrafts in the Alaska region is expected to increase each year by approximately 5\% until 2020 (Creamer 2001).

\section{Environmental Impact}

The region surrounding Mount Churchill constitutes 4 parks and preserves which together are the largest recognized international protected wilderness areas in the world $\left(98,300 \mathrm{~km}^{2}\right.$; Danby 2003; Figure 10). These parks have been designated by the United Nations as a World Heritage Site, embracing various federal, state, provincial and territorial lands including Kluane National Park and Reserve in Yukon, Tatshenshini-Alsek Provincial Park in British Columbia, Wrangell-St. Elias National Park and Preserve and Glacier Bay National Park and Preserve in Alaska. Peripheral protected areas include Tetlin National Wildlife Refuge, Chugach and Tongass National Forests, Kluane Wildlife Sanctuary, and Chilkit Bald Eagle Preserve (Danby 
2003). In Kluane and Wrangell-St. Elias parks alone, there is $75,433 \mathrm{~km}^{2}$ of protected land which could be devastated by a future eruption, nearly $75 \%$ of which constitutes natural wilderness (Danby 2003; Stanford 2003).

The environmental impact of future eruptions is particularly significant in a region known for protecting its wildlife and diverse ecological habitats. The goals of Kluane and Wrangell parks are to ensure, preserve, and protect the integrity of ecological and heritage resources for present and future generations while fostering public understanding, appreciation, and use/enjoyment of the wilderness areas. Therefore, the impact of a future eruption on the park's biological and ecological assets (its flora, fauna and hydrological resources) must be assessed. Workman (1979) postulated that environmental impact of the previous eruptions from Mount Churchill were so devastating that they created a biological desert for a period of time. Depending on wind directions and patterns, any of the areas within the national parks or peripheral protected areas could be affected by ash dispersal. If the wind blows to the east or the north, as it has in the past, the primary areas that would be affected by fallout include Wrangell-St. Elias, Kluane, Kluane National Sanctuary, Tetlin, and possibly the northern parts of Tatshenshini-Alsek Provincial Park. Beacause much of the literature focuses on Kluane and Wrangell parks, and because it is these regions that will be most affected by volcanic hazards, the following assessment will concentrate primarily 
on the biology and ecology of these areas.

\section{Ecological Impact in National Park Regions}

\section{Kluane National Park and Reserve, Yukon Territory}

Kluane National Park and Reserve (KNPR) is Canada's largest park and reserve with an area of 22,013 $\mathrm{km}^{2}$ (Stanford 2003; Figure 10). Habitats within the park include glaciers, mountains, forests, tundra, streams, rivers, and wetlands (Harris 1980). The western boundary of KNPR and the Game sanctuary is the $141^{\text {st }}$ meridian longitude (the Alaska-Yukon border); the eastern boundary generally follows the Alaska Highway in the Shakwak valley. Its southern boundary is the 6oth parallel of latitude (the provincial boundary with British Columbia). The Park spans three climatic zones, resulting in very different temperature and precipitation regimes throughout the region (Wahl et al. 1987), and two ecozones (after Scudder 1987, based on Oswald and Senyk's 1977 ecoregion scheme and Bostock's 1948 physiographic divisions of the Yukon), the St. Elias-Coast Mountain ecozone and the Shakwak Trench ecozone. This ecoregion scheme is classified a little differently than the Ecological Stratification Working Group's terrestrial ecozones (1986) and ecoregions (1989) which is less specific to Yukon and composes an ecological framework for the whole of Canada (Scudder 1987). 


\section{Physiography}

The physiography of Kluane National Park is rugged and complex (Scudder 1987). There are two physiographic regions in KNPR and the Game Sanctuary: the mountain peaks and icefields, which consistute about $82 \%$ of the park; and the greenbelt, comprising subalpine and alpine forests which consistute the other $18 \%$, almost entirely in the eastermost third of the park (Parks Canada 2004). The most impressive mountain range is the St. Elias Mountains, containing peaks ranging from 8,500 to 13,500 feet in elevation (Bostock 1948; Rampton 1971a), 2,050 glaciers, and some of the largest non-polar icefields and glaciers in any subarctic region in the world (Campbell and Rampton 1980). The St. Elias mountain range can be subdivided into three geographic regions: the Icefield Ranges, Duke Depression, and Kluane ranges (Rampton 1971b). A well-known peak in the Icefield Range is Mount Logan, the highest in Canada (Scudder 1997; Muller 1967). These peaks support glaciers such as Klutlan, Steele, Kluane, and Donjek, which extend into low-lying valleys and feed the two major river systems (Generc and Donjek rivers) of the park. In contrast, the Duke Depression is a broad plateau characterized by maximum elevation of 5,000 feet (Muller 1967; Rampton 1971b). To the east, the Kluane Ranges contain peaks ranging from 6,000 to 7,500 feet elevation (Rampton 1971b), forming a rugged frontal ridge to the north of the remaining St. Elias Mountains (Scudder 1997) and separating the 
range from the five to ten-mile wide Shakwak Trench trending southeast to northeast (Muller 1967; Rampton Htravel route, also home to the Alaska ighway and many of the settlements, telephone lines, and pipelines in Yukon (Muller 1967).

\section{Flora and Fauna}

Kluane National Park and Reserve is home to some of the largest populations of wildlife in Canada, and some of the most distinct varieties of plants in the world thrive in the region. There are three basic eco-zones in Kluane's greenbelt: the grasslands in the topographically low regions and in valley bottoms, the montane forest zone of white spruce, aspen, and poplar, a subalpine zone, and an alpine tundra lacking trees with species such as arctic poppies, purple saxifrage, mountain heather, and moss campion. Within its $22,013 \mathrm{~km}^{2}$ area, KNPR has a total of 45 different mammal species; the most well-known of these species include coyotes, wolves, red foxes, black bears, grizzly bears, lynx, cougars, wolverines, caribou, moose, mule deer, mountain goats, and dall sheep (Danby 2003). Vegetation within Kluane National Park and Reserve reflects latitudinal and elevational temperature gradients (Scudder 1997). Overall, the $7 \%$ of the park/preserve that is forested is almost exclusively east of the park's icefields in valley bottoms, lower slopes, or montane regions below $1100 \mathrm{~m}$, and is most typically represented by black and white spruce (Kluane National Park and Preserve of Canada Management Report 2004). Subalpine vegetation, characterized by 
spruce-willow-birch ecosystems, occurs above the boreal forest line, and is composed of two subzones: a forested zone in lower altitudes and a shrub zone (treeless) in upper altitudes (Scudder 1997). At even higher altitudes, alpine tundra predominates and is characterized by low-lying plants such as mountain avens, alpine bearberry, tufted alpine saxifrage, prickly saxifrage, and crustose lichens (Scudder 1997). Only $18 \%$ of the park/reserve is vegetated (Parks Canada 2004). Smaller mammals such as shrews, squirrels, chipmunks, mice, hares, lemmings, voles, porcupines, pikas, bats, beavers, ermines, weasels, woodchucks, martens, and minks (Danby 2003) also make their home in vegetated regions. Bird life includes 168 confirmed, possible, and probable breeding bird species including the common loon, Canada goose, trumpeter swan, golden and bald eagles, peregrine falcon, sharp-shinned and red-tailed hawks, arctic tern, and several year-round residents, including the willow ptarmigan, spruce grouse, ravens, goshawks, and great-horned or northern-hawk owls (Danby 2003). At least 89 non-breeding bird species, particularly the asiatic, coastal, arctic, northern prairie, and western mountain species, are unique to the Kluane region.

\section{Wrangell-St. Elias National Park and Preserve, Alaska}

Wrangell St. Elias National Park and Preserve is the largest park and preserve in the United States $\left(53,420 \mathrm{~km}^{2}\right.$; Weeks 2003). The park is bounded by several geographic and political divisions; the Gulf of Alaska to the south, the Mentasta Mountains and 
the Tetlin National Refuge to the north, the Canadian border to the east, and the Copper River to the west (National Park Service 1983; Weeks 2003; Figure 10). Glaciers cover approximately $20 \%$ of the park's area (National Park Service 1998; Weeks 2003). Four mountain systems in the park and preserve border the the Gulf of Alaska and extend into northwestern British Columbia and southwestern Yukon Territory. Convergence of these mountain regions has produced a complex and rugged physiography in the park and preserve, as well as intensely variable climatic patterns and ecozones (Weeks 2003).

\section{Physiography}

The mountain ranges of Wrangell-St. Elias National Park and Preserve include the eastern Alaska Range, Wrangell Range, St. Elias Range, and Chugach Range (Weeks 2003; Figure 10). The contiguous Wrangell and St. Elias Ranges are heavily glaciated and are composed primarily of rugged volcanic peaks that extend eastward into Kluane National Park and Reserve (Denton 1974; Cook and Roland 2002). Most of the volcanoes have not erupted in Holocene time, with the exception of Mount Wrangell and Mount Churchill in the St. Elias Range. The Chugach range to the south borders the Gulf of Alaska, and the eastern Alaska Range forms the northern boundary of the Park/Preserve. 
The mountains within Wrangell-St. Elias National Park and Preserve belong to a belt of parallel mountain ranges separated by valleys and plateaus in the region's center and along its western and northwestern fringes. The region can be divided into four physiographic provinces: the Northern Plateaus (Northway-Tanacross Lowland), the Alaskan-Aleutian (the central and eastern part of Wrangell-St. Elias National Park and Preserve), the Coastal Trough (Copper River Lowland, Duke Depression, and Wrangell Mountains), and the Pacific Border Ranges (Kenai-Chugach Mountains, St. Elias Mountains, and the Gulf of Alaska coast: Weeks 2003).

\section{Flora and Fauna}

The diversity of landscape in Wrangell-St. Elias National Park and Preserve is reflected in its variable composition of the vegetation and fauna. The park is home to a unique combination of boreal and coastal ecosystems with floristic influences from Beringia, Yukon, and the Arctic and Pacific Mountain systems (Cook and Roland 2002). Due to the wide variety of climatic zones and elevations, Wrangell-St. Elias contains numerous ecosystem types ranging from coastal and interior types to gradations between the two (United States Department of the Interior 1974; Weeks 2003).

Vegetation in Wrangell-St. Elias National Park and Preserve ranges from alpine tundra to ground birch thickets and forest vegetation, depending on elevation of the region. 
Alpine tundra, consisting of low, matted alpine plants and mountain avens in dry regions, and sedges, grasses, and low-lying shrubs in moist areas, predominates at elevations between 1 to 1.5 metres ( 3 to 5,000 feet above tree-line; Weeks 2003). On steep hillsides, alder thickets predominate and thickets of ground birch dominate the elevational areas between tundra and forests (Weeks 2003). Lower altitude regions are characterized by forest vegetation, including white spruce along river valleys, and and birch, balsam poplar, aspen, and white spruce in upland regions (Weeks 2003). Black and white spruce taiga characterize the interior of the park/preserve, with willows along the riparian area of streams and forests of Sitka spruce and Western hemlock in coastal regions (National Park Service 1986; Weeks 2003). At lower elevations, wetlands occur adjacent to streams and lakes, wet tundra, shallow tundra ponds, wet shrub scrub, and forested wetlands, supporting aquatic invertebrates, fish populations, and waterfowl (Weeks 2003).

Plant communities in a subarctic region like Wrangell-St. Elias National Park and Preserve are diverse partly because of the park's large size (5.3 million hectares), the variation in climate (Interior, Montane, and Transitional), and the wide variety of land, flora, and lithological influences (Cook and Roland 2002). The region contains a variety of unique plants that are endemic to the region. An inventory of the vascular flora of the park suggests there are at least 884 vascular plant species in the 
park/preserve (National Park Service 2003), many of which were previously undescribed, yet endemic to the area, and are now classified as rare plants (Weeks 2003). The inventory discovered 11 new species in the flora of the park/preserve, 3 occurrences of species identified by the U.S. Fish and Wildlife Service as species of concern, 362 occurrences of 69 rare plants, 30 Alaska-Yukon endemics, and 52 significant range extensions (new to south-central Alaska and greater than $200 \mathrm{~km}$ from previous collections; Weeks 2003). One endemic plant, Cryptantha shackletteana (Boraginaceae), Shacklette's cryptantha, was previously only known from its type locality in Eagle, Alaska (Weeks 2003). A number of other rare or threatened plant species can be found in the area including the Alaska nagoon berry (Rubus articus stellatus), fragile sedge (Carex membranacea) and wedge-leaved primrose (Primula cuneifolia saxifragifolia) as well as Montia bostockii (National Park Service 1998; Weeks 2003).

The prolification of diverse vegetation in the Wrangell-St. Elias region has produced equally diverse wildlife populations. The most well-known species within WrangellSt. Elias are brown/grizzly bears, black bear, moose, caribou, wolf, trumpeter swans, bald and golden eagles, dall sheep, and mountain goats (Weeks 2003). The region supports a similar faunal population as seen in Kluane National Park and Reserve, with the exception of a few groups of animals such as chipmunks, woodchucks, mice, ermine, weasels, river otters, cougars, and mule deer (Danby 2003). In addition, 
Wrangell-St. Elias is home to some species not found in Kluane National Park and Reserve, including marmots, muskrats, and bison (Danby 2003). The prevalence of wetlands throughout Wrangell-St. Elias has resulted in the prolification of birds; 146 different types of breeding birds and 35 types of non-breeding birds currently make their home in the region (Danby 2003). The river systems and streams are also spawning areas for three types of salmon (including red, silver, and king) as well as several fish species such as rainbow trout, lake trout, grayling, dolly varden, and burbot (Weeks 2003).

\section{Biodiversity in the St. Elias Region}

In Alaska, British Columbia, and the Yukon, Kluane National Park and Reserve, Wrangell-St. Elias National Park and Preserve, Tatshenshini-Alsek Provincial Park, and Glacier Bay National Park and Preserve protect a total of 178 species of confirmed, probable, and potential breeding birds, and 48 species of terrestrial mammals (Danby 2003). Comparatively, Tetlin National Refuge $\left(3,739 \mathrm{~km}^{2}\right)$ supports 40 mammals, 119 breeding birds, and 67 non-breeding birds, and Tatshenshini-Alsek Provincial Park $\left(9,580 \mathrm{~km}^{2}\right)$ supports 131 breeding birds, 31 non-breeding birds, and 39 mammals (Danby 2003). Glacier Bay National Park and Preserve in Alaska (13,355 $\mathrm{km}$ ) supports 108 breeding birds, 115 non-breeeding birds, and 29 mammals (Danby 2003). According to a recent publication by Danby (2003), this combined area 
supports roughly $10-30 \%$ more species than expected in patterns of continental diversity. Because of the range of so many species typical of various ecosystems (arctic, boreal, cordilleran, and coastal) and the variety of species, subspecies, and varieties common to the region, and because the St. Elias region is located at the convergence of all these zones, it has been termed a "biogeographic crossroads" (Spector 2002; Danby 2003).

\section{Affects to Biodiversity}

\section{Flora}

Volcanoes, whether they produce effusive or explosive activity, have profound effects on the flora and fauna of surrounding environments (McDowall 1996). Immediate impacts from ashfall may affect landforms, soil composition, and on a larger broader scale may impact the whole ecosystem through reduction or elimination of plant or animal species (Mean et al. 1982). Ash accumulation less than $1 \mathrm{~cm}$ thick has, in some instances, damaged large areas of vegetation, temporarily clogging streams, and altering wildlife habitats for several years (Neal et al. 2001). In areas proximal to the volcanic source, vegetation may be flattened, buried, burned upon impact, or smothered by thick deposits of ash, pyroclastic flows, or debris/mud flows (McDowall 1996; Clarkson et al. 1988). In these areas, stem or limb bending/breakage may occur in response to mechanical loading (Lowdermilk 1947; Eggler 1959; Cook et al. 1981; 
Mack 1981). During the Mount St. Helens eruption in 1980 (less than ten times the size of the eruption that produced the east lobe ash), $350 \mathrm{~km}^{2}$ of nearby forest was blown down, $116 \mathrm{~km}^{2}$ was scorched, $127 \mathrm{~km}^{2}$ was affected by debris and mud flows, and up to $20 \mathrm{~km}^{2}$ was affected in the vent region or by pyroclastic flows (Mean et al. 1982). Large-scale eruptions can thus create a biological desert over large areas; fauna that subsist on the vegetation would, in most cases, starve to death in response to its destruction.

Longer-term effects on vegetation include erosive effects, major changes in soil composition, and the impedement of seedling establishment. Since ash and pumice is essentially composed of particles of glass, the erosion of ash can have a severe sandblasting effect on plant surfaces and pollinating insects (Griggs 1918). If ash deposits are thick and unstable, the recovery of vegetation may be slowed by the inability of seeds to sprout and for roots to reach deeper into soil layers uncontaminated by ash (Griggs 1918; Eggler 1959; Frenzen and Franklin 1985; Antos and Zobel 1986). Seedling growth is also slowed when successive wetting and drying of the ash creates an impenetrable hard crust (Eggler 1959; Antos and Zobel 1985; Frenzen and Franklin 1985), increasing albedo, reducing gas exchange and evaporation from underlying soil, and restricting water infiltration (Cook et al. 1981; Antos and Zobel 1985; Frenzen and Franklin 1985). Precipitation may mitigate these effects somewhat by increasing the 
stability of the tephra (Eggler 1959; Oner and Oflas 1977, Cook et al. 1981).

Thin layers of tephra can destroy vegetation, irrigation systems, and crops. As a soil, ash tends to have a low water retention capability (Wood and del Moral 1987; Chapin and Bliss 1989; Wood and Morris 1990) and it is often low or lacking in nutrients, especially nitrogen (Eggler 1959; Wilcox 1959; Antos and Zobel 1986). The accumulation of ash on leaves and other plant surfaces can lead to the slowing or prevention of photosynthesis, when the ash acts as a light barrier and/or clogs leaf stomata (Cook et al. 1981). Other widespread short-term problems may include salt damage of fruits and plants and/or a reduction in water absorption due to damaged plant cuticles (Cook et al. 1981; Wood and del Moral 1987; Chapin and Bliss 1989; Wood and Morris 1990).

Revegetation after future eruptions from Mount Churchill would be rapid in regions where surviving plants could sprout in buried ash-free soil (Mean et al. 1982). In areas where the ash fall is extremely thick, revegetation may not take place until the ash is sufficiently eroded and to allow roots to quickly reach nutrient-rich soil (Mean et al. 1982). In central Washington, after the eruption of Mount St. Helens (1980), the regrowth of Pinus ponderosa increased several fold when roots reached a buried soil layer 60-100 $\mathrm{cm}$ beneath coarse ash and pumice (Hermann and Peterson 1969; Mean 
et al. 1982). The composition of the tephra also determines whether or not it is a good candidate for vegetative regrowth (Mean et al. 1982). If the tephra is high in nitrogen and phosphorus, it will aid plant growth by fertilization, but the tephra also needs to have a high cation exchange capacity (Mean et al. 1982). If the cation exchange capacity is low, then fertilizing ions will move out of the tephra quickly (Mean et al. 1982). As vegetative regrowth occurs, creating hospitable micro-habitats that can provide increased resources, animals will gradually re-colonize such vegetative areas (McDowall 1996).

\section{Fauna}

Presumably, the greatest effects to terrestrial fauna will be from inhospitable environments and lack of food resources. During future eruptions of Mount Churchill, extensive defaunation of ecosystems within Kluane and Wrangell-St. Elias National Parks can be expected, with the effects of eruptions continuing to be damaging to the east (dependent on wind direction), decreasing in severity with increasing distance from the volcano (McDowall 1996). Grazing animals, such as caribou, deer, and moose, would be affected initially by thick deposits of ash covering their primary food source and could be harmed or killed by ingesting ash-covered vegetation (Neal et al. 2001). Carnivores relying on herbivores would be phased out 
more slowly, as their food supply diminished. Ash also would impact smaller animals, particularly insects, affecting their ability to fly, and abrading their epicuticular wax layer, which is the insect's main means of protecting against desiccation (Cook et al. 1981). During the eruption of Mount St. Helens in 1980, adult house flies, brownbanded cockroach nymphs, adult orchard mason bees, yellowjackets, honey and pollinator bees, and wasps were especially affected by ash from the eruption; the latter species were affected mostly because of their highly mobile nature and dense covering of body hair that trapped the ash (Cook et al. 1981).

Ashfalls tend to have a greater impact on aquatic ecosystems than on their terrestrial counterparts and these have been studied in considerable detail in relation to the 1980 eruption of Mount St. Helens (McDowall 1996). Immediate impacts on aquatic biota include fast-flowing debris or mud flows up to 32 degrees Celsius (Bison, Nielsen, and Ward 1988; Wissmar et al. 1990), and long-term effects such as increased sediment supply in connecting river systems (McDowall 1996), the production of partially or completely anaerobic systems because of microbial activity stimulated by a higher level of nutrients (Ward et al. 1983), increased turbidity, and the disruption of olfactory migration for species such as salmon (McDowall 1996). In the Mount Churchill region, it is likely that the Generc and White Rivers would be completely depopulated of fauna as the result of ash-laden floods and increased sediment supply. 


\section{Endangered Species}

Kluane National Park and Reserve and Wrangell-St. Elias National Park and Preserve support significant numbers of rare and endangered flora and fauna (Table 8). The grizzly bear, considered to be a special species of concern in Canada, is very susceptible to human activities as is the "blue" or "glacier" bear, a colour phase of the black bear endemic to Yukon Territory and considered rare in Alaska. Wood bison, which are threatened in Canada, and pockets of habitat for the eastern endangered wolverine in northern Alberta and Northwest Territories (Stanford 2003) might also be affected by future volcanic eruptions. Table 8 lists animals of endangered, threatened, or special concern in Yukon and Alaska that are potentially at risk from future eruptions of Mount Churchill. Depending on the size and magnitude of future volcanic events (as well as the direction of prevailing winds) several "at risk" species could potentially be affected in British Columbia, Alberta, and the Northwest Territories.

\section{Global Climate}

Large magnitude high-intensity eruptions, such as the events that produced the White River ash, typically produce ash clouds of sufficient height (30-35 km; Downes 1979) to cause disturbance of the stratosphere, thereby affecting climate patterns and 


\begin{tabular}{|c|c|c|c|c|}
\hline & Mammals & Birds & Amphibians & Fish \\
\hline Endangered $^{1}$ & & $\begin{array}{l}\text { Eskimo curlew } \\
\text { (Numenius borealis) }\end{array}$ & & \\
\hline \multirow[t]{3}{*}{ Threatened $^{2}$} & \multirow[t]{3}{*}{$\begin{array}{l}\text { Wood bison (Bison bison } \\
\text { atbabascae) }\end{array}$} & $\begin{array}{l}\text { Falcon } \\
\text { subspecies, Peregrine } \\
\text { (Falco peregrinus anatum) }\end{array}$ & & \\
\hline & & $\begin{array}{l}\text { Spectacled } \\
(\text { Somateria fischen })^{+}\end{array}$ & & \\
\hline & & $\begin{array}{l}\text { Steller's eider (Polysticta } \\
\text { stellen })^{+}\end{array}$ & & \\
\hline \multirow[t]{4}{*}{ Special Concern $^{3}$} & $\begin{array}{l}\text { Grizzly bear (Ursus } \\
\text { arctos) }\end{array}$ & 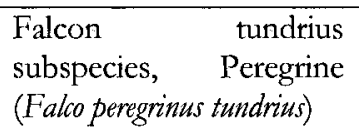 & \multirow{4}{*}{$\begin{array}{l}\text { Westem toad (Bufo } \\
\text { boreas) }\end{array}$} & \multirow{4}{*}{$\begin{array}{l}\text { Squanga whitefish (Coregonus } \\
\text { sp.) }\end{array}$} \\
\hline & $\begin{array}{l}\text { Polar bear (Ursus } \\
\text { maritumus) }\end{array}$ & $\begin{array}{l}\text { Ivory gull (Pagophila } \\
\text { eburnea) }\end{array}$ & & \\
\hline & $\begin{array}{l}\text { Woodland caribou } \\
\text { (Rangifer tarandus caribou) }\end{array}$ & $\begin{array}{l}\text { Short eared owl (Asio } \\
\text { flammeus) }\end{array}$ & & \\
\hline & Wolverine (Gulo gulo) & & & \\
\hline \multirow{10}{*}{$\begin{array}{l}\text { Potentially At } \\
\text { Risk* }\end{array}$} & & \multirow[t]{5}{*}{ High risk: } & & High risk: \\
\hline & & & & $\begin{array}{l}\text { Pygmy whitefish (Prosopium } \\
\text { coulterii) }\end{array}$ \\
\hline & & & & Mid risk: \\
\hline & & & & $\begin{array}{ll}\text { Artic cisco } & \text { (Corgonus } \\
\text { autumnalis) } & \end{array}$ \\
\hline & & & & $\begin{array}{l}\text { Least cisco (Coregonus } \\
\text { sardinella) }\end{array}$ \\
\hline & & \multirow[t]{5}{*}{$\begin{array}{l}\text { Canada warbler (Wilsonia } \\
\text { Canadensis) }\end{array}$} & & $\begin{array}{l}\text { Dolly varden (Salvelinus } \\
\text { malma) }\end{array}$ \\
\hline & & & & $\begin{array}{l}\text { Lake trout (Salvelinus } \\
\text { bamaycusb) }\end{array}$ \\
\hline & & & & Low risk: \\
\hline & & & & $\begin{array}{l}\text { Broad whitefish (Coregonus } \\
\text { nasus) }\end{array}$ \\
\hline & & & & $\begin{array}{l}\text { Arctic grayling (Thymallus } \\
\text { arcticus, includes Beringian, } \\
\text { Nahanni, and Missouri } \\
\text { forms) }\end{array}$ \\
\hline
\end{tabular}

Table 8: A list of ${ }^{1}$ endangered, ${ }^{2}$ threatened, ${ }^{3}$ special concern, and ${ }^{*}$ potentially at risk species in Yukon Territory last updated by the Committee on the Status of Endangered Wildlife in Canada (COSEWIC) in 2003. 'Endangered wildlife refers to species approaching extirpation or extinction. ${ }^{2}$ Threatened species are likely to become endangered if current trends are not reversed. ${ }^{3}$ Special concern species are particularly vulnerable to human activities or natural events. ${ }^{*}$ Refers to species not yet assessed by COSEWIC. + Lists threatened species in Alaska last updated by the United States Fish and Wildlife Service in June 2004. 
weather beyond the national level. Unusual light effects, similar to those created after eruption of Krakatau in 1883, may produce exceptionally intense red skies, and bluegreen coloration of the sun and moon. Such effects may be created by water vapour released from the eruption which condenses and freezes in the upper atmosphere (Simkin and Fiske 1983). In addition, the release of several tons of sulphur dioxide into the stratosphere (which converts into sulphate aerosols) may scatter solar energy, resulting in anomalous cooling of the lower atmosphere. These particles may remain suspended for years before settling to the surface, causing local cooling of the north polar region for many years, and temporarily reversing the impact of climate warming. This might result in increased sea ice coverage which would affect future shipping via the Northwest Passage.

\section{Discussion}

Hazard assessment and risk analysis are becoming increasingly important as the population of the world continues to increase, putting more people at risk from volcanic eruptions and especially for communities that continue to thrive and expand near active and dormant volcanic centres. In the past century, people have become more exposed to natural hazards, including volcanic eruptions (Chester et al. 2002). In 1993, Tilling and Lipman wrote that the world population at risk from volcano hazards in the year 2002 would be at least 500 million, a figure that they compared to 
the estimated world population at the beginning of the seventeenth century. Volcanic eruptions already have cost our global economy an estimated $\$ 10$ billion dollars, and will continue to cost even more in the future. Although those living close to active volcanoes are usually aware of the costs and hazards, the risks often are not understood or fully appreciated in volcanologically active regions like Alaska where eruptions occur infrequently or after long periods of dormancy (Scandone 1983; Wilcox 1959). In several active volcanic regions around the world (e.g. Alaska, Italy, Japan, U.S.A., and Central America), an increase in population and in economic development has made volcanic hazard assessment a necessity (Scandone 1983).

The attraction of people to the slopes of volcanoes is complex and can be related to the interplay of economic, social, and cultural forces reflected in population growth and migration, and changes in the distribution of wealth and poverty both within individual countries and globally (Chester et al. 2002). For instance, 600,000 people live on or near the volcanic slopes of Somma-Vesuvius in Italy, and 3 million people live within the eruptive range of this volcano (Kilburn and McGuire 2001). Tourism continues to grow in Naples as well, increasing volcanic risk.

Because most volcanoes have longer repose periods than a person's lifetime, the average person may be unaware that many volcanoes are dormant rather than extinct. 
In very general terms, eruptions of roughly 100 cubic kilometres tend to occur every 10,000 years and those of 1,000 cubic kilometres about every 100,000 years. Furthermore, geologists must be careful not to assume that just because an eruption has never occurred historically in a particular location that it will not happen in the future (e.g. Paricutin, Mexico (1943-52), Pinatubo, Philippines (1991), and Novarupta (1912)). This type of volcanic activity where eruptions occur infrequently or after long periods of dormancy is of particular concern in Alaska, where explosive eruptions tend to occur in the absence of previously documented historical records.

Changing perceptions in the last few decades have led to a major shift in how volcanic risks around the world are assessed and managed. For example, the eruption of Mount St. Helens in the Pacific Northwest in 1980 stimulated increased concern for seeking ways in volcanic risks can be reduced. Recent activity of Augustine Volcano (2005-06; Lovick 2006), Mount Redoubt (1989; Waythomas et al. 1998), and Crater Peak (Mount Spurr, 1992; Waythomas and Nye 2002) has also provoked public education and outreach initiatives about Alaskan volcanoes (Adleman et al. 2006). This type of approach, which focuses on the physical parameters of volcanic activity (frequencies, areal extent, durations) and public education/outreach initiatives that take into account social and economic consequences, is becoming increasingly common (Warrick 1975), especially in regions where active volcanism occurs in close 
proximity to major population centres.

Crediblity is a particularly difficult issue in the assessment of volcanoes which have not erupted in recent history, e.g. Mount Pinatubo, which did not erupt historically until 1991 (Punongbayan et al. 1996). Most people are content to accept that a volcano's recent behaviour is characteristic of its future behaviour. For example, many Canadians are complacent in their attitude towards volcanic eruptions and hazards (Stasiuk et al. 2003) since Canada has not had a significant record of historical volcanic activity. However, long-term volcano hazard assessments in any region must be based on knowledge of the volcano's eruptive style and history (magnitude, nature and quantity of past eruptions, age, stratigraphy, and reconstruction). This knowledge must be obtained before a volcanic crisis strikes and is crucial in mitigating future volcanic events (Tilling and Lipman 1993).

\section{Future Studies}

Long-term research is needed to continuously assess natural hazards from future eruptions of Mount Churchill. Currently, the volcano is not geophysically monitored, a step that would, at the very least, identify signs of restless activity, including earthquakes, ground cracking and swelling, gas emissions, increases in temperature, or even small steam-drive explosions. Tiltmeters are recommended to measure surface 
deformation, as are seismic stations and possibly sensors for detecting volcanic gas emissions. It would be extremely beneficial to install satellite remote sensing systems for examination of changes in volcanic behavior in real time (e.g. surface and/or thermal changes) and systems for lahar detection, given the potential for flooding demonstrated during past eruptive events. A recent initiative in 2005 by the Consortium of United States Volcano Observatories resulted in a document that recommends monitoring levels for all potentially dangerous volcanoes in the United States (Ewert et al. 2005). In this report, Mount Churchill is classified as a "high threat volcano" along with Novarupta (Katmai National Park) and Mount Wrangell in the WVF; other Aleutian eruptive centres such as Augustine Volcano, Mount Redoubt, or Mount Spurr which have shown activity in the past few decades are classified as "very high threat volcanoes." Recommendations for monitoring of "high threat volcanoes" similar to Mount Churchill include seismic, deformation, gas, hydrologic, and remote sensing in real time (Ewert et al. 2005).

More detailed case studies, such as those presented in this dissertation, are needed to continue to help to predict the path and size of future volcanic events. These case studies will assist with prediction of future volcanic activity at Mount Churchill and primary and secondary hazards associated with the interaction of tephra with snow and ice. In addition, detailed stratigraphic studies of pumice terraces that border 
glaciers elsewhere in the world will contribute further to our understanding of potential hazards. Detailed field studies, including regional hazard mapping in addition to the work completed in this dissertation, should also be completed to further elucidate future patterns of eruptive activity for Mount Churchill.

Communication is key to informing the residents of Yukon and Alaska of the imminent or possible dangers associated with eruptions from Mount Churchill. Communities exposed to risks from future eruptions should be made fully aware of the hazards and the attendant risks to life and property. Appropriate educational activities might include planning or emergency-reponse workshops or exercises, the distribution of educational materials (including fact sheets similar to those already produced by the Alaska Volcano Observatory, booklets or brochures on the White River ash (West and Donaldson in press), video programs, maps, or musuem exhibits) to Park visitor centres, the media, and local schools or community centres.

\section{Conclusions}

The timing of future volcanic events from Mount Churchill is uncertain and requires further investigation. The primary hazards from future eruptions include ash fallout, lahars, hyperconcentrated flood flows, and possibly, pyroclastic flows or surges. Ash fallout could affect areas as far as hundreds of kilometers away from the volcanic 
source, and would have a catastrophic effect on the wildlife and vegetation of Kluane and Wrangell-St. Elias National Park areas. Floods would inundate the Generc and White River drainages and could lead to the development of natural volcanic debris dams. Thick accumulations of ash and pumice in proximal areas would clog drainages and persist for months to years after the eruption. Because the immediate area around Mount Churchill is mostly uninhabited, few facilities and people would be at risk from proximal hazards. However, communities located farther from the volcano, especially in Yukon and Alaska, would be at risk from distal hazards, and would experience a significant impact on their predominantly tourist-based economies.

In the past, eruptions of Mount Churchill have been infrequent events. The likelihood of future events is probably less than one in a thousand in any given year which is improbable from a planning perspective. However, the eruptions of long-dormant volcanoes such as Paricutin, Mexico (1943-1952) Pinatubo, Philippines (1991), and Novarupta (1912) are important because they remind us that infrequent catastrophic events, however, improbable, are entirely possible (White 1980). The key steps in mitigating the impact of future eruptions from Mount Churchill are education, communication, awareness of hazards, understanding of potential impacts, and taking appropriate precautions (Neal et al. 2001). It is too late to gather information about a volcano's prior history once an eruption begins, and thus, an effective response to the 
disaster may not be possible at such a late stage. At an early stage, information about

hazards should be integrated into regional planning, including infrastructure upgrades, land use, and development in potentially affected areas (Neal et al. 2001). Recreational users of the Kluane and Wrangell-St. Elias regions should be advised of potential volcanic hazards in the region, particularly those associated with ashfall, pyroclastic flows or surges, and hyperconcentrated flood flows (Waythomas et al. 1998). In addition, an emergency plan outlining the potential impacts of future eruptions should be developed in collaboration with public officials, scientists, and land managers (Waythomas et al. 1998; Neal et al. 2001). Minimizing the risks is possible through adequate warning of potential hazards, and by avoiding development or utilization of areas likely to be seriously affected by future eruptions. It is hoped that information presented in this thesis will contribute to the encouragement of geoscientists and political decision-makers to develop appropriate programs to increase public awareness of volcanic hazards in North America, with special attention to the particular hazards posed by Mount Churchill, Alaska. As harshly demonstrated by recent major geohazards such as the Boxing Day Tsunami and the New Orleans flood, renewed efforts to advance geohazard mitigation are urgently needed. 


\section{References}

Adleman, J.N., Snedigan, S. and Wallace, K. 2006. Alaska Volcano Observatory: Outreach, education, and communication, one eruption at a time. Geological Society of America Abstracts with Programs, 38: 516.

Alaska Volcano Observatory. 2007. Fourpeaked Volcano. Information release, Thursday, May 3, 2007. Retrieved May 25, 2007, from http://www.avo.alaska.edu.

Allen, J.R.L. 1984. Sedimentary structures: their character and physical basis, Volume I. Developments in Sedimentology, 30. Elsevier, Amsterdam.

Allen R. and McPhie J. 2000. Water settling and resedimentation of submarine rhyolitic pumice at Yali, Eastern Aegean, Greece. Journal of Volcanology and Geothermal Research, 95: 285-307.

American Automobile Association. 1999. Alaska Northwest Canada. Map 98-12, Scale 1:4,000,000.

Antos, A.A. and Zobel, D.B. 1985. Upward movement of underground plant parts into deposits of tephra from Mount St. Helens. Canadian Journal of Botany, 63: 2091 2096.

Antos, A.A. and Zobel, D.B. 1986. Seedling establishment in forests affected by tephra from Mount St. Helens. American Journal of Botany, 73: 495-499.

Ball, R., Sir. 1902. The eruptions of Krakatoa. The National Geographic Magazine, 13: 200 .

Begét, J.E. and Nye, C.J. 1994. Postglacial eruption history of Redoubt volcano, Alaska. Journal of Volcanology and Geothermal Research, 62: 31-54.

Berger, A.R. 1960. On a recent volcanic ash deposit, Yukon Territory. Proceedings of the Geological Association of Canada, 12: 117-118.

Best, J.L. 1992. Sedimentology and event timing of a catastrophic volcaniclastic mass flow, Volcan Hudson, southern Chile. Bulletin of Volcanology, 54: 299-318.

Beverage, J.P. and Culbertson, J.K. 1964. Hyperconcentrations of suspended sediment. American Society of Civil Engineers, Proceedings, Hydraulics Division Journal, 90 (\#HY6): 117-128.

Blong, R.J. 1984. Volcanic hazards: A sourcebook on the effects of eruptions. Academic Press, Orlando, Florida. 
Blong, R.L. 1982. The time of darkness: Local legends and volcanic reality in Papua New Guinea. University of Washington Press, Seattle.

Boggs, S. 2001. Principles of sedimentology and stratigraphy. ( ${ }^{\text {rd }}$ edition). Prentice Hall, Upper Saddle River, New Jersey.

Borns, H.W., Jr. and Goldthwait, R.P. 1969. Late-Pleistocene fluctuations of Kaskawulsh glacier; southwestern Yukon Territory, Canada. American Journal of Science, 264: 600-619.

Bostock, H.S. 1952. Geology of the northwest Shakwak Valley, Yukon Territory. Geological Survey of Canada, Memoir 267.

Bostock, H.S. 1969. Kluane lake: Its drainage and allied problems. In Icefield Ranges Research Project Scientific Results Volume 1. Edited by V.C. Bushnell and R.H. Ragle. American Geographical Society and the Arctic Institute of North America, pp.187-196.

Brayshay, M. and Grattan, J. 1999. Environmental and social responses in Europe to the 1783 eruption of the Laki fissure volcano in Iceland: a consideration of contemporary documentary evidence. In Volcanoes in the Quaternary. Edited by C.R. Firth and W.J. McGuire. Geological Society of London Special Publication 161, London, England, pp.173-187.

Bridge, J.S. and Best, J. 1988. Flow, sediment transport, and bedform dynamics over the transition from dunes to upper-stage plane beds: implications for the formation of planar laminae. Sedimentology, 35: 753-763.

Bridge, J.S. and Best, J. 1997. Preservation of planar laminae due to migration of lowrelief bed waves over aggrading upper-stage plane beds: comparison of experimental data with theory. Sedimentology, 44: 253-262.

Brooks, A.H. 1900. A reconnaissance from Pyramid Harbor to Eagle City, Alaska, including a description of the copper deposits of the upper White and Tanana rivers. United States Geological Survey, $21^{\text {st }}$ Annual Report, Part II, pp. 331-391.

Bruns, T.R. 1983. Model for the origin of the Yakutat block, an accreting terrane in the northern Gulf of Alaska. Geology, 11: 718-721.

Buddington, A.F. and Lindsley, D.H. 1964. Iron-titanium oxide minerals and synthetic equivalent. Journal of Petrology, 5: 310-357.

Campbell, R.B. and Rampton, V.N. 1980. The story of the rocks and glaciers. In Kluane: pinnacle of the Yukon. Edited by J.B. Theberge. Doubleday Canada Limited, Toronto, Ontario, pp.3-17. 
Capps, S.R. 1915. An ancient volcanic eruption in the upper Yukon basin. U.S. Geological Survey Professional Paper 95-D, pp.59-64.

Cas, R.A.F. and Wright, J.V. 1987. Volcanic successions: Modern and ancient. Allen and Unwin, London, England.

Cas R.A.F. and Wright J.V. 1991. Subaqueous pyroclastic flows and ignimbrites: an assessment. Bulletin of Volcanology, 53: 357- 380.

Casadevall, T.J. 1994. The 1989-1990 eruption of Redoubt Volcano, Alaska: Impacts on aircraft operations. Journal of Volcanology and Geothermal Research, 62: 301-316.

Casadevall, T.J., Delos Reyes, P.J., and Schneider, D.J. 1996. The 1991 Pinatubo eruptions and their effects on aircraft operations. In Fire and mud: eruptions and lahars of Mount Pinatubo, Philippines. Edited by C.G. Newhall and R.S. Punongbayan. Philippine Institute of Volcanology and Seismology and University of Washington Press, Quezon City, Philippines and Seattle, pp.1071-1088.

Chapin, D.A. and Bliss, L.C. 1989. Seedling growth, physiology, and survivalship in a subalpine volcanic environment. Ecology, 70: 1325-1334.

Chester, D.K. 1993. Volcanoes and society. Academic Press, Orlando, Florida.

Chester, D.K., Dibben, C., Coutinho, R., Duncan, A.M., Cole, P.D., Guest, J.E. and Baxter, P.J. 1999. Human adjustments and social vulnerability to volcanic hazards: the case of Furnas volcano, São Miguel, Açores. In Volcanoes of the Quaternary. Edited by C.R. Firth and W.J. McGuire. Geological Society of London Special Publication 161, London, England, pp. 189-207.

Chester, D.K., Dibben, C.J.L., and Duncan, A.M. 2002. Volcanic hazard assessment in western Europe. Journal of Volcanology and Geothermal Research, 115: 411-435.

Clague, J.J., Evans, S.G., Rampton, V.N. and Woodsworth, G.J. 1995. Improved age estimates for the White River and Bridge River tephras, western Canada. Canadian Journal of Earth Sciences, 32: 1172-1179.

Clague, J., Jozsa, A., and Parker, M.L. 1982. Dendrochronological dating of glacierdammed lakes: An example from Yukon Territory, Canada. Arctic and Alpine Research, 14: 301-310.

Clark, D.W. 1992. The Archaic in the extreme northwest of North America. Revista de Arqueologia Americana, 5: 71-99. 
Clarkson, B.R., Patel, R.N. and Clarkson, B.D. 1988. Composition and structure of forest overwhelmed at Pureora, central North Island, New Zealand, during the Taupo eruption (c. AD 130). Journal of the Royal Society of New Zealand, 18: 417-436.

Collins, B.D., Dunne, T. and Lehre, A.K. 1983. Erosion of tephra-covered hillslopes north of Mount St. Helens, Washington: May 1980-May 1981. Zeitschrift fur Geomorphologie Neue Folge Supplementband, 46, 103-121.

Collinson, J.D. and Thompson, D.B. 1989. Sedimentary structures. Chapman and Hall, London.

Collinson, J.D. 1996. Alluvial sediments. In Sedimentary environments: processes, facies and stratigraphy. Edited by H.G. Reading. Blackwell Science, Oxford, UK, pp.37-82.

Cook, R.J., Barron, J.C., Papendick, R.I. and Williams, G.J. 1981. Impact on agriculture of the Mount St. Helens eruptions. Science, 211: 16-22.

Cook, J.P. and McKennan, R. 1970. The Athapaskan tradition. A view from Healy Lake in the Yukon-Tanana upland. Paper presented at the $10^{\text {th }}$ annual meeting of the Northeastern Anthropological Association, Ottawa, Ontario.

Cook, M.B. and Roland, C.A. 2002. Notable vascular plants from Alaska in WrangellSt. Elias National Park and Preserve with comments on the floristics. Canadian FieldNaturalist, 116: 192-304.

Costa, J.E. 1988. Rheologic, geomorphic, and sedimentologic differentiation of water floods, hyperconcentrated flows, and debris flows. In Flood geomorphology. Edited by V.R. Baker, R.C. Kochel, and P.C. Patton. John Wiley and Sons, New York, Pp. 113122.

Costa, J.E. and Schuster, R.L. 1988. The formation and failure of natural dams. Geological Society of America Bulletin, 100: 1054-1068.

Crampton, C.B. 1982. Volcanic ash soils in the southern Yukon of Canada. Muskox, 30: 81-84.

Creamer, S.P. 2001. Informal airspace workshop; Air traffic control airspace and procedures for Anchorage terminal area, Anchorage, Alaska. Retrieved May 25, 2007, from http://www.epa.gov/cgi-bin/epaprintonly.cgi.

Cronin, S.J., Neall, V.E., Lecointre, J.A. and Palmer, A.S. 1996. Unusual "snow slurry" lahars from Ruapehu volcano, New Zealand, September 1995. Geology, 24: 1107-1110. 
Cross, T.A. and Pilger, R.H., Jr. 1982. Controls of subduction geometry, location of magmatic arcs, and tectonics of arc and back-arc regimes. Geological Society of America Bulletin: 93: 545-562.

Cruikshank, J. 1981. Legend and landscape: Convergence of oral and scientific traditions in the Yukon Territory. Arctic Anthropology, 18(2): 67-93.

Danby, R.K. 2003. Birds and mammals of the St. Elias mountain parks: Checklist evidence for a biogeographic convergence zone. The Canadian Field Naturalist, 117: $1-18$

Dawson, G.M. 1888. Report on the exploration in the Yukon district, N.W.T. and adjacent northern portion of British Colombia, 1887. In Geological and natural history survey of Canada. Edited by the Dawson Brothers, Montreal, Quebec, pp. 43B-46B.

Denton, G.H. 1974. Quaternary glaciations of the White River valley, Alaska with a regional synthesis for the northern St. Elias mountains, Alaska and Yukon Territory. Geological Society of America Bulletin, 85: 871-892.

Denton, G.H. and Armstrong, R.L. 1969. Miocene-Pliocene glaciations in southern Alaska. American Journal of Science, 267: 1121-1142.

Denton, G.H. and Stuiver, M. 1966. Neoglacial chronology, northeastern St. Elias mountains, Canada. American Journal of Science, 264: 577-599.

Denton, G.H. and Stuiver, M. 1967. Late Pleistocene glacial stratigraphy and chronology, northeastern St. Elias mountains, Yukon Territory, Canada. Geological Society of America Bulletin, 78: 485-510.

Denton, G.H. and Stuiver, M. 1969. Neoglacial chronology, northeastern St. Elias mountains, Canada. In Icefield Ranges Research Project Scientific Results Volume 1. Edited by V.C. Bushnell and R.H. Ragle. American Geographical Society and the Arctic Institute of North America, pp.173-186.

Derry, D.E. 1975. Later Athapaskan prehistory: a migration hypothesis. The Western Canadian Journal of Anthropology, 5: 134-147.

Donaldson, J.A. and Mueller, W. 1993. Alluvial dispersal of tephra from Klutlan Glacier, Yukon. Geological Association of Canada- Mineralogical Association of Canada Abstracts with Programs, 18: A24.

Donaldson, J.A. and Mueller, W. 1994. Dispersal of pumice along Klutlan Glacier, Yukon Territory. Geological Society of America Abstracts with Programs, 26: A113.

Donaldson, J.A., Guerstein, P.G. and Mueller, W. 1995. Sedimentology and stratigraphy of pumiceous terraces beside Klutlan Glacier, Yukon Territory. Geological 
Association of Canada- Mineralogical Association of Canada Abstracts with Programs, 20: A25.

Donaldson, J.A., Guerstein, P.G. and Mueller, W. 1996. Facies analysis of a pumiceous terrace beside Klutlan Glacier, Yukon Territory. Canadian Journal of Earth Sciences, 33: $1233-1242$.

Downes, H. 1979. The White River ash, Yukon Territory: a petrologic study. M.Sc thesis, University of Calgary, Calgary.

Downes, H. 1985. Evidence for magma heterogeneity in the White River ash (Yukon Territory). Canadian Journal of Earth Sciences, 22: 929-934.

Driscoll, F.G., Jr. 1980. Formation of the Neoglacial surge moraines of the Klutlan Glacier, Yukon Territory, Canada. Quaternary Research, 14(1): 19-30.

Eggler, W.A. 1959. Manner of invasion of volcanic deposits by plants with further evidence from Paracutin and Jorullo. Ecological Monographs, 29: 267-284.

Environment Canada. 2007a. Canadian climate normals, 1971 to 2000.

Meteorological Service of Canada. Retrieved May 24, 2007, from

http://climate.weatheroffice.ec.gc.ca/climate normals/index e.html.

Environment Canada 2007b. Climate data online, Yukon Territory. Meteorological Service of Canada. Retrieved May 24, 2007, from

http://climate.weatheroffice.ec.gc.ca/climateData/canada e.html.

Ewert, J.W. Guffanti, M., and Murray, T.L. 2005. An assessment of volcanic threat and monitoring capabilities in the United States: Framework for a national volcano early warning system (NVEWS). United States Geological Survey, Open File Report 20051164.

Fernald, A.T. 1962. Radiocarbon dates relating to the widespread volcanic ash deposit, eastern Alaska. United States Geological Survey Professional Paper 450-B.

Field, W.O. 1975. Mountain glaciers of the northern hemisphere. Corps of Engineers, U.S. Army, Technical Information Analysis Center, Cold Regions Research Engineering Laboratory, Hanover, N.H.

Fierstein, J. and Hildreth, W. 2000. Preliminary volcano-hazard assessment for the Katmai volcanic cluster, Alaska. U.S. Geological Survey, Open-File Report 00-489.

Fisher, R.V. 1961. Rocks composed of volcanic fragments and their classification. Earth-Science Reviews, 1: 287-298. 
Fisher, R.V. and Schmincke, H.-U. 1984. Pyroclastic rocks. Springer-Verlag, Berlin.

Fowler, W.R. 1977. Linguistic evidence for Athapaskan prehistory. In Problems in the prehistory of the North American subarctic: The Athapaskan question. Edited by J.W. Helmer, S. Van Dyke, and F.J. Kense. Archaeological Association of the University of Calgary, Alberta, pp. 102-105.

Freidel, D.E. 1992. Geomorphic response of an incised river to pyroclastic sediment input from the eruption of Mount Mazama: Terracing along the north Umpqua river, western Oregon. Abstracts, Association of American Geographers, 88: 76.

Frenzen, P.M. and Franklin, J.F. 1985. Establishment of conifers from seed on tephra deposited by the 1981 eruptions of Mount St. Helens, Washington. The American Midland Naturalist, 114: 84-97.

Froese, D.G. 2007. The White River ash: Radiocarbon, ice core, and Byzantine records of a northern Athapaskan disaster. Atlas Seminar, Department of Earth and Atmospheric Sciences, University of Alberta. Retrieved May 18, 2006 from http://associations.eas.ualberta.ca/atlas/Seminar-Abstracts/2006-2007/Froese.pdf.

Gardner, J.E. 1993. Compositional diversity in volcanic deposits: Implication for processes operating within magma chambers and the withdrawal of magma during explosive Plinian eruptions. Ph.D. thesis, University of Rhode Island.

Griggs, R.F. 1918. The recovery of vegetation at Kodiak. Ohio Journal of Science, 19: $1-57$.

Guest, J.E., Duncan, A.M. and Chester, D.K. 1988. Monte Vulture volcano (Basilicata, Italy): An analysis of morphology and volcaniclastic facies. Bulletin of Volcanology, 50: 244-257.

Guest, J.E., Duncan, A.E., and Chester, D.K. 1991. Monte Vulture volcano (Basilicata, Italy): An analysis of morphology and volcaniclastic facies. A reply. Bulletin of Volcanology, 53: 228-229.

Hanson, L.W. 1965. Size distribution of the White River ash, Yukon Territory. M.Sc. thesis, University of Alberta, Edmonton.

Hare, G., Greer, S., Gotthardt, R., Farnell, R., Bowyer, V., Schweger, C. and Strand, D. 2004. Ethnographic and archaeological investigations of alpine ice patches in southwest Yukon, Canada. Arctic, 57(3): 260-272.

Harris, S.L. 2000. Archaeology and volcanism. In Encyclopedia of volcanoes. Edited by H. Sigurdsson, B. Houghton, S.R. McNutt, H. Rymer, and J. Stix. Academic Press, San Diego, pp.1301-1313. 
Hayes, C.W. 1892. An expedition through the Yukon District. National Geographic Magazine, 4: 117-162.

Hermann, R.K. and Peterson, R.G. 1969. Root development and height increment of Ponderosa pines in pumice soils of central Oregon. Forest Science, 15: 226-237.

Hickson. C.J. 1994. Volcanism in the Canadian Cordillera: Canada's hazard response preparedness. In Volcanic ash and aviation safety: proceedings of the first international symposium on volcanic ash and aviation safety. Edited by Thomas J. Casadevall. United States Geological Survey Bulletin 2047, United States Government Printing Office, Washington, pp.47-55.

Hickson, C.J., Spurgeon, T.C., Cocking, R.B., Russell, J.K., Woodsworth, G.J., Ulmi, M., and Rust, A.C. 2007. Tseax Volcano: A deadly basaltic eruption in north-western British Columbia's Stikine volcanic belt. Geological Society of America, Cordilleran Section, $103^{\text {rd }}$ Annual Meeting (4-6 May 2007). Retrieved May 28, 2007 from http://gsa.confex.com/gsa/2007CD/finalprogram/abstract 121306.htm.

Ingram, R.L. 1954. Terminology for the thickness of stratification and parting units in sedimentary rocks. Bulletin of the Geological Society of America, 65: 937-938.

Jensen, B.J.L. and Froese, D.G. 2006. Characterization and revised distribution of the White River ash in Yukon Territory and eastern Alaska. 36 ${ }^{\text {th }}$ International Arctic Workshop, March 16-19, 2000. Institute of Arctic and Alpine Research, University of Colorado at Boulder, Colorado, U.S.A. Retrieved May 24, 2007, from http://cgrg.geog.uvic.ca//abstracts/JensenCharacterizationThe.html.

Johnson, F. 1944. An archaeological survey along the Alaska Highway. American Antiquity, 11: 3.

Johnson, F. and Raup, H.M. 1964. Investigations in southwest Yukon: Geobotanical and archaeological reconnaissance. Papers of the Robert S. Peabody Foundation for Archaeology, Volume 6. Phillips Academy, Andover.

Kataoka, K. and Nakajo, T. 2002. Volcaniclastic resedimentation in distal fluvial basins induced by large-volume explosive volcanism: The Ebisutoge-Fukuda tephra, PlioPleistocene boundary, central Japan. Sedimentology, 49: 319-334.

Kilburn, C. and McGuire, B. 2001. Italian volcanoes. Terra Publishing, England, 166p.

Krafft, M. 1993. Volcanoes. Fire from the earth. Harry N. Abrams, Inc., New York. 
Krauss, M.E. 1972. Na-Dene. Current trends in linguistics, 10:146-206.

Krauss, M. and Golla, V. 1981. Northern Athapaskan languages. In Handbook of North American Indians. Volume 6, Subarctic. Edited by J. Helm. Smithsonian Institution, Washington, D.C., pp.67-87.

Lacroix, A. 1904. La Montagne Pelee et ses eruptions. Masson et Cie, Paris.

Lahr, J.C. and Plafker, G. 1980. Holocene Pacific-North American plate interaction in southern Alaska: implications for the Yakataga seismic gap. Geology, 8: 483-486.

Lajoie, J. and Stix, J. 1992. Volcaniclastic rocks. In Facies models: response to sea level change. Edited by R.G. Walker and N.P. James. Geological Association of Canada, St. John's, Newfoundland, pp.101-118.

Lehre, A.K., Collins, B.D., and Dunne, T. 1983. Post-eruption sediment budget for the North Fork Toutle River drainage, June 1980-June 1981. Zeitschrift fur Geomorphologie Neue Folge Supplementband Neue Folge Supplementband 46: 143-163.

Lerbekmo, J.F., Hanson, L.W., and Campbell, F.A. 1968. Application of particle size distribution to determination of source of a volcanic ash deposit. Proceedings of the $23^{\text {rd }}$ International Geological Congress, Prague, Section 2, pp.283-295.

Lerbekmo, J.F. and Campbell, F.A. 1969. Distribution, composition, and source of the White River ash, Yukon Territory. Canadian Journal of Earth Sciences, 6: 109-116.

Lerbekmo, J.F., Westgate, J.A., Smith, D.G.W., and Denton, G.H. 1975. New data on the character and history of the White River volcanic eruption, Alaska. In Quaternary studies. Edited by R.P. Suggate and M.M. Cresswell. Royal Society of New Zealand, Wellington, pp. 203-209.

Lowdermilk, W.C. 1947. Erosional phenomena associated with volcanic eruption of Paricutan, Mexico. EOS, Transactions of the American Geophysical Union 28: 269270.

Lovick, J. 2006. The 2006 Augustine eruption in synthetic aperture data. Geological Society of America Abstracts with Programs, 38: 28.

Lowdon, J.A. and Blake, W., Jr. 1968. Geological Survey of Canada radiocarbon dates VII. Radiocarbon, 12: 207-245.

Macíus, J.L., Capra, L., Scott, K.M., Espíndola, J.M., García-Palomo, A., and Costa, J.E. 2004. The 26 May 1982 breakout flows derived from failure of a volcanic dam at El Chichón, Chiapas, Mexico. Geological Society of America Bulletin, 116: 233-246. 
Mack, R.M. 1981. Initial effects of ashfall from Mount St. Helens on vegetation in eastern Washington and adjacent Ideaho. Science, 213: 537-539.

MacKevett, E.M., Jr. 1978. Geologic map of the McCarthy quadrangle, Alaska. U.S. Geological Survey Miscellaneous Investigations Series Map I-1032.

MacNeish, R.S. 1964. Investigations in southwest Yukon: Archaeological excavations, comparisons, and speculations. Papers of the Robert S. Peabody Foundation for Archaeology, Volume 6. Phillips Academy, Andover.

Major, J.J., Janda, R.J., and Daag, A.S. 1996. Watershed disturbance and lahars on the east side of Mount Pinatubo during the mid-June 1991 eruptions. In Fire and mud: eruptions and lahars of Mount Pinatubo, Philippines. Edited by C.G. Newhall and R.S. Punongbayan. Philippine Institute of Volcanology and Seismology and University of Washington Press, Quezon City, Philippines and Seattle, pp.895-919.

Major, J., Janda, R., Pierson, T., Waitt, R., LaHusen, R., Trabant, D., Scott, W., Brabets, T. and Miller, T. 1990. Debris flows and floods generated by eruption of Redoubt volcano, Alaska: consequences of interaction between snow and ice and volcanic debris.

Geological Society of America, Abstracts with Programs, 22: A55.

Major, J.J. and Newhall, C.J. 1989. Snow and ice perturbation during historical volcanic eruptions and the formation of lahars and floods: a global review. Bulletin of Volcanology, 52: 1-27.

Major, J.J., Pierson, T.C., Dinehart, R.L. and Costa, J.E. 2000. Sediment-yield following severe volcanic disturbance- a two-decade perspective from Mount St. Helens. Geology, 28: 819-822.

Manville, V. 2001. Sedimentology and history of Lake Reporoa: An ephemeral supraignimbrite lake, Taupo volcanic zone, New Zealand. In Volcaniclastic sedimentation in lacustrine settings. Edited by J.D.L. White and N.R. Riggs. International Association of Sedimentologists Special Publication 30, pp.109-140.

Manville, V., Hodgson, K.A., Houghton, B.F., Keys, J.R.(H.) and White, J.D.L. 2000. Tephra, snow and water: complex sedimentary responses at an active snow-capped stratovolcano, Ruapehu, New Zealand. Bulletin of Volcanology, 62: 278-293.

Manville, V., White, J.D.L., Houghton, B.F. and Wilson, C.J.N. 1998. The saturation behaviour of pumice and some sedimentological implications. Sedimentary Geology, 119: 5- 16.

Marsh, W.M. 1987. Earthscape. A physical geography. John Wiley \& Sons, Inc, Canada. 
Mashiotta, T.A., Thompson, L.G., and Davis, M.E. 2004. The White River ash: New evidence from the Bona-Churchill ice core record. Eos Transactions, American Geophysical Union, 85(47), Fall Meeting, Abstract PP21A-1369.

McDowall, R.M. 1996. Volcanism and freshwater fish biogeography in the northeastern North Island of New Zealand. Journal of Biogeography, 23: 139-148.

McGimsey, R.G., Richter, D.H., DuBois, G.D. and Miller, T.P. 1990. A postulated new source for the White River ash, Alaska. In Geologic studies of Alaska, 1990. Edited by D.C. Bradley and A.B. Ford. United States Geological Survey, Bulletin 1999, pp. 212218.

McGimsey, R.G., Richter, D.H., Waythomas, C.F. and Donaldson, J.A. 1995.

Potential hazards from future eruptions of Mount Churchill, Alaska. Geological Society of America Abstracts with Programs, 27: 63.

Mean, J.E., McKee, W.A., Moir, W.H., and Franklin, J.F. 1982. Natural revegetation of the northeastern portion of the devastated area. In Mount St. Helen's: One year later. Edited by S.A.C. Keller. Eastern Washington University Press, Spokane, pp. 93103.

Melson, W.G., Allan, J.F., Jerez, D.R., Nelen, J., Calvache, M.L., Williams, S.N., Fournelle, $J$ and Perfit, M. 1990. Water contents, temperatures, and diversity of the magmas of the catastrophic eruption of Nevado del Ruiz, Colombia, November 13, 1985. Journal of Volcanology and Geothermal Research, 41: 97-126.

Meyer, D.F., Janda, R.J., and Martinson, H.A. 1982. Initial and subsequent drainage basin and channel responses. The 1980 eruptions of Mount St. Helens. EOS, Transactions of the Geophysical Union, 63: 174.

Meyer, D.F. and Trabant, D.C. 1995. Lahars from the 1992 eruptions of Crater Peak, Mount Spurr volcano, Alaska. In The 1992 eruptions of Crater Peak vent, Mount Spurr volcano, Alaska. Edited by T.E.C. Keith. U.S. Geological Survey Bulletin 2139.

Miall, A.D. 1977. A review of the braided-river depositional environment. Earth Science Review, 13: 1-62.

Miall, A.D. 1978. Facies types and vertical profile models in braided river deposits: A summary. In Fluvial sedimentology. Edited by A.D. Miall. Canadian Society of Petroleum Geologists, Memoir 5, pp. 597-604.

Miall, A.D. 1992. Alluvial deposits. In Facies models: response to sea level change. Edited by R.G. Walker and N.P. James. Geological Association of Canada, St. John's, Newfoundland, pp.119-142. 
Mileti, D.S., Bolton, P.A., Fcrnandez, G., and Updike, R.G. 1991. The eruption of Nevado del Ruiz volcano, Colombia, South America, November 13, 1985. National Academy Press, Washington, D.C.

Miller, T.P., McGimsey, R.G., Richter, D.H., Riehle, J.R., Nye, C.J., Yount, M.E. and Dumoulin, J.A. 1998. Historically active volcanoes of Alaska. United States Geological Survey, Open File Report 98-582.

Miller, T.P. and Richter, D.H. 1994. Quaternary volcanism in the Alaska Peninsula and Wrangell Mountains, Alaska. In The geology of Alaska. Edited by G. Plafker and H.C. Berg. Geological Society of America, Geological Society of North America, v.G-1, Boulder, Colorado, pp.759-779.

Moffit, F.H. and Knopf, A. 1910. Mineral resources of the Nabesna-White River district, Alaska, with a section on the Quaternary by R.S. Capps. United States Geological Survey Bulletin 417, pp.1-64.

Montgomery, D.R., Panfil, M.S., and Hayes, S.K. 1999. Channel-bed mobility response to extreme sediment loading at Mount Pinatubo. Geology, 27: 271-274.

Moodie, D.W., Catchpole, A.J.W., and Abel, K. 1992. Northern Athapaskan oral traditions and the White River volcano. Ethnohistory, 39: 148-171.

Muller, J.E. 1967. Kluane Lake map-area. Geological Survey of Canada Memoir, Ottawa, Ontario.

National Park Service. 1983. Statement for management, Wrangell - Saint Elias National Park. Alaska Region, Anchorage, Alaska.

National Park Service. 1986. General management plan, land management plan, wilderness suitability review. Wrangell-St. Elias National Park and Preserve, Alaska.

National Park Service. 1998. Resources management plan. Wrangell-St. Elias National Park and Preserve. Copper Center, Alaska.

National Park Service. 2003. Vascular floristic inventory. Wrangell-St. Elias National Park and Preserve. Retrieved Auguest 15, 2004, from http://www.nps.gov/wrst/botany.htm.

Naranjo, J.L., Sigurdsson, H., Carey, S.N. and Fritz, W. 1986. Eruption of the Nevado del Ruiz volcano, Colombia, on 13 November 1985: tephra fall and lahars. Science, 233: 961-963.

Neal, C.A., McGimsey, R.G., Miller, T.P., Riehle, J.R. and Waythomas, C.F. 2001. Preliminary volcano-hazard assessment for Aniakchak volcano, Alaska. U.S. 
Geological Survey, Open File Report 00-519.

Newhall, C., Hendley, J.W., II, and Stauffer, P.J. 2005. Benefits of volcano monitoring far outweigh costs- The case of Mount Pinatubo. U.S. Geological Survey, Fact Sheet 115-97, Online version 1.1. Retrieved May 25, 2007 from http://pubs.usgs.gov/fs/1997/fs115-97.

Newhall, C.G. and Punongbayan, R.S. 1996. Fire and mud: Eruptions and lahars of Mount Pinatubo, Philippines. University of Washington Press, Seattle and London.

Newhall, C.F. and Self, S. 1982. The volcanic explosivity index (VEI): an estimate of explosive magnitude for historical eruptions. Journal of Geophysical Research, 87: 1241-1238.

Nye, C.J. 1983. Petrology and geochemistry of Okmok and Wrangell volcanoes, Alaska. Ph.D. thesis, University of California, Santa Cruz.

Oner, M. and Oflas, S. 1977. Plant succession on the Kula volcano in Turkey. Vegetation, 34: 55-62.

Oswald, E.T. and J.P. Senyk. 1977. Ecoregions of Yukon Territory. Fisheries and Environment Canada, Canadian Forestry Service, Pacific Forest Research Centre Information Report BC-X-164.

Office of the United Nations Disaster Relief Coordinator (UNDRO) and United Nations Educational Scientific and Cultural Organization, United Nations. 1985. Developing a volcano emergency plan. In Volcanic emergency management. United Nations, New York.

Page, R.A., Stephens, C.D. and Lahr, J.C. 1989. Seismicity of the Wrangell and Aleutian Wadati-Benioff zones and the North America plate along the Trans-Alaska crustal transect, Chugach mountains and Copper River basin, southern Alaska. Journal of Geophysical Research, 94: 16,059-16,082.

Palmer, B.A. and Walton, A.W. 1990. Accumulation of volcaniclastic aprons in the Mount Dutton Formation (Oligocene-Miocene), Marysvale volcanic field, Utah. Geological Society of America Bulletin, 102: 734-748.

Paola, C., Wiele, S.M., and Reinhart, M.A. 1989. Upper-regime planar lamination as the result of turbulent sediment transport and low-amplitude bedforms. Sedimentology, 36: 47-59.

Parks Canada. 2004. Kluane National Park and Reserve Management Plan. Retrieved November 20, 2005 from http://www.pc.gc.ca/pn-np/yt/kluane/plan/plan E.asp. 
Péwé, T. 1975. Quaternary geology of Alaska. U.S. Geological Survey Professional Paper 835.

Picard, M.D. and High, L.R., Jr. 1973. Sedimentary structures of ephemeral streams. Developments in Sedimentology, 17. Elsevier, Amsterdam.

Pierson, T.C. 1995. Flow characteristics of large eruption-triggered debris flows at snowclad volcanoes: constraints for debris-flow models. Journal of Volcanology and Geothermal Research: 66: 283-294.

Pierson, T.C., Daag, A.S., Reyes, P.J.D., Regalado, Ma.T.M., Solidum, R.U. and Tubianosa, B.S. 1996. Flows and deposition of post-eruption hot lahars on the east side of Mount Pinatubo, July-October 1991. In Fire and mud: eruptions and lahars of Mount Pinatubo, Philippines. Edited by C.G. Newhall and R.S. Punongbayan. Philippine Institute of Volcanology and Seismology and University of Washington Press, Quezon City, Philippines and Seattle, pp.921-950.

Pierson, T.C., Janda, R.J., Umbal, J.V. and Daag, A.S. 1992. Immediate and long-term hazards from lahars and excess sedimentation in rivers draining Mount Pinatubo, Philippines. United States Geological Survey Water Resources Publication 92-4039, pp.183-203.

Pierson, T.C. and Janda, R.J. 1994. Volcanic mixed avalanches: a distinct eruptiontriggered mass-flow process at snow-clad volcanoes. Geological Society of America Bulletin, 106: 1351-1358.

Pierson, T.C., Janda, R.J., Thouret, J.C., Borrero, C.A. 1990. Perturbation and melting of snow and ice of Nevado del Ruiz, Columbia, and consequent mobilization, flow and deposition of lahars. Journal of Volcanology and Geothermal Research, 41: 17-66.

Pierson, T.C. and Scott, K.M. 1985. Downstream dilution of a lahar: transition from debris flow to hyperconcentrated streamflow. Water Resources Research, 21: 1511-1524.

Pflaker, G., Lull, J.S., Nockleberg, W.J., Pessel, G.H., Wallace, W.K. and Winkler, G.R. 1989. Geologic map of the Valdez A-4, B-3, B-4, C-3, C-4 and D-4 quadrangles, northern Chugach mountains and southern Copper River basin, Alaska. U.S. Geological Survey Open-File Report 89-0569.

Plafker, G. and Berg, H.C. 1994. Overview of the geology and tectonic evolution of Alaska. In The geology of Alaska. Edited by G. Plafker and H.C. Berg. Geological Society of America, Decade of North American Geology, v. G-1, pp.989-1021.

Porter, S.C. and Denton, G.H. 1967. Chronology of neoglaciation in the North American Cordillera. American Journal of Science, 265: 177-210. 
Preece, S.J. 1997. Geochemical variation in the $<5 \mathrm{Ma}$ Wrangell volcanic field, Alaska with an emphasis on the Skookum Creek volcanic complex. Ph.D. thesis, Miami University, Florida.

Punongbayan, R.S., Newhall, C.G., Bautista, L.P., Garcia, D., Harlow, D.H., Hoblitt, R.P., Sabit, J.P. and Solidum, R.U. 1996. Eruption hazard assessments and warnings. In Fire and mud: eruptions and lahars of Mount Pinatubo, Philippines. Edited by C.G. Newhall and R.S. Punongbayan. Philippine Institute of Volcanology and Seismology and University of Washington Press, Quezon City, Philippines and Seattle, and University of Washington Press, Quezon City, Philippines and Seattle, pp. 67-85.

Rampton, V.N. 1969. Pleistocene geology of the Snag-Klutlan area, southwestern Yukon Territory, Canada. Ph.D. thesis, University of Minnesota, Minneapolis.

Rampton, V.N. 1970. Neoglacial fluctuations of the Natazhat and Klutlan Glaciers, Yukon Territory, Canada. Canadian Journal of Earth Sciences, 7: 1236-1263.

Rampton, V.N. 1971a. Late Pleistocene glaciations of the Snag-Klutlan area, Yukon Territory. Arctic, 24: 277-300.

Rampton, V.N. 1971b. Late Quaternary vegetational and climatic history of the SnagKlutlan area, southwestern Yukon Territory, Canada. Geological Society of America Bulletin, 82: 959-978.

Reading, H.G. 1990. Sedimentary environments: processes, facies, and stratigraphy. Blackwell Science: Oxford.

Reger, R.D. 1968. Recent history of Gulkana and College glaciers, central Alaska Range, Alaska. Journal of Geology, 76: 2-16.

Richter, D.H., Smith, J.G., Lanphere, M.a., Dalrynple, G.B., Reed, B.L. and Shew, N. 1990. Age and progression of volcanism, Wrangell volcanic field, Alaska. Bulletin of Volcanology, 53: 29-44.

Richter, D.H., Preece, S.J., McGimsey, R.G. and Westgate, J.A. 1995a. Mount Churchill, Alaska: Source of the late Holocene White River ash. Canadian Journal of Earth Sciences, 32: 741-748.

Richter, D.H., Rosenkrans, D.S. and Steigerwald, M.J. 1995b. Guide to the volcanoes of the western Wrangell Mountains, Alaska- Wrangell-St. Elias National Park and Preserve. U.S. Geological Survey Bulletin 2072.

Riggs, N.R., Ort, M.H., White, J.D.L., Wilson, C.J.N., Houghton, B.F. and Clarkson, R. 2001. Post-1.8 ka marginal sedimentation in Lake Taupo, New Zealand: effects of wave energy and sediment supply in a rapidly rising lake. In Volcaniclastic sedimentation in 
lacustrine settings. Edited by J.D.L. White and N.R. Riggs. International Association of Sedimentologists Special Publication 30, location, pp.151-177.

Robinson, S.D. 2001. Extending the late Holocene White River ash distribution, northwestern Canada. Arctic, 54: 157-161.

Rust, B.R. 1978. Depositional models for braided alluvium. In Fluvial sedimentology. Edited by A.D. Miall. Memoir, Canadian Society of Petroleum Geology, Calgary, 5: 605625.

Scandone, R. 1983. Problems related with the evaluation of volcanic risk. In Forecasting volcanic events. Edited by $\mathrm{H}$. Tazieff and J.C. Sabroux. Developments in Volcanology 1, Elsevier, Amsterdam, pp. 57-67.

Schmid, R. 1981. Descriptive nomenclature and classification of pyroclastic deposits and fragments: Recommendations of the IUGS subcommission on the systematics of igneous rocks. Geology, 9: 41-43.

Schneider, D.J., Rose, W.I. and Kelley, L. 1995. Tracking of 1992 eruption clouds from Crater Peak vent of Mount Spurr volcano, Alaska. In The 1992 eruptions of Crater Peak vent, Mount Spurr volcano, Alaska. Edited by T.E.C. Keith. U.S. Geological Survey Bulletin 2139.

Schwatka, F. 1885. Along Alaska's great river. Cassel and Company: New York. (Reprinted 1983, Alaska Northwest Publishing Company, Anchorage).

Schuster, R.L. 1981. Effects of the eruptions on civil works in the Pacific Northwest. In The 1980 eruptions of Mount St. Helens, Washington. Edited by P.W. Lipman and D.R. Mullineaux. United States Professional Paper 1250, pp. 701-718.

Scott, K.M. 1988. Origins, behaviours, and sedimentology of lahars and lahar-runout flows in the Toutle-Cowlitz river system. United States Geological Survey Professional Paper 1447-A, 74pp.

Scott, K.M., Janda, R.J., De la Cruz, E.G., Gabinete, E., Eto, I., Isada, M., Sexon, M. and Hadley, K.C. 1996. Channel and sedimentary responses to large volumes of 1991 volcanic deposits on the east flank of Mount Pinatubo. In Fire and mud: Eruptions and lahars of Mount Pinatubo, Philippines. Edited by C.G. Newhall and R.S. Punongbayan. Philippine Institute of Volcanology and Seismology and University of Washington Press, Quezon City, Philippines and Seattle, pp. 971-988.

Scudder, G.G.E. 1997. Environment of the Yukon. In Insects of the Yukon. Edited by H.V. Danks and J.A. Downes. Biological Survey of Canada (Terrestrial Arthropods), Ottawa, Ontario. 
Segerstrom, K. 1950. Erosion studies at Paricutin. State Michoacan, Mexico. United States Geological Survey Bulletin 965-A.

Segerstrom, K. 1966. Paricutin 1965- Aftermath of eruption. In Geological Survey Research 1966. United States Geological Survey Professional Paper 550-C, pp. 93-101.

Segschneider, B., Landis, C.A., and White, J.D.L. 2002. Resedimentation of the $1.8 \mathrm{ka}$ Taupo ignimbrite in the Mohaka and Ngaruroro river catchments, Hawke's Bay, New Zealand. New Zealand Journal of Geology and Geophysics, 45: 85-101.

Sharp, R.P. 1951. Glacial history of Wolf Creek, St. Elias range, Canada. Journal of Geology, 59: 97-115.

Shipley, S., and Sarna-Wojcicki, A.M. 1983. Distribution, thickness, and mass of late Pleistocene and Holocene tephra from major volcanoes in the northwestern United States: A preliminary assessment of hazards from volcanic ejecta to nuclear reactors in the Pacific northwest. U.S. Geological Survey Miscellaneous Field Studies, Map MF$1435,27 \mathrm{p}$.

Simkin, T. and Siebert, L. 2000. Earth's volcanoes and eruptions: an overview. In Encyclopedia of volcanoes. Edited by H. Sigurdsson, B. Houghton, S.R. McNutt, H. Rymer, J. Stix, and R.D. Ballard. Academic Press, San Diego, pp. 249-261.

Siebert, L. and Simkin, T. 2002-. Volcanoes of the world: an illustrated catalog of Holocene volcanoes and their eruptions. Smithsonian Institution, Global Volcanism Program Digital Information Series, GVP-3. Retrieved April 16, 2003, from http://www.volcano.si.edu/world/.

Simkin, T. and Fiske, R.S. 1983. Krakatau 1883: the volcanic eruption and its effects. Smithsonian Institution Press: Washington, D.C.

Skulski, T. 1988. The origin and setting of anomalous arc magmatism in the Wrangell volcanic belt, southwestern Yukon. Yukon Geology, 2: 88-98.

Skulski, T. and Francis, D. 1986. On the geology of the Tertiary Wrangell lavas in the St. Clare province, St. Elias mountains, Yukon. Yukon Geology, 1: 161-170.

Skulski, T., Francis, D. and Ludden, J. 1992. Volcanism in an arc-transform transition zone: the stratigraphy of the St. Clare Creek volcanic field, Wrangell volcanic belt, Yukon, Canada. Canadian Journal of Earth Sciences, 29: 446-461.

Skulski, T., Francis, D. and Ludden, J. 1991. Arc-transform magmatism in the Wrangell volcanic belt. Geology, 19: 11-14.

Smith, G.A. 1987. The influence of explosive volcanism on fluvial sedimentation: the 
Deschutes formation (Neogene) in central Oregon. Journal of Sedimentary Petrology, 57: 613-629.

Smith, N.D. 1971. Pseudo-planar cross-stratification produced by very low amplitude sand waves. Journal of Sedimentary Petrology, 41: 69-73.

Smith, R.C.M. 1991a. Landscape response to a major ignimbrite eruption, Taupo volcanic centre, New Zealand. In Sedimentation in volcanic settings. Edited by R.V. Fisher and G.A. Smith. Society for Sedimentary Geology (SEPM) Special Publication 45, United States of America, pp. 123-137.

Smith, R.C.M. 1991b. Post-eruption sedimentation on the margin of a caldera lake, Taupo volcanic centre, New Zealand. Sedimentary Geology, 74: 89-138.

Sneed, E.D. and Folk, R.L. 1958. Pebbles in the lower Colorado River, Texas, a study in particle morphogenesis. Journal of Geology, 66: 114-150.

Sohn, Y.K. and Chough, S.K. 1989. Depositional processes of the Suwolbong tuff ring, Cheju Island (Korea). Sedimentology, 36: 837-855.

Souther, J.G. 1970. Recent volcanism and its influence on early native cultures of northwestern British Columbia. In Early man and environments in northwest North America. Edited by R.A. Smith and J.W. Smith. Students Press, Calgary, Alberta, pp.5364.

Sparks, R.S.J. and Walker, G.P.L. (1977). The significance of vitric-enriched air-fall ashes associated with crystal-enriched ignimbrites. Journal of Volcanology and Geothermal Research, 2: 329-341.

Spector, S. 2002. Biogeographic crossroads as priority areas for biodiversity conservation. Conservation Biology, 16: 1480-1487.

Spooner, I., Osborn, G. and Groot, A. 1996. Resident oral histories: a tool for the study of recent environmental change on the Stikine plateau of northwestern British Columbia. In Geomorphic hazards. Edited by O. Slaymaker. John Wiley and Sons Ltd, England, pp.9-28.

Stasiuk, M.V., Hickson, C.J., and Mulder, T. 2003. The vulnerability of Canada to volcanic hazards. In An assessment of natural hazards and disasters in Canada. Edited by D. Etkin, C.E. Haque, and G.R. Brooks. Kluwer Academic Publishers, Dordrecht, pp.563-589.

Statistics Canada. 2005. Yukon monthly statistic review (July 2005). Government of Yukon: Whitehorse. Retrieved September 18, 2005 from the Yukon Bureau of Statistics, http://www.eco.gov.yk.ca/stats/monthy/rev012007.pdf. 
Steenblik, J.W. 1990. Volcanic ash- A rain of terra. Airplane Pilot: 9-15.

Stephens, C.D., Fogleman, K.A., Lahr, J.C. and Page, R.A. 1984. Wrangell-Benioff zone, southern Alaska. Geology, 12: 373-376.

Stuiver, M., Borns, H.W., Jr. and Denton, G.H. 1964. Age of a widespread layer of volcanic ash in the southwestern Yukon Territory. Arctic, 17: 259-261.

Switzer, D. n.d. Unpublished undergraduate thesis, Carleton University, Ottawa, Ontario, Canada.

Tagborn, W.V. and Lettenmaier, D.P. 1982. The impact of Mount St. Helens ash deposition on snowmelt. In Mount St. Helens: One year later. Edited by S.A.C. Keller. Eastern Washington University Press, Spokane, pp. 63-69.

Tanguy, J-C. 1994. The 1902-1905 eruptions of Montagne Pelée, Martinique: anatomy and retrospection. Journal of Volcanology and Geothermal Research, 60: 87-107.

Thouret, J.C. 1990. Effects of the 13 November 1985 eruption on the ice cap and snow pack of Nevado del Ruiz, Colombia. Journal of Volcanology and Geothermal Research, 41: $177-201$.

Tilling, R.I. and Lipman, P.W. 1993. Lessons in reducing volcano risk. Nature, 364: $277-280$.

Tilling, R.I., Topinka, L., and Swanson, D.A. 1990. Eruptions of Mount St. Helens: Past, present, and future. United States Geological Survey Special Interest Publication.

Torres, R.C., Self, S., and Martinez, Ma.M.L. 1996. Secondary pyroclastic flows from the June 15, 1991, ignimbrite of Mount Pinatubo. In Fire and mud: eruptions and lahars of Mount Pinatubo, Philippines. Edited by C.G. Newhall and R.S. Punongbayan.

Philippine Institute of Volcanology and Seismology and University of Washington Press, Quezon City, Philippines and Seattle, pp. 665-680.

Trabant, D.C., Waitt, R.B., Jr. and Major, J.J. 1994. Disruption of Drift glacier and origin of floods during the 1989-1990 eruptions of Redoubt volcano, Alaska. Journal of Volcanology and Geothermal Research, 62: 369-385.

Tuck, B.H. and Huskey, L. 1992. The economic consequences of the 1989-90 Mount Redoubt eruptions. Institute of Social and Economic Research, University of Alaska, Anchorage.

Tuck, B.H. and Huskey, L. 1994. Economic disruptions by Redoubt volcano: Assessment methodology and anecdotal empirical evidence. In Volcanic ash and 
aviation safety: Proceedings of the first international symposium on volcanic ash and aviation safety. Edited by T.J. Casadevall. U.S. Geological Survey Bulletin 2047.

Tucker, M.E. 1991. Sedimentary petrology: an introduction to the origin of sedimentary rocks (2nd edition). Blackwell Scientific Publications: London.

Tunbridge, I.P. 1981. Sandy high-energy flood sedimentation- some criteria for recognition, with an example from the Devonian of SW England. Sedimentary Geology, 28: 79-95.

Umbal, J.V. and Rodolfo, K.S. 1996. The 1991 lahars of southwestern Mount Pinatubo and evolution of the lahar-dammed Mapanuepe lake. In Fire and mud: Eruptions and lahars of Mount Pinatubo, Philippines. Edited by C.G. Newhall and R.S. Punongbayan. Philippine Institute of Volcanology and Seismology and University of Washington Press, Quezon City, Philippines and Seattle, pp.951-970.

United States Census Bureau. 2000. Census 2000 Summary File (SF 1) 100-Percent Data. Retrieved September 2005, from http://factfinder.census.gov/home/saff/main.html? lang=en.

United States Department of the Interior. 1974. Final Environmental Statement. WrangellSt. Elias National Park, Alaska. Alaska Planning Group, Anchorage, Alaska.

Venzke, E., Wunderman, R.W., McClelland, L., Simkin, T., Luhr, J.F., Siebert, L. and Mayberry, G. 2002-. (eds.). Global volcanism, 1968 to the present. Smithsonian Institution, Global Volcanism Program Digital Information Series, GVP-4. Retrieved April 2, 2003 from http://www.volcano.si.edu/gvp/reports/.

Viereck, L.A. 1968. Botanical dating of recent glacial activity in western North America. In Arctic and alpine environments. Edited by W.H. Osburn and H.E. Wright. Indiana University Press, Bloomington, pp. 89-204.

von Huene, R., Fisher, M.A., and Bruns, T.R. 1979. Continental margins of the Gulf of Alaska and late Cenozoic tectonic plate boundaries. In Proceedings of the $6^{\text {th }}$ Alaska Geological Society Symposium. Edited by A. Sisson. Alaska Geological Society, Anchorage, pp.11-130.

Waitt, R.B., Jr. 1989. Swift snowmelt and floods (lahars) caused by great pyroclastic surge at Mount St. Helens volcano, Washington, 18 May 1980. Bulletin of Volcanology, 52: 138-157.

Waitt, R.B., Jr., Gardner, C.A., Pierson, T.C., Major, J.J. and Neal, C.A. 1994. Unusual ice diamicts emplaced during the December 15, 1989 eruption of Redoubt volcano, Alaska. Journal of Volcanology and Geothermal Research, 62: 409-428.

Waitt, R.B., Mastin, L.G., and Begét, J.E. 1995. Volcanic-hazard zonation for Glacier 
Peak volcano, Washington. Open-File Report 95-499, Cascade Volcano Observatory, Vancouver, Washington.

Waitt, R.B., Jr., Pierson, T.C., MacLeod, N.S., Janda, R.J., Voight, B. and Holcomb, R.T. 1983. Eruption-triggered avalanche, flood, and lahar at Mount St. Helens: Effects of winter snowpack. Science: 221, 1394-1397.

Walker, G.P.L. 1972. Crystal concentration in ignimbrites. Contributions to Mineralogy and Petrology, 36: 135-146.

Walker, G.P.L. 1981. Plinian eruptions and their products. Bulletin of Volcanology, 44(2): 223-240.

Walker, G.P.L. and Croasdale, R. 1971. Two plinian-type deposits in the Azores. Journal of the Geological Society of London, 127: 17-55.

Warrick, R.A. 1975. Volcano hazard in the United States: A research assessment. Institute of Behavioural Science, University of Colorado, Boulder, Colorado.

Warrick, R.A. 1979. Volcanoes as hazard: An overview. In Volcanic activity and human ecology. Edited by P.D. Sheets and D.K. Grayson. Academic Press Inc., New York, p.161-194.

Warrick, R.A., Anderson, J., Downing, T., Lyons, J., Ressler, J., Warrick, M., Warrick, T. 1981. Four communities under ash after Mount St. Helens. Program on

Technology, Environment, and Man Mongraph \#34, Institute of Behavioural Science, University of Colrado, Boulder, Colorado.

Waythomas, C.F., Dorava, J.M., Miller, T.P., Neal, C.A., and McGimsey, R.G. 1998. Preliminary volcano-hazard assessment for Redoubt volcano, Alaska. Open-File Report 97-857, Alaska Volcano Observatory, Anchorage.

Waythomas, C.F. and Nye, C.J. 2002. Preliminary volcano-hazard assessment for Mount Spurr volcano, Alaska. U.S. Geological Survey, Open File Report 01-482.

Waythomas, C.F. and Waitt, R.B. 1998. Preliminary volcano-hazard assessment for Augustine Volcano, Alaska. U.S. Geological Survey Open File Report 98-0106.

Waythomas, C.F. and Wallace, K.L. 2002. Flank collapse at Mount Wrangell, Alaska, recorded by volcanic mass-flow deposits in the Copper River lowland. Canadian Journal of Earth Sciences, 39: 1257-1279.

Weeks, D.P. 2003. Wrangell-St. Elias National Park and Preserve, Alaska. Water Resources Scoping Report. Water Resources Division, National Park Service, Department of the United States Interior, Washington. 
West, K.D. and Donaldson, J.A. 2000. Evidence for winter eruption of the White River Ash (eastern lobe), Yukon Territory, Canada. Geocanada 2000 - The Millennium Geoscience Summit, Conference CD.

West, K.D. and Donaldson, J.A. 2002. Resedimentation of the late Holocene White River tephra, Yukon Territory and Alaska. In Yukon Exploration and Geology. Edited by D.S Emond, L.H. Weston, and L.L. Lewis. Exploration and Geological Services Division, Yukon Region, Indian \& Northern Affairs, Canada, pp.239-247.

West, K.D. and Donaldson, J.A. In press. White River ash. Yukon Geological Survey, Department of Energy, Mines, and Resources Educational Brochure 2006-7.

White, G.F. 1980. It did happen here. Natural Hazards Observer, 5: 1-2.

White, J.D.L., Houghton, B.F., Hodgson, K.A. and Wilson, C.J.N. 1997. Delayed sedimentary response to the A.D. 1886 eruption of Tarawera, New Zealand. Geology, 25: 459-462.

Wickstrom, R.D. 1980. Living waters. In Kluane: Pinnacle of the Yukon. Edited by J.B.Theberge. Doubleday Canada Limited, Toronto, Ontario.

Wilcox, R.E. 1959. Some effects of recent volcanic ash with special reference to Alaska. United States Geological Survey Bulletin 1028-N, 409-476.

Winkler, G.R. 2000. A geologic guide to Wrangell-St. Elias National Park and Preserve, Alaska. U.S. Geological Survey Professional Paper 1616.

Wissmar, R.C., McKnight, D.M., and Dahm, C.N. 1990. Contributions of organic acids to alkalinity in lakes within the blast zone of Mount St. Helens, Washington. Limnology and Oceanography, 35: 535-542.

Wood, D.M. and del Moral, R. 1987. Mechanism of early primary succession in subalpine habitat on Mount St. Helens. Ecology, 68: 780-790.

Wood, D.M. and Morris, W.F. 1990. Ecological constraints to seedling establishment on the pumice plains, Mount St. Helens, Washington. American Journal of Botany 77: 1411-1418.

Workman, W.B. 1974. The cultural significance of a volcanic ash which fell in the upper Yukon basin about 1400 years ago. In International conference on the prehistory and and paleoecology of western North American arctic and subarctic. Edited by S. Raymond and P. Schledermann. Archaeological Association of the University of Calgary, Alberta, pp.239-261. 
Workman, W.B. 1979. The significance of volcanism in the prehistory of subarctic northwest North America. In Volcanic activity and human ecology. Edited by P. Sheets and D.K. Grayson. Academic Press, New York, pp.339-371.

Yukon River Inter-Tribal Watershed Council. 2002. Yukon River Unified Watershed Assessment. Alaska Region Office, Anchorage, U.S.A. Retrieved August 31, 2005 from http://www.yritwc.com/Project/UnifiedWatershedAssessment.pdf.

Zanasi, L. 2005. Kluane national park and reserve economic impact analysis: Summary report. Retrieved August 21, 2005 from http://www.yukonomics.ca/reports/KNPR EIA SUMMARY.PDF.

Zarmati, L. 2005. Heinemann ancient and medieval history: Pompeii and Herculaneum. Harcourt Education, Australia.

Zhang, T., Barry, R.G., and Armstrong, R. 2001. Distribution of frozen ground in the northern hemisphere. American Geophysical Union Fall Meeting Abstracts: A702.

Zielinski, G.A. 1995. Stratospheric loading and optical depth estimates of explosive volcanism over the last 2100 years derived from the Greenland Ice Sheet Project 2 ice core. Journal of Geophysical Research, 100: 20,937-20,955. 